Guilhermo Almeida dos Reis

\title{
Centrando a Arquitetura de Informação no usuário
}

Dissertação apresentada à Escola de Comunicação e Artes da Universidade de São Paulo para obtenção do título de Mestre em Ciência da Informação.

Área de concentração: Cultura e Informação.

Orientadora: Profa. Dra. Sueli Mara Soares Pinto Ferreira 
Reis, Guilhermo Almeida dos

R375c Centrando a Arquitetura de Informação no usuário /

Guilhermo Almeida dos Reis. -- São Paulo : G. A. Reis, 2007. $250 \mathrm{p}$.

Dissertação (Mestrado) - Escola de Comunicações e Artes / USP, 2007.

Orientador: Prof ${ }^{a}$. Dr ${ }^{\text {a. }}$. Sueli Mara Soares Pinto Ferreira. Bibliografia

$\begin{array}{ll}\text { 1. Arquitetura da informação 2. Websites - Design } & \text { 2. }\end{array}$

3. Websites - Usabilidade 4. Design Centrado no Usuário

5. Interação homem-computador 6 . Sense-making

I. Ferreira, Sueli Mara Soares Pinto II. Título.

CDD 21.ed. - 004.2 


\section{Folha de Aprovação}

Guilhermo Almeida dos Reis

Centrando a Arquitetura de Informação no usuário

Dissertação apresentada à Escola de Comunicação e Artes da Universidade de São Paulo para obtenção do título de Mestre em Ciência da Informação.

Área de concentração: Cultura e Informação.

Aprovado em:

\section{Banca Examinadora}

Prof. Dr.

Instituição: Assinatura:

Prof. Dr.

Instituição: Assinatura:

Prof. Dr. Instituição: Assinatura: 
Para Eliza, que buscou sua felicidade muito além dos campos de algodão.

Para Clarice, que sempre teve a felicidade a sua frente, na máquina de costura.

E para Priscilla, que me ensinou que a felicidade está em viver essa dicotomia. 


\section{Agradecimentos}

A Deus, que sempre nos surpreende quando compreendemos um pouco mais a sua criação.

A minha mãe, por me despertar o gosto pelos estudos e por me ensinar a me importar com o próximo.

Ao meu pai, que me despertou a paixão pelos computadores e me aconselha em tudo.

A Mylene Melly, que me iluminou novos caminhos e acreditou que eu podia percorrê-los.

A Sueli Mara Ferreira, por me mostrar uma nova visão do mundo, pela paciência e pela orientação que dedicou a esse trabalho.

A Simone Weitzel, pela sua hospitalidade e por me ajudar com as entrevistas no Rio de Janeiro.

A minha esposa Priscilla, pelo amor, apoio, as exaustivas revisões e pela paciência,

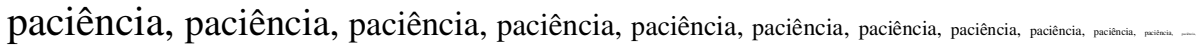

Ao Eduardo, que me mostra porque vale evoluir.

E aos meus familiares, amigos e a todos que me apoiaram e colaboraram para a realização desse trabalho. 


\section{REIS, Guilhermo Almeida dos. Centrando a Arquitetura de Informação no usuário.}

São Paulo, 2007. Dissertação (Mestrado) - Escola de Comunicação e Artes, Universidade de São Paulo.

\section{Resumo}

O presente trabalho analisa as metodologias de projeto de arquitetura de informação de websites sob o foco das abordagens de Design Centrado no Usuário da Ciência da Informação e da Interação Humano-Computador.

A metodologia adotada foi uma revisão da literatura, para formular um quadro de referência para análise das metodologias de projetos de arquitetura de informação, e duas pesquisas de campo. A primeira pesquisa foi quantitativa, baseada em um questionário online, e teve por objetivo levantar o perfil do arquiteto de informação das listas de discussões brasileiras. A segunda pesquisa foi qualitativa e seguiu a abordagem do Sensemaking, tendo como objetivo levantar as dificuldades, técnicas e metodologias encontradas nos projetos de arquitetura de informação de websites.

Como resultado da revisão da literatura foi formulado um quadro de referência composto de cinco fases (Pesquisa, Concepção, Especificação, Implementação e Avaliação). Os princípios das abordagens de Design Centrado no Usuário são aplicados nas duas fases iniciais, sendo que na primeira é aplicada a abordagem da Ciência da Informação, e na segunda a abordagem da Interação Humano-Computador.

A primeira pesquisa de campo retratou um profissional jovem, que vive nos grandes centros metropolitanos, com formação predominante na área de Humanas e que desenvolveu seus conhecimentos sobre Arquitetura de Informação de maneira autodidata. Quase metade deles não segue qualquer metodologia nos seus projetos e, entre os que seguem, a maioria utiliza uma metodologia própria.

A segunda pesquisa mostrou que os arquitetos de informação experientes adotam uma metodologia nos seus projetos e dedicam mais atenção às três primeiras fases do quadro de referência (Pesquisa, Concepção e Especificação). As metodologias vistas na 
prática não seguem a abordagem de Design Centrado no Usuário da Ciência da Informação, pois raramente são feitas pesquisas com usuários. Com relação à abordagem da Interação Humano-Computador, ela é pouco seguida porque os contratantes desconhecem a importância dos testes de usabilidade e porque os arquitetos não dominam as técnicas desses testes mais adequadas à Arquitetura de Informação. Com relação às dificuldades enfrentadas nos projetos, foram identificados três focos: o contratante, o próprio trabalho de Arquitetura de Informação e o contexto tecnológico em que o website está inserido, sendo o primeiro o mais citado.

Conclui-se que as metodologias de projetos de arquitetura de informação precisam evoluir na adoção das abordagens de Design Centrado no Usuário, para que consigam produzir websites que satisfaçam plenamente as necessidades dos usuários, e nas formas de avaliar os resultados, para verificar se os objetivos dos projetos foram plenamente alcançados.

Palavras-chave: Arquitetura da informação, Websites - Design, Websites - Usabilidade, Design Centrado no Usuário, Interação homem-computador, Sense-making. 
REIS, Guilhermo Almeida dos. Centering the Information Architecture in the user.

São Paulo, 2007. Dissertation (Master in Information Science) - Escola de Comunicação e Artes, Universidade de São Paulo.

\section{Abstract}

The study analyzes information architecture projects methodologies of websites under the focus of User Centered Design approaches of Information Science and HumanComputer Interaction .

The adopted methodology included a literature review, to formulate a theoric model to analyze information architecture project methodologies, and two empirical researches. The first one was a quantitative research, based on an on-line questionnaire which aimed at mapping the profile of information architects in Brazilian discussion lists. The second one was a qualitative research, in which the Sense-making approach was applied to map the difficulties, techniques and methodologies found in information architecture projects of websites.

As result the revision of literature review a theoric model with five phases was formulated (Research, Conception, Specification, Implementation and Evaluation) in which the approaches of User Centered Design should be applied in the two initial phases, in the first one should be applied the approach of Information Science and in the second one the approach of Human-Computer Interaction.

The first research showed a young professional, that lives in the great metropolitan centers, which is often graduated in Human area and developed their knowledge of Information Architecture in an autodidactic way. Almost half of them doesn't follow any methodology in their projects and, most of the ones that follow uses theirs own methodology.

The second research showed that seniors information architects adopt a methodology in theirs project and they dedicate more attention to the first three phases of the theoric model (Research, Conception and Specification). The methodologies found in 
practice don't follow the User Centered Design approach of Information Science, because they rarely make researches with users. The Human-Computer Interaction approach is little following because the clients are not convinced of the importance of usability tests and because information architects don't really know the techniques of usability tests more appropriate to information architecture projects. It were identified three focuses of difficulties faced in the projects: the clients, the own work of Information Architecture and the technology context in that the websites is inserted.

It concludes that the methodologies of information architecture projects need to increase in the adoption of User Centered Design, to produce websites that fully satisfy the users, and in ways to evaluate the results of the projects, to verify if its objectives had been reached.

Key-words: Information Architecture, Web Design, Websites - Usability, User Center Design, Human-Computer Interaction, Sense-making. 


\section{REIS, Guilhermo Almeida dos. Centré l' Architecture d' Information à l'utilisateur.}

São Paulo, 2007. Dissertation (Maître) - Escola de Comunicação e Artes, Universidade de São Paulo.

\section{Résumé}

Le travail présent analyse les méthodologies de projets d'architecture d'information des site Web sous le centre des approches de Design centré à l'Utilisateur de la Science de l'Information et de l'interaction de l' homme-machine.

La méthodologie adoptée a été une révision de la littérature, à fin de formuler un tableau de référence pour faire l'analyse des méthodologies, et deux recherches. La première recherche a été quantitative et basé sur un questionnaire connecté avec l'objectif d' identifier le profil l'architecte d'information des listes de discussions brésiliennes, et la deuxième recherche a été qualitatif, dans le lequel l'approche de Sense-Making a été appliquée pour identifier les difficultés, techniques et méthodologies trouvé dans les projets d'architecture d'information des site Web.

Le résultat de la révision de la littérature a été um tableau de la référence composé de cinq phases (Recherche, Conception, Spécification, Mise en oeuvre et Évaluation) dans lequel les principes des approches de Design centrés à l'Utilisateur devraient être appliqués dans les deux phases débutants, dans la première phase ils devraient être appliqués à l'approche de la Science de l'Information et dans le deuxième phase l'approche de l' interaction de l' homme-machine.

La première recherche a montré un jeune professionnel qui vie dans les grands centres métropolitains, avec formation prédominante des sciences humaines et qu'il a développé leur connaissance sur Architecture d'Information dans un chemin autodidacte. Presque demi d'eux ne suit pas toute méthodologie dans leurs projets et, parmi ceux qu'ils le font, la plupart des usages utilise une propre méthodologie.

La deuxième recherche a montré que les architectes expérimentés d'information adoptent une méthodologie dans ses projets et ils consacrent plus d'attention aux premières 
trois phases de l'image de la référence (Recherche, Conception et Spécification). Les méthodologies vues ne suivent pas l'approche de Design centré à l'Utilisateur de la Science de l'Information, parce que rarement des recherches avec les utilisateurs sont faites. Concernant l' approche de l'interaction homme-machine, elle est très peu suivi parce que les contractant partis ne connaissent pas de l'importance de l'usage teste et les architectes ne dominent pas les techniques de ceux tests plus appropriées à l'Architecture d'Information. Par rapport aux difficultés trouvées dans les projets ont été identifiées trois points focaux: le contractant parti, le propre travail d'Architecture d'Information et le contexte technologique où les site Web sont insérés, en étant le premier le plus mentionné.

Il a conclu que les méthodologies de projets d'architecture de besoin de l'information pour développer dans l'adoption des approches de Design centrées à l'Utilisateur á fin de qu'ils réussissent à produire des site Web pour satisfaire complètement les utilisateurs.

Mots-clés : Architecture d'information, Websites - Design, Websites - Utilisabilité, Design Centré à l'Utilisateur, Interaction l'homme - machine, Sense-making. 


\section{Sumário}

1.1 Objetivos da Pesquisa 28

1.1.1 Objetivo Geral 28

1.1.2 Objetivos Específicos 28

1.2 Justificativa 28

1.3 Metodologia 29

1.3.1 Revisão da Literatura 29

1.3.2 Levantamento do perfil do arquiteto de informação das listas de discussão brasileiras $\quad 30$

1.3.2.1 Variáveis de estudo 30

1.3.2.2 Amostragem 32

1.3.2.3 Coleta de Dados 33

1.3.2.4 Análise dos dados coletados 34

1.3.3 Levantamento das dificuldades, técnicas e metodologias encontradas nos projetos de arquitetura de informação de websites $\quad 34$

1.3.3.1 Amostragem 39

1.3.3.2 Coleta de Dados $\quad 40$

1.3.3.3 Análise dos dados coletados $\quad 42$

Capítulo 2 Design Centrado no Usuário $\quad 45$

2.1 O Design Centrado no Usuário na Interação Humano-Computador 49

2.2 O Design Centrado no Usuário na Ciência da Informação 53

2.3 Síntese 58

Capítulo 3 Arquitetura de Informação de websites 59

3.1 O que é Arquitetura de Informação de websites?

3.1.1 Um exemplo 66

3.1.2 Por que a Arquitetura de Informação é importante? 67

3.1.3 A multi-disciplinariedade da Arquitetura de Informação 69

3.2 Os componentes da arquitetura de informação para a Web 71

3.2.1 Sistema de Organização 73

3.2.1.1 O que é categorizar?

3.2.1.2 Dificuldades para organizar informação na Web 79 
3.2.1.2.1 Ambigüidade $\quad 80$

3.2.1.2.2 Heterogeneidade $\quad 80$

3.2.1.2.3 Diferenças de Perspectiva $\quad 81$

3.2.1.2.4 Políticas internas $\quad 82$

$\begin{array}{lll}3.2 .1 .2 .5 & \text { Estética } & 83\end{array}$

3.2.1.3 Esquemas de organização da informação $\quad 83$

3.2.2 Sistema de Navegação 86

3.2.2.1 Por que as pessoas se perdem ao navegar em um hipertexto? 87

3.2.2.1.1 Esquemas ou modelos de ambientes genéricos 87

3.2.2.1.2 Mapas espaciais cognitivos $\quad 88$

3.2.2.2 Dificuldades em projetar o sistema de navegação 90

3.2.2.3 Flexibilidade X Confusão 93

3.2.2.4 Navegação Social $\quad 93$

3.2.2.5 Elementos do Sistema de Navegação 94

3.2.3 Sistema de Rotulação $\quad 98$

3.2.3.1 O que são rótulos? 99

3.2.3.2 Dificuldades no projeto do sistema de rotulação 101

3.2.3.2.1 Conseguir falar na linguagem do usuário 101

3.2.3.2.2 Superar a ausência de feedback 102

3.2.3.2.3 Eliminar ambigüidades 102

3.2.3.2.4 Manter a consistência 103

3.2.3.3 A padronização dos rótulos 105

$\begin{array}{ll}\text { 3.2.3.4 Ícones como rótulos } & 105\end{array}$

Capítulo 4 Investigação teórica das metodologias de projetos de arquitetura de informação de websites

4.1 Princípios para metodologias de projeto de arquitetura de informação de websites

4.2 Análise das metodologias de projeto de arquitetura de informação de websites

4.2.1 A fase de Pesquisa 123

$\begin{array}{lll}\text { 4.2.1.1 Variáveis de pesquisa } & 124\end{array}$

4.2.1.1.1 Grupo de variáveis de pesquisa sobre a empresa 125

$\begin{array}{lll}\text { 4.2.1.1.2 } & \text { Grupo de variáveis de pesquisa sobre o usuário } & 128\end{array}$

4.2.1.2 Técnicas empregadas na fase de Pesquisa 130

4.2.1.2.1 Técnicas para pesquisa do grupo de variáveis sobre a empresa 130

4.2.1.2.2 Técnicas para pesquisa do grupo de variáveis sobre o usuário 131

4.2.2 A fase de Concepção 134

$\begin{array}{lll}\text { 4.2.2.1 Técnicas da fase de Concepção } & 138\end{array}$ 
4.2.2.1.1 Técnicas para a definição dos conceitos 138

4.2.2.1.2 Técnicas para a avaliação dos conceitos 141

4.2.3 A fase de Especificação 143

4.2.3.1 Sitegrama e Fluxo das Transações 145

4.2.3.2 Wireframe 146

$\begin{array}{llr}\text { 4.2.3.3 Vocabulário Controlado } & 148\end{array}$

4.2.4 A fase de Implementação $\quad 150$

4.2.5 A fase de Avaliação 152

$\begin{array}{lll}4.3 & \text { Síntese } & 154\end{array}$

Capítulo 5 Investigação empírica da metodologia de projetos de arquitetura de informação de websites

5.1 Resultado do levantamento do perfil do arquiteto de informação das listas de discussão brasileiras

5.1.1 Interesse em Arquitetura de Informação 158

$\begin{array}{lll}\text { 5.1.2 Perfil Demográfico } & 159\end{array}$

$\begin{array}{lll}5.1 .3 & \text { Escolaridade } & 161\end{array}$

5.1.4 Aprendizado de Arquitetura de Informação 166

$\begin{array}{lll}\text { 5.1.5 Grau de experiência } & 167\end{array}$

5.1.6 Empresas, cargos e forma de contratação 168

5.1.7 Atividades executadas 171

5.1.8 Existência de uma metodologia de projetos de arquitetura de informação $\quad 173$

5.1.9 Síntese dos resultados encontrados 175

5.2 Resultado do levantamento das dificuldades, técnicas e metodologias encontradas nos projetos de arquitetura de informação de websites 176

5.2.1 Análise da metodologia adotada pelos entrevistados 177

5.2.1.1 Análise das fases do quadro de referência na metodologia dos entrevistados 181

5.2.1.1.1 Análise da fase de Pesquisa na metodologia dos entrevistados 187

5.2.1.1.2 Análise da fase de Concepção na metodologia dos entrevistados 190

5.2.1.1.3 Análise da fase de Especificação na metodologia dos entrevistados 194

5.2.1.1.4 Análise da fase de Implementação na metodologia dos entrevistados 195

5.2.1.1.5 Análise da fase de Avaliação na metodologia dos entrevistados 196

5.2.2 Análise das dificuldades dos entrevistados nos projetos de arquitetura de
informação

$\begin{array}{ll}\text { 5.2.2.1 Análise das dificuldades dos entrevistados na fase de Pesquisa } & 201\end{array}$

5.2.2.2 Análise das dificuldades dos entrevistados na fase de Concepção 204

5.2.2.3 Análise das dificuldades dos entrevistados na fase de Especificação 210 
5.2.3 Síntese dos resultados encontrados

Capítulo 6 Considerações finais

Capítulo 7 Referências 


\section{Lista de Tabelas}

Tabela 1 - Principais listas de discussão brasileiras sobre Arquitetura de Informação__ 32

Tabela 2 - Categorias utilizadas para análise das metodologias dos entrevistados 44

Tabela 3 - Categorias utilizadas para análise das dificuldades enfrentadas pelos entrevistados 44

Tabela 4 - Problemas mais comuns nos websites (VIVIDENCE RESEARCH, 2001) _ 69

Tabela 5 - Elementos do Sistema de Navegação___ 94

Tabela 6 - Distribuição dos profissionais por estado e cidade de naturalidade e residência 160

Tabela 7 - Cursos de graduação, especialização e mestrado dos profissionais 163

Tabela 8 - Instituições de ensino citadas pelos profissionais 165

Tabela 9 - Outras formas como os profissionais desenvolveram seus conhecimentos _ 167

Tabela 10 - Distribuição dos profissionais por tipo de empresa 169

Tabela 11 - Tipo de empresa e forma de contratação dos profissionais 169

Tabela 12 - Nome dos cargos dos profissionais 170

Tabela 13 - Outras atividades relacionadas a Arquitetura de Informação citadas pelos profissionais 172

Tabela 14 - Classificação das outras atividades nas fases do quadro de referência 173

Tabela 15 - Características dos entrevistados 177

Tabela 16- Adoção de metodologia nos projetos de arquitetura de informação pelos entrevistados 181

Tabela 17 - Análise da fase de Pesquisa nas metodologias dos entrevistados 189

Tabela 18- Análise da fase de Concepção nas metodologia dos entrevistados 193

Tabela 19 - Análise da fase de Especificação nas metodologias dos entrevistados 195

Tabela 20 - Análise da fase de Implementação nas metodologias dos entrevistados 196

Tabela 21 - Análise da fase de Avaliação nas metodologias dos entrevistados 197

Tabela 22 - Dificuldades dos entrevistados nos projetos de arquitetura de informação _ 198 
Tabela 23 - Classificação das dificuldades pelo foco das questões dos entrevistados 199

Tabela 24 - Classificação das dificuldades nas fases do quadro de referência 200

Tabela 25 - Classificação das dificuldades nas fases do quadro de referência e pelo foco das questões dos entrevistados 200

Tabela 26 - Análise das dificuldades dos entrevistados na fase de Pesquisa 204

Tabela 27 - Análise das dificuldades dos entrevistados na fase de Concepção 209

Tabela 28 - Análise das dificuldades dos entrevistados na fase de Pesquisa 213

Tabela 29 - Classificação das estratégias pelo foco das questões dos entrevistados 215 


\section{Lista de Figuras}

Figura 1 - O Triângulo Sense-Making - adaptada de FERREIRA (1997) e CHEUK (1999) 37

Figura 2 - Mapas da linha de trem Yamanote em Tóquio (WURMAN, 1991) 67

Figura 3 - Disciplinas que colaboram na formação do corpo teórico da Arquitetura de Informação (ROSENFELD, 2001) 70

Figura 4 - Esquemas de organização da Informação 85

Figura 5 - Etapas do projeto de um website (MELLY, 2003) 109

Figura 6 - Metodologias de projetos de arquitetura de informação de websites 118

Figura 7 - Análise das metodologias nas fases do quadro de referência 122

Figura 8 - Atividades que compõem a fase de Concepção 137

Figura 9 - Metodologia de projetos de arquitetura de informação do entrevistado 1 182

Figura 10 - Metodologia de projetos de arquitetura de informação do entrevistado 2 _ 183

Figura 11 - Metodologia de projetos de arquitetura de informação do entrevistado 3 _ 184

Figura 12 - Metodologia de projetos de arquitetura de informação do entrevistado 4 _ 185

Figura 13 - Metodologia de projetos de arquitetura de informação do entrevistado 5 _ 186

Figura 14 - Questionário on-line - Instruções para o preenchimento 242

Figura 15 - Questionário on-line - Perguntas comuns a todos os entrevistados 242

Figura 16 - Questionário on-line - Perguntas exclusivas aos profissionais 243 


\section{Lista de Gráficos}

Gráfico 1 - Quantidade de mensagens postadas nas principais listas de discussão brasileiras sobre Arquitetura de Informação (janeiro a junho - 2006) 33

Gráfico 2 - Interesse dos entrevistados sobre Arquitetura de Informação 158

Gráfico 3 - Distribuição dos entrevistados por sexo e interesse 159

Gráfico 4 - Distribuição dos profissionais por sexo e faixa de idade 159

Gráfico 5 - Distribuição dos profissionais por sexo e estado civil 160

Gráfico 6 - Grau de instrução dos profissionais 161

Gráfico 7 - Área de formação dos profissionais 162

Gráfico 8 - Área de formação dos profissionais: Graduação x Pós-Graduação 164

Gráfico 9 - Formas como os profissionais desenvolveram seus conhecimentos sobre Arquitetura de Informação 166

Gráfico 10 - Distribuição dos profissionais pelos anos de trabalho com Internet 167

Gráfico 11 - Distribuição dos profissionais pelos anos de trabalho com Arquitetura de Informação 168

Gráfico 12 - Porcentagem do tempo de trabalho dedicado à Arquitetura de Informação 168

Gráfico 13 - Distribuição dos profissionais por tipo de cargo e tempo de dedicação a Arquitetura de Informação 170

Gráfico 14 - Atividades de Arquitetura de Informação que os profissionais já fizeram 171

Gráfico 15 - Quantidade de profissionais que seguem uma metodologia nos projetos de arquitetura de informação 174

Gráfico 16 - Metodologia adotada nos projetos de arquitetura de informação 174 
Cinco exabytes (5.000.000.000.000.000.000 bytes) de informação nova foram produzidos no mundo em 2002! Para se ter uma idéia do que isso significa imagine que um byte equivale a uma letra em uma página datilografada. Cinco exabytes equivalem então a uma pilha de livros que vai do Sol a Plutão. Se for dividida pela população da Terra, cabe a cada habitante uma pilha de livros com 8 metros de altura. E, ainda mais surpreendente, a quantidade de informação nova produzida no mundo cresce a uma taxa de $30 \%$ ao ano!

Estes dados, de um estudo da University of California at Berkeley (2003), retratam o fenômeno da explosão da produção e distribuição de informação que revoluciona o mundo no final do século passado e início deste novo. Nunca se produziu e se distribuiu tanta informação na história da humanidade. "Uma edição do The New York Times em um dia de semana contém mais informação do que o comum dos mortais poderia receber durante toda a vida na Inglaterra do século XVII" (WURMAN, 1991, pág. 36).

A Internet, a grande rede mundial de computadores, é o maior símbolo desse fenômeno. Conectando tudo e todos, esta rede é o meio de comunicação que mais rápido se expande na história, impregnando-se na vida da nossa sociedade contemporânea. Segundo pesquisa da NETCRAFT (2007) existem atualmente mais de 108 milhões de websites na 
Internet oferecendo seus serviços e conteúdos informativos a todo o mundo. CASTELLS (2003) cita que "A Internet é o tecido de nossas vidas neste momento. Não é futuro. É presente. Internet é um meio para tudo, que interage com o conjunto da sociedade e, de fato, apesar de tão recente em sua forma societária (...) não precisa de explicação, pois já sabemos o que é Internet".

Esta explosão da informação causa um visível desconforto na maioria das pessoas. Bombardeada por incontáveis notícias, artigos, e-mails, relatórios, filmes e websites a mente humana não consegue absorver toda a informação necessária à sobrevivência do trabalhador moderno. Esse excesso de informação gera a "síndrome da fadiga da informação". Batizada pelo psicólogo britânico Davis Lewis, é caracterizada por tensão, irritabilidade e sentimento de abandono causados pela sobrecarga de informação a que o ser humano está exposto (ANTUNES, 1998; SATO e HASHIMOTO, 2004).

Preocupado com a ansiedade que a informação provoca, Richard Wurman presidiu, em 1976, a conferencia nacional do American Institute of Architects cujo tema era "The Architecture of Information". Nesta conferência foi proposta a criação de uma nova disciplina chamada de Arquitetura de Informação, para combater esse sentimento de ansiedade, resultado da distância entre o que compreendemos e o que deveríamos compreender. O objetivo da Arquitetura de Informação é organizar a informação de forma que seus usuários possam assimilá-la com facilidade.

A Arquitetura de Informação proposta por WURMAN começou baseada na mídia impressa, principalmente na produção de guias, mapas e atlas. Atualmente a área que mais vem sendo explorada por essa disciplina é a organização de websites.

Dentre os diversos tipos de problemas que podem afetar o uso de um website, chama a atenção os relacionados com a organização das suas informações. Falhas nessa organização provocam nos seus usuários confusão, frustração ou até mesmo a ira, dificultando o uso do website e repercutindo diretamente no retorno do investimento. ROSENFELD e MORVILLE (2002) citam que a incapacidade de encontrar uma informação é um dos fatores que mais desagradam os usuários, e pesquisas do NIELSEN NORMAN GROUP (2001) apontam que 27\% das causas de insucesso das vendas de um 
website de comércio eletrônico devem-se ao fato de que o usuário simplesmente não conseguiu encontrar o item que procurava.

No projeto de um website, a elaboração da arquitetura de informação é uma das etapas iniciais, sendo responsável por definir toda a organização, a estrutura do website sobre a qual as demais partes irão se apoiar (projeto gráfico, redação, programação, etc.). Erros nessa etapa inicial, se não forem observados e corrigidos de imediato podem ser difíceis e caros de corrigir nas etapas seguintes. PRESSMAN (1995, pág. 28) afirma a respeito do projeto de desenvolvimento de qualquer software (inclusive websites) que "uma mudança, quando solicitada tardiamente num projeto, pode ser mais do que a ordem de magnitude mais dispendiosa da mesma mudança solicitada nas fases iniciais."

Dessa forma aplicar uma metodologia aos projetos de arquitetura de informação de websites é de suma importância para evitar erros e minimizar riscos. MORROGH (2003, pág. 117) afirma que "se o processo para gerenciar o design de ambientes de informação não for explícito, as chances de falhas aumentam. Portanto, o gerenciamento do design de ambientes de informação é mais eficiente e efetivo quando segue um método".

A Arquitetura de Informação se propõe a organizar a informação para satisfazer às necessidades informacionais dos seus usuários. Para tanto duas disciplinas que estudam o design centrado no usuário podem auxiliar a melhorar a metodologia e a qualidade do produto final dos projetos de arquitetura de informação de websites: a Ciência da Informação e a Interação Humano-Computador. A Ciência da Informação colabora com seus estudos de usuários e necessidades de informação e pode auxiliar a compreendê-los melhor. Já a Interação Humano-Computador colabora com suas análises de usabilidade que possuem técnicas para validar com usuários a eficácia e eficiência das soluções. 


\subsection{Objetivos da Pesquisa}

\subsubsection{Objetivo Geral}

Estudar as práticas de projetos de arquitetura de informação de websites com profissionais brasileiros que atuam na área para verificar o grau de aderência das metodologias de projetos dessa natureza com as propostas teóricas.

\subsubsection{Objetivos Específicos}

1- Realizar um estudo bibliográfico sobre as dificuldades e as metodologias de projetos de arquitetura de informação de websites.

2- Analisar a forma de trabalho dos arquitetos de informação no Brasil para descobrir suas dificuldades e quais metodologias e técnicas utilizam para superá-las.

\subsection{Justificativa}

A Arquitetura de Informação de websites ainda é um campo novo. Existe pouca teoria e raros congressos internacionais sobre o mesmo, e no Brasil o assunto é pouco tratado no meio acadêmico. Porém já é grande a procura sobre o tema pelos profissionais.

$\mathrm{Na}$ Web o crescimento explosivo da informação não está sendo acompanhado da melhora dos métodos para organizar as informações por ela apresentada. São poucos os autores que tratam o tema com profundidade científica.

Ferramentas para identificar e localizar informação relevante não cresceram em efetividade na mesma taxa explosiva que a quantidade de informação disponível. Consequentemente, nossa habilidade para encontrar, revisar e usar informação é limitada e também contribui para os sentimentos de sobrecarga de informação. Desenvolver ferramentas de gerenciamento de informação que sejam fáceis de usar e mais sofisticadas é um fato importante para ajudar a aliviar o problema da sobrecarga da informação. (MORROGH, 2003, pág. 99) 
Dessa forma, esse trabalho se justifica ao contribuir para a consolidação de uma metodologia de projetos de arquitetura de informação de websites e assim auxiliar na conceituação teórica que o tema necessita. Pretende-se também que ele auxilie no desenvolvimento e melhora dos métodos de organização da informação específicos para o ambiente Web.

\subsection{Metodologia}

O objetivo desse trabalho é investigar as dificuldades, técnicas e metodologias empregadas na prática pelos arquitetos de informação brasileiros e confrontá-las com as recomendações teóricas para avaliar sua aplicabilidade. Para tanto foram realizadas uma revisão da literatura e duas pesquisas de campo

\subsubsection{Revisão da Literatura}

O objetivo da revisão da literatura foi compreender o que é Arquitetura de Informação de websites, as dificuldades dos projetos de arquitetura de informação e as metodologias existentes tendo como foco o Design Centrado no Usuário nas visões de Ciência da Informação e da Interação Humano-Computador. Essa revisão foi respaldada em autores consagrados sobre esses temas.

Especialmente no caso da Arquitetura de Informação, devido à pouca literatura existente, fez parte dessa revisão artigos publicados em websites destinados a profissionais da área. Como a literatura disponível em língua portuguesa sobre o tema é escassa e restrita a artigos técnicos, foram consultados autores estrangeiros, especialmente os norteamericanos, onde o tema está mais difundido. O período pesquisado foram os últimos 11 anos (1995 a 2006), que abrangem desde os primeiros trabalhos de aplicação dos conceitos de Arquitetura de Informação ao design de websites.

Como resultado, essa revisão de literatura caracterizou o que é Arquitetura de Informação e quais os seus componentes, identificou as metodologias de projetos existentes e as comparou de modo a produzir um quadro de referência para análise das pesquisas de campo. 


\subsubsection{Levantamento do perfil do arquiteto de informação das listas de discussão brasileiras}

A primeira pesquisa de campo teve como objetivo levantar o perfil sóciodemográfico dos arquitetos de informação e o grau de experiência desses profissionais. Ela também teve a função de identificar e selecionar arquitetos de informação experientes para participarem da segunda pesquisa.

Foi necessário realizar essa pesquisa porque não foram encontrados dados sóciodemográficos traçando o perfil da população dos profissionais que trabalham com Arquitetura de Informação de websites no Brasil que permitisse identificar uma amostra para a segunda pesquisa. Por se tratar de um campo novo de trabalho, provavelmente ainda não existam muitas informações disponíveis sobre o perfil desses profissionais.

A pesquisa foi realizada com membros de listas de discussão brasileiras sobre Arquitetura de Informação, nas quais estão presentes tanto arquitetos de informação quanto pessoas interessadas no tema. A coleta de dados foi feita por meio de um método quantitativo utilizando um questionário on-line.

\subsubsection{Variáveis de estudo}

As variáveis de estudo dessa pesquisa de levantamento do perfil dos arquitetos de informação foram divididas nos seguintes grupos:

- Interesse em Arquitetura de Informação: busca evidenciar se o foco do entrevistado é voltado para pesquisa (atividade acadêmica, desenvolvimento profissional, etc.) ou para atividade profissional (atua como profissional no desenvolvimento de projetos de arquitetura de informação de websites). $\mathrm{O}$ grupo de entrevistados que manifestou interesse em atividade profissional foi denominado "profissionais". Os entrevistados puderam manifestar os dois interesses.

- Perfil Demográfico: mostra as características básicas dos entrevistados: sexo, idade, estado civil, naturalidade e residência. 
- Escolaridade: descreve a formação acadêmica dos entrevistados: grau de instrução, nome dos cursos acadêmicos realizados, área de formação e instituição de ensino. Esse grupo de variáveis foi pesquisado apenas com os profissionais.

- Aprendizado de Arquitetura de Informação: indica a forma com que os profissionais desenvolveram seus conhecimentos sobre Arquitetura de Informação.

- Grau de experiência: aponta os anos de trabalho do profissional na área e a sua dedicação à Arquitetura de Informação.

- Empresas, cargos e forma de contratação: descreve o tipo de empresa onde os profissionais trabalham, seus cargos e a relação trabalhista que possuem.

- Atividades executadas: mostra quais das atividades relacionadas à Arquitetura de Informação os profissionais já desenvolveram.

- Existência de uma metodologia de projetos de Arquitetura de Informação: indica a adoção de uma metodologia por parte dos entrevistados nos seus projetos de Arquitetura de Informação.

O Anexo I desse trabalho mostra como as questões do questionário on-line se relacionaram com as variáveis descritas acima. 


\subsubsection{Amostragem}

A amostra foi composta pelos participantes das principais listas de discussão brasileiras sobre Arquitetura de Informação ${ }^{1}$. A Tabela 1 mostra essas listas.

Tabela 1 - Principais listas de discussão brasileiras sobre Arquitetura de Informação

\begin{tabular}{|c|c|c|c|}
\hline Lista de discussão & AlflA-pt & Arquitetura de Informação & Arquitetura de Informação (BR) \\
\hline Descrição & $\begin{array}{l}\text { Debate assuntos relacionados ao } \\
\text { campo de estudo da Arquitetura de } \\
\text { Informação e à profissão de } \\
\text { arquiteto de informação. }\end{array}$ & $\begin{array}{l}\text { Discute a Arquitetura de } \\
\text { Informação e a profissão de } \\
\text { arquiteto de informação no Brasil. } \\
\text { Hospedada no website Orkut } \\
\text { (www.orkut.com). }\end{array}$ & $\begin{array}{l}\text { Discute a Arquitetura de } \\
\text { Informação. } \\
\text { Também hospedada no website } \\
\text { Orkut (www.orkut.com). }\end{array}$ \\
\hline $\begin{array}{l}\text { Quantidade de } \\
\text { membros } \\
\text { em junho/2006 } \\
\end{array}$ & 370 & 1865 & 923 \\
\hline URL & $\begin{array}{l}\text { http://lists.ibiblio.org/mailman/listinf } \\
\text { o/aifia-pt }\end{array}$ & $\begin{array}{l}\text { http://www.orkut.com/Community.a } \\
\text { spx?cmm }=38740\end{array}$ & $\begin{array}{l}\text { http://www.orkut.com/Community.a } \\
\text { spx?cmm }=48720\end{array}$ \\
\hline
\end{tabular}

Uma análise dessas comunidades mostra que existe um percentual elevado de pessoas que pertencem a todas elas. Dois fatores levam a essa conclusão:

- As duas comunidades hospedadas no Orkut possuem muitos tópicos idênticos, postados pelos mesmos usuários.

- A comunidade Arquitetura de Informação hospedada no Orkut incentiva, na sua descrição, seus membros a participarem da lista de discussão AIfIA-pt.

Apesar de ter poucos membros, a quantidade de mensagens postadas na lista de discussão AIfIA-pt é significativamente maior que as outras listas, como mostra o Gráfico 1. Assim sua comunidade foi a população alvo dessa pesquisa, ou seja, o universo pesquisado foram seus 370 membros.

\footnotetext{
${ }^{1}$ Foi postada uma mensagem na comunidade AifIA-pt indagando aos seus membros se conheciam outras listas de discussão brasileiras sobre Arquitetura de Informação além das três investigadas nessa pesquisa. Ninguém citou outra lista com essa característica.
} 
Gráfico 1 - Quantidade de mensagens postadas nas principais listas de discussão brasileiras sobre Arquitetura de Informação (janeiro a junho - 2006)

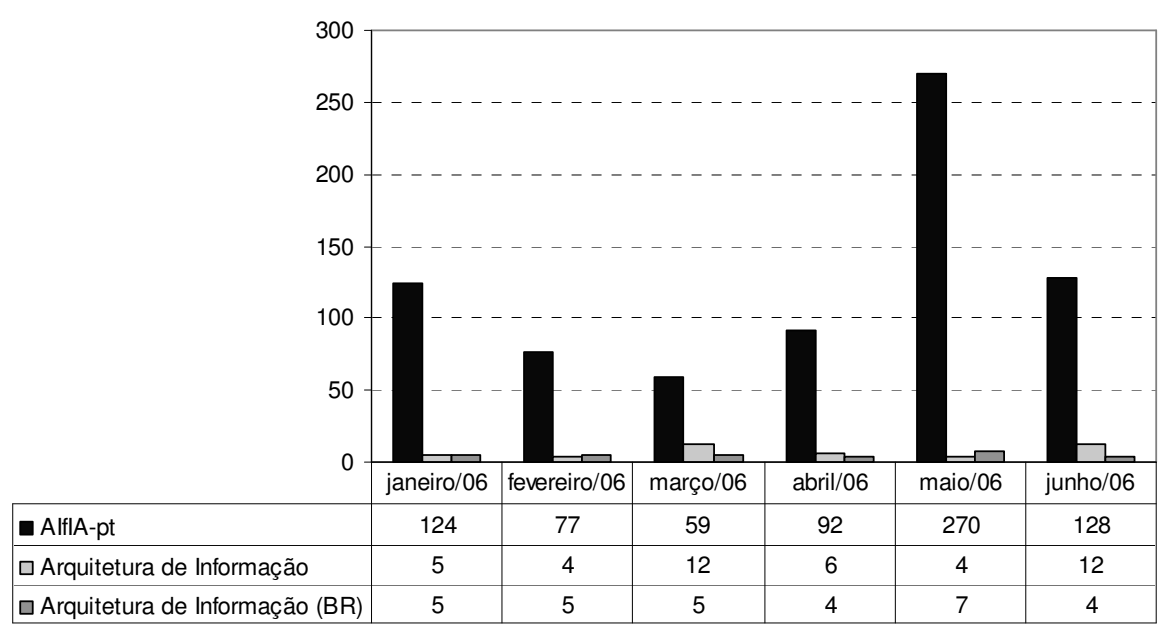

\subsubsection{Coleta de Dados}

A coleta de dados foi realizada por meio de um questionário on-line disponibilizado na Web. A escolha desse instrumento de pesquisa foi decorrente das suas vantagens intrínsecas, que, segundo GIL (1999), são:

- Possibilidade de atingir grande número de pessoas, mesmo que estejam geograficamente dispersas.

- Baixo custo de pessoal.

- Conveniência para o entrevistado responder o questionário no momento e local que julgar mais apropriado.

- Não exposição dos entrevistados à influência das opiniões e do aspecto pessoal do entrevistador.

Optou-se por divulgar o questionário de forma on-line porque a Web faz parte do cotidiano dos arquitetos de informação, público alvo dessa pesquisa.

O questionário foi composto na sua maior parte de questões fechadas, o que facilitou sua tabulação. Questões abertas foram utilizadas apenas para o entrevistado esclarecer sua resposta, caso não encontrasse uma opção que o atendesse. Para verificar a eficiência desse instrumento de pesquisa foi realizado um pré-teste com dois membros das 
listas de discussão para verificar a compreensão das questões. Os devidos ajustes foram feitos no questionário e a versão utilizada na pesquisa está apresentada no Anexo I.

Todos os membros das três comunidades citadas foram convidados a participar da pesquisa. O primeiro convite foi feito através da postagem de uma mensagem nas três comunidades convidando seus membros a participarem. Como questionários não oferecem garantias de que a maioria das pessoas o responderá (GIL, 1999), foram feitos dois outros convites por e-mail no decorrer da pesquisa apenas aos membros da AIfIA-pt que ainda não haviam respondido a pesquisa porque essa é a única comunidade que divulga o endereço de e-mail dos seus participantes.

\subsubsection{Análise dos dados coletados}

Os dados obtidos com as questões fechadas da pesquisa foram analisados segundo fórmulas estatísticas simples como média, porcentagem e histogramas para se quantificar as respostas e levantar correlações entre as variáveis pesquisadas. Foram empregadas planilhas eletrônicas para produzir as tabelas e os gráficos utilizados na análise.

Para as questões abertas, as respostas foram classificadas e a quantidade de citações de cada categoria foi quantificada. Como nas questões fechadas, foram elaborados gráficos e tabelas para análise. Os resultados dessa pesquisa estão apresentados no capítulo 5.

\subsubsection{Levantamento das dificuldades, técnicas e metodologias encontradas nos projetos de arquitetura de informação de websites}

O objetivo da segunda pesquisa de campo foi conhecer as dificuldades, técnicas e as metodologias vivenciadas pelos arquitetos de informação brasileiros durante um projeto da arquitetura de informação de um website e avaliar a aplicação na prática do quadro de referência proposto na investigação teórica. Pretendeu-se com essa pesquisa avaliar se os problemas e recomendações teóricas dos diversos autores levantados na revisão da literatura são aplicados na prática do dia-a-dia.

Para realizá-la foi utilizada a técnica de pesquisa qualitativa de entrevistas em profundidade derivada da abordagem do Sense-Making, que se destina a estudar as 
necessidades de informação que os usuários enfrentam em uma determinada situação e como fazem para superá-la.

A escolha de uma metodologia qualitativa foi adotada porque o objetivo dessa pesquisa foi conhecer em detalhes as dificuldades que os arquitetos de informação enfrentam nos seus projetos e quais técnicas utilizam para superá-las. Foi escolhida a abordagem do Sense-Making porque:

- Permite recriar com riqueza de detalhes a situação na qual ocorreu a dificuldade.

- Utiliza as próprias palavras do entrevistado para explicar o significado de cada situação.

- É uma metodologia utilizada com sucesso nas áreas de Biblioteconomia e Ciência da Informação.

A abordagem do Sense-Making utilizada nessa pesquisa começou a ser desenvolvida pela Profa. Dra. Brenda Dervin e colegas em 1972 na Ohio State University, nos Estados Unidos, e somente em 1983 foi publicado o primeiro documento contento toda a sua base filosófica, conceitual, teórica e metodológica. (FERREIRA, 1997).

Tradicionalmente a abordagem do Sense-Making tem sido vastamente aplicada em questões de pesquisas relacionadas com o uso de informação e de sistemas de informação por seres humanos. Ela não é apenas um modelo de busca de informação, é também um modelo de metodologia para estudar busca e uso da informação (WILSON apud CHEUK e DERVIN, 1999) e que consiste em "um conjunto de premissas conceituais e teóricas e um conjunto de metodologias relacionadas para avaliar como as pessoas criam sentido dos seus mundos e como elas usam a informação e outros recursos nesse processo" (DERVIN e NILAN, 1986, pág. 20). Sua função é entender como as pessoas satisfazem suas necessidades de informação e esse conhecimento pode ser aplicado no design dos sistemas de informação tornando-os mais eficazes (DERVIN, 1997).

Essa abordagem pode também ser usada num sentido ainda mais amplo. Segundo DERVIN (1992, pág. 67) "a abordagem metodológica que é chamada de Sense-Making é 
uma abordagem para estudar a construção que os seres humanos fazem para criar sentido de suas experiências".

FERREIRA (1997, pág. 17) resume da seguinte forma os pressupostos básicos que embasam a abordagem do Sense-Making:

a) a realidade não é completa nem constante, ao contrário é permeada de descontinuidades fundamentais e difusas, intituladas “vazios” (gaps). Assume-se que esta condição é generalizável porque as coisas na realidade não são conectadas e estão mudando constantemente.

b) a informação não é algo que exista independentemente e externamente ao ser humano, ao contrário é um produto da observação humana.

c) desde que se considera a produção de informação ser guiada internamente, então o Sense-Making assume que toda informação é subjetiva.

d) busca e uso da informação são vistas como atividades construtivistas, como criação pessoal do sentido do ser humano.

e) focaliza em como indivíduos usam as observações tanto de outras pessoas como as próprias para construir seus quadros da realidade e os usa para direcionar seu comportamento.

f) o comportamento dos indivíduos pode ser prognosticado com mais sucesso com a estruturação de um modelo que focalize mais suas situações de mudança do que atributos denominados características de personalidades ou demográficas.

g) pesquisa por padrões, observando mais do que assumindo conexões entre situações e necessidades de informação, entre informação e uso.

h) considera-se a existência de compreensões universais da realidade que permitem prognósticos e explicações melhores do que seria possível obter nas abordagens positivistas tradicionais ${ }^{2}$.

\footnotetext{
${ }^{2}$ Grifos da autora.
} 
$\mathrm{Na}$ abordagem do Sense-Making a informação é, segundo DERVIN apud FERREIRA (1997, pág. 18), "aquilo que informa", ou seja, o que ajuda o indivíduo a superar os obstáculos no seu caminho, buscando novos conhecimentos, quando seu quadro de referências interno, não consegue resolvê-lo. Surge então uma necessidade de informação e sua solução é obtida pela informação.

Metaforicamente é como se o indivíduo estivesse se movendo sempre em frente, caminhando através do espaço-tempo. De repente ocorre-lhe uma situação onde seu conhecimento não é capaz de superar o obstáculo que aparece na sua frente devido a lacunas no seu quadro de referências interno provocando a necessidade de informação. Para transpor este obstáculo e atingir seu objetivo o indivíduo precisa adquirir um novo conhecimento e para tanto ele planeja e executa uma estratégia de busca de informação. Ao encontrar a informação, ele a utiliza solucionando seu problema (DERVIN 1992). Esta metáfora, chamada de Triângulo do Sense-Making é ilustrada na Figura 1.

Figura 1 - O Triângulo Sense-Making - adaptada de FERREIRA (1997) e CHEUK (1999)

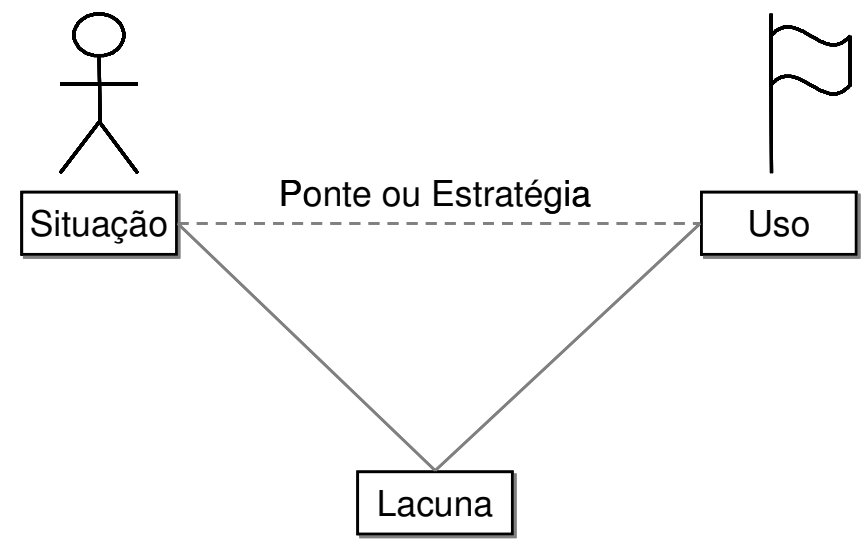

O Triangulo do Sense-Making ilustra bem todos os elementos que reunidos determinam o quadro de um estudo de necessidades de informação:

- Situação: Descreve o contexto espacial e temporal no qual ocorre a necessidade de informação. É o momento em que o indivíduo "pára de caminhar" porque seu senso interno se esgotou e um novo senso precisa ser criado. 
- Lacuna: Trata-se da dúvida do indivíduo, da questão propriamente dita. É a falta de compreensão (conhecimento) ou a compreensão parcial de algo que o obrigou a "parar".

- Uso: É a ação que o indivíduo pretende executar empregando o conhecimento que necessita.

- Ponte ou Estratégia: É o caminho cognitivo e construtivista percorrido pelo indivíduo para encontrar a informação que necessita transpondo a lacuna.

Analisando individualmente as situações, características, pensamentos e ações de cada pessoa, um estudo na abordagem do Sense-Making tenta chegar a padrões comuns à maioria. Nota-se, que no aparente caos apresentado por um indivíduo em seu caminho cognitivo e construtivista, existe uma padronização que pode ser compartilhada com outros.

Vale observar que a metáfora do Sense-Making é apenas uma forma de ordenar o processo cognitivo dos seres humanos quando buscam uma informação.

É importante enfatizar que o Triangulo do Sense-Making é uma ferramenta metateórica altamente abstrata e não é assumido como uma fotografia da realidade. Ele não assume que toda criação de sentido (ex. buscando informação) é dotada de propósito e seja linear. Nem assume que a criação de sentido requer recursos além da própria pessoa, ou até o uso consciente de recursos. Apesar de que, ter propósito, linearidade e busca consciente é o que os pesquisadores esperam de um estudo de Sense-Making. (CHEUK, 1999)

A abordagem do Sense-Making foi escolhida como metodologia para essa pesquisa porque ela permite detectar quais são os problemas (lacunas) que os arquitetos de informação enfrentam em seus projetos (situações) e que procedimentos (estratégias) utilizam para superá-los. 


\subsubsection{Amostragem}

Dentre os 93 entrevistados que responderam ao questionário on-line, 5 profissionais compuseram a amostra da pesquisa de levantamento das dificuldades, técnicas e metodologias encontradas em projetos de arquitetura de informações de websites. Foram selecionados aqueles com maior experiência, ou seja, com maior tempo de trabalho na área e que dedicam o maior percentual de seu tempo de trabalho a Arquitetura de Informação.

Segundo ALRECK e SETTLE (apud FERREIRA, 1995, pág. 86) "uma amostra aparentemente pequena é perfeitamente aceitável quando a pesquisa: (a) requer muito esforço do informante e produz volume relativamente grande de informação; (b) focalizar mais nos padrões estabelecidos entre as respostas do que nos itens observados individualmente". Como ambos os casos se aplicaram à técnica de coleta de dados desta pesquisa, considerou-se o tamanho da amostra suficiente.

Os seguintes critérios de seleção foram adotados para selecionar a amostra dessa pesquisa:

- Participantes que atuam como profissionais em projetos de arquitetura de informação: Como essa pesquisa visa compreender o trabalho dos profissionais foram selecionados apenas os entrevistados que declararam ter interesse profissional na área.

- Profissionais com naturalidade brasileira e residência no Brasil: O objetivo da pesquisa é compreender o trabalho dos arquitetos de informação brasileiros dentro da realidade brasileira.

- Profissionais com tempo de experiência de trabalho com Arquitetura de Informação acima da média (5 anos ou mais) e que dedicam mais de 50\% do seu tempo de trabalho à Arquitetura de Informação: Esse é o critério que definiu os arquitetos de informação experientes.

- Apenas um representante por empresa: Esse critério foi utilizado para que a amostra tivesse maior diversidade. Nos casos de empresas com mais 
de um profissional com condições de participar foi selecionado aquele que, pelo nome do seu cargo, possui uma função de coordenação ou gerência porque normalmente possui uma visão mais abrangente.

- A amostra precisa conter profissionais de mais de uma cidade: Para que a amostra não fosse regionalizada foram selecionados profissionais de São Paulo e do Rio de Janeiro, as cidades com maior concentração de entrevistados na pesquisa de levantamento do perfil dos arquitetos de informação das listas de discussão brasileiras. Nenhum profissional das outras cidades atendeu aos demais critérios.

\subsubsection{Coleta de Dados}

Para coletar os dados nessa pesquisa foram realizadas entrevistas em profundidade seguindo o roteiro apresentado no Anexo II e pré-testado. O roteiro inicia-se com algumas perguntas de identificação do entrevistado com o objetivo de criar empatia com ele, deixando-o a vontade para responder as questões das partes seguintes. Em seguida o roteiro apresenta várias questões divididas em três fases:

\section{- Fase I - Levantamento da metodologia}

O objetivo das questões dessa fase foi identificar se o entrevistado adota uma metodologia nos seus projetos de arquitetura de informação e descrevê-la criando um ambiente propício para as questões da segunda fase. Para tanto foi solicitado que ele descrevesse, utilizando cartões post-it, cada atividade que executa e a seqüência em que elas aparecem ao longo do projeto. Essa descrição foi feita livremente pelo entrevistado, sem inferências por parte do entrevistador.

\section{- Fase II - Análise das dificuldades de um projeto}

Nessa segunda fase do roteiro, o objetivo foi identificar as dificuldades que os entrevistados enfrentaram em um projeto real e como as superaram. Para isso foi utilizada a técnica de entrevistas de micro-momento da linha do tempo (micro-moment time line interview), um método qualitativo que permite reconstruir com detalhes todo o caminho 
percorrido pelo entrevistado ao enfrentar uma situação no tempo-espaço. Justifica-se esta escolha porque este é o método que melhor deriva dos conceitos teóricos da abordagem do Sense-Making (DERVIN, 1992).

Esta técnica é baseada em entrevistas individuais e solicita a cada entrevistado que descreva passo a passo tudo o que ocorreu em uma situação. Cada passo é analisado separadamente para determinar os componentes do triângulo do Sense-Making, que caracterizam a representação da necessidade de informação (a situação, a lacuna, o uso e a estratégia). Com essas questões é possível identificar a tentativa do entrevistado em buscar alguma informação, aprender algo, compreender melhor, ou fazer sentido da realidade.

No âmbito dessa pesquisa, a situação escolhida é um projeto de arquitetura de informação do qual o entrevistado participou e que seguiu todas as atividades da metodologia que descreveu na fase II. As lacunas foram as grandes dificuldades que enfrentou no decorrer do projeto. Os usos foram a importância de superar cada dificuldade na visão do entrevistado. As estratégias foram a maneira como o entrevistado superou a dificuldade e as facilidades que teve no decorrer do projeto.

O micro-momento da linha do tempo tem se mostrado uma técnica bastante versátil, já tendo sido aplicada a grande variedade de indivíduos em diferentes contextos, como usuários de bibliotecas ou de sistemas multimídia buscando informações, doadores de sangue em situação de doação, crianças e problemas de relacionamento com shows de TV, entre outros. (DERVIN, 1983; FERREIRA, 1995). A técnica também é versátil com relação à forma empregada para abordar os diferentes contextos vivenciados pelos indivíduos.

- Fase III - Comparação da metodologia do entrevistado com o quadro de referência proposto

$\mathrm{Na}$ terceira e última parte da pesquisa, o entrevistado foi convidado a retomar o desenho da sua metodologia feito na fase I da pesquisa e compará-lo com o quadro de referência formulado na investigação teórica por meio de perguntas com respostas estimuladas. 
No Anexo II está o roteiro da entrevista individual utilizado com as questões de cada uma das fases identificadas. Foram realizadas duas entrevistas em caráter de pré-teste para avaliar a compreensão do roteiro e a forma de aplicá-lo.

\subsubsection{Análise dos dados coletados}

As entrevistas com os arquitetos de informação foram filmadas e para analisá-las foi utilizada a técnica de análise de conteúdo.

Esta técnica de análise vem sendo progressivamente utilizada para codificar questõe de pesquisa abertas e descrever tendências em contextos de comunicação (AGARWAL apud FERREIRA, 1995). Ela também é sugerida por DERVIN (1992) para analisar as entrevistas da técnica do micro-momento da linha do tempo como uma forma de sistematizar os resultados e eliminar a subjetividade.

A análise de conteúdo é, segundo BARDIN (2000, pág. 42), “um conjunto de técnicas de análise das comunicações visando obter, por procedimentos sistemáticos e objetivos de descrição do conteúdo das mensagens, indicadores (quantitativos ou não) que permitam a inferência de conhecimentos relativos às condições de produção/recepção (variáveis inferidas) destas mensagens".

Trata-se de um processo no qual o material textual é analisado e categorizado conforme seu conteúdo e a partir desta categorização é possível fazer inferências respondendo as questões da pesquisa. A execução desse processo envolve três fases distintas: pré-análise, descrição analítica e interpretação inferencial.

$\mathrm{Na}$ fase de pré-análise todo o material a ser analisado é organizado com o objetivo de "tornar operacionais e sistematizar as idéias iniciais, de maneira a conduzir a um esquema preciso do desenvolvimento das operações sucessivas, num plano de análise" (BARDIN, 2000, pág. 95). Nessa fase escolhem-se os documentos que serão analisados, formulam-se os objetivos e hipóteses, definem-se os indicadores e prepara-se o material.

$\mathrm{Na}$ fase de descrição analítica submete-se o material a procedimentos de classificação e categorização executando-se as regras definidas na fase anterior 
(TRIVINÕS apud ABDALLA, 2003). Trata-se da fase mais longa de todo o processo porque envolve realizar muitas operações normalmente intelectuais.

Por fim na fase de interpretação inferencial os resultados brutos são tratados de maneira a serem significativos e válidos utilizando operações estatísticas. Neste momento o pesquisador pode propor inferências e interpretar os resultados conforme os objetivos e hipóteses previamente definidos (BARDIN, 2000).

No caso específico dessa pesquisa, a pré-análise consistiu em assistir os vídeos das entrevistas para transcrever suas principais partes, organizar as anotações realizadas durante a entrevista e registrar a metodologia de cada entrevistado desenhada com os cartões post-it.

$\mathrm{Na}$ descrição analítica as entrevistas foram analisadas visando identificar as situações, sentimentos, dificuldades e metodologias mencionadas para a criação de categorias de análise. Depois cada entrevista foi analisada em profundidade para classificála nessas categorias. Para facilitar a análise, as categorias foram organizadas em grupos baseados no quadro de referência.

A Tabela 2 mostra as categorias de análise referentes às fases I e III do roteiro da entrevista, seus grupos e as respectivas questões do roteiro que as originaram. Essas categorias foram utilizadas para analisar as metodologias dos entrevistados.

A Tabela 3 apresenta as categorias de análise referentes à fase II do roteiro da entrevista e também as respectivas questões do roteiro que as originaram. Essas categorias foram utilizadas para analisar as dificuldades enfrentadas pelos entrevistados nos seus projetos e estão divididas em grupos que correspondem aos componentes do triângulo do Sense-Making (situação, lacuna, uso e estratégia).

Por fim, a interpretação inferencial consistiu em avaliar a quantidade de citações das respostas dos entrevistados em cada categoria de análise, que foram organizadas em tabelas para interpretação. Como a amostra da pesquisa é pequena não foram realizadas análises estatísticas. 
Tabela 2 - Categorias utilizadas para análise das metodologias dos entrevistados

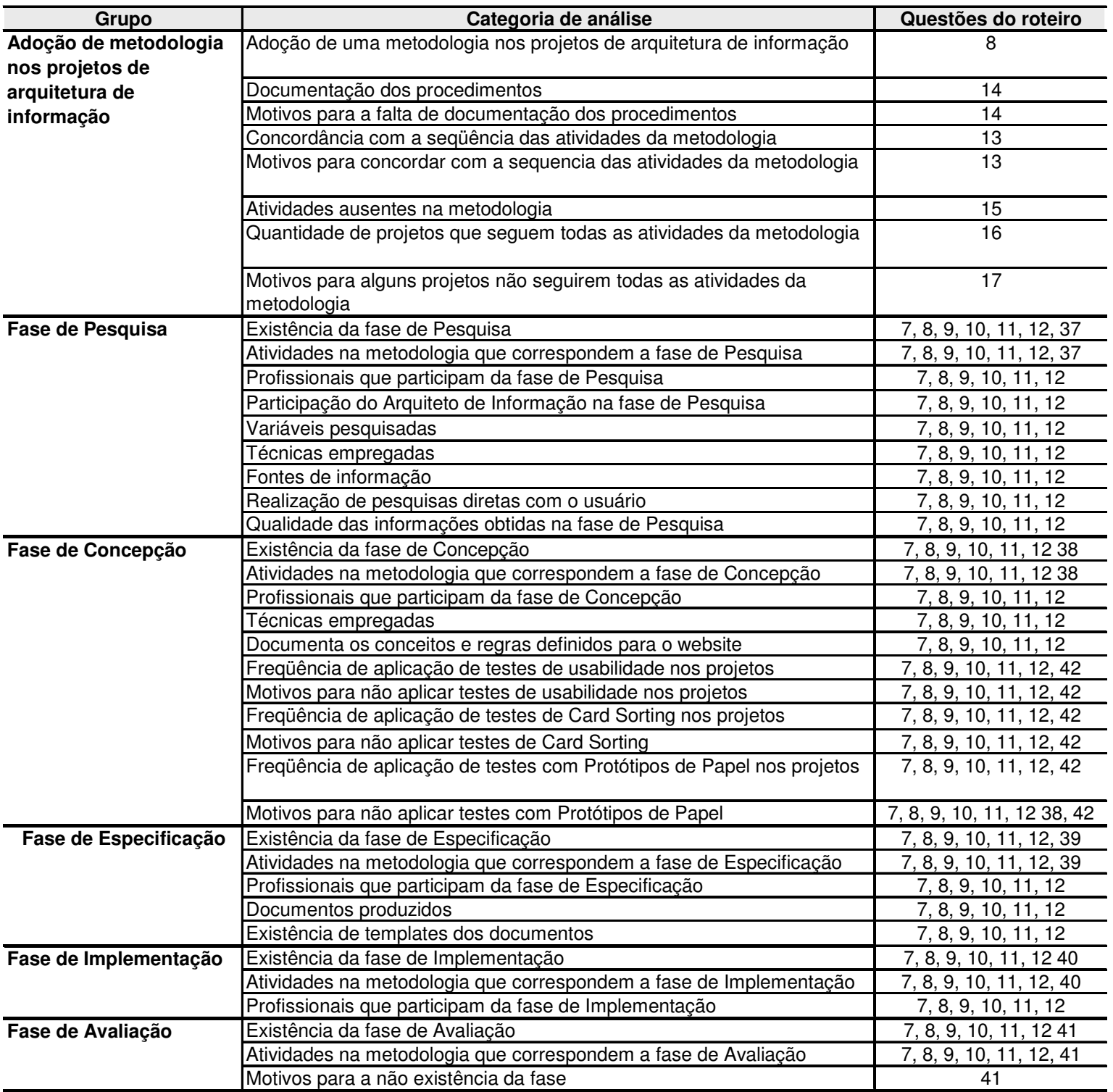

Tabela 3 - Categorias utilizadas para análise das dificuldades enfrentadas pelos entrevistados

\begin{tabular}{l|l|c}
\hline \multicolumn{1}{c|}{ Grupo } & \multicolumn{1}{c|}{ Categoria de análise } & Questões do roteiro \\
\hline \multirow{2}{*}{ Situação } & Fase no quadro de referência & $19,20,21$ \\
\cline { 2 - 3 } & Atividade em que ocorreu a dificuldade & $19,20,21$ \\
\hline \multirow{2}{*}{ Lacuna } & Dificuldade & $19,20,21$ \\
\cline { 2 - 3 } & lotivos que geraram a dificuldade & 22 \\
\cline { 2 - 3 } & Foco da questão & 21 \\
\hline \multirow{2}{*}{ Uso } & Importância de superar a dificuldade & 23 \\
\hline \multirow{2}{*}{ Estratégia } & Estratégia utilizada para superar a dificuldade & $26,27,28,33,35,36$ \\
\cline { 2 - 3 } & Grau de superação da dificuldade & 24,25 \\
\cline { 2 - 3 } & Satisfação do Entrevistado & 29,3 \\
\cline { 2 - 3 } & Satisfação do Contratante & 31,32 \\
\cline { 2 - 3 } & Expectativa do que ajudaria superar a dificuldade & 34 \\
\hline
\end{tabular}




\section{Design Centrado no Usuário}

Duas disciplinas, a Interação Humano-Computador e a Ciência da Informação, vêm, nas últimas décadas, aprofundando os estudos sobre usuários, suas necessidades, seus comportamentos e as tarefas que desempenham ao interagir com sistemas. Essas duas disciplinas desenvolveram abordagens diferentes, mas complementares, para o design de sistemas centrados no usuário, criando fundamentos teórico-metodológicos e diversas técnicas próprias.

Tanto a abordagem de Design Centrado no Usuário da Interação HumanoComputador quanto a da Ciência da Informação tem como princípio entender profundamente as necessidades do usuário para construir sistemas que as atendam plenamente. Assim conceituar necessidade é fundamental para compreender essas abordagens.

O conceito de necessidade remete tanto a autores da Ciência da Informação, que se referem a serviços e produtos de informação, como também de outras áreas, como a 
ciência do Marketing, que tem por objetivo maior descobrir e atender necessidades através da oferta e troca de produtos de valor (KOTLER, 1998).

Necessidade é um estado de ausência, de falta, um estado no qual alguém está carente de algo básico e inerente a sua condição de vida. KOTLER (1998, pág. 27) afirma que "necessidade humana é um estado de privação de alguma satisfação básica". Entendese por satisfação básica as exigências que surgem das situações ou condições de vida, como, por exemplo, alimento, vestuário, abrigo, segurança, sentimento de posse ou autoestima.

LINE (1974) conceitua necessidade como a informação que um indivíduo precisa ter, algo que irá favorecer sua pesquisa. Semelhante à definição do Marketing, é o que suprirá seu estado de privação.

Junto com o conceito de necessidade surge o conceito de cliente, que o Marketing define como o ser (pessoa, empresa, instituição, etc.) que está vivenciando um ou mais estados de privação e por isso possui uma ou mais necessidades.

É importante observar que uma necessidade nasce das características da condição de vida do cliente e por isso não pode ser criada por nenhuma entidade externa, como uma empresa que lança novos produtos (KOTLER, 1998). Os seres humanos, por exemplo, sempre tiveram a necessidade de se comunicar a longas distâncias porque vivem em comunidades geograficamente distantes. Atualmente isso é resolvido com telefones celulares, e-mails e diversas outras tecnologias de telecomunicações. Porém os seres humanos já utilizaram, para atender essa mesma necessidade, o telégrafo, o correio e até mesmo mensageiros a pé.

O objeto capaz de satisfazer a uma ou mais necessidades, como o celular no exemplo anterior, é definido como produto. Outros exemplos são um hambúrguer, uma calça, um hotel ou até mesmo uma igreja. É comum a idéia de que um produto está associado a um bem físico e tangível, porém essa é uma definição simplista do termo. Como o mais importante em um produto é a sua capacidade de atender as necessidades, existem inúmeros casos de produtos que não possuem um bem físico associado, como, por 
exemplo, uma agência de viagens ou um website. Neles o benefício é entregue e a necessidade é atendida sem que qualquer bem físico seja fornecido.

Segundo HOOLEY e SAUNDERS (1996, pág. 26) "os clientes não compram produtos; eles compram o que o produto faz por eles." Aos clientes interessa os benefícios que obtém do uso do produto e não as suas características físicas ou técnicas. KOTLER (1998, pág. 28) cita uma frase jocosa que ilustra bem a importância do benefício em um produto: "Um carpinteiro não compra uma furadeira; compra um furo".

Devido ao fato de que os benefícios vêm do uso do produto e não das suas características físicas, uma mesma necessidade pode ser atendida por uma infinidade de produtos, cada qual empregando uma tecnologia diferente na solução do mesmo problema. HOOLEY e SAUNDERS (1996) ilustram isso citando o exemplo de um jardineiro que deseja o gramado baixo. Ele pode comprar um cortador de grama ou sementes de uma espécie que não cresce. PORTER (1986) inclusive recomenda que as empresas apliquem esse olhar nos seus planejamentos estratégicos para descobrir produtos que possam substituir os que fabricam e assim encontrar concorrentes ocultos.

O próprio sentimento de satisfação do cliente com um produto vem dos benefícios que ele obtém com seu uso. Esse sentimento é resultante da diferença entre a expectativa do cliente e o desempenho percebido com o uso. Se o cliente tinha uma expectativa maior que o desempenho percebido fica insatisfeito, se sua expectativa era igual ao desempenho fica satisfeito e se o desempenho superar suas expectativas fica altamente satisfeito ou encantado (KOTLER, 1999).

Os únicos árbitros do grau de perfeição do atendimento proporcionado pela organização são os próprios clientes. A qualidade dos bens e serviços oferecidos no mercado será julgada pelos clientes com base no grau da qualidade de atendimento das suas necessidades e desejos. Do ponto de vista dos clientes, um produto ou serviço de qualidade é aquele que satisfaz a "adequação à finalidade", e não aquele que oferece um luxo desnecessário.

(HOOLEY e SAUNDERS, 1996, pág. 25) 
Uma maneira comumente utilizada para aumentar a satisfação do cliente é criar produtos que atendam a várias necessidades. Biscoitos vitaminados com alto valor nutritivo, margarinas que previnem doenças cardíacas e sabonetes com hidratantes são alguns exemplos de produtos que atendem mais necessidades que o seu propósito básico. A convergência de tecnologias em dispositivos móveis é outro exemplo. O telefone celular integrado com câmera fotográfica, filmadora, MP3 player e agenda eletrônica é outro exemplo de produto que atende a um amplo conjunto de necessidades e com isso aumenta a satisfação de seus clientes.

Outros dois conceitos importantes para se compreender o que é necessidade são desejo e demanda.

LINE (1974) define desejo como aquilo que o cliente gostaria de ter. Já KOTLER (1999) define desejo como a vontade do cliente em utilizar um produto específico e conhecido para atender as suas necessidades. Por exemplo, uma pessoa precisa de abrigo, segurança e status social (necessidades) e deseja uma casa de três dormitórios e duas vagas de garagem em um condomínio fechado (desejo). Os desejos são continuamente moldados por forças e instituições sociais. Devido ao seu caráter tangível, é comum os clientes manifestarem seus desejos e não suas necessidades.

Segundo KOTLER (1999), demanda é o desejo por um produto específico somado à vontade e capacidade de comprá-lo. Para LINE (1974) demanda é aquilo que o indivíduo manifesta querer, aquilo que ele solicita. Esse autor ainda acrescenta a definição de uso, como aquilo que o indivíduo realmente utiliza. Na definição desses dois autores existe uma relação causa-efeito, de forma que um uso é decorrente de uma demanda, de um desejo é derivado de uma necessidade.

Da vontade e capacidade de compra do cliente nascem os mercados e a relação custo-valor do produto. Custo é o quanto o cliente precisa dar em troca do produto, quanto paga por ele. Valor é a estimativa que o produto tem em satisfazer a um conjunto de necessidades. Quanto menor o custo e maior o valor, maior é a vontade do cliente em comprar o produto. 
Segundo ALMEIDA e OLIVEIRA (2002), o projeto bem sucedido de um website nasce do conhecimento profundo dos seus usuários (seus clientes) e das suas necessidades. Quanto maior o conjunto de necessidades que o website suprir, maior será a fidelização de seus usuários. Dessa forma as metodologias de projetos de arquitetura de informação precisam ter o mesmo olhar de quem está construindo um produto para atender às necessidades de seus clientes.

Foi da preocupação com as necessidades dos usuários que surgiram as abordagens de Design Centrado no Usuário tanto da Interação Humano-Computador quanto da Ciência da Informação, que estão apresentadas a seguir.

\subsection{O Design Centrado no Usuário na Interação Humano-Computador}

Nascida como um subconjunto das teorias de ergonometria e interface homemmáquina, as teorias sobre a Interação Humano-Computador (IHC) visam compreender como ocorre o diálogo entre homens e computadores. Sua preocupação central é a usabilidade das interfaces computacionais e, enquanto disciplina, ela se ocupa do design, avaliação e implementação de sistemas de computação interativos para uso humano e com o estudo dos principais fenômenos que cercam esses sistemas. (PREECE apud MARTINEZ, 2002).

O campo da Interação Humano-Computador começou a se desenvolver com o advento dos computadores pessoais nos anos 70, que reduziram drasticamente o custo dessas máquinas tornando-as muito mais acessíveis. Antes dessa década, os computadores eram muito mais caros que o custo das horas das pessoas que o operavam, o que restringia seu uso apenas a engenheiros, técnicos e cientistas especializados em Computação. A partir da década de 70, com a invenção do primeiro computador pessoal, e mais tarde, nos anos 80, com a invenção do mouse e das interfaces gráficas, os computadores se popularizaram passando a ser acessados por pessoas das mais diversas áreas de conhecimento. Para esses novos usuários, leigos em informática, os computadores precisaram se tornar mais simples e fáceis de usar, ou seja, com maior usabilidade (GARCIA, 2003). 
Usabilidade é conceito chave na Interação Humano-Computador. A norma ISO 9241-11 (apud USABILITY NET, 2003) a define como a capacidade na qual um produto pode ser usado por usuários específicos para alcançar objetivos específicos com efetividade, eficiência e satisfação num contexto específico de uso. É importante destacar a preocupação que a usabilidade tem em restringir sua medição para casos específicos de uso do sistema ("usuários específicos", "objetivos específicos”, "contexto específico de uso"). Se um sistema pretende atender qualquer usuário, com qualquer objetivo e em qualquer ambiente dificilmente conseguirá atender a todos com a mesma usabilidade. Segundo MARTINEZ (2002) para um mesmo usuário, o mesmo produto pode apresentar diferentes características de usabilidade quando utilizado em ambientes diferentes ou com objetivos diferentes.

Essa especificidade pode ser notada nos cinco atributos associados à usabilidade, distintos e por vezes conflitantes, definidos por NIELSEN (1993):

- Facilidade de aprendizagem: Capacidade com que um usuário começar a interagir rapidamente com o sistema logo na primeira vez que o utiliza.

- Eficiência de uso: Grau de produtividade atingido pelo usuário depois que aprendeu a utilizar o sistema.

- Facilidade de memorização: Retenção, capacidade do usuário de voltar a utilizar o sistema após certo tempo sem precisar aprendê-lo novamente.

- Baixa taxa de erros: Medida do quanto o usuário pode ser induzido ao erro pelo sistema e o quanto pode se recuperar do mesmo.

- Satisfação subjetiva: Medida do quanto o usuário se sente feliz de estar utilizando o sistema.

Normalmente não é possível privilegiar todos os atributos simultaneamente [refere-se a esses 5 atributos de NIELSEN]. Às vezes os atributos podem não ser compativeis, implicando em que se tenha que priorizar um deles em detrimento de outros. (...) Por isso, deve-se analisar o contexto do projeto e estabelecer os 
objetivos de usabilidade a serem atingidos ${ }^{3}$ e quais os atributos a serem priorizados. Assim, se estabelece uma ordem de prioridade para os atributos de modo a atender o público e a aplicação. (MARTINEZ, 2002, pág. 18)

Segundo MARCUS (2002) a melhoria da usabilidade em interfaces computacionais traz diversos benefícios como:

- Economia nos custos e nos tempos de desenvolvimento;

- Redução dos erros dos usuários e dos custos de manutenção, redesign, suporte (help-desk), treinamento e documentação;

- Aumento da satisfação do usuário, do volume de transações, das vendas, do tráfego, do tamanho da audiência, do market share, das taxas de sucesso, da eficiência e da produtividade;

- Retenção de clientes e atração de mais consumidores.

Na Web, objeto de estudo desse trabalho, a importância da usabilidade é maior que nos softwares tradicionais. NIELSEN (2000) explica que os usuários na Internet experimentam a usabilidade de um website antes de se comprometerem a usá-lo e a gastar seu dinheiro com ele. Ocorre que, se o usuário não se sentir satisfeito com a usabilidade do website, ele o abandona causando perda da receita financeira. No software tradicional isto não ocorre porque o usuário primeiro compra o software para depois utilizá-lo. Assim, o fabricante tem sua venda garantida mesmo em casos de insatisfação do cliente.

A preocupação com a construção de interfaces com alta usabilidade é o tema central da Interação Humano-Computador e é de onde surgem as principais críticas dessa disciplina aos processos de design tradicionais da Engenharia de Software, que são "principalmente orientados ao produto, com foco na funcionalidade do sistema, geralmente voltados ao desenvolvimento de grandes sistemas de software e oferecem pouca relação entre o designer e as necessidades do usuário" (MARTINEZ, 2002).

\footnotetext{
${ }^{3}$ Grifos da autora.
} 
A literatura de IHC é permeada por críticas contundentes ao modelo de implementação de interfaces existentes hoje, e à vitimização do usuário de sistemas interativos. As descrições da relação entre homem e computador encontradas em Cooper (1995, 1999), Norman (1990, 1993) e Nielsen (2000) são sempre dramáticas e ricas em exemplos da dificuldade existente em se interagir com os artefatos tecnológicos presentes no mundo, sejam eles maçanetas, relógios ou computadores propriamente ditos. (MARQUES, 2002, pág. 24)

Para atingir seus objetivos a Interação Humano-Computador desenvolveu fundamentos teórico-metodológicos para o design de interfaces computacionais centradas no usuário. RUBIN (apud MARTINEZ, 2002, pág. 20) aponta os três princípios básicos desses fundamentos:

1. Focalizar desde o começo no usuário e nas tarefas realizadas por ele, em um determinado ambiente (não adianta saber quais funções o software tem que executar sem saber quem é o usuário e porque precisaria dessas funções).

2. Medidas empíricas da usabilidade do produto observando a interação do usuário com ele (testes com usuários realizando tarefas representativas).

3. Utilizar um processo de design iterativo, com refinamentos sucessivos (onde o design pode ser modificado após as fases de prototipação ou testes), e análise de custo-benefício.

A partir desses princípios a Interação Humano-Computador desenvolveu e vem aprimorando metodologias para projetos de Engenharia de Software como o modelo estrela (HIX apud MARTINEZ, 2002) no qual todo o processo de design é centrado na avaliação da usabilidade, de modo que várias medições da eficiência e eficácia do uso do sistema para realizar as tarefas do usuário são feitas ao longo do projeto. Nessas metodologias, a avaliação da usabilidade é realizada em todas as fases do projeto e não apenas no final com o produto acabado como sugerem os processos de design tradicionais da Engenharia de Software. 
$\mathrm{Na}$ literatura são encontradas diversas recomendações de uso nos projetos de Arquitetura de Informação das técnicas de avaliações de usabilidade provenientes da Interação Humano-Computador (REISS, 2000; ROSENFELD e MORVILLE, 2002; DIJCK, 2003; SAPIENT apud MORROGH, 2003; WODTKE, 2003; BUSTAMANTE, 2004). As técnicas mais citadas por esses autores seguem a abordagem da Discount Usability de NIELSEN (1994) e estão detalhadas no capítulo 4.

Essa abordagem tem por objetivo reduzir o custo e o tempo de elaboração dos testes de usabilidade e, para tanto, emprega métodos qualitativos e baseados em três técnicas: avaliação heurística, construção de protótipos parciais para avaliar cenários e testes com o usuário "pensando em voz alta". A vantagem dessa abordagem é que suas técnicas permitem avaliar a usabilidade de uma interface computacional nas fases iniciais do projeto, como ocorre nos projetos de arquitetura de informação. Nesse momento poucos recursos foram investidos e a correção dos erros é mais simples.

\subsection{O Design Centrado no Usuário na Ciência da Informação}

Desde meados do século passado a Ciência da Informação vem aprimorando seus fundamentos teórico-metodológicos de forma a compreender melhor os padrões de comportamento de busca de informação dos seres humanos para elaborar o design de sistemas de informação de modo a fazer com que tais sistemas atendam melhor seus usuários.

Os estudos de usuários, necessidades e usos da informação da Ciência da Informação começaram no final da década de 1940 com a apresentação dos trabalhos de Bernal e Urquart, que procuravam compreender o modo como cientistas e técnicos buscavam informação e como utilizavam a literatura nas suas respectivas áreas. Desde então tais estudos tornaram-se um objeto recorrente nessa ciência buscando encontrar uma teoria e metodologia para suportá-los. SILVA e colab. (2002, pág. 132) citam que "a caracterização da necessidade de informação é um campo clássico da Ciência da Informação e da Biblioteconomia". Apesar de ser um campo muito estudado, essas autoras afirmam que ainda não existe consenso sobre a forma mais indicada para realizá-los. 
Esses estudos atravessaram uma mudança de paradigma ao longo dos últimos 60 anos. Segundo FERREIRA (1997), durante esse período os estudos de necessidade e uso da informação evoluíram de uma abordagem centrada no sistema para uma abordagem centrada no usuário, chamadas respectivamente de abordagem tradicional e abordagem alternativa. Essa mudança de paradigma nasceu da preocupação dos novos pesquisadores em compreender os aspectos cognitivos e comportamentais dos usuários quando estão buscando informação (DERVIN e NEGAM, 1986).

Segundo DERVIN e NILAN (1986), os estudos baseados na abordagem tradicional têm as seguintes características:

- A informação é vista como algo objetivo, com significado constante e que possui absoluta correspondência com a realidade.

- O usuário é um receptor passivo dessa informação objetiva. O papel dos sistemas de informação é disponibilizar pacotes informacionais nas mãos desse usuário. O usuário é um mero informante das características do sistema. As reais necessidades que o motivaram a buscar a informação e o uso que fará dela não são objetos de estudo.

- O objetivo desses estudos é encontrar mecanismos para descrever o comportamento do usuário de uma forma trans-situacional, ou seja, que se aplica idealmente a qualquer situação. Apenas as dimensões externas e os comportamentos são observados.

- As perguntas formuladas nesses estudos têm como foco o sistema de informação. Pesquisa-se quem o usa, quanto e como usa, mas não se pesquisa para que ele é usado. Variáveis demográficas e sociográficas são empregadas para descrever o uso desses sistemas, a satisfação do usuário e as barreiras ao seu acesso. As perguntas mais comuns são: "Quem usa?", "O que usa?", "Quando usa?”, "Onde usa?”.

- Utiliza-se técnicas quantitativas de pesquisa 
Para FERREIRA (1997, pág. 6), de acordo com as revisões publicadas pelo ARIST, os estudos da abordagem tradicional possuem os seguintes problemas teórico-metodológicos:

i. Falta uniformidade conceitual nas pesquisas, termos como informação, necessidade de informação e uso da informação tem sido utilizado indiscriminadamente;

ii. Faltam definições e pressupostos claros para focalizar variáveis e gerar questões de pesquisa e,

iii. Ausência de metodologias específicas, abrangentes e com rigor científico.

A partir da década de 70 surgiram críticas aos paradigmas da abordagem tradicional porque ela não considera as necessidades do usuário ao buscar a informação. Para o usuário, a informação é uma ferramenta que resolve seus problemas porque lhe transmite o conhecimento que lhe falta para realizar suas necessidades. Compreender estas necessidades é entender a causa que o motivou a buscar informações. WILSON (2000) confirma isto ao afirmar que uma pessoa começa um processo de busca de informação simplesmente para atender suas necessidades, que são motivadas por fatores fisiológicos, emocionais ou cognitivos, todos externos ao sistema de informação. Esse autor enfatiza essa visão construtivista da informação ao sugerir que o termo "necessidade de informação" seja substituído pelo termo "busca de informação para satisfazer necessidades".

Para DERVIN e NILAN (1986), a partir dessa preocupação em entender a necessidade de informação mudou-se o paradigma da abordagem tradicional, trazendo uma nova visão aos pesquisadores. Nessa nova visão, o usuário de um sistema de informação passa a ser observado como um cliente e o seu comportamento e os seus processos cognitivos tornam-se o foco dos estudos. Opondo-se a abordagem tradicional, a abordagem alternativa possui uma visão mais holística do usuário, estudando suas necessidades e a maneira como ele interage com o mundo para satisfazê-las. É essa visão holística que se alinha com o conceito de necessidade do Marketing. 
Ainda segundo esses autores, estudos que seguem a abordagem alternativa caracterizam-se por:

- Ver a informação como algo construído pelos seres humanos através de processos cognitivos internos do indivíduo.

- Considerar os usuários seres ativos que estão constantemente construindo significado para as informações que encontram. Seres livres (dentro das limitações dos sistemas) para criar a partir do sistema e das situações que escolherem.

- Buscar compreender como as pessoas constroem sentido e formar uma visão holística de suas experiências. Focam-se no usuário, em entender suas situações particulares de uso de informação e no que ocorre antes e depois das suas interações com o sistema.

- Formular perguntas na pesquisa que nascem dos usuários, da visão que eles têm do sistema de informação e de como e porque eles o utilizam. Perguntas comuns são: "Por que alguém usa?", "O que acha que o sistema oferece de útil?”, "Como os usuários definem suas necessidades em diferentes situações?", “Como eles apresentam suas necessidades ao sistema?", "Como os usuários fazem uso do que o sistema oferece?".

- Utilizar técnicas qualitativas de pesquisa.

A abordagem alternativa tem sido pesquisada por diversos autores em diferentes vertentes. FERREIRA (1997) cita as seguintes, consideradas as mais expressivas:

a) Abordagem de "Valor Agregado" de Robert Taylor - User-Values ou Value-Added

b) Abordagem do "Estado de Conhecimento Anômalo" de Belkin e Oddy - Anomalous State-of-Knowledge 
c) Abordagem do "Processo Construtivista" de Carol Kuhlthau Constructive Process Approach

d) Abordagem “Sense-Making” de Brenda Dervin

Ainda segundo FERREIRA (1997, pág. 15), “enquanto as abordagens de Taylor, Kuhlthau, Belkin e Oddy têm contribuído com argumentos conceituais e teóricos profundos para o paradigma alternativo dos estudos de usuários, DERVIN vai além apresentando um método bastante elucidativo para mapear necessidades de informação sob a ótica do usuário".

O trabalho da Arquitetura de Informação, segundo ROSENFELD e MORVILLE (2002) consiste em compreender e atender a três dimensões de variáveis. A primeira são os usuários, suas necessidades, tarefas, hábitos e comportamentos. A segunda são as características do conteúdo que será apresentado (objetivo, uso, volume, formato, estrutura, governança, dinamismo). Por fim a terceira são as especificidades do contexto de uso do sistema de informação (proposta de valor de website, cultura e política da empresa, restrições tecnológicas, localização, etc.).

Assim, das abordagens oferecidas pela Ciência da Informação, a abordagem alternativa é a que melhor espelha o trabalho da Arquitetura de Informação. A sua visão situacional se alinha com a preocupação da Arquitetura de Informação em entender o contexto de uso da informação. A sua preocupação em compreender holisticamente a experiência do usuário vai ao encontro da necessidade que a Arquitetura de Informação tem de conhecer seus usuários, suas motivações e seus comportamentos. Por fim a sua idéia de que a informação é algo construído pelo usuário se alinha com a preocupação da Arquitetura de Informação em compreender detalhadamente os conteúdos que oferece aos seus usuários e que usos fazem deles.

A abordagem tradicional se opõe a tudo isso. Sua característica trans-situacional não é capaz de oferecer meios para explicar a contextualização, as influências que cada situação de uso traz para a compreensão da informação. A sua visão passiva do usuário não é capaz de explicar a maneira com que ele procura informação na Web e constrói significado ao utilizá-la. A navegação na Web é um ato interativo e construtivo 
representado na escolha "por qual link seguir" feita pelo próprio usuário. E por último, sua visão da informação como algo objetivo, com significado constante não traduz o fato de que diferentes grupos de usuário têm necessidades, compreensões e usos diferentes para a mesma informação.

\subsection{Síntese}

Tanto a abordagem de Design Centrado no Usuário da Interação HumanoComputador quanto da Ciência da Informação buscam conhecer e atender o usuário tendoo no centro das decisões ao realizar o design de seus sistemas. Porém cada uma dessas abordagens possui princípios próprios, mas que se complementam.

A Interação Humano-Computador tem como foco compreender como o usuário executa suas tarefas ao interagir com as interfaces computacionais e por isso apresenta uma visão mais operacional, voltada principalmente ao uso do sistema. Através das suas avaliações de usabilidade, essa disciplina busca mapear as dificuldades dos usuários nas suas tarefas para tornar o uso das interfaces computacionais mais fácil e intuitivo.

A Ciência da Informação, de forma complementar, busca compreender toda a situação e o comportamento do usuário na sua busca de informação, antes, durante e depois da sua interação com o sistema. Por isso essa ciência apresenta uma visão mais holística do usuário, de suas necessidades e de como ele se relaciona com o mundo, fruto de um pensamento mais reflexivo.

Essas duas disciplinas podem trazer importantes contribuições para a Arquitetura de Informação, fornecendo técnicas e fundamentação teórica para a sua metodologia de projetos. A abordagem da Interação Humano-Computador pode contribuir com técnicas para identificar as tarefas dos usuários e avaliar seu uso do website. Já a abordagem de Design Centrado no Usuário da Ciência da Informação pode contribuir com técnicas para realizar pesquisas mais abrangente sobre os usuários e suas necessidades. 


\section{Arquitetura de Informação de websites}

Nascida em 1969, graças a programas de pesquisa científica e militar nos Estados Unidos, a Internet é uma grande rede com milhões de computadores conectados que se impregnou na vida da nossa sociedade contemporânea. Entre todos os serviços oferecidos por essa rede, o mais popular é o Word Wide Web (apelidado de WWW ou Web), que permite o acesso fácil a um sistema de páginas de hipertexto multimídia hospedadas em milhões de computadores espalhados por todo o mundo. Cada uma destas páginas de hipertexto é denominada de webpage (ou página web) e o lugar virtual na rede onde estão hospedadas é denominado website (ou simplesmente site). Cada website e cada webpage são identificados por meio de um endereço eletrônico virtual denominado URL (Uniform Resource Location) e são acessados por meio de softwares específicos, os browsers. Distribuídos gratuitamente, os browsers são fáceis de usar e popularizaram o uso da Internet porque permitem que um usuário comum consiga navegar pelas webpages por meio de uma interface gráfica simples, baseada em janelas e com o uso de um mouse.

O crescimento da Web a transformou em um gigantesco ambiente informacional. Segundo a NETCRAFT (2007) atualmente existem mais de 108 milhões de websites e 
surgem mais de um milhão de novos websites todos os meses. Porém sua grande flexibilidade e seu crescimento desordenado tornaram a Web um sistema extremamente desorganizado e heterogêneo se comparado a outros sistemas de informação. Sua diversidade de conteúdos, formatos e audiência complicam muito a tarefa de indexar e procurar informação nela.

A rede é como uma imensa biblioteca vandalizada. Alguém destruiu o catálogo e removeu capas, índices, etc. de centenas e milhares de livros, rasgou-os e espalhou o que sobrou... "Surfar" 4 é o processo de peneirar essa massa desorganizada na esperança de cruzar com fragmentos úteis de texto e imagem que podem ser relacionados a outros fragmentos. A rede é ainda pior que uma biblioteca vandalizada porque milhares de fragmentos desorganizados são adicionados diariamente pelos milhões de excêntricos, sábios e pessoas com tempo em suas mãos e que lançam suas mensagens sem filtro no ciberespaço.

(GORMAN apud MORROGH, 2003, pág. 99)

Em meados do anos 90, com os grandes investimentos das empresas para desenvolver seus websites e novos negócio na Web, a forma de desenvolvimento de websites evoluiu para metodologias formais e multi-disciplinares. Foi nesse momento que surgiram as primeiras tentativas de aplicar conceitos de Arquitetura de Informação no design de websites com o objetivo de melhorar a organização das suas informações. Em 1994, Louis Rosenfeld e Peter Morville, ambos com formação em Ciência da Informação e Biblioteconomia, fundaram a Argus Associates, a primeira empresa dedicada exclusivamente a trabalhar com Arquitetura de Informação na Web. A ação pioneira da Argus logo foi seguida por outras empresas especializadas em projetos de websites como a Sapient, Scient, Viant, Agency.com, IXL, marchFIRST, Rare Medium, Zefer, Luminant e Razorfish. Todas elas adotaram formalmente a Arquitetura de Informação como uma disciplina necessária para a execução de seus projetos.

\footnotetext{
${ }^{4}$ Surfar é uma gíria utilizada entre os usuários de Internet que significa navegar, percorrer as páginas de hipertexto na web.
} 
O termo Arquitetura de Informação, porém, surgiu bem antes da popularização da Internet. Ele foi criado por WURMAN, em 1976, para denominar seu trabalho de tornar a informação mais compreensível. Sua motivação foi a oferta explosiva de informação, característica do nosso mundo moderno, que provoca nos usuários uma sensação de distanciamento entre o que se compreende e o que se deveria compreender.

Essa sensação de distanciamento desperta nos usuários um sentimento de angústia, de ansiedade provocado pela excessiva oferta de informação. O psicólogo britânico Davis Lewis batizou os efeitos físicos, psicológicos e sociais da sobrecarga da informação sobre um indivíduo de síndrome da fadiga da informação. Alguns dos seus efeitos são estresse, tensão, distúrbios de sono, problemas digestivos, dificuldade de memorização, irritabilidade e sentimento de abandono (ANTUNES, 1998).

A sobrecarga de informações, por causar distração e atraso em decisões, também afetaria organizações (...), tornando-as menos eficientes e lucrativas. Isso pode representar um grave problema, principalmente considerando-se que tal situação pode tornar os funcionários ainda menos aptos a receber informação, agravandoa cada vez mais, de maneira cíclica. (SATO e HASHIMOTO, 2004, pág. 12)

A Arquitetura de Informação surgiu para combater esse sentimento de ansiedade com propósito de "organizar os padrões inerentes dos dados e criar a estrutura ou mapa da informação de forma a permitir que outros encontrem seus próprios caminhos para o conhecimento tornando o complexo claro" (WURMAN, 1997, pág. 16). Seus conceitos foram inicialmente aplicados na organização de materiais gráficos, como guias, mapas e Atlas, mas se espalharam por diversos outros campos, que vão desde a organização do layout de museus até a estruturação de imagens radiográficas para uso médico (WURMAN, 1997).

Em 1998, ROSENFELD e MORVILLE publicaram a primeira edição do livro Information Architecture for the World Wide Web. A segunda edição foi publicada em 2002 e a terceira em novembro de 2006. Apelidado, nas listas de discussão da área, de livro do "urso polar" (a capa tem o desenho desse animal), esse livro marca o início da Arquitetura de Informação na Web e rapidamente se tornou a principal referência sobre o assunto. 
A primeira conferência internacional sobre Arquitetura de Informação da American Society for Information Science (ASIS) ocorreu em abril de 2000 com o nome Defining Information Architecture (Definindo a Arquitetura de Informação). Desde então a ASIS realiza anualmente o IA Summit, a mais importante conferência internacional sobre o tema.

Em 2002 surgiu a primeira comunidade formal de profissionais de Arquitetura de Informação, o Asilomar Institute for Information Architecture (AIfIA) que, em 2005, mudou seu nome para Information Architecture Institute. Contando com mais de 1000 membros em 60 países, esse instituto "é uma organização sem fins lucrativos composta por voluntários e dedica-se ao avanço e promoção da Arquitetura da Informação." (INFORMATION ARCHITECTURE INSTITUTE, 2005).

A Argus Associates encerrou suas atividades em março de 2001, junto com várias das empresas citadas devido a estratégias de negócios imaturas que não conseguiram atravessar a explosão da bolha da Internet. Mas os conceitos da Arquitetura de Informação continuam a ser fundamentais no design de websites.

A Arquitetura de Informação recentemente emergiu como uma importante metadisciplina preocupada com o design, a implementação e a manutenção de espaços digitais de informação para seres humanos acessarem, navegarem e usarem... $O$ termo tem sido utilizado por vários anos para descrever o mix de competências requeridas para produzir recursos de informação que aumentam as habilidades humanas de localizar informação.

(JOURNAL OF AMERICAN SOCIETY FOR INFORMATION SCIENCE \& TECHNOLOGY apud MORROGH, 2003, pág. 107)

\subsection{0 que é Arquitetura de Informação de websites?}

Diante da complexidade do hipertexto torna-se necessário planejar e estruturar as informações visando acessibilidade pelos usuários. Assim como no labirinto o Fio de Ariadne marca o caminho para a volta de Teseu após matar o Minotauro, a Arquitetura da Informação procura mapear o labirinto imprimindo certo grau de 
ordem ao hipertexto. É um campo de trabalho bastante definido e seu alcance não vai além do site, não se propondo a "organizar" a rede como um todo. É tanto uma referência para o objetivo que se pretende atingir como para a saída. Permite uma caminhada - ou navegação - que pode ser feita, mas também abre a possibilidade de trilhar múltiplos caminhos que levem a um mesmo objetivo. (LARA FILHO, 2003)

Apesar da sua evolução, a Arquitetura de Informação ainda segue a definição criada originalmente por WURMAN: trata de organizar a informação para torná-la clara. $\mathrm{Na}$ Web, esse objetivo se mantém: criar as estruturas de organização da informação apresentada por um website para que o usuário consiga encontrar e compreender as informações que necessita e desempenhar suas tarefas com facilidade.

No projeto de websites, a Arquitetura de Informação é responsável por definir a estrutura, o esqueleto que organiza as informações sobre o qual todas as demais partes irão se apoiar. WEST (2001) cita que "Arquitetura de Informação é a prática de projetar a infra-estrutura de um website, especialmente a sua navegação". SHIPLE (2001) afirma que "Arquitetura de Informação é a fundação para um ótimo webdesign. Ela é o esquema [blueprint] do website em cima do qual todos os outros aspectos são construídos - forma, função, metáfora, navegação, interface, interação e design visual". Por fim BELTON (2003, pág. 143) cita que a “Arquitetura de Informação está atualmente emergindo como uma disciplina que se preocupa com o desenvolvimento de abordagens sistemáticas para a organização e apresentação de informação on-line".

A Arquitetura de Informação não se preocupa apenas com a organização da informação, mas também com a sua apresentação. Ela cria no website um ambiente de informação por onde o usuário pode se mover (navegar) para, como em uma biblioteca, encontrar as informações que precisa de forma organizada.

A idéia da criação de um ambiente pelo qual o usuário se move faz com que autores como BELTON (2003), CHIOU (2003) e MORROGH (2003) comparem a Arquitetura de Informação com a Arquitetura, usando esta última como metáfora para explicá-la. Em ambas o objetivo é balancear forma e função para criar um novo espaço, um novo ambiente que seja útil, agradável e que atenda às necessidades dos seus usuários. 
Atender às necessidades de informação dos usuários é o grande objetivo da Arquitetura de Informação e é o que justifica a sua preocupação em seguir abordagens de Design Centrado no Usuário. DIJCK (2003, pág. 3) mostra isso ao citar que "o trabalho principal do arquiteto de informação é organizar a informação em um website para que os usuários consigam encontrar as coisas e alcançar seus objetivos". TOUB (2000, pág. 2) corrobora ao afirmar que "Arquitetura de Informação é a arte e a ciência de estruturar e organizar ambientes de informação para ajudar as pessoas a satisfazerem suas necessidades de informação de forma efetiva".

Na definição de TOUB se observa a dicotomia entre "ciência" e "arte" da Arquitetura de Informação. No seu lado "ciência", a Arquitetura de Informação busca criar um corpo teórico para embasar as suas técnicas. Porém a quantidade de variáveis envolvidas nos projetos é tão grande que, na prática, é impossível não ter decisões subjetivas, fazendo dela também uma "arte" (MORVILLE, 2005).

O objetivo de realizar o design de estruturas informacionais com o propósito de facilitar a busca de informação pelo usuário e a dicotomia entre "ciência" e "arte" também é visto na definição do INFORMATION ARCHITECTURE INSTITUTE (2005) sobre o que é Arquitetura de Informação:

1. O design estrutural de ambientes de informação compartilhados.

2. A ciência e a arte de organizar e rotular websites, intranets, comunidades on-line e softwares para dar suporte à usabilidade e facilidade de encontrar informação.

3. Uma comunidade de práticas emergentes, focada em trazer princípios do design e arquitetura para o ambiente digital.

Por fim o livro do urso polar (ROSENFELD e MORVILLE, 2002) une todos esses conceitos e define Arquitetura de Informação como:

1. A combinação dos esquemas de organização, rotulação e navegação dentro de um sistema de informação.

2. O design estrutural do espaço informacional para facilitar a completude das tarefas e o acesso intuitivo ao conteúdo. 
3. A arte e a ciência de estruturar e classificar websites e intranets para ajudar as pessoas a encontrar e gerenciar informação.

4. Uma disciplina emergente e uma comunidade de prática focada em trazer princípios do design e arquitetura ao espaço digital.

Segundo ROSENFELD e MORVILLE (2002), a Arquitetura de Informação busca compreender e atender a três dimensões de variáveis para organizar a informação. A primeira dimensão são os usuários, suas necessidades, hábitos e comportamentos. A segunda dimensão são as características do conteúdo que será apresentado (volume, formato, estrutura, governança, dinamismo, etc.). Por fim a terceira dimensão são as especificidades do contexto de uso do sistema de informação (objetivo do website, cultura e política da empresa, restrições tecnológicas, localização, etc.).

Esse trio, usuário-conteúdo-contexto, e suas interdependências são únicos para cada website. O papel do arquiteto é conseguir balanceá-lo para que a informação certa seja acessada pela pessoa certa no momento certo. É uma aplicação moderna das leis da biblioteconomia de Ranganathan (apud GOMES e colab., 2006): "Livros são para Uso", "Para cada Leitor, seu Livro", "Para cada Livro, seu Leitor", "Poupe o tempo do Leitor" e "A Biblioteca é uma organização em crescimento".

Um projeto de arquitetura de informação produz, como produto final, documentos que especificam toda a organização informacional do website (DIJCK, 2003) com duas características básicas:

- Registrar as regras de classificação, ordenação, navegação, rotulação e busca do website;

- Demonstrar a aplicação dessas regras nos conteúdos e serviços do website, gerando mapas de navegação (sitegramas e fluxos de navegação), esquemas das páginas (wireframes) e o vocabulário controlado.

A documentação das regras registra o modelo mental do projetista e é utilizada para manter a consistência nas manutenções futuras. A documentação da aplicação das regras demonstra sua viabilidade para os conteúdos e transações do website no contexto 
do projeto e formam a especificação técnica necessária para os responsáveis pela sua implementação (webdesigners, redatores, programadores, etc.).

Por ser um campo novo, as definições apresentadas sobre a Arquitetura de Informação e seus produtos ainda não são permanentes e expressam apenas parte das atribuições de um arquiteto de Informação (INFORMATION ARCHITECTURE INSTITUTE, 2005). Segundo REISS (2000) o primeiro IA SUMMIT foi uma boa demonstração da dificuldade de definir esse campo. Esse evento teve por objetivo construir essa definição, porém não conseguiu que seus 400 participantes chegassem a um consenso sobre o que é Arquitetura de Informação e o que exatamente um arquiteto de informação faz.

\subsubsection{Um exemplo}

O exemplo a seguir, extraído do livro Ansiedade de Informação do WURMAN (1991, pág. 286) ilustra o trabalho de um arquiteto de informação. Trata-se de um mapa elaborado para a mídia impressa, mas que apresenta de forma simples os conceitos da Arquitetura de Informação.

$\mathrm{Na}$ figura a seguir estão duas versões do mapa da linha férrea de Yamanote, que circunda a cidade de Tóquio. O mapa da esquerda está em escala real e mostra todas as curvas que o trem faz ao longo do seu trajeto. O mapa a direita é o resultado do trabalho de um arquiteto de informação que o redesenhou para os usuários dessa linha. Apesar de mais abstrato, o segundo mapa é mais eficiente que o primeiro para quem utiliza a linha Yamanote. Passageiros de trem estão num contexto onde não lhes importa quais são as curvas que o trem faz entre as estações simplesmente porque eles não têm nenhum controle sobre o movimento do trem, não conseguem pará-lo, direcioná-lo nem subir ou descer entre as estações. Para eles a informação que interessa é a seqüência e a identificação das paradas.

O mapa da direita apresenta exatamente e somente isso. Sua forma circular também enfatiza que o trem circunda toda a cidade. E como o Palácio Imperial é um importante ponto de referência em Tóquio, ele esta destacado. $\mathrm{O}$ desenho do mapa 
também se assemelha com o símbolo do Yin Yang, que traz uma forte identificação cultural para os povos orientais.

Figura 2 - Mapas da linha de trem Yamanote em Tóquio (WURMAN, 1991)
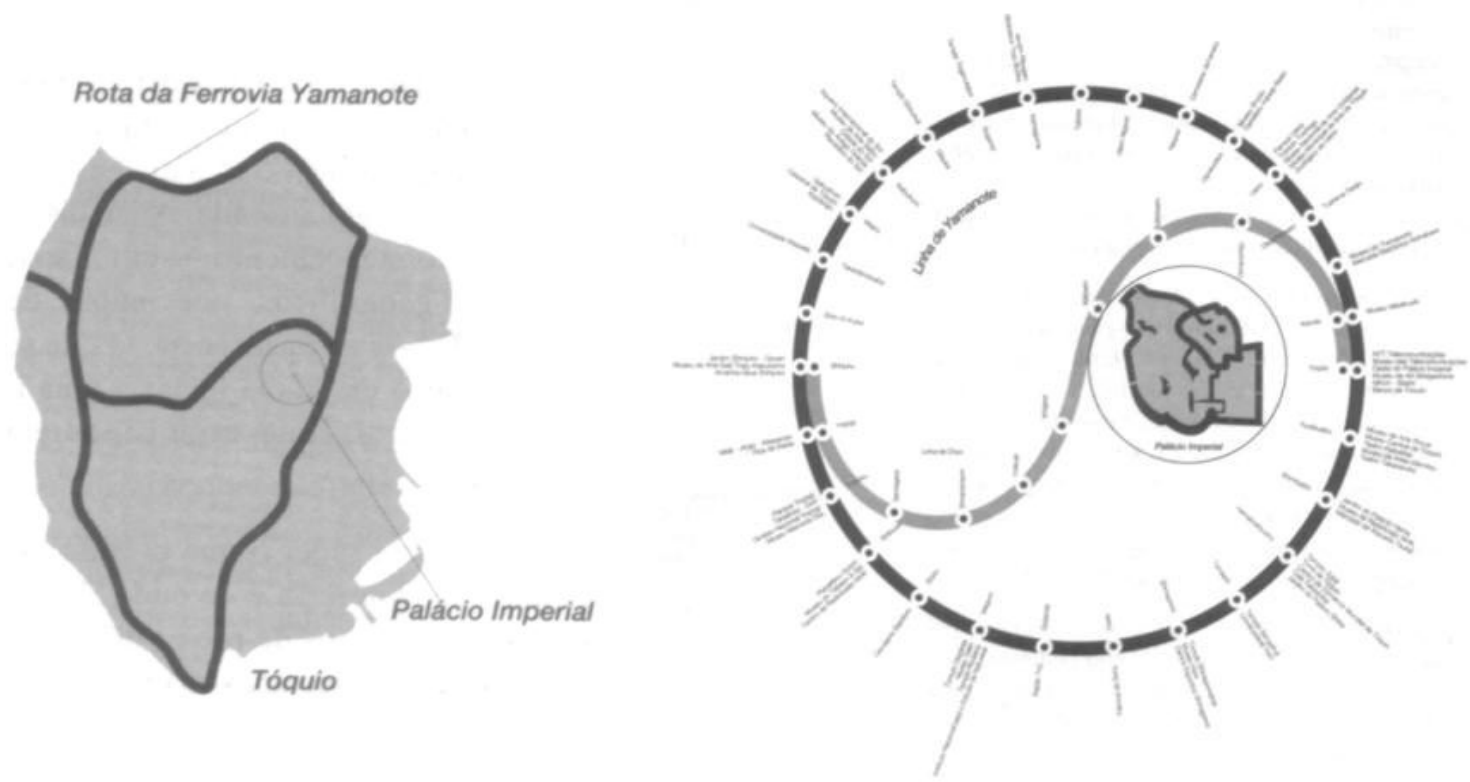

\subsubsection{Por que a Arquitetura de Informação é importante?}

Para que todo o investimento feito na produção de um website tenha retorno é necessário que o mesmo seja fácil de aprender e usar.

Com cerca de 10 milhões de websites na Web em janeiro de 2000 (...), os usuários nunca tiveram tantas opções. Por que devem desperdiçar seu tempo em websites confusos, lentos ou que não satisfaçam às suas necessidades? Realmente, por quê? Como resultado dessa quantidade esmagadora de opções e facilidade de ir para outros websites, os usuários da Web demonstram uma notável impaciência e insistência na gratificação instantânea. Se não conseguirem descobrir como usar um website em aproximadamente um minuto, concluem que não vale a pena gastar seu tempo. E saem. (NIELSEN, 2000, pág. 10)

A organização das informações é um dos principais problemas que afeta o uso dos websites. Pesquisas do NIELSEN NORMAN GROUP (2001) apontam que 27\% das 
causas de insucesso das vendas de um website de comércio eletrônico ocorrem porque o usuário simplesmente não conseguiu encontrar o item que procurava.

Falhas na organização dificultam a utilização de um website porque, ao não encontrar a informação que deseja, o usuário fica confuso, frustrado e irritado, o que faz com que ele não alcance seus objetivos, repercutindo diretamente no retorno do investimento (ROSENFELD e MORVILLE, 2002).

Categorização tem conseqüências. Uma seção com um rótulo confuso num website de referências médicas pode impedir o médico de encontrar uma nova pesquisa que salvará a vida de alguém. Um website de uma universidade mal organizado desencoraja um estudante pobre que pode pensar que não existem ajudas financeiras para estudar lá, e uma loja virtual confusa resulta em perda de vendas. (WODTKE, 2003, pág. 118)

MORVILLE (2004) cita que a Arquitetura de Informação afeta diretamente os custos de encontrar uma informação e de não encontrá-la, os custos de construção e manutenção dos websites, os custos de treinamentos de funcionários e até a valorização da marca.

Estudo do IDC (FELDMAN e SHERMAN, 2001) aponta que, internamente nas empresas, os custos relativos à busca de informação inexistente, a falhas em encontrar informação existente ou para recriar informação não encontrada é da ordem de 15 milhões de dólares.

Enquanto os custos de não encontrar informação são enormes, eles estão escondidos dentro da empresa, e por isso eles são raramente percebidos como tendo impacto nos resultados finais. Decisões são geralmente problemas informacionais. Se elas são tomadas com informação pobre ou errônea, elas colocam a vida da empresa numa aposta. (FELDMAN e SHERMAN, 2001, pág. 9)

Por fim, a Tabela 4, que resume uma pesquisa da VIVIDENCE RESEARCH (2001) realizada com 69 websites sobre seus problemas mais comuns, mostra a importância da Arquitetura de Informação. Nota-se que a Arquitetura de Informação é 
responsável por cinco dos sete grandes problemas mais comuns nos websites: resultados de busca mal organizados, arquitetura de informação pobre, home-page desorganizada, rótulos confusos e navegação inconsistente.

Tabela 4 - Problemas mais comuns nos websites (VIVIDENCE RESEARCH, 2001)

\begin{tabular}{|c|c|c|}
\hline Problema & Percentual de websites & Como este problema afeta o usuário \\
\hline $\begin{array}{l}{ }^{*} \text { Resultados de busca } \\
\text { mal organizados }\end{array}$ & $53 \%$ & $\begin{array}{l}\text { - Frustração } \\
\text { - Perda de tempo }\end{array}$ \\
\hline $\begin{array}{l}\text { *Arquitetura de } \\
\text { informação pobre }\end{array}$ & $32 \%$ & $\begin{array}{l}\text { - Confusão } \\
\text { - Caminhos sem saída } \\
\text { - Uso excessivo dos botões voltar e avançar do browser } \\
\text { - Força o usuário a usar o mecanismo de busca }\end{array}$ \\
\hline Desempenho lento & $32 \%$ & $\begin{array}{l}\text { - Interrupção constante na experiência de compra } \\
\text { - Frustração }\end{array}$ \\
\hline $\begin{array}{l}{ }^{*} \text { Home-Page } \\
\text { desorganizada }\end{array}$ & $27 \%$ & $\begin{array}{l}\text { - Cria desinteresse } \\
\text { - Perda de tempo }\end{array}$ \\
\hline * Rótulos confusos & $25 \%$ & $\begin{array}{l}\text { - Confusão } \\
\text { - Erros } \\
\text { - Uso excessivo dos botões voltar e avançar do browser } \\
\text { - Força o usuário a usar o mecanismo de busca }\end{array}$ \\
\hline $\begin{array}{l}\text { Processo de registro } \\
\text { invasivo }\end{array}$ & $15 \%$ & $\begin{array}{l}\text { - Usuários são apenas números } \\
\text { - Visitante se sente ressentido } \\
\text { - Perda de tempo e esforço para entrar com os dados }\end{array}$ \\
\hline $\begin{array}{l}\text { *Navegação } \\
\text { inconsistente }\end{array}$ & $13 \%$ & $\begin{array}{l}\text { - Caminhos ineficientes } \\
\text { - Força o usuário a se focar na navegação, não no uso. } \\
\text { - Perda da estabilidade percebida } \\
\text { - Funcionalidades úteis não são encontradas }\end{array}$ \\
\hline
\end{tabular}

* Os problemas destacados são relacionados com a Arquitetura de Informação.

\subsubsection{A multi-disciplinariedade da Arquitetura de Informação}

Segundo LATHAM (2002), definir um corpo teórico é um aspecto fundamental para qualquer profissão se legitimar. Para esse autor, a falta de um corpo teórico faz com que o profissional comece cada novo problema sem uma referência, o que coloca seu trabalho mais próximo de um artesão do que de um especialista.

No seu atual estágio de evolução, a Arquitetura de Informação ainda é um campo novo, que busca se definir e formar seu corpo teórico. Para tanto está utilizando uma abordagem multi-disciplinar, como mostra o diagrama das disciplinas relacionadas com o design de sistemas de informação na Web proposto por ROSENFELD (2001) e apresentado na Figura 3. Disciplinas com corpos teóricos já estabelecidos fornecem ferramentas, técnicas, experiência e credibilidade para as novas disciplinas como a Arquitetura de Informação. Essas novas disciplinas unificam os métodos e técnicas em uma nova forma de pensar. 
Figura 3 - Disciplinas que colaboram na formação do corpo teórico da Arquitetura de Informação (ROSENFELD, 2001)

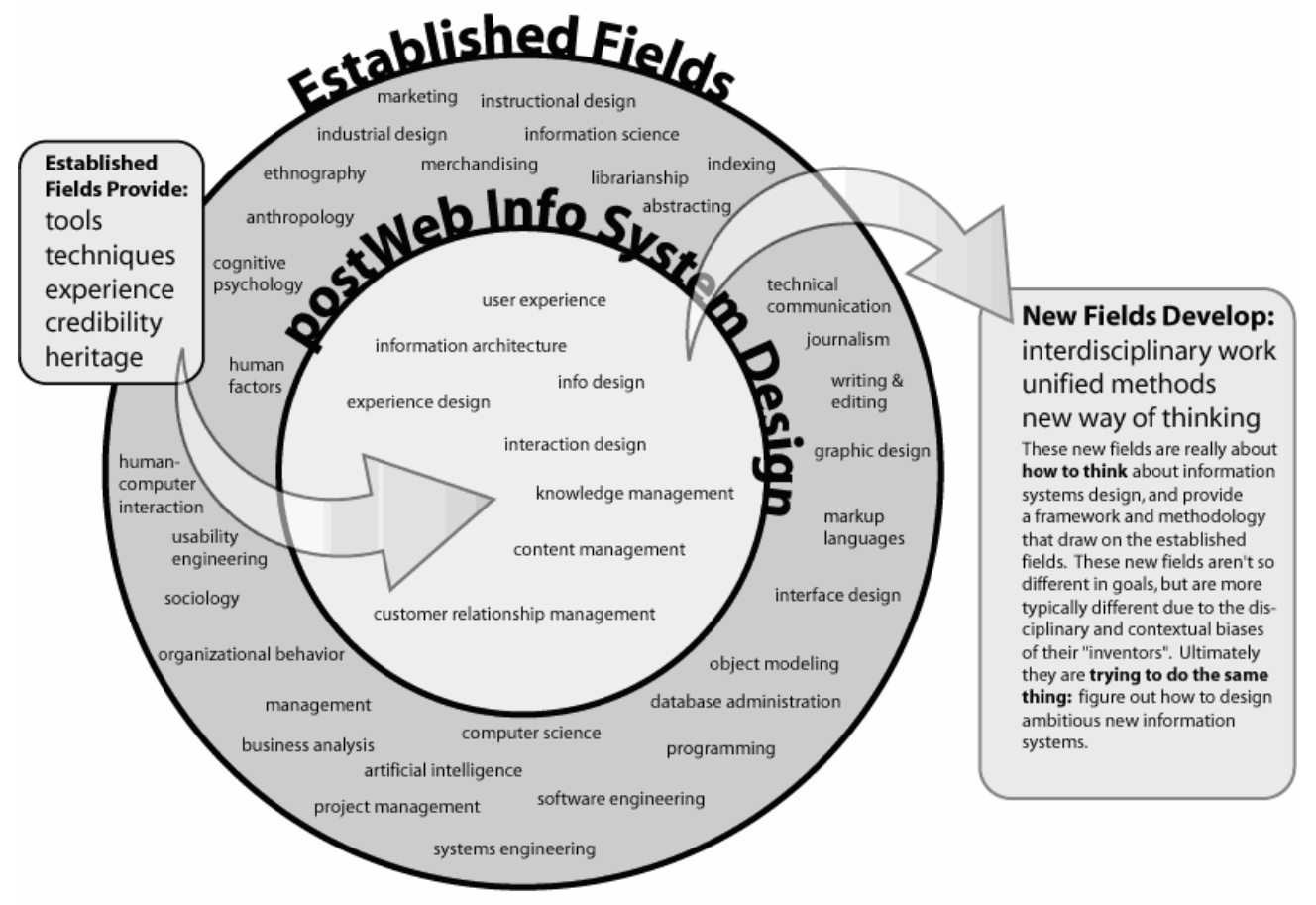

LATHAM (2002) aponta esse caráter multi-disciplinar ao sugerir cinco áreas chave para a formação do arquiteto de informação: organização da informação, design gráfico, ciência da computação, usabilidade e comunicação.

A GSIS-UTA, Graduate School of Library and Information Science at the University of Texas at Austin, ao avaliar o currículo de seu curso de Arquitetura de Informação, examinou o currículo de seis respeitadas universidades que oferecem cursos de especialização nessa área e encontrou, apesar das diferenças de nomenclatura, sete áreas fundamentais para a formação do arquiteto de informação (MORROGH, 2003). São elas:

- Sistema de Informação / Gerenciamento / Organização

- Busca e recuperação da informação

- Gerenciamento de banco de dados

- Metodologia de pesquisa / Estatística

- Interação Humano - Computador

- Rede de Computadores

- Gerenciamento de Projetos 
O motivo da multi-disciplinariedade da Arquitetura da Informação vem da riqueza de aplicações que esse novo campo está encontrando na sua evolução (WURMAN, 1997) e dos diferentes públicos com que o arquiteto de informação se relaciona durante um projeto (DIJCK, 2003).

$O$ arquiteto de informação deve agir como um mediador entre cliente, usuário, áreas de negócio, designers gráficos e programadores. Ele irá dirigir uma grande variedade de atividades desde a análise de conteúdo até pesquisas de focus group e modelagem de webpages. $O$ arquiteto de informação efetivo tem um arsenal de habilidades técnicas misturadas com uma eficiente comunicação interpessoal, que coloca ele no centro de uma complexa teia de comunicação entre diferentes visões e idéias. $O$ arquiteto de informação desempenha o papel de um diplomata mantendo a coesão entre os membros do time e assegurando que o projeto permaneça no prazo e alcança seus objetivos.

(EWING e colab., 2002)

\subsection{Os componentes da arquitetura de informação para a Web}

ROSENFELD e MORVILLE (2002) dividem a arquitetura de informação de um website em quatro grandes sistemas interdependentes, cada um composto por regras próprias e aplicações. Juntos eles reúnem todos os elementos de interação do usuário com o ambiente informacional do website e servem de modelo para organizar o trabalho do arquiteto. São eles:

- Sistema de Organização (Organization System): Define o agrupamento e a categorização de todo o conteúdo informacional.

- Sistema de Navegação (Navegation System): Especifica as maneiras de navegar, de se mover pelo espaço informacional e hipertextual.

- Sistema de Rotulação (Labeling System): Estabelece as formas de representação, de apresentação, da informação definindo signos para cada elemento informativo.

- Sistema de Busca (Search System): Determina as perguntas que o usuário pode fazer e o conjunto de respostas que irá obter. 
Vale notar que a divisão da arquitetura de informação nesses quatro sistemas é apenas conceitual e destina-se a organizar o trabalho do arquiteto de informação. Todos esses sistemas apresentam uma grande interdependência de modo que os problemas de um deles normalmente afetam os demais. Apesar disso, analisá-los separadamente facilita a busca das dificuldades de projetá-los porque cada um deles é conceituado com bases teóricas advindas de disciplinas diferentes.

Outros autores como WODTKE (2003), DIJCK (2003), SHIPLE (2001) e BRINCK e colab. (2002) confirmam que o design dos três primeiros sistemas é responsabilidade do arquiteto de informação, porém não citam o sistema de busca.

Juntos, os sistemas de organização, de navegação e de rotulação fornecem os elementos necessários para o usuário executar a navegação pelas categorias e reúnem os principais elementos de interação do usuário. Esses três sistemas formam a imagem do sistema, que cria o modelo mental do funcionamento do website. Alterar esses sistemas envolve a reorganização, reclassificação e readequação de todo o conteúdo, além de que obriga o usuário a reaprender a utilizar o website.

O sistema de busca, ao contrário, pode ser visto como uma peça modular, que se encaixa a qualquer momento no website. Essa modularidade é tão evidente que diversos websites de busca, como o Google e Yahoo!, possuem serviços e tutoriais mostrando como utilizá-los para criar o sistema de busca em qualquer website. Além disso, efetuar ajustes no sistema de busca pós-projeto é relativamente simples e barato quando comparado com os outros três sistemas, sendo inclusive uma prática recomendada para melhorar a sua usabilidade (ROSENFELD e MORVILLE, 2002).

Desta forma, esse trabalho está focado apenas nos sistemas de organização, de navegação e de rotulação porque esses são os sistemas mais importantes para se projetar a estrutura de organização da informação de um website. O design do sistema de busca não será considerado ${ }^{5}$.

\footnotetext{
${ }^{5}$ Para mais informações sobre o design do sistema de busca veja ROSENFELD e MORVILLE, 2002, cap 8.
} 
A seguir estão apresentados os principais fundamentos teóricos e as dificuldades do projeto desses três sistemas.

\subsubsection{Sistema de Organização}

Os sistemas de informação possuem uma característica em comum e que justifica todo o trabalho de Arquitetura de Informação: localizar informação em um espaço organizado é mais fácil que em um espaço desorganizado. WODTKE (2003, pág. 89) cita que "é um fato simples que quando você tem certa quantidade de coisas, você tem que organizá-las. Do contrário, você não consegue achar nada.” LIMA (2003, pág. 83) afirma que "a informação estruturada é mais fácil de ser recuperada do que a informação desorganizada".

Um website, como qualquer outro sistema de informação, precisa que as suas informações estejam organizadas para que o usuário consiga encontrar facilmente o que deseja. Websites desorganizados são verdadeiros jogos de caça-palavras que obrigam o usuário a encontrar a informação que deseja no meio da bagunça causando-lhe frustração e irritação. Ao acessar um website, o usuário quer resolver seus problemas, alcançar seus objetivos e concluir suas tarefas. Não quer ser desafiado por um jogo de passatempo.

O sistema de organização é o componente da arquitetura de informação que tem por função definir as regras de classificação e ordenação das informações que serão apresentadas e aplicá-las categorizando ${ }^{6}$ todos os conteúdos oferecidos (ROSENFELD e MORVILLE, 2002). Seu principal desafio é organizar a informação de forma a torná-la facilmente compreensível e que ajude o usuário a encontrar o que precisa para atingir seu objetivo.

Porém categorizar informação envolve vários aspectos cognitivos e sócio-culturais que tornam esse trabalho bastante subjetivo.

\footnotetext{
${ }^{6}$ Segundo Lima (2003, pág 82) "muitos autores consideram os termos categorização e classificação como sinônimos (Gardner, 1996; Jacob \& Shaw, 1991; Smith \& Medin, 1981)." Nesse trabalho esses termos também são considerados sinônimos.
} 


\subsubsection{O que é categorizar?}

Categorizar é agrupar entidades (objetos, idéias, ações, etc.) por semelhança. Essa é uma habilidade natural que a mente humana usa para compreender o mundo ao seu redor. JACOB e SHAW (1998, pág. 155) definem que "categorizar é o processo cognitivo de dividir as experiências do mundo em grupos de entidades, ou categorias, para construir uma ordem dos mundos físico e social em que o indivíduo participa.” MARKMAN (apud JACOB e SHAW, 1998, pág. 155) complementa dizendo que "categorização é um mecanismo cognitivo fundamental que simplifica a interação do indivíduo com o ambiente: ela não apenas facilita o armazenamento da informação, mas também reduz a demanda da memória humana".

A preocupação da humanidade com a categorização remonta aos tempos de Aristóteles e suas teorias sobre a classificação dos seres (LIMA, 2003). Na visão aristotélica, uma categoria é um conjunto abstrato onde todos os elementos dentro desse conjunto possuem propriedades em comum e os elementos fora dele não possuem tais propriedades. "As categorias de Aristóteles, isso deve ser notado, estavam arranjadas em uma maneira hierárquica, na crença de que existia uma hierarquia perfeita para o mundo tudo o que teríamos de fazer seria encontrá-la" (TAYLOR, 1999, pág. 174). Um dos melhores exemplos contemporâneos de aplicação dessa teoria é o sistema de classificação dos seres vivos utilizado na Biologia que os divide nas categorias hierárquicas Reino, Filo, Classe, Ordem, Família, Gênero e Espécie.

Segundo TAYLOR (1999), essa teoria de Aristóteles, também chamada de teoria clássica da categorização, permaneceu inalterada até meados do século XX quando estudos de diversos autores a contestaram. LAKOFF (1990, pág. 6) cita que "essa teoria clássica não era resultado de estudos empíricos. Ela nem era um assunto de maior debate. (...) De fato, até muito recentemente, a teoria clássica das categorias não era nem considerada como uma teoria. Ela era considerada em muitas disciplinas não como hipóteses empíricas, mas como uma inquestionável e definitiva verdade". 
Segundo LAKOFF (1990) a teoria clássica possui duas implicações básicas:

1. As categorias são definidas apenas pelas propriedades comuns a todos seus membros. Assim nenhum membro pode ser considerado um melhor exemplo da categoria que os demais.

2. As categorias são definidas apenas pelas propriedades inerentes de seus membros. Dessa forma, elas devem ser independentes de quem estiver categorizando, ou seja, elas não devem ser influenciadas pelos movimentos do corpo humano, pela neurofisiologia humana e pelas capacidades humanas de percepção, aprendizado, lembrança e comunicação. Fatores sócio-culturais também não devem influenciar a formação das categorias.

A partir da década de 50 diversos estudos começaram a contestar a teoria clássica estabelecendo uma quebra de paradigma. Sintetizando LAKOFF (1990) e TAYLOR (1999) temos um breve histórico desses estudos:

Wittgenstein, em 1953, propõe a idéia de semelhanças familiares (family resemblances), na qual uma categoria pode ser formada não por um conjunto de propriedades em comum, mas porque seus membros se assemelham. Esse autor cita como exemplo a categoria "jogo" e afirma que nessa categoria não existe nenhum conjunto de propriedades comum e exclusivas a todos os seus membros.

Austin, em 1961, estende os conceitos de Wittgenstein ao analisar o significado das palavras. Esse autor descobre que nomeamos entidades diferentes pelo mesmo nome porque elas possuem similaridade, ou seja, são parcialmente idênticas, indo contra a teoria clássica (Ex: pé da montanha, pé da mesa, pé da pessoa. Apesar de todos terem "pé" não estão na mesma categoria). Em outros casos as entidades estão na mesma categoria, mas não possuem propriedades em comum. (Ex: bola, chuteira e juiz estão todos na categoria futebol).

Zadeh, em 1965, cria a fussy set theory (teoria dos conjuntos confusos), na qual aponta que em algumas categorias existe uma graduação na associação dos elementos. A categoria "senador", por exemplo, é muito bem definida (uma pessoa é senador ou não). 
Mas categorias como "ricos" e "altos" possuem graduação porque existem pessoas mais ricas e mais altas que outras. Nas categorias com graduação cada elemento tem uma probabilidade de pertencer à categoria.

Lounsbury, em 1964, ao estudar o sistema de parentesco dos índios americanos constatou a influência da cultura e da língua na formação das categorias. Contrariando a teoria clássica, esse pesquisador constatou que o que parece definido e distinto em uma cultura e língua não é percebido da mesma forma em outra cultura e língua.

Berlin e Kay, em 1969, em estudos sobre cores constataram que algumas línguas utilizam menos termos para expressar as cores que os onze termos básicos do inglês e também do português (preto, branco, vermelho, amarelo, azul, verde, marrom, roxo, rosa, laranja e cinza). Nas línguas que utilizam menos termos, apesar de seus falantes conseguirem diferenciar todas as onze as cores, não as expressam com nomes diferentes. Algumas línguas, por exemplo, possuem apenas quatro termos básicos para as cores, onde os três primeiros são equivalentes ao preto, branco e vermelho e o último é uma união do amarelo, do azul e do verde.

Kay e McDaniel, em 1978, estenderam os estudos de Berlin e Kay e descobriram que os termos usados para as cores em cada língua não são obras do acaso e sim influenciados pela fisiologia humana. Esses autores aplicaram a fussy set theory em estudos neurofisiológicos sobre a visão e encontraram as causas para diferentes culturas nomearem as cores de formas diferentes.

Brown, em 1965, iniciou os estudos sobre categorias de nível básico (basic-level categories). Ele observou que, apesar de todos os possíveis nomes para alguma entidade existentes em uma hierarquia de categorias, há um nome em particular, em um nível em particular, com um "status superior". Por exemplo, um "cachorro" não é apenas um “cachorro". Ele pode ser também um "quadrúpede", um "mamífero", um "animal” se olharmos para categorias superiores; ou um "cão de caça", um "labrador" se olharmos para categorias inferiores. Mas a categoria "cachorro" se parece mais com seu nome natural. Esse "nome natural" é o que Brown definiu como categoria de nível básico porque é o que se aprende mais cedo e é nele que as ações são distintas, as coisas são nomeadas primeiramente, os nomes são mais curtos e usados com mais freqüência. Os demais níveis, 
superiores ou inferiores, são "realizações da imaginação" ("achievements of the imagination").

Berlin e associados, de 1969 a 1977, estenderam a noção de categorias de nível básico ao mostrar que existe um nível universal no qual os seres humanos nomeiam as coisas. Esse nível, por exemplo, para plantas e animais é algo semelhante ao nível do gênero. Conforme o grau de relacionamento de uma cultura com uma determinada categoria pode haver influências que provocam alterações nesse nível universal. Culturas urbanas, por exemplo, possuem categorias menos precisas para árvores que culturas rurais porque as árvores participam menos da vida dos habitantes das cidades. Esse estudo sugere que alguns níveis básicos de categorias surgem da maneira como o ser humano se relaciona com elas e são os mesmos através das culturas.

A maior ruptura dos paradigmas da teoria clássica veio dos trabalhos de Rosch (TAYLOR, 1999). Essa pesquisadora constatou que, ao contrário da teoria clássica, categorias podem ter protótipos, itens que são melhores exemplos que os demais. Ela cita como exemplo que as pessoas consideram o pardal um exemplo melhor de pássaro que o avestruz e o pingüim.

Outra descoberta de Rosch é que a capacidade humana influencia a formação das categorias. Por exemplo, para um homem com 1,70 metros de altura existem muito mais pessoas altas no mundo que para um homem com 1,90 metros de altura, como indica a fussy set theory. A experiência de vida também influencia na categorização. Um exemplo são as categorias $A d H o c$, categorias feitas por um impulso de momento. Diferentes pessoas colocam diferentes coisas na categoria "coisas que deve levar ao acampar" conforme suas experiências, aonde vão, como acampam, etc.

Essas mudanças de paradigma na teoria da classificação influenciaram a Biblioteconomia e a Ciência da Informação, especialmente na construção dos sistemas de classificação.

Os primeiros sistemas de classificação, muitos dos quais utilizados até hoje, inspiraram-se na teoria clássica de Aristóteles e criaram enormes hierarquias de categorias. 
Exemplos são o Dewey Decimal Classification (1976), a Classificação Decimal Universal (1885) e a Classificação da Biblioteca do Congresso Norte-Americano (1900).

Esses sistemas baseados na teoria clássica são mais adequados à preservação de acervos do que a transferência de informação e conhecimento porque retratam bem apenas relações do tipo gênero-espécie e dificultam a criação de novos conceitos a partir da união de conceitos anteriores. Relações não hierárquicas como causa-efeito, produto-produtor e agente-instrumento não são bem representadas nesses sistemas. (LARA, 2001)

Outros sistemas de classificação, que permitem retratar relações não hierárquicas, surgiram quebrando o paradigma da teoria clássica de que existe uma única hierarquia perfeita para mundo. O sistema de classificação por facetas (faced classification) ou multidimensional proposto por Ranganathan ${ }^{7}$ foi o primeiro passo nesse sentido. Esse sistema classifica os assuntos segundo cinco dimensões de categorias diferentes chamadas de facetas.

A noção de faceta é primordial para o desenvolvimento da teoria da classificação já que, ao admitir a possibilidade de abordar diversos pontos de vista, começa a se desvincular dos padrões de divisão do conhecimento calcados exclusivamente nos sistemas filosóficos. A teoria da classificação começa a se desenvolver aproximando-se da Lógica e, ao mesmo tempo, das necessidades mais concretas dos usuários. Esse momento enuncia uma alteração de ênfase nos processos tradicionais da Biblioteconomia, quando a preservação cede espaço para a preocupação em transferência da informação. (LARA, 2001, parte I, pág. 14)

Outra importante evolução são os tesauros, linguagens documentárias cuja ênfase são os objetivos e os conceitos. A Lingüística e a Lógica tem papel fundamental na construção dos tesauros para criar suas redes lógico-semânticas que compreendem

${ }^{7} \mathrm{O}$ conceito de faced classification (classificação por facetas) ou classificação multi-dimensional surgiu pela primeira vez nos trabalhos de Ranganathan para criar o Colon Classification (1933), onde ele propôs um sistema com 5 dimensões básicas para classificação da informação: personalidade (foco ou assunto mais específico), material, energia (atividade, processo ou operação), espaço (lugar) e tempo. (TAYLOR, 1999) 
relações hierárquicas, associativas e de equivalência entre conceitos e estabelecer seu sistema de significação.

Os tesauros constituem o primeiro instrumento documentário de representação que trabalha com a noção de controle do vocabulário. São resultado do reconhecimento de que operamos no universo da linguagem, o que significa dizer que a transferência da informação está atrelada a sistemas de significação. $O$ controle é aqui entendido não sob a perspectiva da padronização, mas como o mecanismo através do qual se busca estabelecer a interação dos sistemas com os seus públicos. Sob esse aspecto, pode-se afirmar que são os tesauros os instrumentos que com maior propriedade podem ser nomeados como linguagens documentárias, já que se caracterizam pela preocupação de realizar efetivamente a atividade de mediação.

(LARA, 2001, parte II, pág. 6)

Os sistemas de classificação, seja os baseados nas teorias clássicas ou os que a contestam, possuem vasta aplicação atualmente. Seus usos abrangem a organização de bibliotecas físicas e on-line, a Web semântica, o processamento de linguagem natural entre outros $^{8}$.

\subsubsection{Dificuldades para organizar informação na Web}

Observando os aspectos cognitivos da teoria da categorização elencados anteriormente é possível compreender as dificuldades que os autores (WURMAN, 1991; ROSENFELD e MORVILLE, 2002; WODTKE, 2003; DIJCK, 2003; BUSTAMANTE, 2004) apontam ao se organizar informação em websites. Essas dificuldades afetam diretamente o design do sistema de organização e estão sintetizadas a seguir.

\footnotetext{
${ }^{8}$ Maiores detalhes sobre os sistemas de classificação e suas aplicações fogem do escopo desse trabalho.
} 


\subsection{Ambigüidade}

Como visto, a classificação de informações se baseia na linguagem humana, que é naturalmente ambígua. "Um mesmo vocábulo pode ter múltiplas interpretações dependendo do contexto onde é apresentado” (BUSTAMANTE, 2004).

A comunicação é equívoca. Somos limitados por uma língua na qual as palavras podem significar uma coisa para uma pessoa e algo bem diferente para outra. Não existe uma forma certa de se comunicar. Pelo menos em sentido absoluto, é impossivel partilhar nossos pensamentos com os outros, pois jamais serão compreendidos de forma exatamente igual. (WURMAN, 1991, pág. 110)

A ambigüidade dificulta o design do sistema de organização em dois níveis: na escolha de um rótulo (nome) que traduza eficientemente o conceito da categoria e na definição de quais elementos pertencem a ela (ROSENFELD e MORVILLE, 2002). Nesse ponto os sistemas de organização e de rotulação se relacionam porque a mudança de um rótulo pode alterar todo o conceito de uma categoria obrigando a readequar os dois sistemas.

\subsection{Heterogeneidade}

O conteúdo da Web é naturalmente heterogêneo. Ele mistura diversos tipos de conteúdos (textos, imagens, vídeos, sons, etc.) em uma infinidade de formatos (html, pdf, ppt, swf, js, etc.). Além disto, o nível de granularidade no acesso a informação também é heterogêneo. Ao contrário das bibliotecas físicas, um website pode indexar ao mesmo tempo um livro, um de seus capítulos, uma de suas tabelas, a coleção a que pertence ou até as livrarias onde está a venda (BUSTAMANTE, 2004).

Essa heterogeneidade dificulta a criação de um sistema de organização único que atenda a todo o website. Por isso é comum se dividir um grande website em pequenos subsites, cada qual com uma organização diferente atendendo diferentes necessidades. 
A natureza heterogênea dos websites torna difícil impor qualquer sistema único de organização estruturada do seu conteúdo. Geralmente não faz sentido classificar documentos em diferentes níveis de granularidade lado a lado. Um artigo e uma revista devem ser tratados diferentemente. Da mesma forma, não deve fazer sentido manusear vários formatos ao mesmo tempo. Cada formato tem suas características únicas e importantes. Por exemplo, nós precisamos conhecer certas coisas sobre imagens, como o formato do arquivo (GIF, TIFF, etc.) e resolução (640 x 480, $1024 \times 768$, etc.). É difícil e muitas vezes errado tentar usar uma abordagem que sirva para todos ao organizar a heterogeneidade do conteúdo de um website. Esta é uma bandeira fundamental de muitas iniciativas empresariais de taxonomia. (ROSENFELD e MORVILLE, 2002, pág. 53)

\subsection{Diferenças de Perspectiva}

Como visto anteriormente, toda organização de informação é afetada pela perspectiva do seu criador, sua cultura e pela sua visão de mundo. WITHROW (2003) afirma que "de um usuário para outro, as categorias podem diferenciar-se significativamente. Algumas categorias são formadas com base em semelhanças visuais (...), enquanto outras categorias podem ser baseadas num conjunto de regras para inclusão e exclusão (...). Diferenças culturais, socialização e efeitos cohort (diferenças baseadas no local onde alguém nasceu) também afetam o processo de categorização, criando mais diversidade em como as categorias são formadas".

WODTKE (2003) corrobora apontando que as experiências de vida e cultura de quem está organizando a informação influenciam diretamente as categorias criadas.

Cada categorizador trás seu conhecimento de vida e prejulgamentos ao processo. A categoria Religião do sistema decimal Dewey tem nove subdivisões, sete das quais são sobre cristianismo. O resto das religiões do mundo está amontoado em uma única subseção: Outras. Línguas têm nove subseções; sete delas cobrem línguas européias. Olhando o sistema decimal Dewey podemos dizer a você em que parte do mundo Melvil Dewey cresceu. 
Durante o projeto, o arquiteto precisa evitar que suas perspectivas influenciem o design do sistema de organização. ROSENFELD e MORVILLE (2002) afirmam que se deve buscar construir um sistema que reflita as perspectivas do usuário, caso contrário estará sacrificando a compreensão da informação.

Outro ponto a se notar é que diferentes usuários podem possuir diferentes perspectivas, conforme seus interesses e conhecimento sobre o assunto do website. Essas diferenças de perspectiva são importantes porque permitem criar várias formas de organização que atendam a diferentes necessidades. "Cada forma de organizar cria nova informação e nova compreensão" (WURMAN, 1991, pág. 78).

$\mathrm{O}$ arquiteto de informação, porém, precisa ter um cuidado especial com a quantidade de diferentes perfis de usuário que pretende atender porque quanto mais perfis existirem maior é a complexidade do sistema de organização e de navegação (DIJCK, 2003).

\subsection{Políticas internas}

A própria maneira com que a informação é organizada sempre destaca alguns de seus atributos enquanto outros ficam escondidos. Assim, por traz das decisões que resultam no modelo de organização não existe apenas a preocupação de atender o usuário. Existem também decisões políticas que visam resolver conflitos de interesse. Supermercados, por exemplo, são organizados de forma a destacar a função de cada produto e ofuscar os seus fabricantes. Se o supermercado alterar sua forma de organização para privilegiar os fabricantes pode aumentar a força da marca deles e consequentemente aumentar-lhes o poder de barganha.

Devido ao poder inerente da organização da informação em formar entendimento e opinião, o processo de design da arquitetura de informação de websites $e$ intranets pode envolver um forte fator político oculto. (ROSENFELD e MORVILLE, 2002, pág. 54)

Balancear a influência das decisões políticas na organização da informação é uma tarefa que requer muita sensibilidade. Ao mesmo tempo em que se deve trazer o foco das 
discussões para as necessidades do usuário é preciso compreender e respeitar as razões por traz de cada decisão política (ROSENFELD e MORVILLE, 2002).

\subsection{Estética}

Além de possuir uma organização compreensível, um website precisa ser agradável, precisa ser bonito. Seus usuários precisam se sentir bem ao utilizá-lo. Segundo NORMAN (2003), um design atrativo aumenta a usabilidade aparente da interface porque faz com que seus usuários pensem de forma criativa e busquem novos modelos mentais quando se deparam com erros. Um design pouco atrativo provoca o efeito inverso, limita a criatividade da mente humana ao se deparar com um erro.

Porém a estética não deve prevalecer sobre a compreensão da informação. A forma deve se adequar ao conteúdo e não o contrário. Esse é um erro comum conforme cita WURMAN (1991, pág. 62):

Embora o papel dos artistas gráficos no fornecimento de informação seja fundamental, a maior parte do currículo das escolas de artes gráficas preocupa-se em ensinar aos alunos como fazer as coisas parecerem agradáveis aos olhos. Isto é posteriormente reforçado pela profissão, que concede prêmios principalmente à aparência e não à compreensibilidade ou mesmo à exatidão. Não existem Oscars, Emmys ou Tonys para quem transforma gráficos e estatísticas em informação compreensivel.

WEST (2001) também reforça a importância do conteúdo prevalecer sobre a forma em um website. Segundo esse autor "muitos designers terão idéias de um design 'legal' $[\mathrm{cool}]$ antes de fazer qualquer outra coisa. Para mim esse é um dos maiores erros que um designer pode cometer. O design 'legal' vai vir, mas o conteúdo/informação é quem deve ditá-lo".

\subsubsection{Esquemas de organização da informação}

A solução apontada por diversos autores (WURMAN, 1991; REISS, 2000; ROSENFELD e MORVILLE, 2002; BRINCK, GERGLE e WOOD, 2002; DIJCK, 2003; 
BUSTAMANTE, 2004) para superar as dificuldades do design do sistema de organização é a utilização de esquemas de organização.

Esquemas de organização são maneiras de se criar categorias a partir da semântica (significado) dos conteúdos a serem categorizados. Cada esquema possui uma regra simples que define a formação das suas categorias. A vantagem em utilizar esses esquemas é que eles permitem que o usuário tenha rapidamente uma visão de como toda a informação está organizada, dando-lhe consistência e previsibilidade (ROSENFELD e MORVILLE, 2002; BUSTAMANTE, 2004).

Segundo WURMAN (1991) a quantidade de esquemas de organização existentes é finita e pequena. Com isso é possível ao arquiteto de informação avaliar todos os possíveis esquemas e escolher os mais adequados ao seu projeto.

A informação pode ser infinita, mas as formas de estruturá-la, não. E se você tiver onde "pendurar" a informação, ela se tornará muito mais útil. Sua escolha será determinada pela história que quer contar. Cada forma permitirá uma compreensão diferente. Dentro de cada uma existem muitas variações, mas reconhecer que as escolhas são finitas e limitadas torna o processo bem menos intimidativo. (WURMAN, 1991, pág. 66)

Unindo-se as propostas de diversos autores (WURMAN, 1991; REISS, 2000; ROSENFELD e MORVILLE, 2002; BRINCK, GERGLE e WOOD, 2002; DIJCK, 2003; BUSTAMANTE, 2004) percebe-se o início da formação de um padrão nos esquemas de organização de informação para websites. Unificando-se o trabalho desses autores é possível identificar nove esquemas de organização divididos em dois grandes grupos, que estão resumidos no diagrama apresentado a seguir. 


\section{Figura 4 - Esquemas de organização da Informação}

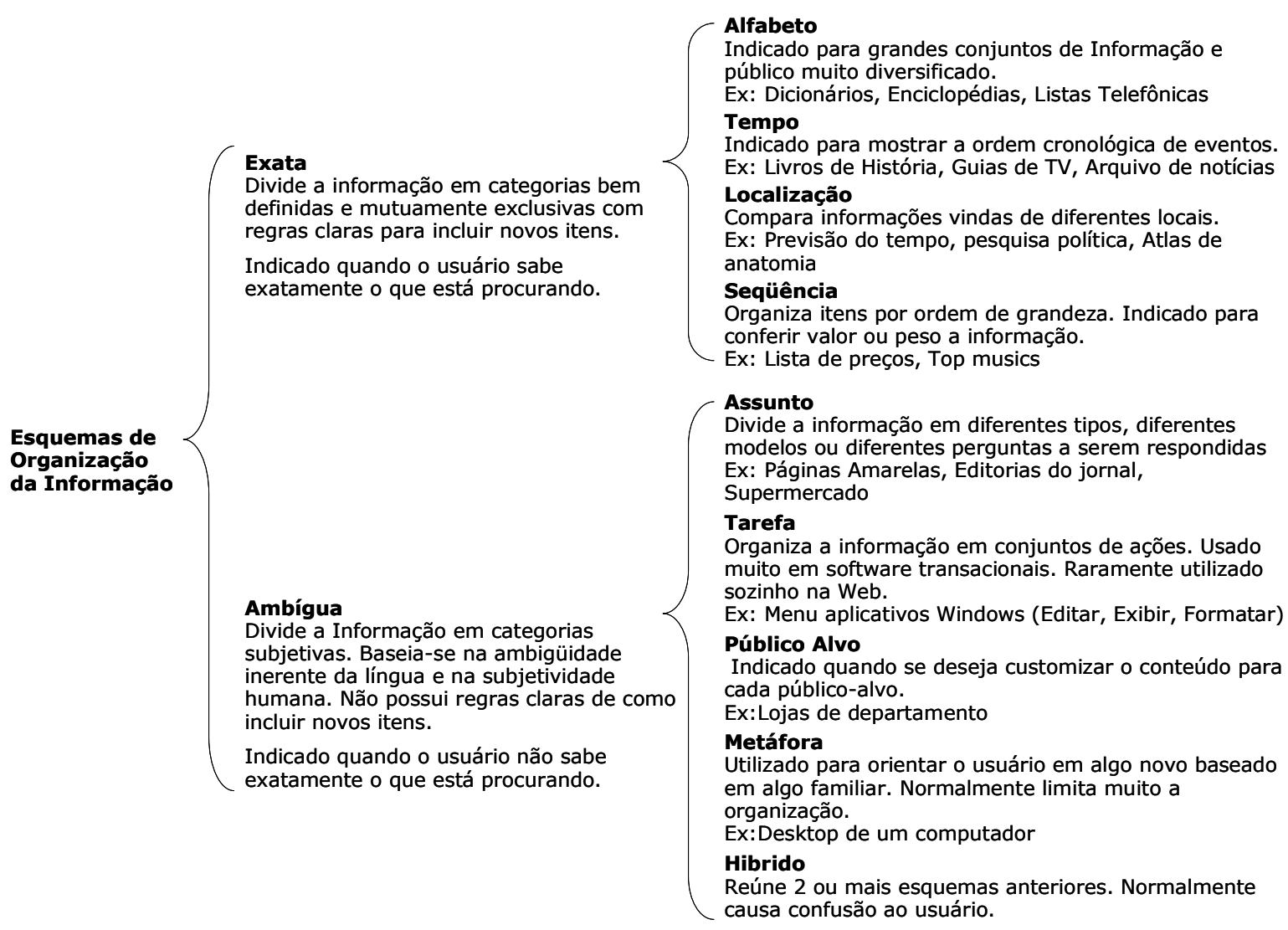

Esses esquemas também podem ser combinados, apresentando ao usuário as informações do website organizadas de várias formas numa estrutura multi-dimensional, como a classificação facetada proposta por Ranganathan. Essas estruturas multidimensionais são facilmente implementadas na Web graças à flexibilidade do hiperespaço e oferecem ao usuário diversas formas de buscar a mesma informação acomodando diversos modelos mentais. Além disso, elas possuem uma quantidade de termos menor no seu vocabulário controlado, o que facilita a manutenção (MORVILLE, 2005).

Os esquemas de organização são apenas uma orientação ao arquiteto de informação. Em um projeto, a decisão de qual esquema utilizar precisa ser validada com o usuário, como sugerem as abordagens do Design Centrado no Usuário da Interação Humano-Computador. Uma técnica bastante sugerida por vários autores para realizar essa validação é a realização de testes de card sorting com o público-alvo do website (REISS, 2000; ROSENFELD e MORVILLE, 2002; DIJCK, 2003; WODTKE，2003; BUSTAMANTE, 2004). No capítulo 4 são apresentados mais detalhes sobre essa técnica. 


\subsubsection{Sistema de Navegação}

O século XV foi marcado pelas grandes navegações portuguesas e espanholas, que contornaram a África e a Índia e cruzaram o Atlântico descobrindo a América. Foi uma época marcada pela coragem dos homens e pelo espírito de aventura. Mas para se navegar por esses mares nunca d'antes navegados foi preciso muito mais que a mera força humana.

As grandes navegações só foram possíveis graças ao aperfeiçoamento das técnicas de navegação e de diversos instrumentos de orientação náutica como a bússola, o astrolábio, a basestilha e o quadrante. Esse salto tecnológico permitiu pela primeira vez que os navegantes conseguissem se orientar com precisão em alto mar e assim ir muito além da Taprobana 9 .

Da mesma forma que nos oceanos, um usuário, ao se mover no espaço hipertextual de um website, precisa de orientação. Sem elementos que orientem seu caminho, ele não consegue chegar ao seu destino e, literalmente, se perde. Fica a deriva no mar do hiperespaço.

A navegação ${ }^{10}$ nos hipertextos introduz uma questão já equacionada como o problema clássico desses sistemas: o utilizador desorienta-se, perde-se no meio de tanta informação, em suma, acontece-lhe aquilo a que Conklin chamou 'perder-se no hiperespaço’ MORGAD (1994)

Estar perdido, seja no mundo virtual, seja no mundo real, é uma sensação angustiante. ROSENFELD e MORVILLE (2002) afirmam que o sentimento de estar perdido é associado à confusão, frustração, insegurança, ira e medo. Um sistema de navegação mal projetado afeta a usabilidade do website porque não orienta o usuário no caminho que precisa seguir para alcançar seus objetivos, causando-lhe o sentimento de estar perdido.

\footnotetext{
${ }^{9}$ A Taprobana, cantada nos versos de Camões em Os Lusiadas, é o antigo Ceilão atual Sri Lanka.

${ }^{10}$ Grifos da autora
} 


\subsubsection{Por que as pessoas se perdem ao navegar em um hipertexto?}

Estar perdido no hipertexto é a situação na qual o usuário não compreende como a informação está organizada, como encontrar o que está procurando ou até se a informação que procura está disponível. ELM e WOODS (apud McKNIGHT e colab. , 1991, pág. 65) descrevem essa situação como "o usuário não tem uma concepção clara dos relacionamentos dentro do sistema ou, não conhece sua presente localização no sistema relativo à estrutura mostrada e acha que é difícil decidir onde seguir dentro do sistema”.

A navegação em hipertextos é comumente comparada à navegação em espaços físicos e é dessa analogia que surgem as principais explicações sobre os processos cognitivos do usuário navegando em espaços hipertextuais. McKNIGHT e colab. (1991) estudaram dois fenômenos cognitivos da navegação em espaços físicos e os aplicaram aos espaços hipertextuais para entender as dificuldades do usuário ao navegar nesse novo meio. São eles os esquemas ou modelos de ambiente genérico e a aquisição de mapas espaciais cognitivos.

\subsection{Esquemas ou modelos de ambientes genéricos}

Os esquemas ou modelos de ambiente genéricos são esquemas pré-concebidos de ambientes físicos que temos em nossa mente adquiridos através da experiência. Todos nós possuímos, por exemplo, um modelo mental de como é uma cidade. Esperamos que ela tenha casas, prédios, ruas, praças, esquinas, etc. Esses modelos existem em diversos níveis de escala, desde o nível de países e continentes até o nível dos cômodos de uma casa (McKNIGHT e colab. , 1991), e a função deles é criar estereótipos sobre a geografia de um ambiente físico desconhecido, algo como "quem já viu uma cidade viu todas". Esse estereótipo inicia a criação do modelo mental do usuário e lhe fornece uma orientação espacial básica para guiar seus comportamentos iniciais ao navegar no novo ambiente.

Porém esses modelos de ambientes genéricos são limitados. Eles não contêm as características individuais do novo ambiente e por isso não oferecem conhecimento além do que é visto com os próprios olhos. Não é possível extrair desses esquemas os detalhes de uma rota dentro do novo ambiente (McKNIGHT e colab. , 1991). 
Em documentos impressos em papel, como livros, jornais e revistas, já existe um esquema genérico aceito sócio-culturalmente, o que facilita muito a navegação dos usuários quando se deparam com um novo documento desse tipo. No caso dos livros, por exemplo, os editores da Itália renascentista estabeleceram no início do século XVII uma série de convenções para a publicação desses materiais, que originaram um esquema genérico que permanece até hoje. Elementos como títulos, prefácio, introdução, sumário, numeração das páginas, índice remissivo são alguns dos componentes desse esquema (MORROGH, 2003). Através da experiência os usuários aprendem esses esquemas o que lhes facilita prever a organização de qualquer livro.

Já nos hipertextos, não existe um esquema genérico tão bem definido quanto nos ambientes físicos ou nos documentos em papel. Um dos motivos para isto é a história recente dos documentos eletrônicos, o que justifica o baixo nível de conhecimento que o público em geral tem dessa tecnologia.

Outro motivo que contribui para a inexistência de um esquema genérico é que o modus opereandi adquirido pelo usuário ao utilizar um sistema em um computador nem sempre se aplica em outros sistemas. A falta de padrões faz com que a manipulação da informação varie de aplicação para aplicação, computador para computador, versão para versão, e atualmente de website para website, dificultando a formação de modelos genéricos (McKNIGHT e colab. , 1991).

Interfaces computacionais padronizadas tendem a diminuir esse tipo de problema. O ambiente computacional criado pelos sistemas operacionais gráficos, por exemplo, definiu padrões para menus, janelas, botões, caixas de textos, listas de opções e diversos outros elementos de interface que juntos formam um ambiente consistente e permitem que o usuário crie um modelo genérico do ambiente com maior facilidade. Na Web não existe uma padronização com a mesma rigidez.

\subsection{Mapas espaciais cognitivos}

Mapas espaciais cognitivos são mapas internalizados na mente humana e que são análogos à disposição física de um ambiente (TOLMAN apud McKNIGHT e colab. , 1991). Eles são adquiridos através das interações do indivíduo com o ambiente e contêm 
os detalhes da posição espacial de cada elemento permitindo que um indivíduo se localize e trace rotas para se locomover.

A aquisição de um mapa espacial cognitivo envolve um processo mental de várias etapas, que vai da identificação de marcos no ambiente até a formação na mente de um mapa geográfico completo (ANDERSON \& WIDCKENS apud McKNIGHT e colab. , 1991).

Existem duas grandes vantagens em se ter um mapa espacial cognitivo de qualquer ambiente, seja de uma cidade ou de um banco de dados. Primeiro existe a oportunidade de planejar e usar atalhos para alcançar os locais desejados. Segundo, e provavelmente mais importante, se o usuário / viajante se distrair de alguma forma e se perder na rota, existe uma grande chance de recuperar seus pontos de apoio e alcançar o destino pretendido, caso ele tenha um mapa espacial cognitivo do ambiente ao invés de ter seu conhecimento simplesmente na forma de uma rota. (EDWARDS e HARDMAN, 1993, pág. 92)

Mapas espaciais cognitivos não têm muita aplicação em documentos em papel, porque todo o espaço informativo é acessível instantaneamente ao leitor. Navegar por um livro é quase uma experiência de tele-transporte. Para alcançar uma página basta virar algumas outras, de modo que o custo de seguir por uma rota errada é muito pequeno tanto em termos de tempo quanto esforço justificando porque seus leitores não desenvolvem um conhecimento de possíveis rotas (McKNIGHT e colab., 1991).

No caso de hipertextos, ao contrário, os mapas espaciais cognitivos têm grande importância na modelagem do processo mental do usuário que navega neles. EDWARDS e HARDMAN (1993) afirmam terem descoberto evidências de que os usuários criam uma representação cognitiva da estrutura hipertextual de modo a formar um mapa espacial cognitivo com a visão geral do ambiente no hipertexto. Eles também notaram que um maior conhecimento da estrutura do hipertexto diminui o sentimento de estar perdido e aumenta a satisfação de uso do sistema. 


\subsubsection{Dificuldades em projetar o sistema de navegação}

Da análise dos processos cognitivos do usuário é clara a analogia entre a navegação no hipertexto e a navegação em ambientes físicos. Nota-se que em ambas o objetivo é alcançar um destino fora do campo de visão do ponto de partida e, para alcançálo, o usuário/navegador se orienta com o auxílio de pontos de referência que determinam a sua posição espacial e a direção que deve seguir.

No mundo real, as referências já existem e fazem parte do ambiente. Árvores, rios, montanhas, estrelas. É infinita a quantidade de pontos de referência que o mundo físico oferece para orientar o navegador em sua trajetória. Porém, em um website, essas referências não existem. Como as placas de uma rua, é necessário criar um sistema de navegação que estabeleça pontos de referência e uma sinalização no ambiente virtual do hipertexto para orientar o usuário no seu caminho.

Dessa forma, o sistema de navegação de um website tem duas funções básicas: indicar ao usuário a sua localização e mostrar o caminho correto que precisa seguir para chegar ao seu destino.

NIELSEN (2000) confirma estas duas funções do sistema de navegação e afirma que, para exercê-las, existem três perguntas fundamentais que esse sistema precisa responder a todo instante para o usuário: "Onde estou?", "Onde estive?" e "Aonde posso ir?".

WODTKE (2003) sugere outras três perguntas fundamentais que também confirmam as duas funções básicas do sistema de navegação: "Estou no lugar certo?", "Ele [o website] tem o que estou procurando?" e "Ele [o website] tem alguma coisa melhor?".

Por fim FLEMING (1998) propõe outras quatro questões para implementar as duas funções básicas do sistema de navegação: “Onde estou?”, “Aonde posso ir?”, "Como chego lá?" e "Como posso voltar para onde eu estava?".

Com relação à primeira função básica do sistema de navegação, indicar para o usuário a sua localização, a dificuldade está em criar no website uma composição 
harmônica dos elementos de navegação para que os usuários consigam, a qualquer instante, determinar a sua localização. NIELSEN (2000) afirma que existem dois níveis de localização que o sistema de navegação precisa apresentar. O primeiro nível mostra a posição do usuário em relação à Web como um todo e identifica em que website o usuário está. O segundo nível posiciona o usuário em relação à estrutura interna do website. Esses dois níveis de localização devem ser apresentados em todas as páginas porque nem sempre o usuário entra no website através da home-page. É muito comum se utilizar um website de busca (por exemplo o Google) para se descobrir as páginas que interessam dentro do website e acessá-las. Dessa forma, a navegação pode começar por uma página interna qualquer e não necessariamente pela sua Home-Page.

Já para a segunda função do sistema de navegação, mostrar o caminho correto, a dificuldade está no projeto dos links visíveis na página. Cada link comunica, por meio do seu rótulo, o que o usuário irá encontrar se clicar nele. A eficiência dessa comunicação está diretamente ligada à capacidade do rótulo em resumir e contextualizar a informação da página que aponta.

FLEMING (1999) afirma qur não existe uma receita simples para se elaborar um sistema de navegação. Porém, essa autora cita uma lista de dez princípios básicos observados em websites com sistemas de navegação de qualidade. São eles:

- Fácil de aprender: O sistema de navegação precisa ser fácil de aprender porque se os usuários perderem muito tempo para entender como utilizá-lo, eles irão abandonar o site.

- Ser consistente: Os usuários, após compreenderem como o sistema de navegação funciona, passam a confiar nele. Um sistema consistente permite que o usuário tenha previsibilidade sobre como será a resposta do sistema antes de executar a ação.

- Prover feedback: O usuário espera que o sistema reaja a cada ação que executar sobre a sua interface porque é através dessas reações que o usuário consegue avaliar se o sistema executou a ação com sucesso. Por isso o 
sistema de navegação precisa sempre dar feedback mostrando-lhe sua posição espacial.

- Presente de diferentes formas conforme o contexto: Para decidir seus movimentos o usuário precisa ver as possíveis rotas. Ser contextualizado é apresentar para o usuário as rotas que lhe interessam conforme o ponto em que se encontra no sistema.

- Oferecer alternativas: Usuários diferentes possuem diferentes estratégias de navegação. O sistema de navegação precisa ser capaz de atender a esses diferentes comportamentos.

- Economizar ações e tempo de utilização: Navegações longas causam frustração no usuário. Por isso, o sistema de navegação precisa sempre manter as rotas curtas e oferecer atalhos, especialmente para usuários experientes.

- Apresentar mensagens visuais claras e no momento adequado: O sistema de navegação precisa ter um visual claro e que guie o usuário em detrimento da estética.

- Possuir rótulos compreensíveis: O sistema de navegação precisa usar rótulos claros, sem ambigüidade, na linguagem do usuário e consistentes com as informações apresentadas.

- Estar em sintonia com o propósito do website: A abordagem do sistema de navegação depende muito dos objetivos do website e das experiências do usuário, assim o design do sistema de navegação deve auxiliar o usuário a seguir esses objetivos.

- Suportar os objetivos e comportamentos do usuário: O sistema de navegação precisa auxiliar os usuários a executarem suas tarefas da forma que estão acostumados a fazê-las. 
Nota-se nesses princípios de FLEMING a preocupação de que o sistema de navegação reflita os objetivos, as experiências e comportamentos do usuário, o que reforça a preocupação em se seguir uma abordagem de Design Centrado no Usuário ao projetar esse sistema.

\subsubsection{Flexibilidade X Confusão}

A principal característica do hipertexto é que cada página pode ter links apontando para quantas e quais outras páginas se desejar. Não existem limites para a quantidade de links que uma página de hipertexto pode ter. Assim, o arquiteto de informação tem uma ferramenta extremamente flexível, que lhe dá a liberdade de montar as estruturas de organização e os sistemas de navegação que desejar.

Porém, uma quantidade excessiva de links confunde o usuário. Segundo GARRETT (2002b), o usuário, ao se deparar com uma nova página, percorre os olhos por todos os links existentes tentando encontrar o que melhor atende sua intenção. Se uma quantidade excessiva de links é apresentada, o esforço cognitivo para encontrar o link correto é maior, aumentando a probabilidade de confusão.

Na prática, cabe ao arquiteto de informação enfrentar essa dificuldade balanceando o grau de flexibilidade com o grau de confusão em cada página. Tipicamente, tarefas mais críticas devem ter uma navegação com menos opções de modo que o usuário consiga focar melhor sua atenção (ROSENFELD e MORVILLE, 2002).

\subsubsection{Navegação Social}

ROSENFELD e MORVILLE (2002) definem como navegação social (social navigation), o valor derivado da observação da navegação de outros usuários. A idéia consiste em apresentar para um usuário o que outros usuários com os mesmos interesses encontraram ao navegar pelo website.

Talvez o exemplo mais famoso de navegação social está no filtro colaborativo da livraria virtual Amazon (www.amazon.com). Nesse website, cada página que detalha um produto possui uma lista de links chamada "Customers who bought this also bought" 
("Clientes que compraram isto também compraram") na qual são apresentados produtos que interessaram a outros usuários na mesma situação. SEYBOLD (2000) estima que cerca de $10 \%$ dos pedidos feitos a Amazon vem dessas sugestões de links.

A navegação social tem grande valor porque cria correlações entre os conteúdos baseadas nos interesses dos usuários e não nas suposições do arquiteto de informação. Por isso é uma boa ferramenta para superar as dificuldades do projeto do sistema de navegação, especialmente para se melhorar a contextualização. De fato, como aponta a abordagem do Sense-Making, o aparente caos do caminho construtivista de um usuário resulta uma padronização que pode ser compartilhada para auxiliar outros usuários em seus processos de busca de informação.

\subsubsection{Elementos do Sistema de Navegação}

ROSENFELD e MORVILLE (2002) classificam os elementos que compõem o sistema de navegação em dois subsistemas: o sistema de navegação embutido e sistema de navegação suplementar. O primeiro é composto por elementos apresentados junto com o conteúdo da página, e tem a função de contextualizar o usuário e oferecer flexibilidade de movimento. O segundo é externo a hierarquia do website e provê caminhos complementares para encontrar o conteúdo e completar as tarefas. A Tabela 5 detalha esses elementos.

Tabela 5 - Elementos do Sistema de Navegação

\section{Sistema de Navegação Embutido}

\section{Logotipo}

Tem a função de identificar o website e mostrar a sua posição em relação à Web como um todo. Como se pode entrar em um website por qualquer página, é importante que todas as páginas contenham o logotipo para que o usuário identifique em que website se encontra.

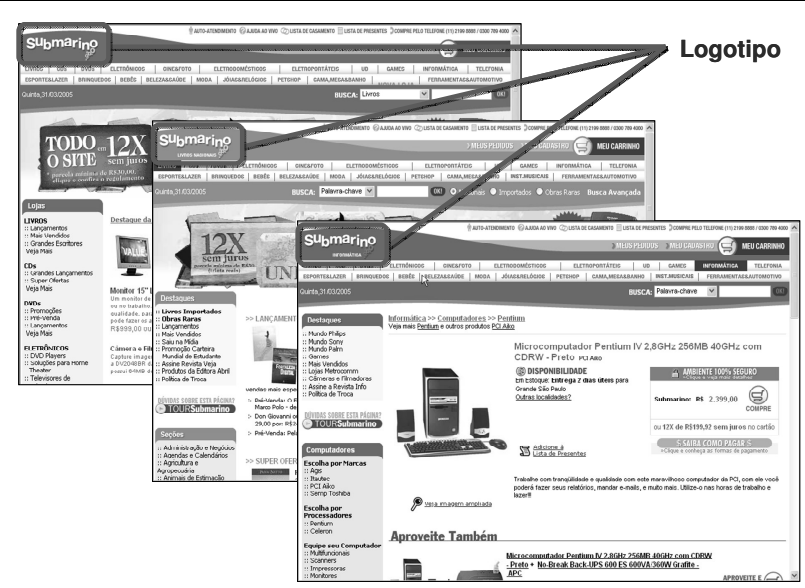

Logotipo presente em diversas página na loja virtual Submarino (www.submarino.com.br) 


\section{Barra de Navegação Global}

Barra com uma seqüência de links para as áreas chaves do website, as grandes categorias do sistema de organização.

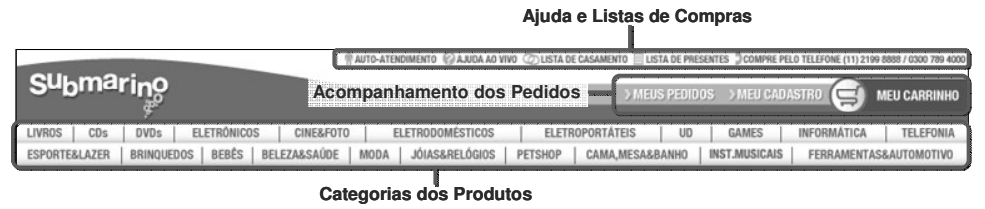

Barra de navegação global da loja virtual Submarino (www.submarino.com.br)

\section{Menu local}

Sua função é estabelecer uma navegação local, mostrando links para páginas que estão próximas na estrutura do website à página que está sendo visitada, como páginas irmãs, filhas e pais.

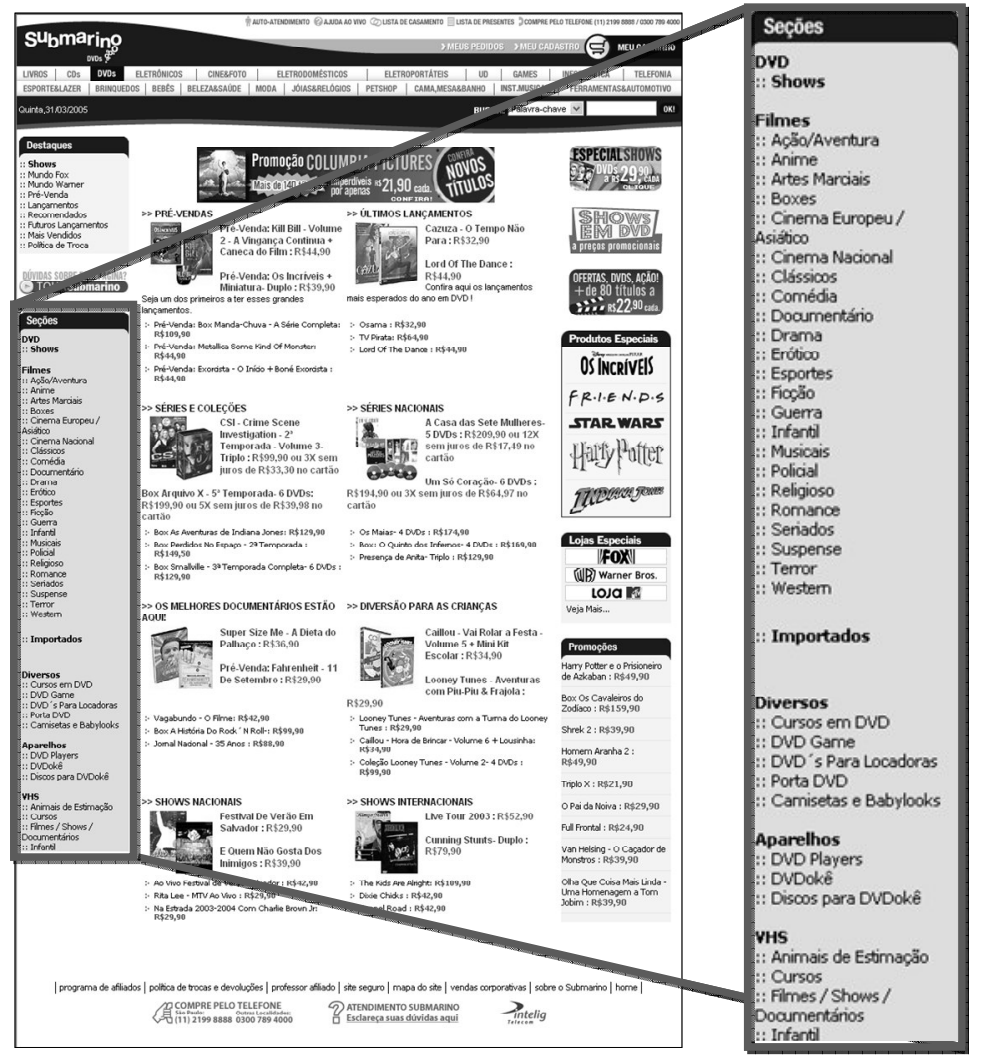

Menu local da seção de DVDs da loja virtual Submarino (www.submarino.com.br)

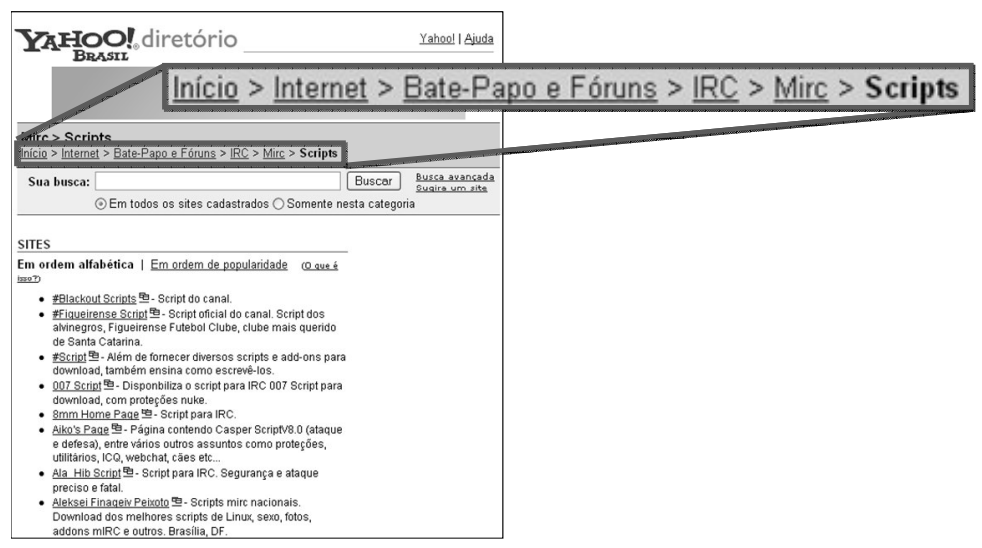

Bread Crumb no website Yahoo! (www.yahoo.com.br)

\section{Bread Crumb}

É uma lista de elementos (links) separados por algum caractere (normalmente $>$, : ou | ) ou gráfico (normalmente uma seta para a direita). Tem a intenção de informar o usuário onde ele se encontra na estrutura do website e prover links para os níveis hierárquicos imediatamente superiores. 


\section{Cross Content}

É uma lista de links relacionados ao conteúdo da página atual. Podem oferecer um nível maior de profundidade ou atalhos para grandes movimentos laterais.

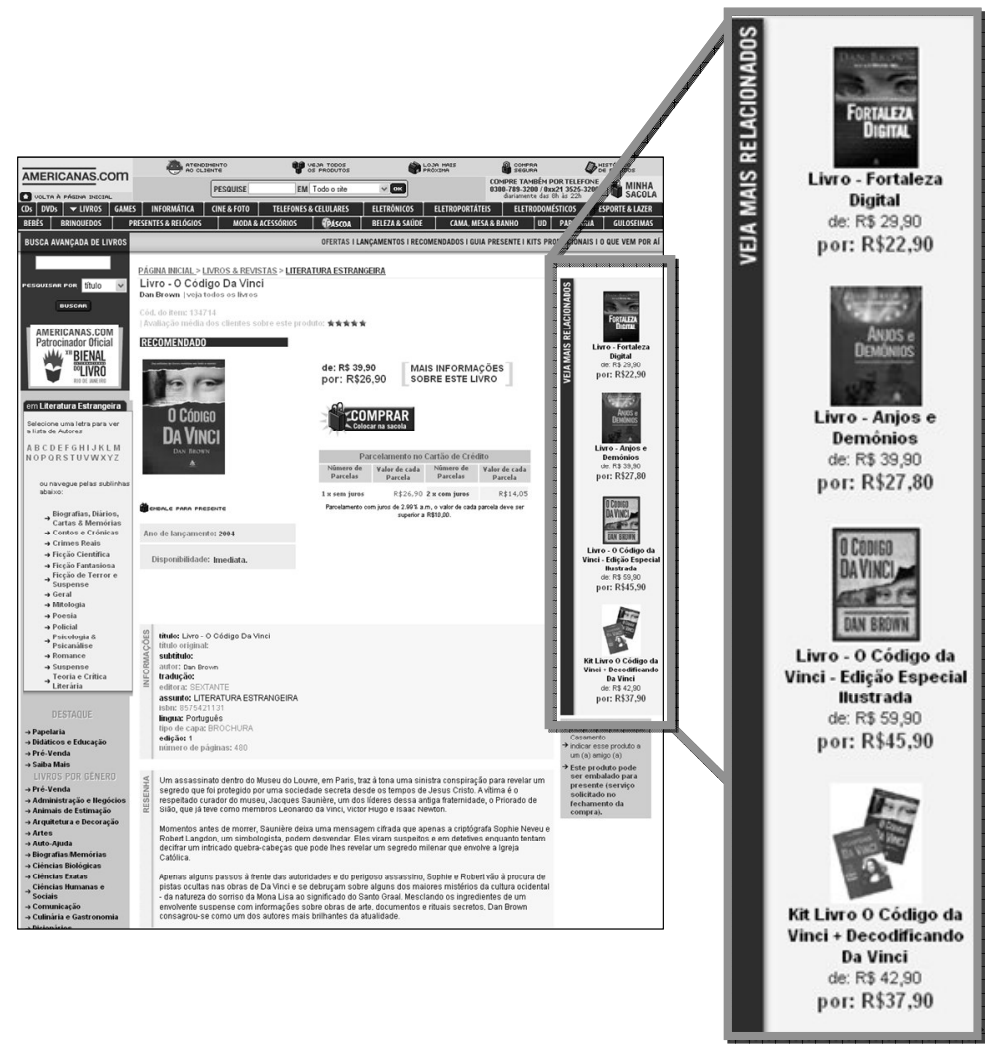

Cross contents na loja virtual Americanas.com (www.americanas.com.br)

Sistema de Navegação Remoto

\section{Mapa do Site}

Tem a função de apresentar toda a estrutura analítica do website e permitir acesso direto a qualquer página.

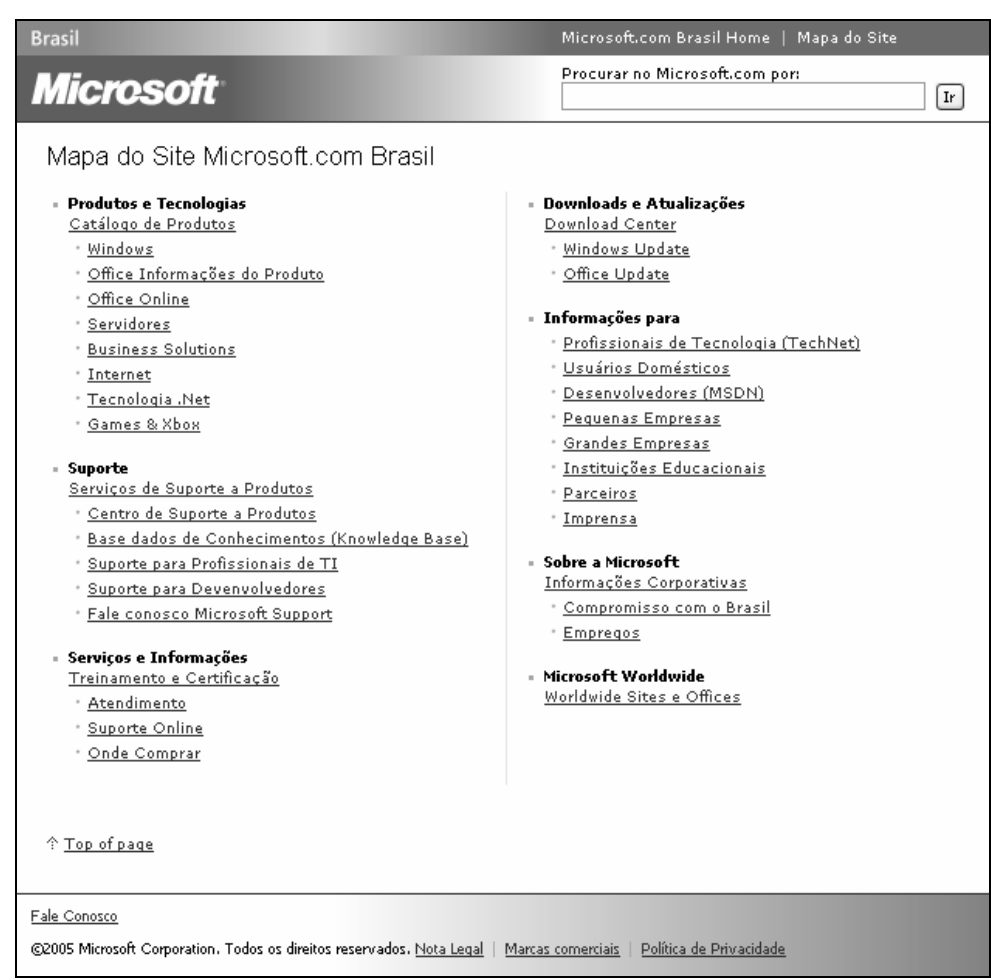

Mapa do site da Microsoft (www.microsoft.com.br) 


\section{Índice Remissivo}

São listas de palavras chaves, em ordem alfabética, relacionadas ao conteúdo do website. Assemelham-se aos índices remissivos dispostos no final dos livros.

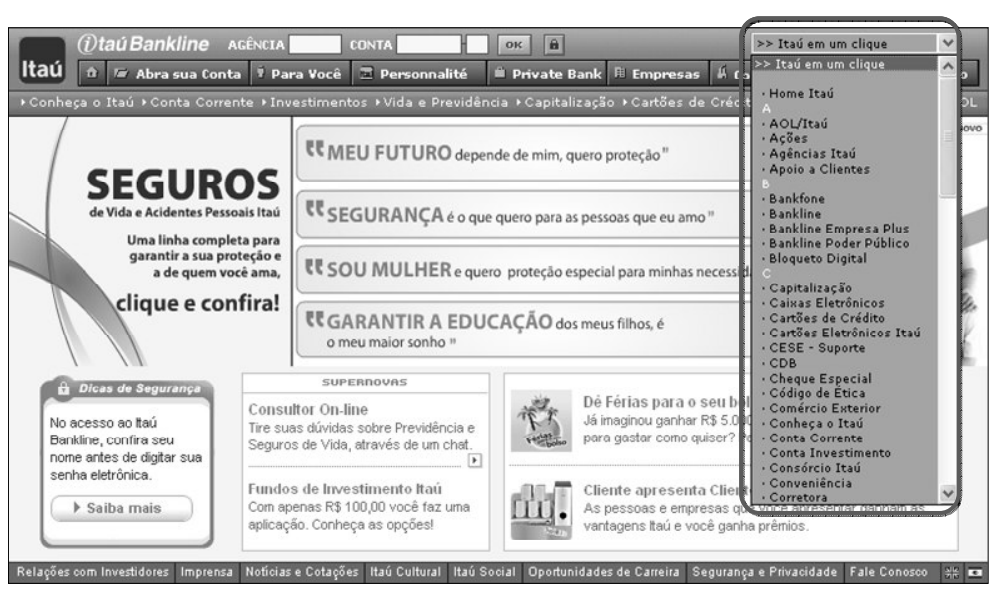

Índice remissivo no website do Banco Itaú (www.itau.com.br)

A ausência de padronização dos elementos de interface é mais uma dificuldade no projeto do sistema de navegação. Não existe ainda um esquema genérico para websites como os existentes nos documentos impressos. Um esquema genérico determinaria um conjunto de regras conhecidas e compartilhadas tanto pelo arquiteto de informação quanto pelo usuário, o que estabeleceria uma sintaxe para a linguagem hipertextual da Web. ENGEBRETSEN (apud NOCI e SALAVERRÍA, 2003) aponta que a ausência dessa sintaxe desorienta o usuário e compromete a sua compreensão da informação apresentada.

Deve-se ter em conta que a falta de regras no hipertexto pode chegar ao ponto de impossibilitar a comunicação. A novidade do hipertexto ocasiona todavia uma escassez de regras gramaticais e discursivas acordadas entre autor e leitor (...). Se diante de um hipertexto o leitor ignora onde se encontra e como deve interpretar a leitura seqüencial de certos nós, a informação adquirida pode carecer de completo sentido para ele. Dito de outro modo: se o leitor desconhece a sintaxe de um hipertexto é impossível que o consiga ler. (NOCI e SALAVERRÍA, 2003)

Inspirados principalmente nas teorias da Interação Homem-Computador, diversos autores (ROSENFELD e MORVILLE, 2002; REISS, 2000; NIELSEN, 2000; WODTKE, 2002; INSTONE, 2003) propõem diretrizes e recomendações para o design de cada um dos elementos do sistema de navegação. Não são regras exatas e sua aplicação ainda dependem muito da experiência e bom senso do arquiteto de informação. Mas elas são 
uma ferramenta de grande valia porque apresentam orientações para um bom design e iniciam a criação dessa sintaxe para o hipertexto na Web.

Porém ainda está longe a consolidação dessa sintaxe. Criá-la envolve estabelecer regras que detalhem como cada elemento do sistema de navegação deve se comportar em cada possível situação do usuário. Além disso, essas regras precisam ser conhecidas e compartilhadas tanto por projetistas quanto usuários, ou seja, precisam ser padrões legitimados.

A flexibilidade, heterogeneidade e descentralização da Web enquanto mídia é provavelmente o maior obstáculo para criar essa sintaxe. Sistemas operacionais gráficos, por terem características opostas, conseguiram uma padronização maior de suas interfaces e já possuem indícios de terem uma sintaxe. Nas aplicações desenvolvidas para o Microsoft Windows, por exemplo, é amplamente disseminado o uso comum de algumas teclas de atalho (Ctrl-C, Ctrl-V, F1, etc.) e itens de menu (File ou Arquivo, Edit ou Editar, Format ou Formatar, Help ou Ajuda, etc.)

A aplicação das diretrizes e recomendações existentes atualmente e o seu aperfeiçoamento ao longo do tempo poderá criar a sintaxe para o hipertexto na Web.

\subsubsection{Sistema de Rotulação}

\section{Se não agüenta a vara, peça cacetinho!}

Quem já passou o carnaval na Bahia atrás dos seus famosos trios elétricos ouviu essa frase inúmeras vezes. Mas o que ela significa? Antes de lhe atribuir qualquer interpretação maliciosa, vale conhecer um pouco melhor o "dialeto local". Segundo o Dicionário de Bainês (LARIÚ, 1992) vara é um pão de sal de $200 \mathrm{~g}$ e cacetinho é um pão de sal pequeno, de apenas $50 \mathrm{~g}$. Assim a frase sugere apenas uma simples medida para evitar desperdícios! 
É claro que quando Bell Marques ${ }^{11}$ grita esta frase do alto do seu trio elétrico, ele aproveita a ambigüidade de interpretação que a frase sugere para brincar com os foliões em festa. Essas formas criativas de comunicação, que exploram as particularidades da língua, são excelentes para se fixar uma mensagem na mente do receptor e é um bom artifício, intencionalmente usado por artistas e profissionais de comunicação.

Porém, na arquitetura de informação de um website, formas criativas como essas tendem a ser especialmente prejudiciais à usabilidade. Um rótulo ou um ícone ambíguo causa erros de interpretação e todo o trabalho efetuado na elaboração do sistema de organização e navegação pode se perder simplesmente porque o arquiteto utilizou rótulos que o usuário não compreende.

Devido à riqueza da língua, caracterizada pelas diferentes interpretações que cada palavra tem e pelas diversas palavras que podem traduzir o mesmo conceito, construir o sistema de rotulação é provavelmente a tarefa mais difícil em um projeto de arquitetura de informação.

Projetar rótulos eficientes é talvez o aspecto mais difícil da arquitetura de informação. A língua é simplesmente tão ambígua que você sempre sente que pode melhorar um label. Sempre existem sinônimos e homônimos para se preocupar e diferentes contextos influenciam nosso entendimento sobre o que um termo em particular significa.

(ROSENFELD e MORVILLE, 2002, pág. 92)

\subsubsection{0 que são rótulos?}

Um rótulo ou termo (em inglês utiliza-se a palavra label) é um símbolo lingüístico utilizado para representar um conceito. O objetivo de um rótulo é comunicar o conceito eficientemente, ou seja, comunicar o conceito sem ocupar muito espaço na página e sem demandar muito esforço cognitivo do usuário para compreendê-lo. Nos websites os

11 Bell Marques é vocalista da banda Chiclete com Banana, que tradicionalmente se apresenta em trios elétricos no carnaval de Salvador, Bahia. 
rótulos são empregados nos títulos de páginas, nas opções do sistema de navegação, nos links contextualizados dentro das páginas e nos meta-dados utilizados na indexação das páginas para o sistema de busca. (ROSENFELD e MORVILLE, 2002)

Um rótulo pode ser textual (ou verbal), quando composto por uma ou mais palavras, ou não textual, quando composto de imagens, sons ou gestos. Em websites, o tipo mais comum de rótulos não textuais são os ícones, pequenas imagens que representam conceitos.

Associar rótulos a conceitos é um ato natural dos seres humanos e que nos permitiu criar as línguas e nos comunicarmos. Uma língua, numa visão simplificada, é apenas uma relação de termos na qual atribuímos a cada conceito um símbolo (termo) que o representa. No caso das línguas faladas esse símbolo é uma imagem acústica, é o som pronunciado para cada palavra. Mais tarde, com a criação da escrita, surgiram os alfabetos que traduziram essa imagem acústica em sinais gráficos.

Essa relação de termos que forma a língua é um produto social, o que permite que ela seja utilizada como instrumento de comunicação por uma comunidade (SAUSSURE, 1995; DUBOIS e colab., 1993).

SAUSSURE (1995) define como signo lingüístico a combinação do conceito (significado) e do símbolo que o representa (significante) e afirma que essa ligação entre eles é arbitrária.

Assim, a idéia de "mar" não está ligada por relação alguma interior à seqüência de sons $m-a-r$ que lhe serve de significante; poderia ser representada igualmente bem por outra seqüência, não importa qual; como prova, temos as diferenças entre as línguas e a própria existência de línguas diferentes: o significado da palavra francesa boeuf ("boi”) tem por significante bfranco-germânica, e o-k-s (Ochs) do outro. (SAUSSURE, 1995, pág. 81)

Esse autor ainda apresenta duas características opostas do signo: sua imutabilidade e sua mutabilidade. 
Embora, em uma língua qualquer, a escolha do significante que representa o significado seja arbitrária, ela é imposta à comunidade praticante da língua tornando-a imutável a cada um dos seus indivíduos. Existem quatro razões para essa imutabilidade: o seu caráter arbitrário, a multidão de signos necessários para constituir qualquer língua, o caráter demasiado complexo do sistema e a resistência da inércia coletiva a toda renovação lingüística.

Porém o tempo, elemento que assegura a continuidade da língua, também atua como um elemento que acumula as forças sociais que agem sobre ela para adequá-la a realidade da massa falante. Essa ação do tempo em grandes dimensões é a causa da diversidade geográfica de línguas e dialetos que temos no mundo e, em pequenas dimensões, a causa da formação das gírias. Comunidades distantes geograficamente ou socialmente introduzem diferentes inovações na língua, que, acumuladas ao longo do tempo, geram sua mutabilidade.

A gíria, em especial, é um dialeto social empregado por uma determinada camada da sociedade para se opor as demais. Seu objetivo é ser compreendida apenas pelos membros do grupo. Para criar seus novos signos, a gíria utiliza metáforas, sinônimos parciais e empréstimos de termos oriundos de outros dialetos e línguas estrangeiras (DUBOIS et al., 1993).

\subsubsection{Dificuldades no projeto do sistema de rotulação}

As principais dificuldades no projeto dos sistemas de rotulação apontadas por diversos autores (REISS, 2000; ROSENFELD e MORVILLE, 2002; WODTKE, 2003; BUSTAMANTE, 2004) advém dos próprios mecanismos que formam as línguas e de toda a sua subjetividade e ambigüidade. Essas dificuldades estão sintetizadas a seguir.

\subsection{Conseguir falar na linguagem do usuário}

A grande dificuldade no projeto de rótulos é conseguir utilizar a mesma linguagem do usuário (ROSENFELD e MORVILLE, 2002). Um usuário comum normalmente vive em um ambiente diferente do arquiteto, que o leva a conviver com gírias, expressões 
técnicas e até dialetos diferentes (WODTKE, 2003). Compreender essa linguagem requer, por parte do arquiteto, uma imersão no dia-a-dia do usuário.

Também é comum que a empresa (ou outra entidade que estiver contratando o projeto do website) tenha sua linguagem própria interna, sua gíria, e queira utilizá-la na criação dos rótulos. REISS (2000) acredita que não existe nenhuma organização que não tenha inventado sua linguagem própria interna. Porém essa linguagem normalmente é incompreensível para quem não vive a sua realidade interna de forma que deve-se evitar utilizá-la ao elaborar o sistema de rotulação.

\subsection{Superar a ausência de feedback}

Numa conversa comum, os seres humanos dispõem de uma infinidade de recursos de feedback que os auxiliam a verificar se a mensagem está sendo corretamente assimilada. Alguns exemplos desses recursos de feedback são os gestos, o posicionamento do corpo, a entonação de voz. Além disso, como a comunicação numa conversa ocorre de forma síncrona, a qualquer momento pode-se fazer perguntas para solucionar as dúvidas obtendo-se respostas de imediato (ROSENFELD e MORVILLE, 2002).

Num website, a comunicação entre o arquiteto e o usuário ocorre apenas através da interface do website (a imagem do sistema) e de forma assíncrona. O pouco feedback que o arquiteto recebe provém da medição do acesso às páginas (page views), e-mails de dúvidas, sugestões e reclamações, e da análise do $\log$ do mecanismo de busca. E nenhum destes feedbacks ocorre em tempo real.

Essa ausência de feedback torna difícil ao arquiteto de informação saber se e como a imagem do seu sistema está sendo corretamente compreendida pelo usuário e, em caso de erro, quais correções precisa fazer.

\subsection{Eliminar ambigüidades}

Como a linguagem humana é ambígua, ao procurar por um conteúdo em uma lista de categorias, o usuário pode se deparar com duas ou mais categorias onde o item que procura pode estar contido. Um smart phone, por exemplo, pode estar nas categorias 
"telefone celular", "computador de bolso (handheld)" e "câmera fotográfica" simplesmente porque esse aparelho unifica essas três funções.

REISS (2000) recomenda, para evitar ambigüidades como essa, criar categorias mutuamente exclusivas, sem intersecções. Porém na prática criar categorias com essas características nem sempre é possível. Assim, uma alternativa sugerida por WODTKE (2003) é duplicar os links. Coloca-se links para o mesmo conteúdo dentro de todas as categorias que geram dúvidas.

Os quase-sinônimos, palavras que têm um significado muito próximo, são outro tipo de ambigüidade. Muitas vezes a diferença de significado entre algumas palavras é tão sutil que apenas os especialistas conhecem. Por exemplo, a diferença entre os rótulos "Congresso" e "Conferência" é muito técnica e por isso desconhecida do público em geral. Nesses casos, pode-se unir os dois rótulos em uma única categoria como em "Congressos e Conferências".

Websites grandes, que abrangem vários públicos-alvos e assuntos diferentes, também podem ter problemas de ambigüidade causado por homonímias. Criar sub-sites focados em poucos públicos-alvos e em poucos assuntos é uma maneira de resolver isso. CAMPOS e colab. (2004) citam que problemas como homonímia e ambigüidades reduzem-se muito quando se estreita a abrangência do assunto.

\subsection{Manter a consistência}

Ser consistente é talvez a mais importante diretriz da Usabilidade e se aplica diretamente na criação dos rótulos de um website. Porém criar um sistema de rotulação consistente é complexo porque essa consistência precisa ocorrer em diferentes níveis.

ROSENFELD e MORVILLE (2002) citam seis níveis nos quais essa consistência precisa ser observada nos rótulos: 
- Estilo: consistência no uso de caixa-alta e caixa-baixa e da pontuação.

- Apresentação: consistência na aplicação de fontes, cores, tamanhos de letra e espaços em branco que reforçam o agrupamento dos labels.

- Sintaxe: uniformidade na sintaxe dos rótulos (grau, número, gênero, tempo verbal, etc.). Usar, por exemplo, apenas verbos no infinitivo ou apenas substantivos.

- Granularidade: equalização na especificação de cada rótulo evitando misturar, no mesmo nível, rótulos com significado abrangente (ex: Restaurantes) com rótulos com significado estreito (Ex: Cantinas italianas).

- Completude: cobrir completamente o escopo definido dos rótulos. Por exemplo, se uma loja de roupas possui as categorias "calças", "gravatas" e "sapatos" sente-se a falta da categoria "camisas", se uma interface possui os comando "frente", "trás" e "direita" sente-se a falta do comando "esquerda".

- Audiência: manter a consistência dos rótulos no vocabulário da audiência, sem misturar rótulos de públicos diferentes. Por exemplo, não misturar termos científicos com populares. Caso o website tenha mais de uma audiência, deve-se considerar a criação de sistemas de rótulos diferentes para cada uma.

Outro nível de consistência que precisa ser observado é a sinonímia. Qualquer língua é repleta de sinônimos e quase sinônimos. "Farol" é sinônimo de "semáforo", “início" é quase sinônimo de "começo". É preciso também manter a consistência no nível dos sinônimos, tratando os mesmos conteúdos pelos mesmos nomes. O estreitamento do escopo do website convergindo para poucos públicos-alvos e assuntos é uma saída para resolver a inconsistência no nível da sinonímia (ROSENFELD e MORVILLE, 2002; DIJCK, 2003). 


\subsubsection{A padronização dos rótulos}

Da mesma forma que os elementos do sistema de navegação e pelos mesmos motivos, utilizar rótulos padronizados é importante no design do sistema de rotulação. Rótulos padronizados criam um nível de consistência entre os diferentes websites na Internet permitindo que o usuário possa aplicar o modelo mental que desenvolveu para um website em vários outros.

A Web já começa a criar alguns rótulos padrões para os websites, que nasceram do mimetismo dos próprios desenvolvedores de websites. A seguir são listados alguns dos rótulos padrões mais comum nos websites em inglês e suas traduções para o português (ROSENFELD e MORVILLE, 2002; BUSTAMANTE, 2004):

- Main, Main Page, Home, Home-Page, Página Inicial.

- Search, Find, Busca, Buscar.

- Sitemap, Contents, Table of Contents, Index, Mapa do Site.

- Contact, Contact Us, Contact Webmaster, Feedback, Contate-nos, Fale Conosco, Entre em contato.

- Help, FAQ, Frequently Asked Questions, Ajuda, Dúvidas, Tire suas Dúvidas.

- News, What's New, Notícias, Últimas Notícias.

- About, About us, About < company name >, Who We Are, Quem Somos, Sobre a <empresa $>$.

\subsubsection{4 Ícones como rótulos}

Ícones são pequenas imagens usadas para representar conceitos em substituição aos os rótulos textuais. $\mathrm{O}$ advento dos sistemas operacionais gráficos trouxe os ícones para as interfaces computacionais como um recurso para melhorar a sua usabilidade.

Segundo HORTON (1994), os ícones podem ser utilizados nas interfaces computacionais para representar conceitos visuais e espaciais, para poupar espaço na tela, para acelerar a localização de um rótulo, para obter reconhecimento imediato do conceito 
pelo usuário, para melhorar a memorização da interface e para facilitar o uso para pessoas com dificuldade de leitura (analfabetos, semi-analfabetos e estrangeiros).

A criação de um sistema de rotulação baseado em ícones é mais complexa que a de rótulos textuais porque eles constituem uma linguagem muito mais limitada que os textos. ROSENFELD e MORVILLE (2002) apontam essa limitação e afirmam que por causa dela os ícones são usados tipicamente nos sistemas de navegação ou em sistemas de organização pequenos porque a lista de opções é reduzida.

COOPER e REIMANN (2003) citam que os ícones são facilmente reconhecidos pelos seres humanos, porém são menos precisos e claros. O ícone é ambíguo enquanto o usuário não aprende seu significado, mas uma vez aprendido, ele não o esquece facilmente e seu reconhecimento é mais rápido. Por isso os ícones são indicados para usuários freqüientes.

As dificuldades vistas anteriormente para o projeto de sistemas de rotulação baseados em rótulos textuais também se aplicam aos sistemas baseados em ícones. No projeto de ícones precisa haver também um cuidado especial com o contexto em que as imagens são apresentadas. HORTON (1994) aponta que uma mesma imagem pode ter significados muito diferente conforme a situação em que é visualizada. Ícones ou textos adjacentes, rótulos relacionados, janelas e outros objetos no ambiente onde o ícone é apresentado são os principais elementos que criam contexto e interferem na interpretação do ícone, podendo reforçar ou reverter totalmente seu significado. 


\section{Investigação teórica das metodologias de projetos de arquitetura de informação de websites}

Poucos anos depois do surgimento da Web, houve em todo o mundo uma corrida desenfreada das empresas para criar websites e negócios na Internet. Apelidada de "a bolha da Internet”, essa corrida iniciou-se em 1995, quando a Netscape ${ }^{12}$ fez seu IPO $^{13}$, e se estendeu até 2001, quando planos de negócio mal sucedidos provocaram a falência de diversas empresas com negócios na Web. Porém, apesar das enormes perdas financeiras, graças a essa "corrida do ouro" trilhões de dólares foram investidos na Internet, o número

\footnotetext{
${ }^{12}$ A Netscape Network é uma empresa norte-americana pioneira que produziu o o Netscape Navigator, um browser que foi lider de mercado no início da Web.

${ }^{13}$ IPO é a sigla em inglês para oferta inicial pública de ações. Ela ocorre quando uma empresa emite ações para serem negociadas em bolsas de valores.
} 
de usuários da rede cresceu muito e novas tecnologias e websites conceituados foram desenvolvidos e permanecem até hoje.

No início da bolha, era comum que os websites fossem desenvolvidos sem qualquer metodologia. Um único profissional "faz tudo" chamado Webmaster conhecia as principais ferramentas e linguagens de programação para Web e assumia sozinho todas as etapas dos projetos de websites (LARA FILHO, 2003; MEMÓRIA, 2006). Essa prática evoluiu e atualmente os projetos de websites seguem metodologias multi-disciplinares e que envolvem diversas áreas do conhecimento e profissionais com diferentes habilidades (DUYNE e colab. apud MEMÓRIA, 2006; MARTINEZ, 2002; GARRETT, 2003).

Segundo MEMÓRIA (2006), de forma geral, as atuais metodologias multidisciplinares de projetos de websites apresentam três grandes fases:

- Fase de Compreensão: na qual se pesquisa as necessidades dos usuários, os objetivos do website e se define o escopo e requisitos do projeto.

- Fase de Concepção: na qual são definidas as regras de organização e navegação, o estilo gráfico, a linha editorial e todos os demais elementos que formam o modelo mental do website.

- Fase de Construção: na qual o conteúdo do website é redigido e organizado, o design gráfico é finalizado, as páginas Web, o banco de dados e os serviços são codificados e o website é disponibilizado para uso.

MELLY (2003) corrobora com essa divisão em fases e apresenta um diagrama (Figura 5) no qual ilustra as principais atividades de um projeto de um website. 
Figura 5 - Etapas do projeto de um website (MELLY, 2003)

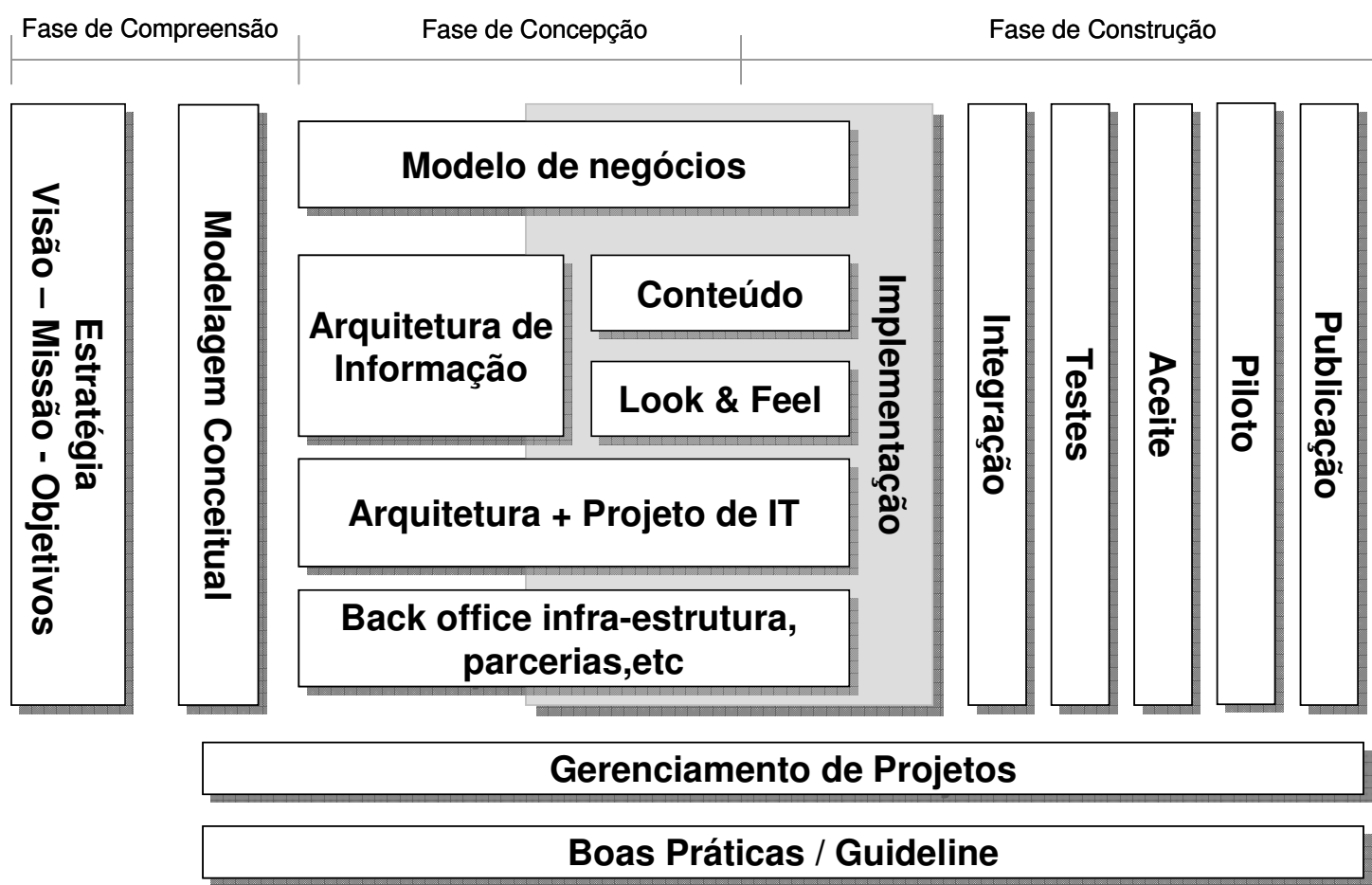

A Moebius, também chamada de Web Progressiva ou P-Web, é outra metodologia de projetos de websites desenvolvida por ALMEIDA e OLIVEIRA (2002) e focada mais no detalhamento do público-alvo, do mercado, do produto e da concorrência para estabelecer um planejamento estratégico.

Essa metodologia apresenta quatro fases: Entender, Planejar, Executar e Monitorar. As três primeiras fases são semelhantes das fases de Compreensão, Concepção e Construção das metodologias de MELLY (2003) e MEMÓRIA (2006). A quarta etapa da metodologia tem a função de acompanhar o desempenho do website e medir seus resultados para executar melhorias e correções. "Na realidade, um projeto começa na prática após o seu lançamento. É a partir desse ponto que os dados começarão a ser colhidos e analisados; é a partir desse momento que todo o planejamento deve ser validado baseando-se nos resultados que ele está proporcionando." (ALMEIDA e OLIVEIRA, 2002, pág. 135).

No diagrama de MELLY (2003) é possível observar a presença da Arquitetura de Informação como uma das atividades necessárias para o projeto de website. Ela está na 
fase de Concepção por ser responsável pela definição da estrutura de organização das informações, sobre a qual todas as demais partes do website irão se apoiar. Pelos mesmos motivos, na metodologia Moebius a Arquitetura de Informação se localiza na fase Planejar.

A Arquitetura de Informação inicia, segundo MELLY (2003), com o fim da atividade Modelagem Conceitual, a qual teve a função de elaborar o planejamento estratégico do website. Sua função é materializar as idéias e conceitos definidos nessa modelagem criando as regras de organização e navegação do ambiente informacional do website e o modelo de interação do usuário com esse ambiente.

Como visto no capítulo 3, o projeto da arquitetura de informação de um website envolve diversas dificuldades para o design dos quatro sistemas que compões a arquitetura de informação. A superação dessas dificuldades torna o projeto de arquitetura de informação um problema complexo, requerendo uma metodologia para organizar o trabalho do arquiteto e garantir a qualidade do seu produto final.

Se o processo para gerenciar o design de ambientes de informação não for explícito, as chances de falhas aumentam. Portanto, o gerenciamento do design de ambientes de informação é mais eficiente e efetivo quando segue um método. (MORROGH, 2003, pág. 117)

Metodologia ${ }^{14}$ é um conjunto de técnicas, métodos e padrões amparados por um corpo teórico destinado a resolução de uma classe de problemas. Ela nasce da "reflexão de um campo do conhecimento sobre si mesmo, enquanto prática teórica" (IMMACOLATA, 2003, pág. 90), como vem ocorrendo com o campo da Arquitetura da Informação.

\footnotetext{
14 O termo "metodologia" possui uma ambigüidade natural no sentido da palavra e por isso precisa ser conceituado. Segundo IMMACOLATA (2003, pág. 93) “ocorre com a palavra 'metodologia' o mesmo que ocorre com as palavras 'comunicação', 'história', 'economia' e outras, que são empregadas tanto para indicar uma disciplina quanto o seu objeto de estudo". Nesse trabalho a palavra "metodologia" é utilizada para indicar o objeto de estudo, ou seja, o conjunto das técnicas, métodos e padrões.
} 
As primeiras discussões sobre uma metodologia para projetos de arquitetura de informação de websites surgiram junto com a formulação desse campo no trabalho pioneiro de ROSENFELD e MORVILLE. A primeira edição do "urso polar" 15 , publicada em 1998, já continha os passos iniciais para formar essa metodologia. A segunda e a terceira edição desse livro a aperfeiçoaram e o tornaram a referência mais citada na literatura.

Diversos outros autores (SAPIENT apud MORROGH, 2003; BUSTAMANTE, 2004; WODTKE, 2003; DIJCK, 2003; REISS, 2000; SHIVA, 2000, WEST, 2001) propuseram novas visões e incrementos para a metodologia de projetos de arquitetura de informação, trazendo ferramental técnico e teórico de diversas disciplinas como a Ciência da Informação, a Interação Humano-Computador e todas as demais que compõem o seu caráter multi-disciplinar apresentado no capítulo 3.

Porém ainda não existe uma consolidação e comprovação de todas suas técnicas de modo a formar um corpo teórico que caracterize a disciplina, o que faz do processo de design de arquitetura de informação algo ainda bastante intuitivo (HAVERTY, 2002).

\subsection{Princípios para metodologias de projeto de arquitetura de informação de websites}

Antes de iniciar uma análise das metodologias de projetos de arquitetura de informação de websites é preciso levantar quais princípios regem essas metodologias de modo a formar um quadro de referência para avaliar as metodologias propostas.

Uma característica marcante nos projetos de arquitetura de informação de websites é o fato de serem processos de design (MORROGH, 2003). Essa característica, aponta HAVERTY (2002), fica evidente no fato de que o trabalho de um arquiteto de informação é um processo de criar soluções para problemas de design. BELTON (2003) corrobora com esse conceito ao comparar a Arquitetura de Informação com a Arquitetura e propõe a

\footnotetext{
15 Apelido do livro Information Architecture for the Word Wide Web de ROSENFELD. \& MORVILLE publicado pela O'Reilly em 1998. A capa do livro tem uma foto desse animal.
} 
adoção de uma abordagem de design na formação dos arquitetos de informação. Por fim a definição de Arquitetura de Informação proposta pelo Information Architecture Institute (2005) e por ROSENFELD e MORVILLE (2002) vistas no capítulo 3 também explicitam essa característica.

Segundo CHIOU (2003) processos de design são processos criativos e de grande esforço intelectual nos quais se faz um balanceamento entre forma e função para criar um objeto útil e agradável aos usuários. FRIEDMAN (2003) concorda com essa definição ao afirmar que design é um processo orientado ao objetivo de resolver problemas, atender necessidades ou criar algo novo e útil. SIMON (apud FRIEDMAN, 2003, pág. 508) também corrobora e cita que "o design é um processo de conduzir ações com o objetivo de transformar situações existentes em situações preferidas". Projetos de arquitetura de informação possuem as características dos processos de design e por isso os conceitos desses processos podem ser aplicados nos projetos de arquitetura de informação.

De fato, o próprio projeto do website como um todo também é um processo de design e cada uma das fases que o compõem também são. Como em um fractal, onde o desenho das partes é igual ao desenho do todo, tanto a visão macro do projeto do website quanto a visão micro de cada uma das suas fases são processos de design.

Segundo MORROGH (2003) um processo de design possui basicamente quatro fases:

- Análise: onde os usuários e o ambiente de uso do objeto são estudados e os objetivos são definidos.

- Design Conceitual: onde as estratégias e as regras da solução são definidas.

- Design e Desenvolvimento: onde as estratégias e regras são aplicadas especificando, com suficiente riqueza, os detalhes do objeto a ser construído.

- Implementação: onde o objeto é construído conforme a especificação. 
NEWTON (apud BELTON, 2003) propõe outra divisão ao processo de design, adotada na Harvard School of Design nos anos de 1950 e 1960, e que também expressa a visão de FRIEDMAN (2000). Segundo NEWTON (apud BELTON, 2003, pág. 145) o processo de design possui três fases:

- Programação: a fase para reconhecer e delimitar o problema básico em termos de necessidades humanas, e para decidir de forma geral que conjunto de ações ou provisões são mais apropriados para produzir a solução.

- Análise: na qual o designer analisa cuidadosamente as relações entre as várias atividades envolvidas no problema e, por meio de sínteses visuais $e$ imaginativas, desenvolve a estrutura específica - a forma e a organização específica - da solução física concreta que irá acomodar o complexo de atividades.

- Representação e Implementação: para que a criação da sua imaginação possa realmente existir, o designer prepara desenhos de trabalhos e outros documentos de contratação e fornece supervisão e todas as diretivas para os homens cujos esforços combinados resultarão na construção do produto final, na obra do design.

Pode-se observar que, apesar das diferenças de nomenclatura, existe muita semelhança entre as fases dos processos de design propostos por MORROGH (2003) e NEWTON (apud BELTON, 2003) e até com as fases da metodologia de projeto de websites proposta por MEMÓRIA (2006), MELLY (2003) e ALMEIDA e OLIVEIRA (2002) vistas anteriormente.

Em todos esses casos o processo de design inicia com uma fase na qual o projetista levanta e analisa as informações sobre os usuários, suas necessidades e o seu ambiente para definir o escopo e os requisitos do projeto. MORROGH (2003) denomina essa fase de "Análise", NEWTON (apud BELTON, 2003) a denomina de "Programação", ALMEIDA e OLIVEIRA (2002) a denomina de "Entender" e tanto MEMÓRIA (2006) quanto MELLY (2003) a denominam de "Compreensão". Nenhum desses termos adotados 
evidencia a principal ação executada nessa fase, que é pesquisar todas as informações necessárias para compreender e delimitar o problema a ser resolvido. Assim utilizaremos o termo Pesquisa para definir essa fase evidenciando essa ação.

No caso específico das metodologias de projetos de arquitetura de informação, as abordagens de Design Centrado no Usuário da Ciência da Informação trazem uma importante contribuição para a fase de Pesquisa porque possuem fundamentos teóricometodológicos e técnicas que podem ser empregadas nessa fase. Essas abordagens propõem formar uma visão holística do usuário e buscam uma compreensão global das suas situações de uso da informação antes, durante e depois das suas interações com o sistema de informação (no caso o website). Essa proposta se alinha com o trio usuárioconteúdo-contexto que, segundo ROSENFELD e MORVILLE (2006), a Arquitetura de Informação busca compreender e atender.

Após a fase de Pesquisa, o processo de design possui uma fase eminentemente criativa, na qual se concebe a visão macro, as linhas gerais, da solução. MORROGH (2003) chama essa fase de "Design Conceitual", NEWTON (apud BELTON, 2003) a chama de "Análise" e ALMEIDA e OLIVEIRA (2002) a chamam de "Planejar". MELLY (2003) e MEMÓRIA (2006) utilizam o termo "Concepção". Este último é o mais adequado porque representa melhor a principal ação dessa fase: conceber a solução do problema de design por meio da inventividade do projetista.

É na fase de Concepção que se tem a maior contribuição da abordagem de Design Centrado no Usuário da Interação Humano-Computador na metodologia de projeto de arquitetura de informação. Essa abordagem possui três fundamentos: focalizar no usuário e nas suas tarefas desde o inicio do projeto, aplicar medidas empíricas da usabilidade e utilizar um processo de design iterativo e interativo com refinamentos sucessivos. Esses fundamentos e as técnicas deles decorrentes, especialmente as avaliações de usabilidade, são ferramentas importantes para que o arquiteto de informação possa definir, validar e refinar sua solução.

Após a fase de Concepção, o processo de design apresenta uma fase na qual a visão macro da solução é detalhada em documentos e diagramas que explicam como construir o objeto, que no caso dos projetos de arquitetura de informação é o próprio 
website. NEWTON (apud BELTON, 2003) denomina essa fase de "Representação", MORROGH (2003) a chama de "Design e Desenvolvimento", ALMEIDA e OLIVEIRA (2002) a chamam de "Executar" e tanto MELLY (2003) e quanto MEMÓRIA (2006) utilizam o termo "Construção". Como a principal ação nessa fase é especificar a construção do objeto, utilizamos o termo Especificação para denominá-la.

Por fim, o processo de design termina com uma fase na qual o objeto especificado é construído e disponibilizado para uso. ALMEIDA e OLIVEIRA (2002), MELLY (2003) e MEMÓRIA (2006) denominam essa fase o mesmo termo da fase anterior porque esses autores não a distinguem. MORROGH (2003) e NEWTON (apud BELTON, 2003) distinguem essa fase da anterior e ambos utilizam o termo "Implementação" para denominá-la. Distinguir as fases de Especificação e Implementação é importante nos projetos de arquitetura de informação porque a construção do website normalmente não é responsabilidade do arquiteto de informação e sim dos programadores e dos outros membros do time do projeto. Utilizamos o termo Implementação para denominar a última fase do processo de design porque é o que melhor representa a principal ação nessa fase: construir o objeto conforme a especificação.

Um aspecto que merece destaque nos processos de design é que normalmente eles não possuem uma fase de avaliação dos resultados destinada a analisar o produto final, o objeto que foi construído. ALMEIDA e OLIVEIRA (2002) são os únicos autores que possuem uma fase com esse objetivo na metodologia que propõem: a fase "Monitorar". Segundo FRIEDMAN (2003, pág. 514) “os designers freqüentemente terminam seu envolvimento com o projeto antes que as falhas apareçam e os contratantes normalmente não retornam ao designer original para reparar o trabalho".

Após a implementação, o objeto resultante do processo de design está construído e inicia-se seu uso. Nesse momento todas as estratégias e conceitos da solução definidos durante o projeto e que produziram o objeto de design são colocados a prova e os erros e acertos evidenciam-se. Assim, para buscar a melhoria da prática, a metodologia de projetos de arquitetura de informação precisa preocupar-se em avaliar os resultados dos projetos e registrar seus acertos e erros. Esses registros irão, ao longo do tempo, se 
consolidar em boas práticas e recomendações de design. É o acúmulo desse conhecimento que transformará a arte em ciência e o artesão em profissional.

A avaliação de resultados é também uma prática recomendada para qualquer metodologia de projetos como forma de aperfeiçoamento constante da qualidade e da técnica (PROJECT MANAGEMENT INSTITUTE, 2004) e, por isso, precisa estar presente nas metodologias de projetos de arquitetura de informação. Para FRIEDMAN (2003, pág. 521) é "a nossa interpretação e entendimento da experiência que conduz ao conhecimento".

Assim, as metodologias de projetos de arquitetura de informação necessitam ter uma fase que complemente o processo de design e avalie os resultados do projeto. Utilizamos o termo "Avaliação" para denominar essa fase de forma a evidenciar sua principal ação.

Sintetizando os conceitos apresentados, temos os seguintes princípios que formam o quadro de referência para análise das metodologias de projeto de arquitetura de informação de websites:

- Possuir cinco fases distintas:

- Pesquisa: na qual são pesquisadas e analisadas as informações sobre os usuários, suas necessidades e o seu ambiente para definir o escopo e os requisitos do projeto.

○ Concepção: uma fase eminentemente criativa, na qual se concebe a visão macro da solução.

○ Especificação: na qual a visão macro da solução é detalhada em documentos e diagramas que explicam como construir o website.

○ Implementação: na qual o website é construído conforme especificado e disponibilizado para uso.

○ Avaliação: na qual o resultado do projeto é avaliado em função dos seus objetivos iniciais para se registrar os acertos e erros.

- Aplicar na fase de Pesquisa os fundamentos e técnicas das abordagens de Design Centrado no Usuário da Ciência da Informação de forma a buscar 
uma visão holística do usuário e uma compreensão global de suas situações particulares de uso de informação, incluindo o antes e o depois de suas interações com o website.

- Aplicar na fase de Concepção os fundamentos e técnicas do Design Centrado no Usuário da Interação Humano-Computador de forma a focalizar no usuário e nas suas tarefas desde o início do projeto a ter um processo de design com um ciclo iterativo e interativo de definição, validação e refinamento da solução utilizando avaliações de usabilidade.

\subsection{Análise das metodologias de projeto de arquitetura de informação de websites}

Por ser um campo novo, ainda existe uma carência de literatura sobre metodologias de projetos de arquitetura de informação de websites (BUSTAMANTE, 2004). Dentre as metodologias encontradas na revisão bibliográfica três merecem destaques pelo seu grau de detalhamento. Essas metodologias estão apresentadas na Figura 6 e são analisadas a seguir. 


\section{Figura 6 - Metodologias de projetos de arquitetura de informação de websites}

Metodologia de projeto de Arquitetura de Informação de websites de ROSENFELD e MORVILLE (2002)

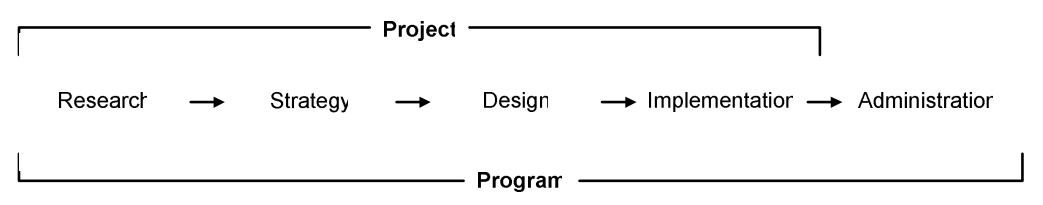

Metodologia de projeto de Arquitetura de Informação de websites de SAPIENT (apud MORROGH 2003)

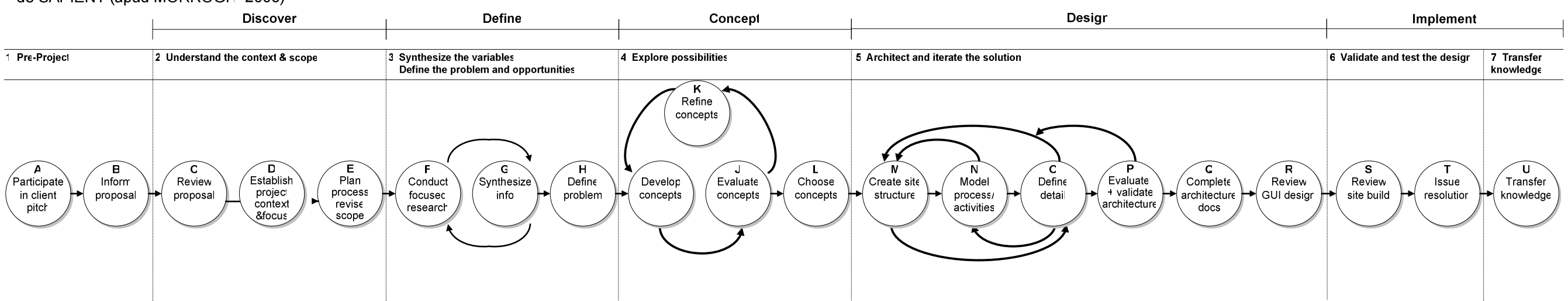

Metodologia de projeto de Arquitetura de Informação de websites de BUSTAMANTE (2004)
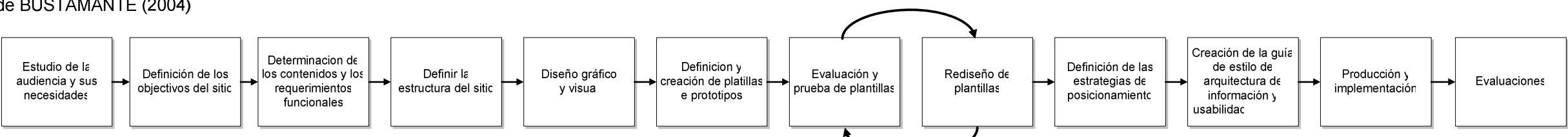

Desenho elaborado a partir da seqüência das fases descritas em BUSTAMANTE (2004) 
A primeira metodologia, proposta por ROSENFELD e MORVILLE (2002), é a mais completa e detalhada de todas. Esses autores, como já visto, são pioneiros no campo da Arquitetura de Informação e a metodologia que propõem tem suas origens e comprovação prática na pioneira Argus, a primeira empresa a trabalhar com Arquitetura de Informação de websites.

Essa metodologia está dividida em 5 fases: Pesquisa (Research), Estratégia (Strategy), Design, Implementação (Implementation) e Administração (Administration). Para esses autores, um projeto de arquitetura de informação termina após a execução das primeiras quatro fases. A quinta fase representa o gerenciamento do website e por isso se destaca do projeto. As cinco fases juntas compõem, na visão desses autores, um programa de Arquitetura de Informação, que tem o objetivo de definir, administrar e melhorar continuamente a organização da informação do website.

A segunda metodologia, proposta pela empresa SAPIENT (2000) e documentada por MORROGH (2003), possui um menor grau de detalhamento porque não descreve as técnicas utilizadas em cada fase. Essa metodologia nasceu no ano 2000 como resultado da fusão da metodologia da Sapient e de outras duas empresas desenvolvedoras de websites: a Studio Archetype e a Adjacency ${ }^{16}$ (SAPIENT, 2000).

A metodologia da SAPIENT (apud MORROGH, 2003) divide o projeto de arquitetura de informação em 5 fases subdivididas em 19 atividades. Essas 5 fases são: Descoberta (Discover), Definição (Define), Concepção (Concept), Design (Design) e Implementação (Implement). Nessa metodologia existe também uma etapa de Pré-Projeto que antecede todas as demais e tem o objetivo de explicar aos profissionais da empresa contratante (ou outra entidade que esteja contratando o projeto) o que é Arquitetura de Informação e elaborar uma proposta informal de trabalho.

Explicar aos profissionais da empresa contratante como é o trabalho do arquiteto de informação é uma forma interessante de divulgar esse novo campo, de despertar nesses

\footnotetext{
${ }^{16}$ A Sapient adquiriu inicialmente a Studio Archteype em agosto de 1998 e depois a Adjacency em abril de 1999 (SAPIENT, 2000).
} 
profissionais a importância da Arquitetura de Informação no design de websites e de conseguir que eles se comprometam com o projeto. ROSENFELD e MORVILLE (2002) também citam a importância dessa explicação e reservam uma atividade para isso dentro da fase de Pesquisa (Research) na metodologia que propõem.

Diferente da metodologia de ROSENFELD e MORVILLE (2002), na metodologia da SAPIENT (apud MORROGH, 2003) não existem uma fase destinada a administrar o website. O motivo para isso é que a SAPIENT é uma empresa focada apenas na criação de websites e não na sua operação no dia-a-dia.

Por fim a terceira metodologia é proposta por BUSTAMANTE (2004) e mostra um grau de detalhamento das fases e técnicas intermediário em relação às duas propostas anteriores. Porém esse autor não demonstra comprovação prática da efetividade da sua metodologia. Trata-se apenas de uma coleção das "melhores e mais elementares práticas que devem ser executadas para se obter um produto de sucesso e de qualidade" (BUSTAMANTE, 2004, pág. 38).

A metodologia de BUSTAMANTE (2004) é a que apresenta a maior quantidade de fases, 12 no total: Estudo da audiência e suas necessidades (Estudio de la audiência y sus necessidades), Definição dos objetivos do website (Definición de los objetivos del sitio), Determinação dos conteúdos e requerimentos funcionais (Determinación de los contenidos y los requerimientos funcionalies), Definição da estrutura do website (Definir la estructura del sítio), Desenho gráfico e visual (Diseño gráfico e visual), Definição e criação de planos e protótipos (Definición y creación de plantillas y prototipos), Avaliação e prova dos planos (Evalución y prueba de plantillas), Redesenho dos planos (Rediseño de plantillas), Definiçãa das estratégias de posicionamento (Definición de las estrategias de posicionamiento), Criação do guia de estilo da arquitetura de informação e usabilidade (Criación de la guía de estilo de arquitectura de información y usabilidad), Produção e Implementação (Producción e implementación), e Avaliações (Evaluaciones).

Merece destaque nessa metodologia a presença de uma etapa de Definição das estratégias de posicionamento do website (Definición de las estrategias de 
posicionamiento). Na proposta de BUSTAMANTE (2004), um website também é visto como um produto ${ }^{17}$ que se lança no mercado e por isso precisa ter definidas suas estratégias mercadológicas, como a publicidade e a promoção. Essa etapa tem a mesma função da modelagem conceitual na metodologia de projeto de websites proposta por MELLY (2003) e vista na Figura 5.

As metodologias propostas por ROSENFELD e MORVILLE (2002) e SAPIENT (apud MORROGH, 2003) não explicitam a necessidade de definir as estratégias mercadológicas do website no projeto de arquitetura de informação porque esses autores consideram que essa tarefa é atribuição dos gerentes e diretores da empresa contratante em parceria com suas áreas de marketing. Para esses autores, cabe ao arquiteto de informação compreender esse planejamento e utilizá-lo como um dos requisitos de projeto.

Outros autores (SHIPLE, 2001; DIJCK, 2003; WODTKE, 2003; WEST, 2001; REISS, 2000) também propõem guias ou tutoriais para a execução de projetos de arquitetura de informação de websites. Porém, apesar desses autores trazerem contribuições importantes e que serão citadas no decorrer desse trabalho, eles não apresentam uma metodologia completa e detalhada como as propostas de ROSENFELD e MORVILLE (2002), SAPIENT (apud MORROGH, 2003) e BUSTAMANTE (2004). As propostas desses autores limitam-se a descrever as três primeiras fases do processo de design: Pesquisa, Concepção e Especificação.

Embora todas as metodologias, guias e tutoriais encontrados na literatura apresentem várias diferenças, especialmente nas nomenclaturas e nos graus de detalhamento das etapas, métodos e técnicas, é possível identificar muitas semelhanças entre elas quando analisadas segundo o quadro de referência proposto no início desse capítulo. Na Figura 7 estão apresentadas as três metodologias vistas anteriormente analisadas segundo as cinco fases do quadro de referência. Em seguida cada uma dessas fases será analisada nas as três metodologias.

\footnotetext{
${ }^{17}$ O conceito de produto utilizado por BUSTAMANTE (2004) é o mesmo definido no capítulo Capítulo 2 .
} 
Figura 7 - Análise das metodologias nas fases do quadro de referência

Metodologia de projeto de Arquitetura de Informação de websites de ROSENFELD e MORVILLE (2002)

\begin{tabular}{ll}
\multicolumn{2}{c}{ Legenda } \\
P Fase de Pesquise & Fase de Implementaçãa \\
C Fase de Concepçãa & A Fase de Avaliação \\
E Fase de Especificaçãa & $\begin{array}{l}\text { Não identificado em } \\
\text { nenhuma fase }\end{array}$
\end{tabular}

\begin{tabular}{|c|c|c|c|c|c|c|}
\hline $\begin{array}{l}\text { Researct } \\
\quad \text { P }\end{array}$ & $\rightarrow$ & $\begin{array}{l}\text { Strategy } \\
\text { C }\end{array}$ & $\rightarrow$ & $\begin{array}{c}\text { Desig } \\
\text { E }\end{array}$ & $\rightarrow$ Implementatior $\rightarrow$ & $\begin{array}{c}\text { Administratior } \\
\text { A }\end{array}$ \\
\hline
\end{tabular}

Metodologia de projeto de Arquitetura de Informação de websites de SAPIENT (apud MORROGH 2003)

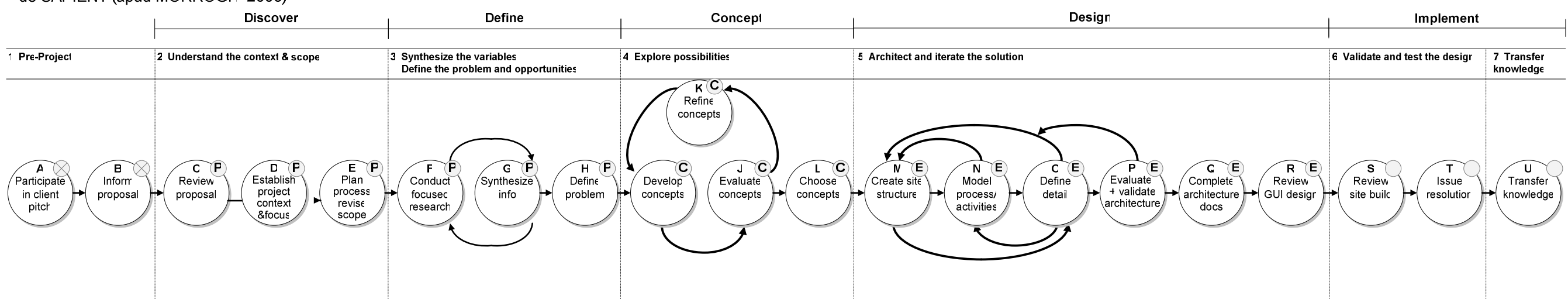

Metodologia de projeto de Arquitetura de Informação de websites de BUSTAMANTE (2004)

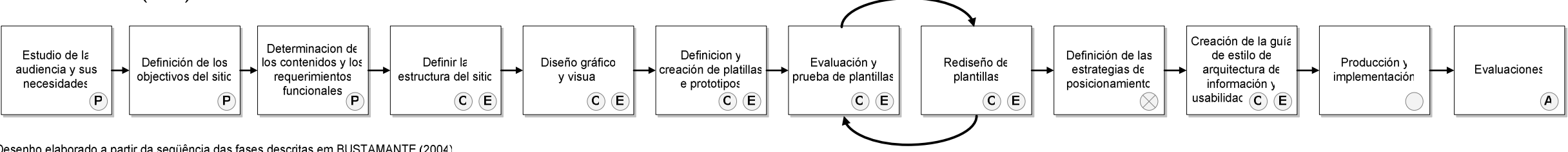

Desenho elaborado a partir da seqüência das fases descritas em BUSTAMANTE (2004) 


\subsubsection{A fase de Pesquisa}

A fase de Pesquisa é o momento no processo de design no qual os usuários, as necessidades e o ambiente são estudados para se delimitar o problema a ser resolvido. Nas três metodologias propostas podem ser observadas etapas e atividades com esse objetivo, como visto na Figura 7.

Na metodologia proposta por ROSENFELD e MORVILLE (2002), todo o trabalho da fase de Pesquisa está concentrado numa fase que leva o mesmo nome (Pesquisa ou Research). Para esses autores a etapa de Pesquisa inicia o projeto de arquitetura de informação e tem por objetivo entender completa e detalhadamente o problema a ser resolvido e definir o escopo e as restrições do projeto. É o momento em que o trio usuárioconteúdo-contexto é cuidadosamente estudado para se determinar todas as restrições que o website precisa atender. A função dessa etapa é “obter um entendimento de alto nível dos objetivos e do contexto de negócio, da arquitetura de informação existente, do conteúdo e da audiência futura" (ROSENFELD e MORVILLE, 2002, pág. 212).

Na metodologia proposta pela SAPIENT (apud MORROGH, 2003) existem duas fases destinadas a executar a fase de Pesquisa: Descoberta (Discover) e Definição (Define). A fase de Descoberta tem por objetivo entender o contexto e o escopo do projeto. Trata-se de uma fase de planejamento, na qual é feita a transferência de conhecimento da empresa para o arquiteto e se planeja a pesquisa que será executada na etapa seguinte.

O foco da fase de Definição é pesquisar e sintetizar as variáveis do projeto e definir o problema e as oportunidades. Para isso são conduzidas pesquisas com o intuito de entender o negócio da empresa, os usuários, suas necessidades, seus comportamentos e as tecnologias que poderão ser utilizadas no website.

Por fim, na metodologia proposta por BUSTAMANTE (2004) temos a fase de Pesquisa dividida em três fases: Estudo da audiência e suas necessidades (Estudio de la audiência y sus necessidades), Definição dos objetivos do website (Definición de los objetivos del sitio), Determinação dos conteúdos e requerimentos funcionais 
(Determinación de los contenidos y los requerimientos funcionalies). As duas primeiras etapas têm o objetivo de pesquisar respectivamente o usuário e a empresa. A última etapa tem a função de avaliar os resultados das pesquisas realizadas nas duas fases anteriores para sintetizar o escopo e os requisitos do projeto com relação aos conteúdos e funcionalidades que deverão ser disponibilizados no website.

Outros autores (REISS, 2000; SHIPLE, 2001; DIJCK, 2003; WODTKE, 2003) também evidenciam a importância da fase de Pesquisa e ressaltam os mesmos objetivos: pesquisar o usuário e a empresa para definir os requisitos e restrições do website a ser construído.

\subsubsection{Variáveis de pesquisa}

Observando-se as etapas e atividades nas metodologias de ROSENFELD e MORVILLE (2002), SAPIENT (apud MORROGH, 2003) e BUSTAMANTE (2004) nota-se que todas elas pesquisam dois grandes grupos de variáveis. $\mathrm{O}$ primeiro grupo são as variáveis sobre a empresa, que identificam seus objetivos e capacidades. O segundo grupo são as variáveis sobre os usuários, que identificam como eles se segmentam, quais são as suas necessidades, os seus comportamentos e as suas linguagens. Esses dois grupos de variáveis também estão presentes nos trabalhos de REISS (2000), SHIPLE (2001), DIJCK (2003) e WODTKE (2003).

A existência desses dois grupos de variáveis se justifica porque, conforme os conceitos de necessidade apresentados no capítulo 2, um website é um produto desenvolvido por uma empresa para atender as necessidades de seus clientes/usuários. Em troca, como afirma REISS (2000), a empresa espera ser recompensada de forma tangível (aumento de vendas, redução de custos, melhora na produtividade, etc.) ou intangível (divulgação da marca, melhoria da imagem, etc.). Assim, esses dois grupos de variáveis visam mapear a relação usuário-empresa que o website deverá atender. Esses dois grupos estão detalhados a seguir: 


\subsection{Grupo de variáveis de pesquisa sobre a empresa}

As variáveis sobre a empresa formam o primeiro grupo de variáveis estudadas na fase de Pesquisa e retratam os objetivos de negócio da empresa, as suas restrições e capacidades, a sua organização e os seus processos internos. DIJCK (2003) cita que essas variáveis têm influência direta nas decisões de design e por isso o arquiteto de informação precisa estar familiarizado com elas.

A síntese do trabalho dos diversos autores (REISS, 2000; SHIPLE, 2001; ROSENFELD e MORVILLE, 2002; DIJCK, 2003; WODTKE, 2003; SAPIENT apud MORROGH, 2003; BUSTAMANTE, 2004) explicita quatro variáveis que compõem o grupo de variáveis sobre a empresa. São elas:

\section{- Proposta de valor ou Objetivo do negócio}

Retrata a função principal, o propósito, a razão da existência do website e determina a direção que o projeto deverá seguir e os resultados esperados.

Por ser fruto do planejamento estratégico, a explicitação da proposta de valor do website é altamente dependente do grau de maturidade da empresa nessa área. Empresas com baixo grau de maturidade não têm seus objetivos, restrições e públicos-alvos bem definidos, o que dificulta o trabalho de pesquisa dessas informações.

Quando você insiste em falar sobre estratégia, os membros do time vão frequentemente resistir, dizendo que eles "apenas querem fazer as coisas". Não desista - ter a estratégia discutida no início vai poupar tempo depois quando se discutir as funcionalidades e detalhes do design. (DIJCK, 2003, pág. 24)

Cabe muitas vezes ao arquiteto de informações estimular a empresa a definir a proposta de valor do website. BUSTAMANTE (2004) reserva na sua metodologia uma fase exclusivamente para isso (etapa Definição dos objetivos do website ou Definición de los objetivos del sitio), na qual são aplicadas técnicas próprias da elaboração de um planejamento estratégico. 
A crítica a essa proposta de BUSTAMANTE vem do fato de que a elaboração de um planejamento estratégico envolve técnicas e habilidades que não são próprias da Arquitetura de Informação, o que pode produzir propostas de valor superficiais e mal definidas. Segundo SOUZA (2001), propostas de valor mal definidas levam o projeto de design de um website a resultados inesperados.

\section{- Público-Alvo}

No grupo de variáveis sobre a empresa, público-alvo é o grupo de pessoas que a empresa espera que utilize o website. Podem existir vários públicos-alvos diferentes, separados conforme seus objetivos, necessidades e comportamentos.

A determinação dos públicos-alvos do website é fundamental para garantir sua usabilidade. Como visto, a norma ISO 9241-11 aponta que a usabilidade trata de facilitar o uso de um produto para usuários específicos, não para qualquer usuário, porque criar um produto com uma boa usabilidade para qualquer usuário é impossível na prática.

\section{- Requisitos e Diretrizes de Implementação}

Os requisitos e diretrizes de implementação são as variáveis que mapeiam o contexto da empresa onde o website está inserido de forma a identificar a capacidade que essa empresa tem de implementá-lo e administrá-lo. A SAPIENT (apud MORROGH, 2003) e WODTKE (2003) demonstram preocupação em pesquisar essas variáveis e ROSENFELD e MORVILLE (2002) justificam a importância de pesquisá-las como forma de garantir que o projeto do website seja viável de implementação.

No nosso mundo dos sonhos, nós gostaríamos de projetar nossa arquitetura de informação independente da tecnologia, e um time de analistas de sistemas e desenvolvedores de software construiria a infra-estrutura e as ferramentas que suportariam nossa visão. 
No mundo real isso não ocorre com freqüência. Normalmente nós temos que trabalhar com as ferramentas e a infra-estrutura que já existe. Isso significa que nós precisamos avaliar o ambiente de IT [Information Technology ou Tecnologia da Informação] bem no começo do projeto para que nossas estratégias e o nosso design seja baseado na realidade. (ROSENFELD e MORVILLE, 2006, pág. 239)

Sintetizando os autores citados nota-se a existência de três variáveis que formam os requisitos e as diretrizes de implementação:

- Requisitos Técnicos: determinam as tecnologias que serão utilizadas para implementar o projeto e os sistemas computacionais com os quais o website deverá se integrar. Abrangem as linguagens de programação (HTML, Javascript, Flash, ASP, Java, etc.), especificações dos computadores dos usuários e dos servidores (sistema operacional, browser, resolução do monitor, etc.), ferramentas de desenvolvimento e operação do website (editores de HTML, banco de dados, softwares de gerenciamento de conteúdos, etc.) e os sistemas legados da empresa (ERP, CRM, etc.).

- Requisitos Operacionais: determinam os profissionais e máquinas que atuarão na operação do website após sua implantação. Abrangem todos os processos internos da empresa que surgirão ou se modificarão com o nascimento do website (resposta de e-mails, atendimento a clientes, manutenção e publicação dos conteúdos, entrega de pedidos, etc.).

- Diretrizes de Posicionamento: determinam como o website irá se comunicar com o usuário e que imagem deve-lhe transmitir. Abrange as diretrizes de comunicação da empresa e diretrizes de cores e uso de logotipos, tom de linguagem, etc.

\section{- Recompensa da empresa}

A recompensa da empresa é a variável que determina o lucro da empresa com o website, o retorno esperado. Trata-se da tradução da proposta de valor do website em indicadores numéricos ou qualitativos que irão mensurar o desempenho e avaliar o sucesso 
do website. Até mesmo empresas sem fins lucrativos ou organizações do terceiro setor (ONGs) esperam alguma recompensa quando lançam um website (captar mais doações, divulgar seus trabalhos, conquistar novos voluntários, etc.).

De forma genérica, esses indicadores versam sobre tempo (redução de prazo, aumento da agilidade, etc.), dinheiro (redução de custo, aumento da receita, etc.) e satisfação dos usuários (aumento da qualidade do serviço, diminuição de reclamações, etc.) (REISS, 2003).

REISS (2000) e SOUZA (2001) são os autores que demonstram maior preocupação em determinar esses indicadores. Para SOUZA (2001), esses indicadores precisam ser determinados no início do projeto e comunicado a toda equipe para que todos tenham clareza do objetivo que o website pretende alcançar.

REISS (2000) também cita a importância de determinar esses indicadores no início do projeto, especialmente nos casos onde o website tem por objetivo melhorar uma situação existente. Nesses casos os indicadores precisam ser mensurados antes e depois do projeto para avaliar se a mudança gerou melhorias.

\subsection{Grupo de variáveis de pesquisa sobre o usuário}

O segundo grupo de variáveis a serem estudadas na fase de Pesquisa são as variáveis de pesquisa sobre o usuário, as quais tem a função de explicar quem é o usuário do website, quais são suas necessidades, o seu comportamento e a sua linguagem. Trazer o usuário para o centro das decisões do projeto é a proposta das abordagens de Design Centrado no Usuário, sejam as da Ciência da Informação, sejam as da Interação HumanoComputador. Daí a importância de pesquisar esse grupo de variáveis.

A informação obtida sobre os usuários no grupo de variáveis sobre a empresa (público-alvo do website) acumula a experiência de relacionamento da empresa com seus clientes e, por isso, merece ser respeitada. Porém essas variáveis podem ser influenciadas pela cultura, paradigmas e políticas internas da empresa, o que pode dificultar o projeto do sistema de organização e rotulação, como visto no capítulo anterior. Dessa forma, o grupo 
de variáveis sobre o usuário tem o objetivo secundário de comprovar a veracidade do grupo de variáveis da empresa.

Outro fator que motiva a pesquisa do grupo de variáveis sobre o usuário é o fato de que as informações que o arquiteto de informação precisa para o seu trabalho normalmente não existem dentro da empresa (WODTKE, 2003).

Todos os autores levantados na literatura (REISS, 2000; SHIPLE, 2001; ROSENFELD e MORVILLE, 2002; DIJCK, 2003; WODTKE, 2003; SAPIENT apud MORROGH, 2003; BUSTAMANTE, 2004) demonstram preocupação em pesquisar o usuário e cada um deles apresenta uma lista própria de variáveis de pesquisa, que estão sintetizadas a seguir:

\section{- Objetivos do usuário}

Identifica as principais necessidades dos usuários que o website deverá atender. A análise do objetivo do usuário está diretamente relacionada com a proposta de valor do website, determinada no grupo de variáveis da empresa. Porém, como cita REISS (2000) e SOUZA (2001), nem sempre essas variáveis estão alinhadas. A proposta de valor que a empresa determina para o website pode não ser do interesse do usuário, daí a importância de pesquisar essa variável.

Como um website pode ter mais de um público-alvo, é possível que existam vários objetivos, provenientes de usuários distintos, que podem até serem conflitantes (WODTKE, 2003). Assim pode ser necessário priorizar os usuários e seus objetivos.

\section{- Experiência do usuário}

Mapeia o caminho (tarefas e objetivos) que o usuário percorre para atender suas necessidades e alcançar seus objetivos. A função dessa variável é mapear toda a experiência do usuário na busca da realização do seu objetivo e mapear o ambiente em que está inserido (REISS, 2000). 
O mapeamento desse caminho influencia diretamente o design do sistema de navegação porque aponta o caminho cognitivo com que o usuário está mais acostumado. Ele retrata todas as etapas, todos os passos que o usuário percorre para alcançar seu objetivo.

\section{- Informações necessárias em cada etapa}

Discrimina as informações que o usuário utiliza em cada passo no caminho que percorre para alcançar seu objetivo. Essas informações irão compor o espaço informacional do website.

\section{- Linguagem do usuário}

Indica os termos, os rótulos, que o usuário atribui as informações. Durante a execução do seu processo de busca de informação, o usuário utiliza uma linguagem própria na qual conceitos e símbolos se relacionam. A compreensão dessa linguagem irá auxiliar a definir o sistema de rotulação

\subsubsection{Técnicas empregadas na fase de Pesquisa}

As técnicas sugeridas pelos autores (REISS, 2000; SHIPLE, 2001; ROSENFELD e MORVILLE, 2002; DIJCK, 2003; WODTKE, 2003; SAPIENT apud MORROGH, 2003) para a fase de Pesquisa são basicamente técnicas para pesquisar as informações que delimitam os grupos de variáveis sobre a empresa e sobre o usuário. Essas técnicas estão apresentadas a seguir.

\subsection{Técnicas para pesquisa do grupo de variáveis sobre a empresa}

Para a pesquisa do grupo de variáveis sobre a empresa, os autores (REISS, 2000; SHIPLE, 2001; ROSENFELD e MORVILLE, 2002; DIJCK, 2003; WODTKE, 2003; SAPIENT apud MORROGH, 2003) sugerem a realização de entrevistas com os funcionários da empresa envolvidos com o projeto do website e a análise dos seus relatórios internos. 
Segundo ROSENFELD e MORVILLE (2002), é responsabilidade dos gerentes e diretores da empresa definir a proposta de valor do website, seus públicos-alvos e a recompensa da empresa porque essas variáveis são decorrentes do planejamento estratégico que esses profissionais elaboram para a empresa. A forma que esses autores sugerem para iniciar os trabalhos de pesquisa das variáveis sobre a empresa é entrevistar esses profissionais porque, além de serem a principal fonte dessas informações, envolvelos no início ajuda a garantir o comprometimento deles ao longo do projeto. Esse comprometimento é importante porque, como visto no capítulo anterior, o design do sistema de organização envolve dificuldades relacionadas às políticas internas da empresa e são esses profissionais que têm poder e condições de resolvê-las.

WODTKE (2003) sugere também a consulta à área de marketing para obter informações mais detalhadas sobre os públicos-alvos porque essa área tradicionalmente conduz pesquisas sobre esses públicos. Relatórios internos da empresa, como os relatórios de vendas, dúvidas, reclamações, etc., complementam e detalham os públicos-alvos porque trazem muita informação sobre seus hábitos, interesses e necessidades. Porém, como afirma essa autora, as informações obtidas com a área de marketing não são suficientes para um projeto de arquitetura de informação porque elas normalmente retratam os motivos que levam os vários públicos-alvos a comprar os produtos da empresa e não como eles organizam as informações e quais linguagens utilizam.

Por fim ROSENFELD e MORVILLE (2002) sugerem como fonte de informação para pesquisar essas variáveis entrevistas com os profissionais da empresa que atuam nas áreas de informática, marketing e de todas as demais áreas relacionadas com o website (SAC, vendas, assistência técnica, etc.) porque os profissionais dessas áreas conhecem os detalhes da operação da empresa e os seus sistemas legados.

\subsection{Técnicas para pesquisa do grupo de variáveis sobre o usuário}

Para a pesquisa das variáveis sobre o usuário, os autores (REISS, 2000; SHIPLE, 2001; ROSENFELD e MORVILLE, 2002; DIJCK, 2003; WODTKE, 2003; SAPIENT apud MORROGH, 2003) sugerem a realização do inventário de conteúdo, a análise das estatísticas de acesso ao website, a análise do log do mecanismo de busca e a realização de avaliações de usabilidade. 
O inventário de conteúdo (content inventory) é uma técnica que consiste em obter amostras dos conteúdos que serão disponibilizados no website e descrevê-los com metadados. Trata-se de um método que mistura variáveis dos grupos da empresa e do usuário e visa mapear e compreender todo o conjunto de informações que o arquiteto precisa organizar (ROSENFELD e MORVILLE, 2002; WODTKE, 2003).

Para tanto nessa técnica é feita uma análise bottom-up (de baixo para cima) empregando o "método da Arca de Noé": coletar duas amostras de cada tipo de conteúdo representativo. Como o objetivo da coleta é conhecer as propriedades dos conteúdos do website, a coleta termina quando o arquiteto perceber que não está mais descobrindo novidades e se sente capaz de inferir as propriedades de todos os demais conteúdos que irá organizar (MORVILLE, 2002; FRASER, 2001).

A visão bottom-up do inventário de conteúdo coloca essa técnica mais próxima do grupo de variáveis sobre a empresa porque se baseia mais nas informações que a empresa dispõe do que nas requeridas pelos usuários.

Uma sugestão para complementar o inventário de conteúdo e aproximá-lo do grupo de variáveis do usuário é acrescentar uma análise top-down (de cima para baixo), levantando quais informações o website precisa apresentar a partir do mapeamento das necessidades do usuário. Nem todos os passos do caminho que o usuário percorre para alcançar seus objetivos podem estar sendo atendidos pelos conteúdos obtidos na análise bottom-up. Assim a análise top-down irá trazer novos conteúdos para o website.

A análise top-down também pode ser aplicada aos conteúdos obtidos no inventário bottom-up, de forma a verificar quais conteúdos encontrados se relacionam com cada objetivo do usuário. Cada conteúdo disponibilizado em um website implica em custos para a empresa, tanto de implementação quanto de manutenção. Dessa forma espera-se com essa análise eliminar conteúdos "órfãos", conteúdos que não se relacionam a nenhum dos objetivos do usuário e consequentemente não trazem valor. 
A análise das estatísticas de acesso ao website consiste no uso de pacotes de software, como o Google Analytics ${ }^{18}$, que produzem estatísticas dos usuários (da onde vieram, quantos são novos, quantos são antigos, etc.) e das páginas exibidas (quantidade de exibição, dia e horário de maior visitação, etc.). Com a análise dessas estatísticas é possível identificar os conteúdos mais acessados no website auxiliando o design dos sistemas de organização e navegação (ROSENFELD e MORVILLE, 2006; REISS, 2000).

Pacotes de softwares mais sofisticados permitem analisar o caminho que o usuário percorreu ao longo do website (por quais página entrou, quais páginas visitou, em qual página abandonou o website). Essas ferramentas produzem informações bastante ricas sobre a navegação dos usuários, mas trazem mais informações sobre o uso do website do que sobre os próprios usuários. Elas não explicam porque o usuário entrou no website, se encontrou o que precisava e porque o abandonou. ROSENFELD e MORVILLE (2006) citam que algumas empresas utilizam questionários on-line apresentados no momento que o usuário abandona o website para obter essas informações.

A análise do log do mecanismo de busca é uma técnica sugerida por ROSENFELD e MORVILLE (2002) que consiste em levantar as palavras chaves digitadas pelos usuários ao utilizar o sistema de busca do website. Essa técnica permite revelar "problemas relativos à falta de consistência entre a organização da informações e sua expressão no sistema, por um lado, e a expectativa e interesse do usuário, por outro lado" (MELLY e colab. , 2003). Ela traz informações ricas sobre que conteúdos os usuários buscam, quais termos eles mais utilizam e como o website os supre, contribuindo diretamente para o design dos sistemas de organização e de rotulação.

Com relação as avaliações de usabilidade, os autores (REISS, 2000; SHIPLE, 2001; ROSENFELD \& MORVILLE, 2002; DIJCK, 2003; WODTKE, 2003; SAPIENT apud MORROGH, 2003) propõem técnicas que seguem a Discount Usability proposta por Nielsen (1994).

\footnotetext{
${ }^{18}$ O Google Analytics é um software gratuito desenvolvido pela Google e acessível pela web que permite mensurar quantas vezes uma página de um website foi visitada de onde vieram seus usuários. Disponível em http://www.google.com/analytics.
} 
As técnicas mais sugeridas são o Card Sorting e os testes com protótipos de baixa fidelidade como os protótipos em papel. Ambas se destinam a avaliar com o usuário propostas de soluções sobre quais informações o website deve conter e como serão organizadas. O Card Sorting apresenta essas hipóteses através de uma lista de conteúdos que solicita ao usuário classificar e rotular. Já os testes com protótipos de baixa fidelidade fazem isso por meio de telas prototipadas que simulam a navegação no website.

Essas técnicas são bastante eficientes e eficazes para se testar com usuários propostas de design de qualquer interface computacional. Porém não são adequadas para identificar as necessidades, os comportamentos e as informações que o usuário precisa por serem focadas na avaliação do uso da interface. Dessa forma, essas técnicas são mais adequadas nas fases seguintes do processo de design (Concepção e Especificação), na qual o modelo mental do website será definido e precisa ser avaliado.

A fase de Pesquisa na metodologia de projetos de arquitetura de informação precisa buscar técnicas voltadas a conhecer o usuário e as suas necessidades, ou seja, precisa de técnicas que sigam os paradigmas da abordagem alternativa dos estudos de usuários e necessidades da Ciência da Informação. BUSTAMANTE (2004) é o único autor que sugere técnicas baseadas nessa abordagem. Esse autor indica o uso da metodologia de identificação das necessidades de informação de usuários proposta por DEVANDASON e LINGAM (1996), que foi construída com base nessas abordagens. "Essa metodologia é recomendada pela sua simplicidade, clareza e facilidade de aplicação" (BUSTAMANTE, 2004, pág. 39).

\subsubsection{A fase de Concepção}

A fase de Concepção é o momento no processo de design onde são definidas as linhas gerais da solução. Trata-se da fase mais criativa do processo, na qual o produto final começa a ser concebido. Nas metodologias de projetos de arquitetura de informação é nessa fase que são definidas as regras dos sistemas de organização, de navegação, de rotulação e de busca. É o início da criação do modelo mental do website. 
Todas as três propostas de metodologias de projetos de arquitetura de informação (ROSENFELD e MORVILLE, 2002; SAPIENT apud MORROGH, 2003; BUSTAMANTE, 2004) demonstram grande preocupação com essa fase e dedicam atividades em suas metodologias exclusivamente para ela, como visto na Figura 7.

ROSENFELD e MORVILLE (2004, pág. 241) reservam na metodologia que propõem a fase Estratégia (Strategy) para a fase de Concepção do quadro de referência. Para esses autores, o objetivo da sua fase é produzir uma estratégia para a arquitetura de informação do website, ou seja, "uma armação conceitual de alto nível para estruturar e organizar um website ou intranet”. Essa estratégia cria as regras dos quatro sistemas que compõem a arquitetura de informação do website e tem por objetivo prover um firme senso de direção e escopo para prosseguir com confiança nas etapas seguintes da metodologia. Ela também facilita a discussão e o alinhamento entre os membros da equipe de projeto.

A SAPIENT (apud MORROGH, 2003) dedica à fase de Concepção uma fase com o mesmo nome (Concepção ou Concept). Nessa metodologia, as atividades que compõem a etapa de Concepção formam um ciclo interativo e iterativo de criação, avaliação e refinamento dos conceitos destinado a criar a visão geral do site. Esse ciclo segue a abordagem de Design Centrado no Usuário da Interação Humano-Computador.

O produto da fase de Concepção na metodologia da SAPIENT (apud MORROGH, 2003) é um documento que registra os conceitos criados, a visão macro do website. Na metodologia de ROSENFELD e MORVILLE (2002) também há uma atividade que produz um documento semelhante chamado Relatório Estratégico (Strategy Report). Esse documento tem a função de materializar os conceitos e regras dos quatro sistemas, alinhar a equipe de projeto e guiar as manutenções futuras do website.

A metodologia de BUSTAMANTE (2004) possui seis fases que formam a fase de Concepção: Definição da estrutura do website (Definir la estructura del sítio), Desenho gráfico e visual (Diseño gráfico e visual), Definição e criação de planos e protótipos (Definición y creación de plantillas y prototipos), Avaliação e prova dos planos (Evalución y prueba de plantillas), Redesenho dos planos (Rediseño de plantillas) e Criação do guia de estilo da arquitetura de informação e Usabilidade (Criación de la guía 
de estilo de arquitectura de información y usabilidad). As fases Avaliação e prova dos planos e Redesenho dos planos formam o ciclo interativo e iterativo, que também atende aos princípios do Design Centrado no Usuário da Interação Humano-Computador.

A fase Definição das estratégias de posicionamento (Definición de las estrategias de posicionamiento) não foi classificada em nenhuma fase do quadro de referência porque essa fase da metodologia de BUSTAMANTE (2004) tem por objetivo definir estratégias mercadológicas para o website, como visto anteriormente. A definição dessas estratégias não faz parte do escopo do trabalho do arquiteto de informação porque independem da organização do website.

Devido a existência da fase Desenho gráfico e visual, nota-se na metodologia de BUSTAMANTE (2004) uma mistura entre a Arquitetura de Informação e o Projeto Gráfico. Segundo esse autor, os elementos criados nessa etapa determinam o "look \& feel" do website e são de suma importância para o seu êxito. De fato é inegável a importância que o projeto gráfico tem no sucesso de um website e o quanto ele se inter-relaciona com a arquitetura de informação. Segundo NORMAN (2003) um design atrativo e agradável aumenta a usabilidade aparente da interface. Porém a estética não deve prevalecer sobre a compreensão da informação senão se terá um website bonito mas com baixa usabilidade.

BUSTAMANTE (2004) menciona também a importância de documentar os conceitos definidos na fase de Concepção e reserva uma das etapas da sua metodologia para isso, a etapa de Criação do Guia de Estilo de Arquitetura de Informação e Usabilidade (Criación de la guía de estilo de arquitectura de información y usabilidad). Para esse autor, a documentação dos conceitos é uma ferramenta de comunicação e alinhamento da equipe de projeto.

O ponto comum nessas metodologias propostas assim como no trabalho de outros autores (REISS, 2000; SHIPLE, 2001; DIJCK, 2003; WODTKE, 2003) é a presença do ciclo interativo e iterativo de criação, avaliação e refinamento dos conceitos na fase de Concepção.

Conforme a abordagem de Design Centrado no Usuário da Interação HumanoComputador, as atividades que compõem esse ciclo devem ser repetidas várias vezes no 
projeto e não existe uma regra de quando terminar de repeti-las. A SAPIENT (apud MORROGH, 2003) afirma que o ciclo termina quando a equipe de projeto avalia que a arquitetura proposta está boa o suficiente. HIX (apud MARTINEZ, 2000) aponta que três passagens por esse ciclo são suficientes para se obter uma versão satisfatória do design, sendo que a maior parte dos dados vem da primeira passagem. Disponibilidade de tempo e recursos influenciam diretamente na quantidade de passagens nesse ciclo (ROSENFELD e MORVILLE, 2002).

Assim, sintetizando todos esses autores citados temos que a fase de Concepção é responsável por definir os conceitos que formam a visão macro do website a ser criado. Para tanto essa fase inicia-se com um ciclo interativo e iterativo de três atividades: criação dos conceitos, avaliação dos conceitos e refinamento dos conceitos. Esse ciclo cria a visão geral e as regras dos quatro sistemas que compõem a arquitetura de informação do website (os sistemas de organização, de navegação, de rotulação e de busca). Depois de repetir essas atividades várias vezes de modo que a solução atenda o escopo e todos os requisitos do projeto, a fase de Concepção termina com uma atividade de documentação dos conceitos, que registra as regras dos quatro sistemas e as comunica à toda equipe do projeto. A Figura 8 ilustra essas quatro atividades que formam a fase de Concepção.

Figura 8 - Atividades que compõem a fase de Concepção

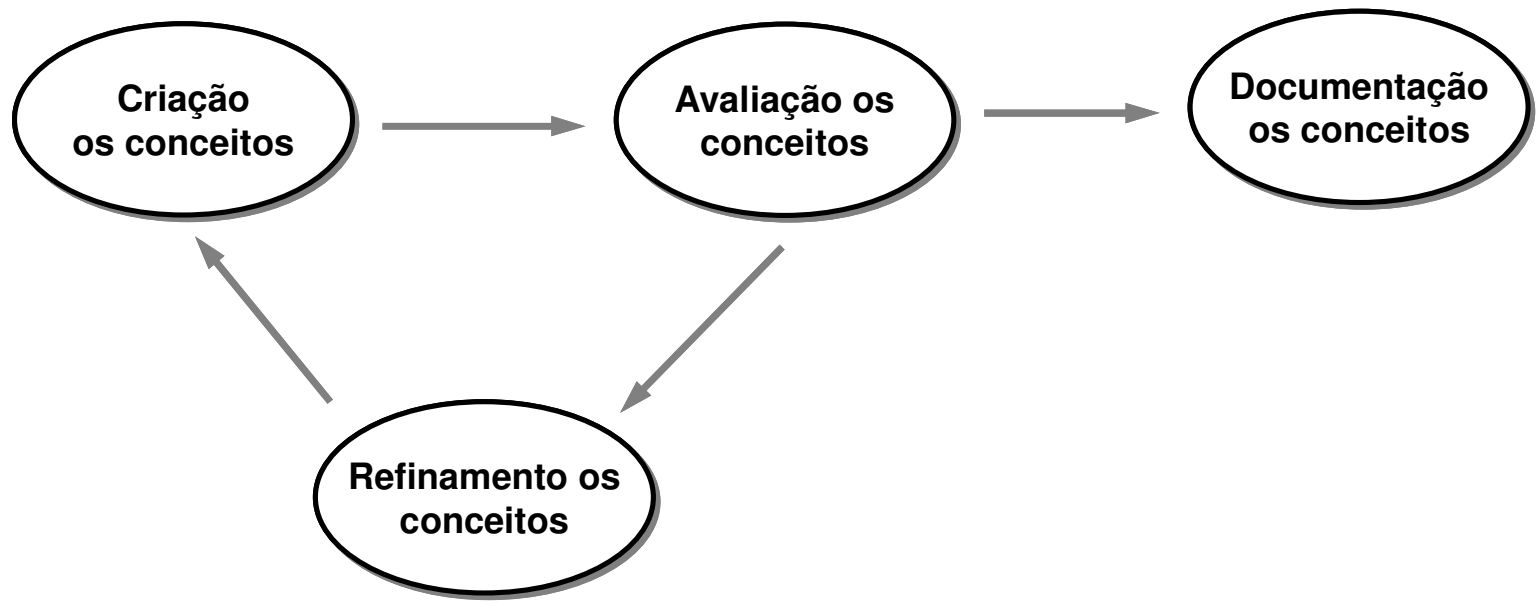


A seguir são apresentadas as principais técnicas sugeridas pelos autores citados para a fase de Concepção.

\subsubsection{Técnicas da fase de Concepção}

Todos os autores citados (ROSENFELD e MORVILLE, 2002; SAPIENT apud MORROGH, 2003; BUSTAMANTE, 2004; REISS, 2000; SHIPLE, 2001; DIJCK, 2003; WODTKE, 2003) apresentam técnicas apenas para as atividades de definição e avaliação dos conceitos na fase de Concepção. Não foram encontradas técnicas para o refinamento dos conceitos. Para a atividade de documentação dos conceitos foram encontrados apenas modelos da documentação a ser produzida, como o Relatório Estratégico (Strategic Report) proposto por ROSENFELD e MORVILLE (2002).

As técnicas sugeridas para as duas primeiras atividades dessa fase estão apresentadas a seguir.

\subsection{Técnicas para a definição dos conceitos}

A definição dos conceitos é uma atividade bastante criativa, na qual são concebidas as regras dos quatro sistemas que compõem a arquitetura de informação do website. Nela são exploradas todas as informações obtidas na fase de Pesquisa de modo a criar uma visão geral de um modelo de organização capaz de acomodar todos os requisitos do projeto.

As técnicas sugeridas para essa atividade são basicamente técnicas de estimulo à criatividade, geração de idéias em time e de comunicação das idéias. Elas têm a função de gerar sugestões e conceitos para compor as regras dos sistemas de organização, de navegação, de rotulação e de busca. ROSENFELD e MORVILLE (2002) são os autores que apresentam a lista mais completa de técnicas para essa atividade, que estão sintetizadas a seguir: 


\section{- Exploração de Metáforas}

Técnica sugerida por SHIPLE (2001), ROSENFELD e MORVILLE (2002) e BUSTAMANTE (2004) que consiste em fazer um mapeamento criativo de conceitos novos em conceitos familiares. "Metáforas são uma ferramenta poderosa para comunicar idéias complexas e gerar entusiasmo" (ROSENFELD e MORVILLE, 2002).

O uso de metáforas é recomendado por esses autores porque elas ajudam muito a entender e organizar as informações de um website em um nível alto de abstração. Porém as metáforas podem ser limitantes do processo criativo se seguidas a risca na implementação. Segundo NIELSEN (2000), é difícil encontrar uma única metáfora que consiga mapear exatamente todos os conteúdos e serviços que o website quer oferecer. Elas podem também dificultar o crescimento do website porque novos conteúdos que fazem sentido no contexto on-line podem não fazer sentido na metáfora e vice-versa.

\section{- Personas}

É a criação de arquétipos de usuários que servem de exemplos do público-alvo que irá utilizar o website. Trata-se da criação de um personagem com nome, foto e a descrição de suas habilidades, atitudes, restrições, experiências, comportamentos e objetivos (ROSENFELD e MORVILLE, 2002; WODTKE, 2003).

Essa técnica foi desenvolvida por COOPER (1999) e se baseia em técnicas de pesquisa de mercado. Sua função é materializar as abstrações sobre o público-alvo.

Personas ajuda você a entender para quem fazer o design e como agradar aquele usuário - aquele ser humano. Humanizar a audiência é o grande benefício dos personas. O “usuário" genérico se torna o ser humano específico "Sam”. Cada momento que um membro do time pensa sobre as funcionalidades potenciais e diz “usuários devem gostar disso" você pode apontar para o persona e perguntar "o Sam vai usar isso?”. Os vagos "usuários" alvo do design e que são capazes de qualquer coisa se tornam um consumidor específico com coisas que necessita e usa, assim como coisas que não quer e não pode usar. Repentinamente, priorizar funcionalidades se torna um trabalho fácil. (WODTKE, 2003, pág. 165) 


\section{- Cenários}

São pequenas histórias que relatam como os usuários vão idealmente usar o website. Eles descrevem o ambiente do usuário, que situação o motivou a utilizar o website e como ocorreu toda a sua interação. São uma simplificação dos métodos de análise de tarefas muito utilizados em estudos de usabilidade e funcionam como uma ferramenta de design, de avaliação e de comunicação (SHIPLE, 2001; ROSENFELD e MORVILLE, 2002; DIJCK, 2003; WODTKE, 2003; BUSTAMANTE, 2004).

$O$ valor dos cenários é que eles relatam as funções do website em relação aos objetivos do usuário, o que torna a discussão mais fácil e as decisões de design mais acertadas. Cenários são especialmente úteis em combinação com personas: os personas descrevem as motivações e objetivos, os cenários descrevem as tarefas concretas. (DIJCK, 2003, pág. 66)

\section{- Diagramas de Overview}

São diagramas com uma visão geral e hierárquica da arquitetura de informação do website, onde as idéias começam a tomar forma. Metáforas, personas e cenários são boas ferramentas para estimular a criatividade e a colaboração, mas são caóticos e desorganizados. Diagramas de overview organizam as idéias e criam uma visão mais prática e factível (REISS, 2000; ROSENFELD e MORVILLE, 2002; WODTKE, 2003).

REISS (2000) e WODTKE (2003) sugerem também outros dois tipos de diagramas que auxiliam no processo criativo do arquiteto de informação: mindmaps (representa a associação de idéias) e o site path diagram (representa o caminho que os usuários, representado por personas, percorrem no website).

\section{- Mock-up das principais páginas}

São esboços muito simplificados das páginas, especificando seus elementos principais. Eles retratam os elementos necessários em cada página e por isso são menos abstratos que os diagramas de overview. Sua função é visualizar e comunicar de forma 
clara as implicações da arquitetura de informação no nível da página (ROSENFELD e MORVILLE, 2002; WODTKE, 2003).

\subsection{Técnicas para a avaliação dos conceitos}

Após desenvolver os conceitos e regras dos quatro sistemas que formam a arquitetura de informação do website, a próxima atividade na fase de Concepção consiste em avaliá-los para verificar se são factíveis de implementação. Para ROSENFELD e MORVILLE (2002), a avaliação dos conceitos envolve a resposta a três perguntas:

- Atende as necessidades de negócio?

- É viável técnica e operacionalmente?

- É fácil de usar?

Segundo esses autores, as respostas das duas primeiras perguntas é obtida com os profissionais da empresa que foram entrevistados na fase de Pesquisa. Como foram esses profissionais que definiram a proposta de valor do website e os requisitos e diretrizes para a implementação, eles são as pessoas mais adequadas para avaliar se a arquitetura de informação proposta atende as necessidades de negócio e é viável técnica e operacionalmente.

Para responder a terceira pergunta, "é fácil de usar?", diversos autores sugerem a realização de avaliações de usabilidade com técnicas provenientes da Interação HumanoComputador (REISS, 2000; ROSENFELD e MORVILLE, 2002; DIJCK, 2003; SAPIENT apud MORROGH, 2003; WODTKE, 2003; BUSTAMANTE, 2004). A seguir são apresentadas as técnicas de avaliação de usabilidade utilizadas em projetos de arquitetura de informação mais citadas na literatura:

\section{- Análise Heurística}

É um método de avaliação de usabilidade no qual especialistas em usabilidade (inspetores) inspecionam as características da interface (especificações, protótipos ou o produto final) e analisam se elas vão contra as heurísticas (princípios gerais) de usabilidade. Sua função é avaliar se o website segue os princípios de um bom design e 
consequentemente, se possui boa usabilidade. Esse método pode ser aplicado nos primeiros esboços de telas do projeto para verificar se nenhuma heurística está sendo desrespeitada. Com essa técnica é possível avaliar o design dos quatro sistemas da arquitetura de informação (organização, navegação, rotulação e busca).

Ainda são poucos e preliminares os estudos de heurísticas específicas para a Arquitetura de Informação de websites. Destacam-se as heurísticas para Arquitetura de Informação (ROSENFELD, 2004a), as heurísticas para sistemas de busca (ROSENFELD, 2004b) e o Navigation Stress Test (INSTONE, 2004).

\section{- Card Sorting}

Método de teste com usuários para explorar como eles agrupam itens. Consiste em entregar ao usuário uma pilha de cartões, cada um deles representando um conteúdo do website, e solicitar que ele os organize. Seu objetivo é gerar a estrutura global da informação ou avaliar uma estrutura já existente, por isso a técnica é indicada para auxiliar o projeto dos sistemas de organização e rotulação. Variantes dessa técnica podem ser usadas tanto para auxiliar a definir esses sistemas quanto para validá-los.

MAURER e WARFEL (2004) é uma das melhores referências sobre o uso do card sorting em projetos de arquitetura de informação. Esses autores descrevem a técnica e suas variantes com detalhes.

\section{- Protótipos em papel}

Método de teste com usuário no qual são empregados protótipos da interface com baixa fidelidade elaborados com desenhos em papel. Seu objetivo é avaliar, através de um teste com usuários, os sistemas de organização, de navegação, de rotulação e de busca. Serve também como uma ferramenta de comunicação para facilitar o entendimento do design por toda a equipe do projeto.

É a técnica que apresenta os maiores avanços, com diversas variantes e casos de aplicação documentados. SNYDER (2003) é uma das mais completas referências sobre essa técnica. 


\subsubsection{A fase de Especificação}

A fase de Especificação tem a função de detalhar e documentar os conceitos definidos na fase de Concepção produzindo uma especificação detalhada dos quatro sistemas de organização, de navegação, de rotulação e de busca aplicada aos conteúdos que o website irá oferecer. Nessa fase são produzidos os diversos documentos de especificação da arquitetura de informação, como o sitegrama, os fluxos de navegação, os wireframes e o vocabulário controlado.

A maioria dos autores pesquisados na literatura (REISS, 2000; SHIPLE, 2001; ROSENFELD e MORVILLE, 2002; DIJCK, 2003; WODTKE, 2003; SAPIENT apud MORROGH, 2003) também dedicam etapas exclusivamente para a fase de Especificação nas suas metodologias, guias e tutoriais. A exceção mais marcante é BUSTAMANTE (2004) que não diferencia essa fase da fase de Concepção, como mostra Figura 7.

O que se nota na metodologia desse autor é uma grande mistura das fases de Concepção e Especificação. De fato a fase de Especificação nada mais é que o detalhamento dos diagramas (diagrama de overview e mock-up das páginas) produzidos na fase anterior. Porém a separação em fases distintas reforça a importância de avaliar e validar os conceitos antes de produzir uma extensa documentação reduzindo assim possíveis retrabalhos.

Na metodologia proposta por ROSENFELD e MORVILLE (2002), é fase de Design corresponde à fase de Especificação do quadro de referência, como visto na Figura 7. Segundo esses autores, nessa etapa são produzidos todos os documentos que guiarão o trabalho dos profissionais responsáveis por implementar o website.

Design é onde você transforma uma estratégia de alto nível em uma arquitetura de informação, criando esquemas detalhados, wireframes e meta-dados que serão utilizados por designers gráficos, programadores, redatores e o time de produção. É nessa etapa tipicamente onde os arquitetos de informação fazem a maior parte do trabalho, mas quantidade não significa qualidade. Uma etapa de Design [fase de Especificação] mal executada pode ruir a melhor das estratégias [fase de Concepção].(ROSENFELD e MORVILLE, 2002, pág. 212). 
SAPIENT (apud MORROGH, 2003) também denomina de Design a fase destinada à fase de Especificação (Figura 7). Nessa etapa, além da elaboração de uma documentação detalhada da arquitetura de informação, são realizados mais testes com o usuário e é revisto o documento que registrou os conceitos elaborados na fase de Concepção.

Ao se elaborar uma documentação detalhada da arquitetura de informação do website, todos os conceitos definidos passam naturalmente por uma análise em cada um dos seus casos de uso, o que pode causar alterações. Dependendo do impacto e da importância dessas alterações, novos testes com usuários podem ser necessários para validar as modificações nos conceitos, o que justifica a presença de uma atividade de avaliação da usabilidade na fase de Especificação na metodologia da SAPIENT.

Outros autores (REISS, 2000; SHIPLE, 2001; DIJCK, 2003; WODTKE, 2003) também dedicam bastante atenção à fase de Especificação e sugerem modelos de documentos para essa fase, os quais têm a função de modelar o website provendo visões múltiplas para diferentes audiências, semelhante as tradicionais ferramentas de modelagem utilizadas na Engenharia de Software.

YOURDON (1990, pág. 83) aponta que existem três motivos básicos na Engenharia de Software para a construção de modelos:

- Focalizar a atenção nas características mais importantes do sistema dando menos atenção às menos importantes.

- Discutir modificações e correções nos requisitos do usuário com baixo custo e mínimo risco.

- Verificar se o analista conhece corretamente o ambiente do usuário e documentou de tal maneira que os projetistas e programadores podem construir o sistema.

Esse autor também recomenda que se utilize modelos gráficos por três motivos: conseguem englobar uma imensa quantidade de informações de forma concisa e compacta, permitem que o sistema seja visualizado de forma subdividida e hierárquica e têm redundância mínima. 
Modelos gráficos, como os utilizados na Engenharia de Software, se baseiam em vocabulários visuais próprios. Vocabulários visuais são um conjunto de símbolos gráficos, cada qual representando um conceito relevante ao sistema, e regras que definem quando e como utilizar cada símbolo. Alguns exemplos de vocabulários visuais são os diagramas de fluxo de dados (DFD), diagramas de entidade-relacionamento (ER) e os fluxogramas.

A maioria dos documentos propostos pelos diversos autores (REISS, 2000; SHIPLE, 2001; ROSENFELD e MORVILLE, 2002; DIJCK, 2003; WODTKE, 2003) para a fase de Especificação são modelos gráficos com vocabulários visuais próprios, inspirados nos modelos da Engenharia de Software.

Existe bastante concordância entre os autores quanto aos principais tipos de documentos necessários nessa fase: o sitegrama, o fluxo das transações, os wireframes e o vocabulário controlado. Esses tipos de documentos estão descritos a seguir.

\subsubsection{Sitegrama e Fluxo das Transações}

O sitegrama (também chamado de mapa do site) e o fluxo das transações são os documentos com maior nível de abstração entre os tipos de documentos de especificação da Arquitetura de Informação. Juntos eles têm a função de apresentar uma visão geral do website mostrando o relacionamento entre as páginas (REISS, 2000; ROSENFELD e MORVILLE, 2002; WODTKE, 2003; DIJCK, 2003).

Provavelmente o sitegrama é o mais clássico dos documentos da Arquitetura de Informação. Trata-se de um diagrama que representa a organização hierárquica do website e que contém todas as páginas de conteúdo e a entrada de todas as transações (WODTKE, 2003). Normalmente são elaborados através de diagramas em árvore, especialmente para se representar hierarquias. "Eles [os sitegramas] fornecem um significado para um grupo de pessoas conversarem a respeito do website e terem uma representação visual dele" (DIJCK, 2003, pág. 108).

O fluxo das transações é um diagrama que representa o modelo de interação do usuário ao executar as transações do website. Contém todas as páginas das transações incluindo mensagens de erro e sucesso. Para essa representação são utilizados fluxogramas 
que indicam como ocorrem as transações entre as páginas (REISS, 2000; ROSENFELD e MORVILLE, 2002; WODTKE, 2003; DIJCK, 2003).

Segundo GARRETT (2002), ambos os documentos são utilizados também como ferramentas de comunicação com a equipe de projeto e por isso atendem os diferentes propósitos dos diferentes profissionais:

- Arquitetos de Informação: usam para organizar as informações e apresentar a hierarquia e a navegação entre as páginas do website.

- Diretores de Arte e Designers Gráficos: usam para definir o número de tipos de telas e para desenhar graficamente os menus do website.

- Redatores e Produtores de Conteúdo: usam para compreender os requisitos de conteúdo do website

- Programadores e Analistas: usam para definir os requisitos técnicos e a modelagem do software e do banco de dados do website.

GARRETT (2002) é o autor da proposta de vocabulário visual para elaboração de sitegramas e fluxo das transações mais popular e mais citada na literatura. Trata-se de um conjunto de 22 símbolos diferentes que representam os principais conceitos de Arquitetura de Informação e Design de Interação. Esse conjunto é independente de ferramentas (pode ser utilizado em diversos softwares gráficos e até em desenhos a mão livre) e sua descrição original já foi traduzida para diversos idiomas (chinês, japonês, russo, espanhol, italiano, francês, alemão e português).

\subsubsection{Wireframe}

O wireframe é um diagrama que especifica uma página do website. Ele representa uma página definindo seus elementos, a hierarquia entre eles, seus agrupamentos e suas importâncias relativas. Seu objetivo é especificar a implementação da página e comunicar o conteúdo e as funções de cada página para discussão com a equipe do projeto (REISS, 2000; ROSENFELD e MORVILLE, 2002; WODTKE, 2003; DIJCK, 2003). 
Um wireframe (ou esquema de página, como é chamado às vezes) é um esboço básico de uma página individual, desenhado para indicar os elementos da página, seus relacionamentos e suas importâncias relativas. Ele é muito parecido com a armação que um escultor faz antes de adicionar barro: ele dá forma e prove suporte. (WODTKE, 2003, pág. 284)

Segundo ROSENFELD e MORVILLE (2002), assim como o sitegrama e o fluxo das transações, o wireframe é utilizado com diferentes propósitos pelos membros da equipe de projeto:

- Arquitetos de Informação: usam para especificar cada página do website.

- Diretores de Arte e Designers Gráficos: utilizam para definir a linha gráfica do website e o layout de cada página.

- Redatores e Produtores de Conteúdo: usam para especificar os conteúdos das páginas.

- Empresa contratante: usa para validar se o conteúdo das páginas atende aos requisitos do projeto.

O wireframe é o primeiro documento que começa a dar forma ao layout gráfico das páginas, por isso ele pode ser um forte motivo de discussão entre o arquiteto de informação e o designer gráfico. Apesar de não ser seu foco, o wireframe apresenta uma sugestão de organização espacial para o layout da página, o que pode restringir a liberdade criativa do designer gráfico. Assim WODTKE (2003) sugere que o wireframe seja fruto de um trabalho de equipe, criado em conjunto pelo arquiteto de informação e pelo designer gráfico. Esse tipo de abordagem minimiza divergências entre esses profissionais e produz um wireframe com maior fidelidade em relação ao layout final da página. A elaboração de layouts de alta fidelidade é mais custosa, porém eles são mais facilmente compreendidos, especialmente por pessoas pouco familiarizadas com esse tipo de documento.

Não existe uma proposta de vocabulário visual para wireframes. Cada autor (REISS, 2000; ROSENFELD e MORVILLE, 2002; WODTKE, 2003; DIJCK, 2003) tem seu conjunto próprio de símbolos. O que se percebe de comum é a existência de três níveis ou camadas diferentes na especificação do wireframe. A primeira camada é onde ocorre a 
representação gráfica dos elementos. Nela os elementos são desenhados com o grau de fidelidade escolhido para o projeto. A segunda camada identifica esses elementos e mostra seus agrupamentos e hierarquias. Por fim, a última camada descreve os elementos, suas funções e os detalhes da sua implementação.

\subsubsection{Vocabulário Controlado}

Vocabulário controlado é um instrumento bastante utilizado pela Ciência da Informação em trabalhos de classificação. Trata-se de uma linguagem artificial, ou seja, uma linguagem construída com base em um conjunto de regras prescritivas estabelecidas anteriormente a sua utilização, e como toda linguagem artificial, não comporta exceções (WERSIG apud CAMPOS e colab. , 2004).

Na Arquitetura de Informação a função dos vocabulários controlados é especificar os rótulos que podem ser utilizados no website e os meta-dados utilizados na indexação do sistema (ROSENFELD e MORVILLE, 2002).

ROSENFELD e MORVILLE (2002) e FAST e colab. (2003) indicam a existência de quatro tipos de vocabulários controlados, que variam conforme o grau de complexidade e o grau de relacionamento entre seus termos. Sintetizando esses autores, os tipos são os seguintes:

- Anéis de Sinônimos (Synonym Rings): Trata-se de um conjunto de palavras definidas como sinônimas para os propósitos de uma busca. É o mais simples dos tipos de vocabulário controlado e se baseia em um único tipo de relacionamento entre os termos, a equivalência ou sinonímia. $\mathrm{Na}$ prática as palavras que compõem um anel de sinônimos nem sempre são realmente sinônimas. Podem conter termos abrangentes, termos específicos, termos científicos, termos populares, abreviações e até erros de ortografia e digitação, porém, para os propósitos do website, todos os termos são considerados sinônimos. A função dos anéis de sinônimos é aumentar a relevância dos resultados das buscas feitas no website para os diferentes tipos de usuários, mesmo que eles utilizem diferentes termos para se referir ao mesmo conceito. 
- Arquivos de Autoridade (Authority Files): É um conjunto de termos equivalentes como os anéis de sinônimos com a diferença que um dos termos é definido como preferencial. A função dos arquivos de autoridade é compreender as diferentes variantes da linguagem do usuário e traduzi-las para os termos utilizados no website. Normalmente os termos preferenciais se transformam nos rótulos utilizados nas páginas e no sistema de navegação.

- Esquemas de Classificação: Trata-se de uma organização hierárquica de termos preferenciais. Também chamados de taxonomias, esses esquemas são utilizados para montar os menus hierárquicos do sistema de navegação e para indexar a informação.

- Tesauro: É o tipo mais complexo de vocabulário controlado porque contém três tipos de relacionamento entre os termos: equivalência, hierarquia e associação. Sua função é criar uma rede semântica que estruture todo o conhecimento. Os tesauros auxiliam na indexação dos termos no mecanismo de busca, na construção dos menus hierárquicos, na definição dos rótulos dos elementos nas páginas e na definição dos cross contents.

A construção de vocabulários controlados é bastante trabalhosa, especialmente no caso do tesauro, assim é comum utilizar vocabulários controlados prontos e apenas adaptálos às necessidades do website (ROSENFELD e MORVILLE, 2002).

Por ser um campo novo é comum que as pessoas, especialmente as sem experiência com projetos de websites, não sejam familiarizadas com os documentos da Arquitetura de Informação. Isso pode dificultar a compreensão dos documentos ocasionando erros na fase de Implementação. Assim ROSENFELD e MORVILLE (2002) recomendam, para minimizar tais erros, que a primeira apresentação desses documentos para qualquer público seja feita em reuniões presenciais, de modo a solucionar dúvidas e estabelecer uma melhor comunicação. 
Já existem algumas ferramentas $\operatorname{CASE}^{19}$ específicas para automatizar a elaboração e manutenção dos documentos de Arquitetura de Informação, em especial para elaborar o sitegrama, o fluxo das transações e os wireframes. Alguns exemplos são o Axure, Elegance Tech, iRise, Serena, Simunication e Sofea (McDOWELL, 2006). Porém esses softwares ainda são pouco difundidos. As ferramentas mais utilizadas pelos arquitetos de informação para elaborar seus documentos de especificação são Microsoft Visio, Microsoft Word, Microsoft Excel, Microsoft Power Point, Omni Graffle e Ilustrator (ROSENFELD e MORVILLE, 2006b). A elaboração dessa documentação é a etapa mais trabalhosa nos projetos de arquiteto de informação, assim, a pesquisa, o desenvolvimento e a difusão de ferramentas CASE que automatizem esse trabalho merece ser estimulada.

\subsubsection{A fase de Implementação}

A fase de Implementação é o momento em que o website é construído. Nessa fase todas as especificações elaboradas na fase anterior são desenvolvidas e implementadas transformando as idéias em realidade.

Nas propostas de metodologias de projeto de arquitetura de informação pouca atenção é dedicada a essa fase. REISS (2000), SHIPLE (2000), WODTKE (2003) e DIJCK(2003) não fazem quaisquer comentários sobre a fase de Implementação, possivelmente porque essa fase não demanda grandes esforços criativos do arquiteto.

ROSENFELD e MORVILLE (2002) dedicam à fase de Implementação uma fase com o mesmo nome (Implementação ou Implementation), como mostra a Figura 7, porém também reservam poucos comentários a ela. Segundo esses autores, nessa fase os demais profissionais envolvidos com o projeto (designers gráfico, redatores, programadores, etc.) constroem o website seguindo as especificações. E já que "nenhum arquiteto consegue antecipar tudo" eles advertem que dúvidas e problemas surgem durante o trabalho desses profissionais e o arquiteto precisa solucioná-los. Porém se as fases anteriores foram

\footnotetext{
${ }^{19}$ CASE é a abreviação de Computer-Aided Software Engineering ou Engenharia de Software auxiliada por Computador. Essa denominação é utilizada para os programas de computador que engenheiros e analistas de sistemas utilizam na modelagem de softwares.
} 
cumpridas corretamente, se os conceitos e as especificações foram bastante discutidos e validados, não deverão surgir grandes problemas. Nenhuma técnica ou ferramenta é citada por esses autores para essa fase.

Na metodologia de BUSTAMANTE (2004), a fase de Produção e Implementação (Producción y Implementación) corresponde a fase de Implementação do quadro de referência (Figura 7). Esse autor também dedica pouca atenção a essa fase, apenas cita que seu êxito depende da qualidade das fases anteriores e que deve se prestar atenção aos prazos, tempos de execução e ao cumprimento das especificações elaboradas. Ele também não sugere nenhuma técnica ou ferramenta para essa fase.

Na metodologia da SAPIENT (apud MORROGH, 2003) a fase de Implementação é dividida em duas fases, como aponta a Figura 7. A primeira fase, Validar e testar o design (Validate and test the design), trata do acompanhamento da construção do website propriamente dito, na qual o papel do arquiteto de informação é resolver conflitos, fazer ajustes no design, atualizar a documentação, participar dos testes funcionais do website e controlar a qualidade do projeto.

A segunda fase, Transferir Conhecimento (Transfer knowledge), é destinada a difundir o conhecimento adquirido com o projeto. De um lado transfere-se o conhecimento do arquiteto de informação aos profissionais que irão cuidar da administração do website e das suas manutenções futuras. Do outro lado é elaborado um estudo de caso do projeto, onde são incorporados os feedbacks de métricas de acesso, dos clientes e dos usuários para registrar o conhecimento e passá-lo a outros arquitetos de informação, que os aplicarão em novos projetos.

Apesar da pouca atenção dedicada pelos autores, o que se observa é que a função do arquiteto de informação na fase de Implementação é acompanhar o trabalho de construção do website para verificar se as suas especificações foram devidamente seguidas. Nesse acompanhamento podem surgir dúvidas sobre os documentos que precisam ser explicadas. Também podem surgir alterações em detalhes da especificação que não se mostraram viáveis de implementação e por isso precisam ser modificadas. Se o trabalho nas fases de Concepção e Especificação foi bem elaborado, é pequena a 
probabilidade de surgirem mudanças nos conceitos definidos para o website e assim as alterações serão pequenas e pontuais.

Não são citadas na literatura técnicas ou ferramentas para essa fase. Porém técnicas de teste de software podem ser empregadas para validar se o website foi corretamente implementado, especialmente as técnicas de testes funcionais ${ }^{20}$.

\subsubsection{A fase de Avaliação}

A fase de Avaliação em um projeto de arquitetura de informação, como visto anteriormente, é importante para que o arquiteto aprenda com a experiência e melhore a qualidade dos seus trabalhos futuros. Porém vários autores (REISS, 2000; DIJCK, 2003; SAPIENT apud MORROGH, 2003; WODTKE, 2003) não dedicam quaisquer comentários a essa fase.

ROSENFELD e MORVILLE (2002) fazem poucos comentários sobre a avaliação de resultados. Na metodologia desse autores existe a fase de Administração (Administration), que faz uma pequena menção sobre o tema. Nessa fase esses autores sugerem a realização de análises sobre o website em produção através de testes com usuários seguindo uma filosofia de melhoria contínua.

A SAPIENT (apud MORROGH, 2003) resume-se a citar que métricas de acesso ao website e da aceitação do usuário são incluídas na documentação de encerramento do projeto e passadas na etapa transferência de conhecimento à outros arquitetos de informação, porém não explica como são obtidas essas métricas. Não existe menção a uma filosofia de melhoria contínua do website na metodologia da SAPIENT possivelmente porque o trabalho dessa empresa termina com o lançamento do website.

\footnotetext{
${ }^{20}$ Teste funcional é uma técnica de teste de software na qual é avaliada se todas as funcionalidades presentes no software funcionam conforme o especificado, incluindo as regras de negócio (MOLINARI, 2003, pág. 161).
} 
BUSTAMANTE (2004) reserva a última etapa da sua metodologia (Avaliações ou Evaluaciones) para etapa de Avaliação, na qual realiza a análise dos resultados do projeto. Esse autor também reforça a importância dessas análises para melhorar continuamente a organização do website e lhe dar um caráter dinâmico, que muda conforme as necessidades dos usuários. Porém esse autor não cita técnicas para avaliar os resultados do website.

SOUZA (2001) sugere uma técnica de mensuração de resultados de projetos de webdesign que pode ser aplicada em projetos de arquitetura de informação. Nessa técnica são criados indicadores a partir dos cenários de uso do website definidos na fase de Concepção. Esses cenários retratam os objetivos do usuário e o caminho que percorrem para alcançá-los, assim é mensurada a evolução dos usuários nas tarefas apontadas pelos cenários e, através de testes de usabilidade, é analisado o impacto do design nessa evolução ${ }^{21}$.

O método apresentado por SOUZA é bastante preciso, porém requer testes de usabilidade quantitativos, com uma amostra de clientes suficientemente grande para gerar indicadores estatisticamente confiáveis. Testes desse tipo costumam ter custo elevado porque normalmente possuem um custo alto por entrevistado. Além disso, a técnica avalia o design do website como um todo e não apenas a arquitetura de informação isoladamente.

A Arquitetura de Informação ainda precisa avançar nas técnicas de mensuração dos resultados de seu trabalho. Embora seja difícil encontrar tais indicadores, eles são importantes para melhorar a eficácia dos trabalhos e justificar sua importância.

O Information Architecture Institute (2003) possui uma iniciativa nessa área, na qual está desenvolvendo um projeto para criar métricas para a arquitetura de informação de um website através de questionários para medição da satisfação do usuário. Trata-se de

\footnotetext{
${ }^{21}$ Um indicador comum para medir essa evolução do usuário nas tarefas apontadas nos cenários são os clickthrow ou taxas de conversão. Esse indicador mede o percentual dos usuários que acessaram uma determinada página que seguiram para a página seguinte do cenário (SOUZA, 2001).
} 
uma técnica semelhante aos questionários já existentes para mensurar a satisfação com a usabilidade $^{22}$.

Esses questionários possuem como ponto positivo o fato de apresentarem uma medição quantitativa da usabilidade. Porém eles não apontam soluções para os problemas e se baseiam apenas na satisfação dos usuários e não na observação de como desempenharam as tarefas, o que pode trazer um componente subjetivo à análise. Independente disso, um questionário como esse será um importante instrumento para avaliar os resultados dos projetos de arquitetura de informação.

\subsection{Síntese}

Desenvolver uma metodologia eficiente para os projetos de arquitetura de informação é imperativo para orientar e organizar o trabalho dos arquitetos, para reduzir o caráter indutivo dos seus métodos e para a evolução desse novo campo. Porém a literatura sobre metodologias de projetos de arquitetura de informação ainda é escassa. São poucos os autores que se dedicam a esse trabalho e sugerem metodologias com todas as fases necessárias a um projeto de arquitetura de informação.

Foi possível observar nas sugestões de metodologias de projeto de arquitetura de informação analisadas que todas podem ser caracterizadas como processos de design porque todas apresentam as quatro fases características desse tipo de processo: Pesquisa, Concepção, Especificação e Implementação. Porém os autores dessas metodologias dedicam mais atenção às três primeiras fases e fazem poucos comentários sobre a fase de Implementação.

Outro ponto carente nas metodologias analisadas é a fase de Avaliação. É possível observar em algumas propostas a existência dessa fase, onde são sugeridas técnicas

\footnotetext{
${ }^{22}$ Alguns exemplos de questionários utilizados para medir a satisfação do usuário com a usabilidade de uma interface computacional são o SUMI - Software Usability Measurement Inventory (www.ucc.ie/hfrg/questionnaires/sumi/whatis.html), o WAMMI - Website Analysis and Measurement Inventory (www.wammi.com/whatis.html) e o QUIS - Questionnaire for User Interaction Satisfaction (http://www.lap.umd.edu/QUIS/).
} 
oriundas da Usabilidade para mensurar os resultados dos projetos. Mas os autores dedicam pouca atenção a essa fase como um todo e não apontam adaptações dessas técnicas para mensurar atributos próprios da Arquitetura de Informação.

Outro ponto comum nas metodologias propostas é a influência da abordagem do Design Centrado no Usuário da Interação Humano-Computador na Arquitetura de Informação. O ciclo interativo e iterativo sugerido nessa abordagem está presente nas metodologias assim como o emprego de técnicas de avaliação de usabilidade. Com certeza a influência dessa abordagem melhora a qualidade dos projetos de arquitetura de informação produzindo websites mais fáceis de usar.

Nota-se porém que a abordagem de Design Centrado no Usuário da Ciência da Informação têm pouca influência nas metodologias de projetos sugeridas. Com exceção de BUSTAMANTE (2004) nenhum outro autor emprega técnicas dessa abordagem nas suas metodologias. A ausência desse tipo de abordagem leva a um conhecimento superficial das necessidades de informação dos usuários e, consequentemente, a websites que não as atendam completamente. 


\section{Investigação empírica da metodologia de projetos de arquitetura de informação de websites}

Duas pesquisas de campo foram realizadas para elaborar a investigação empírica das metodologias de projetos de arquitetura de informação como foi apresentado no capítulo de introdução desse trabalho. Os resultados dessas duas pesquisas estão apresentados a seguir.

\subsection{Resultado do levantamento do perfil do arquiteto de informação das listas de discussão brasileiras}

A pesquisa para levantamento do perfil do arquiteto de informação brasileiro foi realizada entre os dias 27 de abril e 19 de maio de 2006, seguindo a metodologia descrita no capítulo 1. Foram obtidas 93 respostas, sendo que 91 foram consideradas válidas porque dois entrevistados cuja naturalidade não era a brasileira foram descartados. 
A maioria das respostas (54\%) foram de membros da lista de discussão AIfIA-pt. Não foi possível mensurar a quantidade de respostas que vieram das outras listas de discussão porque elas não informam o endereço de e-mail dos seus participantes, que foi utilizado para identificar univocamente os entrevistados.

\subsubsection{Interesse em Arquitetura de Informação}

O Gráfico 2 apresenta a distribuição das respostas à pergunta sobre o interesse do entrevistado pela Arquitetura de Informação. Observa-se que é elevado o número de pessoas interessadas em pesquisar esse campo (67\% dos entrevistados), sendo que $26 \%$ de todos os entrevistados não atuam como profissionais desenvolvendo projetos de arquitetura de informação de websites.

Entre os entrevistados, 67 declararam que atuam como profissionais no desenvolvimento de projetos de arquitetura de informação de websites. Esse grupo foi denominado "profissionais" e, por serem o foco da pesquisa, a investigação sobre ele foi mais aprofundada.

Entre os profissionais, mais da metade (55\%) declarou ter também interesse em pesquisar o campo da Arquitetura de Informação.

Gráfico 2 - Interesse dos entrevistados sobre Arquitetura de Informação

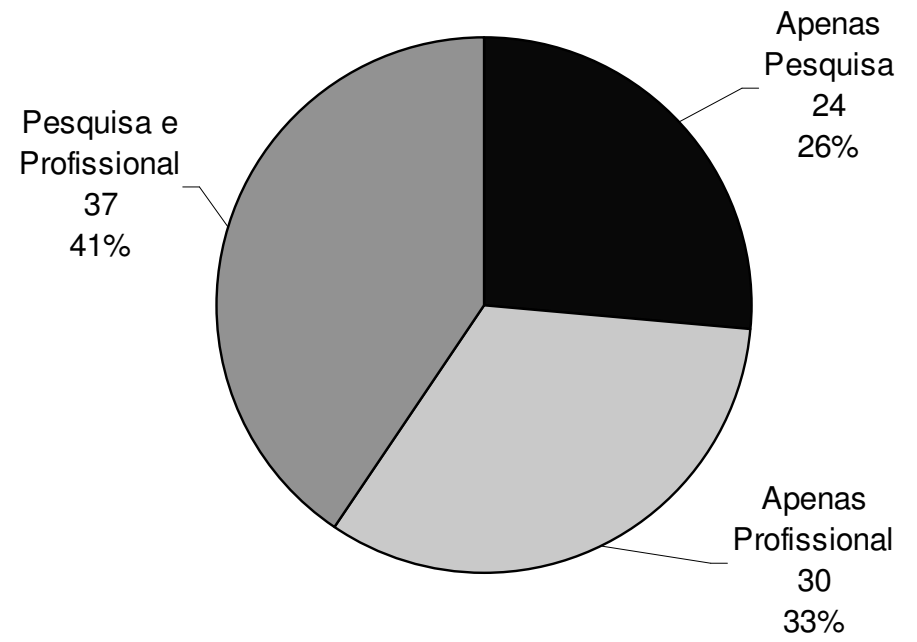




\subsubsection{Perfil Demográfico}

Os homens predominam entre os profissionais de Arquitetura de Informação (57\% dos profissionais). As mulheres apresentam menos interesse em pesquisa que os homens (74\% dos entrevistados com interesse em pesquisa são homens). O Gráfico 3 apresenta a distribuição dos entrevistados por sexo.

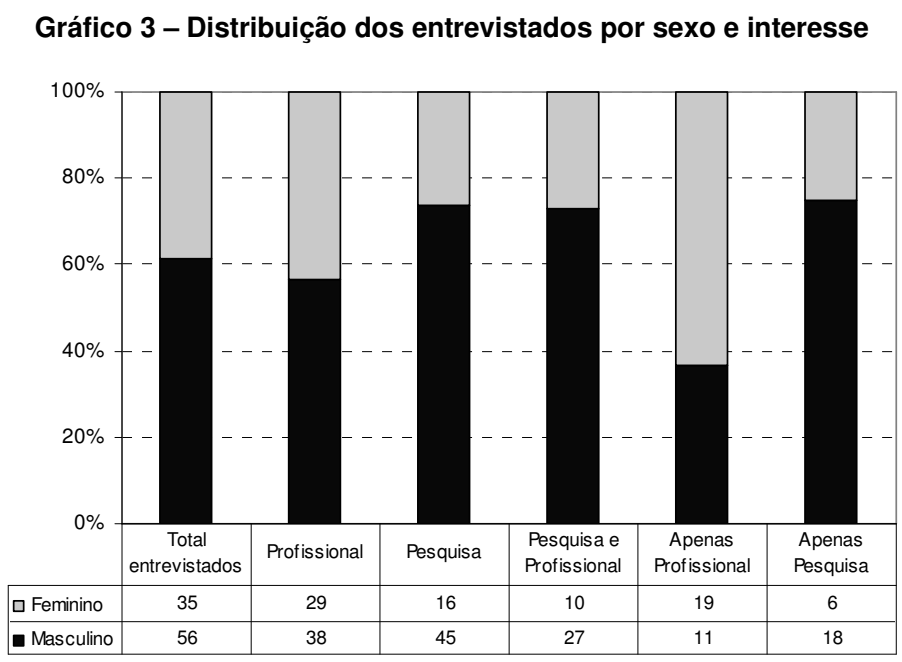

Os profissionais são na sua maioria jovens, com idade média de 29 anos. Os homens e as mulheres têm idade média muito próxima, com apenas 1 ano de diferença (29 anos para as mulheres e 30 anos para os homens). A maioria das mulheres está concentrada na faixa de 26-30 anos (62\%), enquanto a maioria dos homens está distribuída numa faixa maior, de 21 a 35 anos (79\%). O Gráfico 4 apresenta a distribuição dos entrevistados por faixa etária.

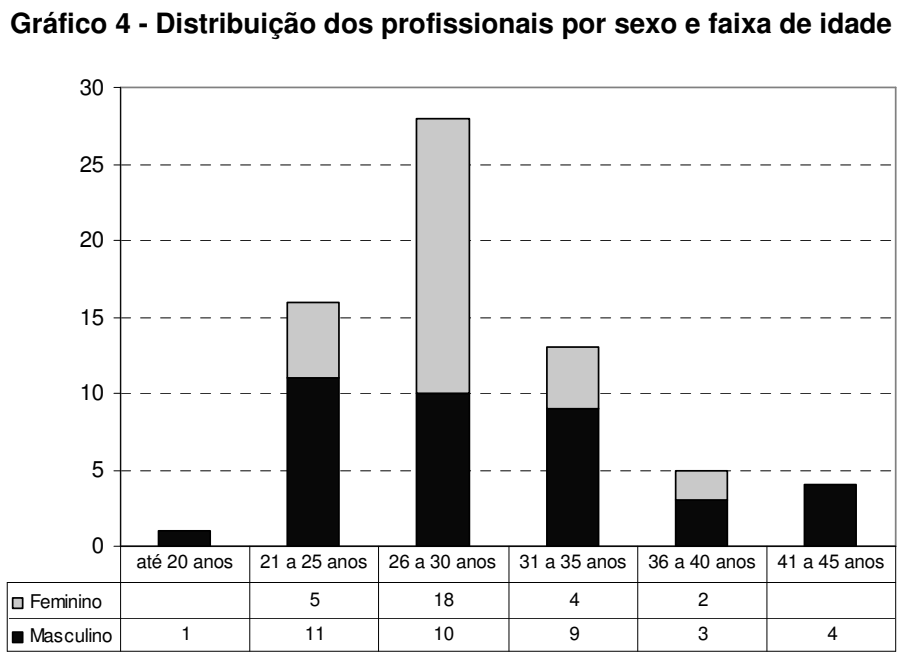


A maioria dos profissionais são solteiros (53\% dos profissionais), porém essa distribuição não se mantém em relação ao sexo. Entre os homens a predominância é de solteiros (60\% dos profissionais do sexo masculino), já entre as mulheres predominam as casadas (59\% das profissionais do sexo feminino). O Gráfico 5 mostra a distribuição dos entrevistados por sexo e estado civil.

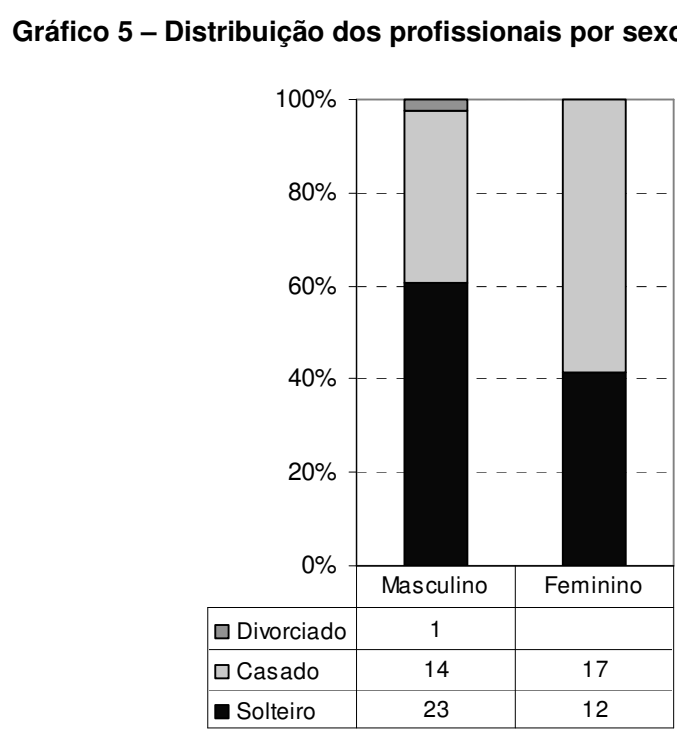

A maioria dos profissionais reside nos estados de São Paulo (46\% dos profissionais) e Rio de Janeiro (22\% dos profissionais), os maiores centros econômicos do país. Cerca de $21 \%$ dos profissionais são migrantes, sendo que a maioria dos migrantes são mulheres (71\% dos migrantes). São Paulo é o estado que recebeu a maior parte desses migrantes (50\% dos migrantes). Os profissionais residem em sua maioria nas capitais (78\% dos profissionais) e são naturais de capitais (71\% dos profissionais). A Tabela 6 mostra a quantidade de profissionais por estado e cidade.

Tabela 6 - Distribuição dos profissionais por estado e cidade de naturalidade e residência
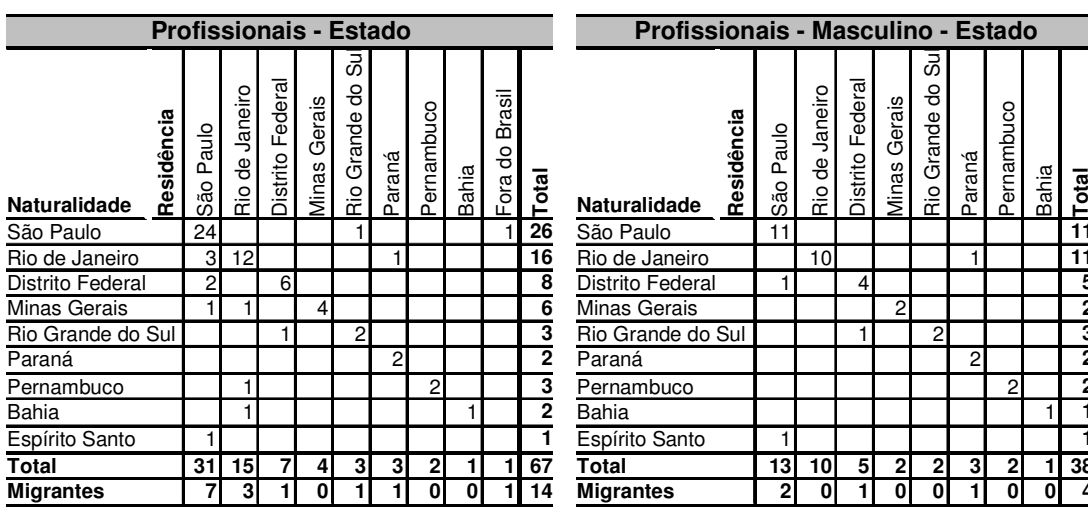
Profissionais - Feminino - Estado 


\begin{tabular}{l|c|c|c}
\hline $\begin{array}{l}\text { Profissonal } \\
\text { Residência - Cidade }\end{array}$ & Masculino & Feminino & Total \\
\hline São Paulo (capital) & 8 & 16 & 24 \\
\hline Rio de Janeiro (capital) & 8 & 4 & 12 \\
\hline Brasília (capital) & 5 & 2 & 7 \\
\hline Belo Horizonte (capital) & 2 & 2 & 4 \\
\hline Campinas & 1 & 1 & 2 \\
\hline Recife (capital) & 2 & & 2 \\
\hline Niterói & 2 & & 2 \\
\hline Jandira & 1 & & 1 \\
\hline Londrina & 1 & & 1 \\
\hline Maricá & & 1 & 1 \\
\hline Guarulhos & 1 & & 1 \\
\hline Novo Hamburgo & & 1 & 1 \\
\hline Porto Alegre (capital) & 1 & & 1 \\
\hline Curitiba (capital) & 1 & & 1 \\
\hline Cascavel & 1 & & 1 \\
\hline Salvador (capital) & 1 & & 1 \\
\hline Santa Cruz do Sul & 1 & & 1 \\
\hline Santo André & & 1 & 1 \\
\hline São Bernardo do Campo & 1 & & 1 \\
\hline Bauru & 1 & & 1 \\
\hline Fora do Brasil - EUA & & 1 & 1 \\
\hline Total & $\mathbf{3 8}$ & $\mathbf{2 9}$ & $\mathbf{6 7}$ \\
\hline & & &
\end{tabular}

\begin{tabular}{l|c|c|c}
\hline $\begin{array}{l}\text { Profissional } \\
\text { Naturalidade - Cidade }\end{array}$ & Masculino & Feminino & Total \\
\hline São Paulo (capital) & 6 & 13 & 19 \\
\hline Rio de Janeiro (capital) & 9 & 2 & 11 \\
\hline Brasília (capital) & 5 & 3 & 8 \\
\hline Belo Horizonte (capital) & 2 & 4 & 6 \\
\hline Niterói & 2 & 1 & 3 \\
\hline Santo André & 1 & 1 & 2 \\
\hline Salvador (capital) & 1 & 1 & 2 \\
\hline Recife (capital) & 2 & & 2 \\
\hline Guarulhos & 2 & & 2 \\
\hline Vitória & 1 & & 1 \\
\hline Bauru & 1 & & 1 \\
\hline Nova Friburgo & & 1 & 1 \\
\hline Pelotas & 1 & & 1 \\
\hline Petrolina & & 1 & 1 \\
\hline Londrina & 1 & & 1 \\
\hline Ribeirão Preto & & 1 & 1 \\
\hline Assis Chateaubriand & 1 & & 1 \\
\hline Duque de Caxias & & 1 & 1 \\
\hline Santa Maria & 1 & & 1 \\
\hline Campinas & 1 & & 1 \\
\hline Arroio do Tigre & 1 & & 1 \\
\hline Total & $\mathbf{3 8}$ & $\mathbf{2 9}$ & $\mathbf{6 7}$ \\
\hline & & & \\
\hline & & & 1 \\
\hline
\end{tabular}

\subsubsection{Escolaridade}

Os profissionais apresentam grau de instrução superior (75\% possuem graduação completa ou mais e $40 \%$ já realizou ou está realizando algum curso de pós-graduação, seja uma especialização ou mestrado). As mulheres possuem um grau de instrução superior aos homens (93\% das mulheres possuem graduação completa ou mais, contra $61 \%$ dos homens). O Gráfico 6 apresenta a distribuição dos profissionais pelo grau de instrução.

\section{Gráfico 6 - Grau de instrução dos profissionais}

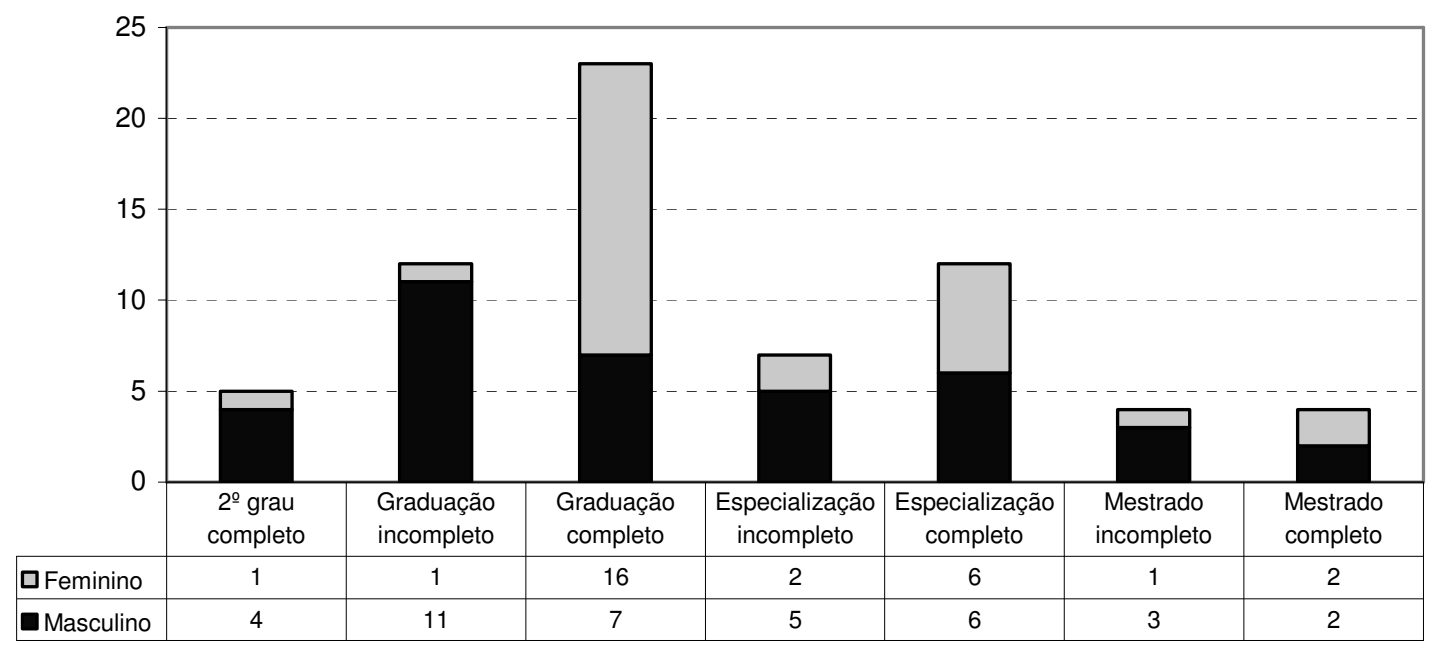


Apesar de terem um grau de instrução maior, as mulheres têm menos interesse em pesquisa que os homens, como visto no Gráfico 3.

A maioria dos profissionais com curso de graduação tem formação na área de humanas (85\% dos profissionais com graduação incompleta, completa ou mais), especialmente nos cursos de jornalismo (21\%), desenho industrial (18\%) e publicidade e propaganda (18\%). Entre os profissionais com formação na área de exatas, a maioria fez cursos relacionados com computação (78\% dos profissionais com formação na área de exatas). O Gráfico 7 e a Tabela 7 detalham os cursos e as áreas de formação dos profissionais.

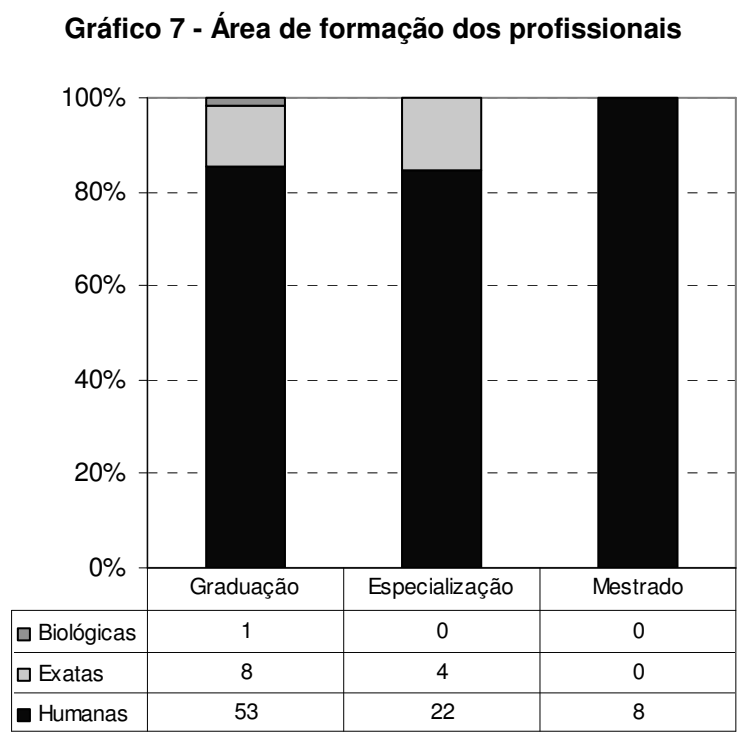


Tabela 7 - Cursos de graduação, especialização e mestrado dos profissionais

\begin{tabular}{|c|c|c|c|}
\hline \multicolumn{4}{|c|}{ Graduação - Profissionais } \\
\hline Área de formação $^{\top}$ & Curso $^{2}$ & Total & $\%$ \\
\hline \multirow{13}{*}{ Humanas } & jornalismo & 13 & $21 \%$ \\
\hline & desenho industrial & 11 & $18 \%$ \\
\hline & publicidade e propaganda & 11 & $18 \%$ \\
\hline & comunicacao & 4 & $6 \%$ \\
\hline & biblioteconomia & 3 & $5 \%$ \\
\hline & design digital (mídia digital e interafaces gráficas) & 3 & $5 \%$ \\
\hline & arquitetura & 2 & $3 \%$ \\
\hline & administracao e comercio exterior & 1 & $2 \%$ \\
\hline & arquivologia & 1 & $2 \%$ \\
\hline & desenho de moda & 1 & $2 \%$ \\
\hline & educacao artistica & 1 & $2 \%$ \\
\hline & letras - lingua portuguesa e literatura & 1 & $2 \%$ \\
\hline & web design com enfase em comercio eletronico & 1 & $2 \%$ \\
\hline \multirow[t]{6}{*}{ Exatas } & engenharia civil & 2 & $3 \%$ \\
\hline & sistemas de informacao & 2 & $3 \%$ \\
\hline & ciencia da computacao & 1 & $2 \%$ \\
\hline & matematica & 1 & $2 \%$ \\
\hline & processamento de dados & 1 & $2 \%$ \\
\hline & tecnologo em websites & 1 & $2 \%$ \\
\hline Biológicas & ciencias moleculares & 1 & $2 \%$ \\
\hline \multicolumn{2}{|l|}{ Total } & 62 & $100 \%$ \\
\hline \multicolumn{4}{|c|}{ Especialização - Profissionais } \\
\hline Área de formação $^{\top}$ & Curso $^{2}$ & Total & $\%$ \\
\hline \multirow[t]{15}{*}{ Humanas } & design de interfaces & 3 & $12 \%$ \\
\hline & marketing digital & 3 & $12 \%$ \\
\hline & mba em marketing & 3 & $12 \%$ \\
\hline & design grafico & 2 & $8 \%$ \\
\hline & comercio eletronico & 1 & $4 \%$ \\
\hline & design da informacao & 1 & $4 \%$ \\
\hline & \begin{tabular}{|l|} 
didatica e metodologia de ensino \\
\end{tabular} & 1 & $4 \%$ \\
\hline & ergodesign e avaliacao de interfaces & 1 & $4 \%$ \\
\hline & gestao de marcas & 1 & $4 \%$ \\
\hline & gestao do design & 1 & $4 \%$ \\
\hline & gestao estrategica da informacao & 1 & $4 \%$ \\
\hline & gestao estrategica e qualidade & 1 & $4 \%$ \\
\hline & jornalismo e praticas contemporaneas & 1 & $4 \%$ \\
\hline & jornalismo multimidia & 1 & $4 \%$ \\
\hline & mbkm - gestao do conhecimento e inteligencia empresarial & 1 & $4 \%$ \\
\hline \multirow[t]{3}{*}{ Exatas } & analise de sistemas & 2 & $8 \%$ \\
\hline & informatica aplicada & 1 & $4 \%$ \\
\hline & tecnologias da informacao e recuperacao da informacao & 1 & $4 \%$ \\
\hline \multicolumn{2}{|l|}{ Total } & 26 & $100 \%$ \\
\hline
\end{tabular}

\begin{tabular}{|c|c|c|c|}
\hline \multicolumn{4}{|c|}{ Mestrado - Profissionais } \\
\hline Área de formação & Curso $^{2}$ & Total & $\%$ \\
\hline \multirow[t]{8}{*}{ Humanas } & administracao com enfase em marketing & 1 & $13 \%$ \\
\hline & comunicacao e cultura midiatica & 1 & $13 \%$ \\
\hline & desenho industrial & 1 & $13 \%$ \\
\hline & design & 1 & $13 \%$ \\
\hline & gestao da informacao e da comunicacao em saude & 1 & $13 \%$ \\
\hline & gestao do conhecimento e tecnologia da informacao & 1 & $13 \%$ \\
\hline & mestrado em administracao & 1 & $13 \%$ \\
\hline & tecnologia \& sociedade & 1 & $13 \%$ \\
\hline \multicolumn{2}{|l|}{ Total } & 8 & $100 \%$ \\
\hline
\end{tabular}

1- A classificação dos cursos em áreas de formação não foi perguntada ao entrevistado, ela foi feita com base na classificação de cursos em áreas adotada pela FUVEST (2006).

2- Informado em questão aberta. 
Com relação aos cursos de pós-graduação, a área de humanas é maioria (85\% dos profissionais com especialização e 100\% dos profissionais com mestrado). Nota-se também que os profissionais buscam cursos de pós-graduação na mesma área de seus cursos de graduação. A maioria dos profissionais com curso de especialização na área de humanas também fez curso de graduação na área de humanas (95\% dos profissionais com curso de especialização na área de humanas), e a maioria dos profissionais com curso de mestrado na área de humanas também fez graduação na área de humanas (88\% dos profissionais com mestrado na área de humanas). O Gráfico 8 mostra a relação entre os cursos de graduação e pós-graduação dos profissionais.

\section{Gráfico 8 - Área de formação dos profissionais: Graduação x Pós-Graduação}

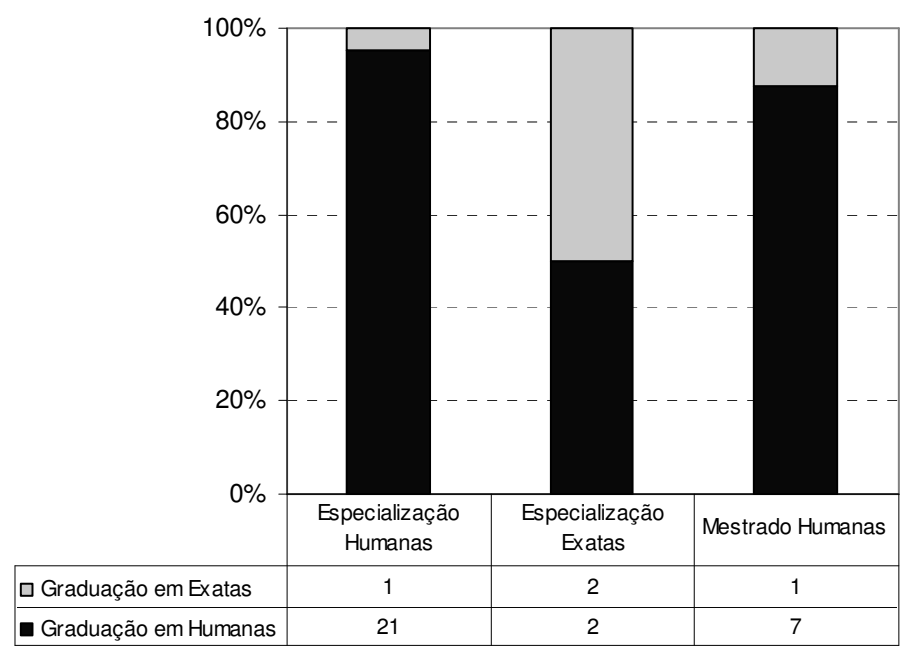

A diversidade de cursos de graduação entre os profissionais mostra que diferentes disciplinas encontram eco na Arquitetura de Informação, comprovando o seu caráter multi-disciplinar citado no capítulo 3. Porém cada profissional individualmente busca se especializar na mesma área de conhecimento do seu curso de graduação, fazendo com que ele próprio não tenha uma formação multi-disciplinar.

A formação dos profissionais é muito pulverizada entre as instituições de ensino no Brasil. Nenhuma delas formou um número significativo de profissionais, como mostra a Tabela 8. 
Tabela 8 - Instituições de ensino citadas pelos profissionais

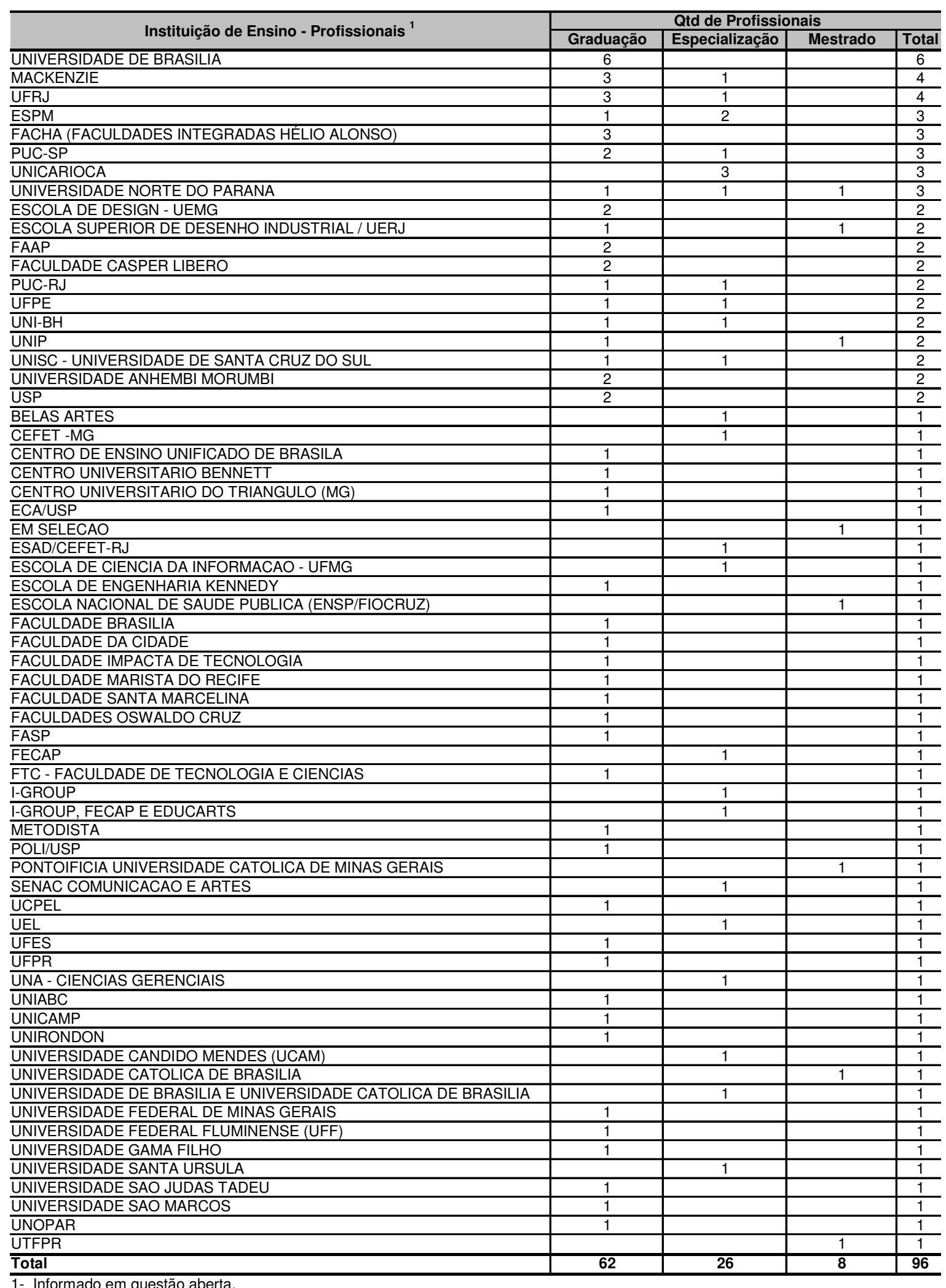

1- Informado em questão aberta. 
Vale notar que é baixo o interesse das instituições de ensino brasileiras sobre a Arquitetura de Informação. No diretório dos grupos de pesquisa no Brasil (CNPQ 2006) foi encontrada apenas uma instituição acadêmica com linha de pesquisa sobre Arquitetura de Informação. Trata-se do departamento de Ciências da Informação e Documentação da Universidade de Brasília, que lançou em 2006 uma linha de pesquisa sobre o tema.

\subsubsection{Aprendizado de Arquitetura de Informação}

A maioria dos profissionais mencionou que desenvolveu seus conhecimentos sobre Arquitetura de Informação de forma autodidata (58\% dos profissionais). Até os que responderam que desenvolveram seus conhecimentos de outras formas, diferentes das apresentadas na questão fechada, citaram, na maioria, a forma autodidata. Entre os profissionais que responderam que realizaram cursos sobre Arquitetura de Informação (10\% dos profissionais), não houve nenhum curso que se destacou (nenhum dos cursos apresentou mais que duas respostas).

Esse número elevado de formação autodidata justifica o grande interesse dos profissionais em pesquisar o campo da Arquitetura de Informação, como foi visto no Gráfico 2. Porém aponta uma carência de cursos sobre o tema no Brasil, o que pode acarretar uma má formação dos profissionais.

O Gráfico 9 e a Tabela 9 detalham as formas com que os Arquitetos de Informação adquiriram seus conhecimentos.

Gráfico 9 - Formas como os profissionais desenvolveram seus conhecimentos sobre Arquitetura de Informação

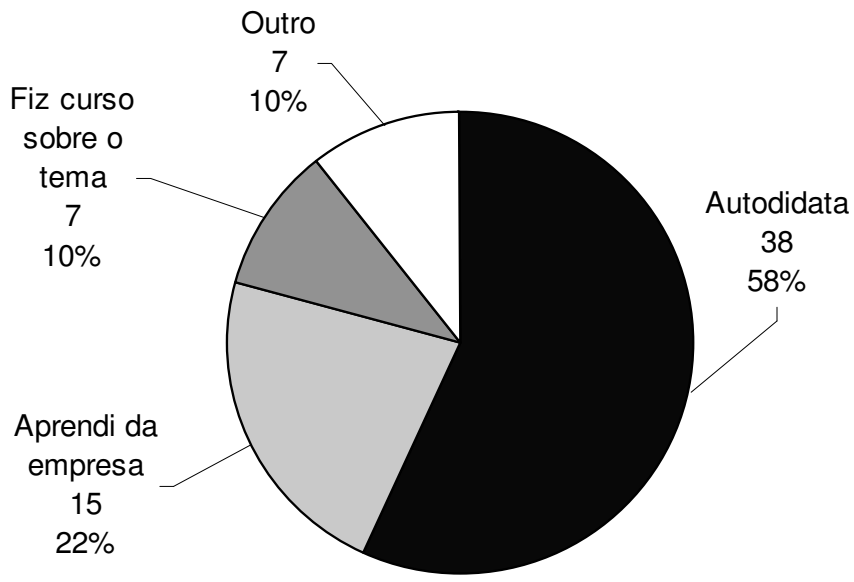


Tabela 9 - Outras formas como os profissionais desenvolveram seus conhecimentos

\begin{tabular}{l|c|c} 
Profissional - Desenvolveu & \multicolumn{2}{|c}{ Citações } \\
\cline { 2 - 3 } conhecimento - Outro - Qual $^{1}$ & Qtd & $\%$ \\
\hline Autodidata & 6 & $38 \%$ \\
\hline Aprendi da empresa & 3 & $19 \%$ \\
\hline Fiz curso sobre o tema & 3 & $19 \%$ \\
\hline Graduação & 3 & $19 \%$ \\
\hline Especialização na PUC & 1 & $6 \%$ \\
\hline Total & $\mathbf{1 6}$ & $\mathbf{1 0 0 \%}$ \\
\hline
\end{tabular}

\subsubsection{Grau de experiência}

Os profissionais possuem em média 7 anos de experiência de trabalho com Internet e 4 anos de experiência com Arquitetura de Informação, comprovando o quão recente é esse campo. A maior parte dos profissionais (40\%) tem até 2 anos de experiência com Arquitetura de Informação, o que mostra que a procura por esse novo campo vem crescendo. O Gráfico 10 mostra a distribuição dos profissionais pelos anos de trabalho com Internet e o Gráfico 11 mostra a distribuição dos profissionais pelos anos de trabalho com Arquitetura de Informação.

Gráfico 10 - Distribuição dos profissionais pelos anos de trabalho com Internet

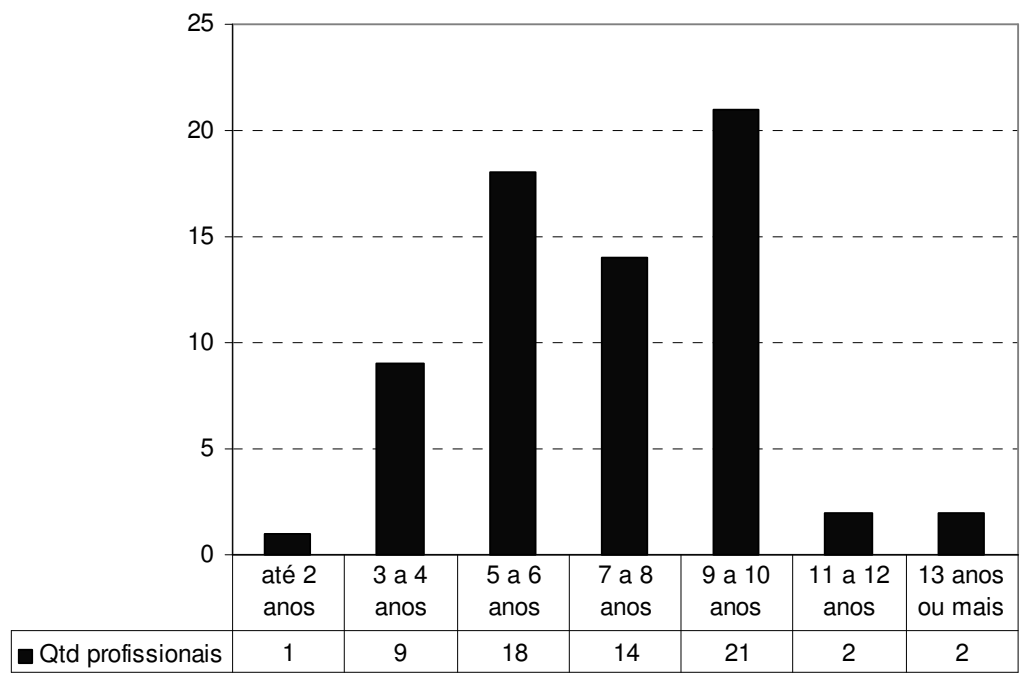


Gráfico 11 - Distribuição dos profissionais pelos anos de trabalho com Arquitetura de Informação

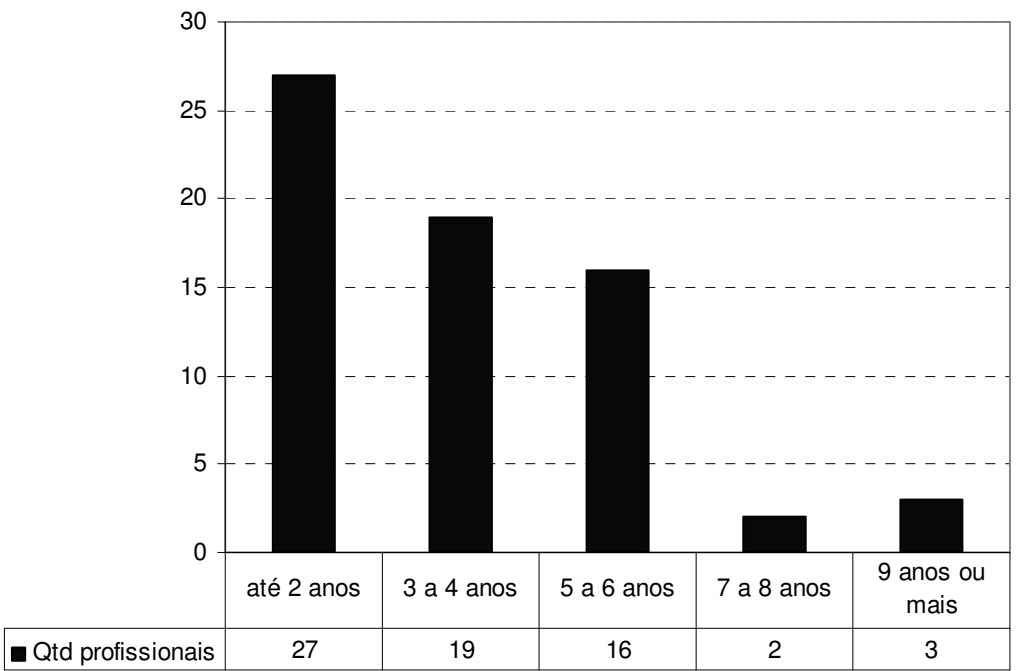

Mais da metade dos profissionais (55\%) dedica até 50\% do seu tempo de trabalho para a Arquitetura de Informação, demonstrando que esses profissionais compartilham outras funções. O Gráfico 12 apresenta a distribuição dos profissionais pela porcentagem do tempo de trabalho dedicada à Arquitetura de Informação.

Gráfico 12 - Porcentagem do tempo de trabalho dedicado à Arquitetura de Informação

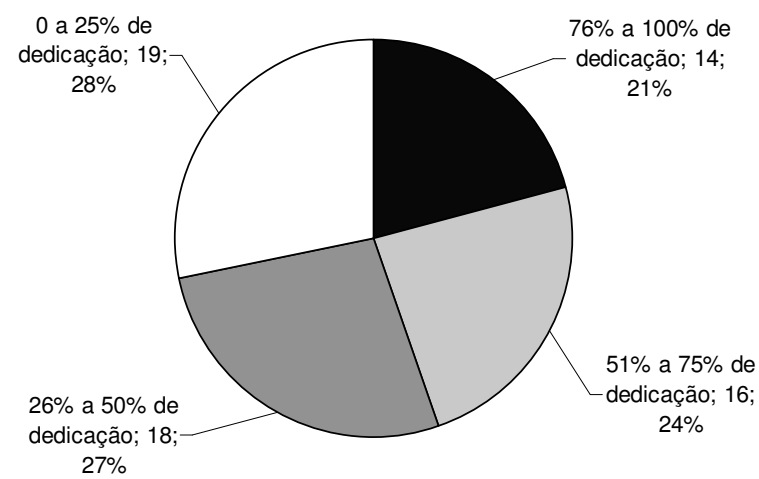

\subsubsection{Empresas, cargos e forma de contratação}

Com relação ao tipo de empresa onde trabalham, é maior a concentração de profissionais que trabalham em agências que desenvolvem websites (46\% dos profissionais). Porém existe uma quantidade grande de profissionais que trabalham em empresas cuja atividade principal não está diretamente relacionada com a Internet (Outros - 34\% dos profissionais). Provavelmente esses profissionais atuam na área responsável 
pelos websites dessas empresas. A Tabela 10 detalha a distribuição dos profissionais por tipo de empresa.

Tabela 10 - Distribuição dos profissionais por tipo de empresa

\begin{tabular}{|c|c|c|}
\hline Tipo de Empresa & Total & $\%$ \\
\hline Agência desenvolvedora de websites & 31 & $46 \%$ \\
\hline $\begin{array}{l}\text { Outro (bancos, orgãos governamentais, empresas } \\
\text { estatais, instituições de ensino, etc.) }\end{array}$ & 23 & $34 \%$ \\
\hline Desenvolvedora de Software & 7 & $10 \%$ \\
\hline Portal de conteúdo (Ex: UOL Terra, Globo.com) & 4 & $6 \%$ \\
\hline Provedor de acesso & 2 & $3 \%$ \\
\hline Total & 67 & $100 \%$ \\
\hline
\end{tabular}

Mais da metade dos profissionais possui grande vínculo com as suas empresas (CLT, Sócio da empresa e Funcionário público), como mostra a Tabela 11.

Tabela 11 - Tipo de empresa e forma de contratação dos profissionais

\begin{tabular}{l|r|c}
\hline \multicolumn{1}{|c|}{ Forma de Contratação } & Total & \% \\
\hline CLT & 33 & $49 \%$ \\
\hline Consultor & 12 & $18 \%$ \\
\hline Terceirizado & 11 & $16 \%$ \\
\hline Sócio da empresa & 4 & $6 \%$ \\
\hline Cooperativa & 2 & $3 \%$ \\
\hline Free-lance & 2 & $3 \%$ \\
\hline Funcionário público & 2 & $3 \%$ \\
\hline Estagiario & 1 & $1 \%$ \\
\hline Total & $\mathbf{6 7}$ & $\mathbf{1 0 0 \%}$ \\
\hline
\end{tabular}

A maioria dos profissionais não tem o termo "arquiteto de informação" no nome dos seus cargos (tipo de cargo Outros corresponde a 67\% do total). Entre os profissionais que possuem o termo "Arquiteto de Informação" no nome dos seus cargos, a maioria $(86 \%)$ dedica mais de $50 \%$ do seu tempo de trabalho às atividades relacionadas com a Arquitetura de Informação, sendo que metade deles tem dedicação integral (76\% a 100\% de dedicação).

O Gráfico 13 mostra da distribuição dos profissionais pelo tipo de cargo e na Tabela 12 são apresentados todos os nomes dos cargos citados pelos profissionais. 
Gráfico 13 - Distribuição dos profissionais por tipo de cargo e tempo de dedicação a Arquitetura de Informação
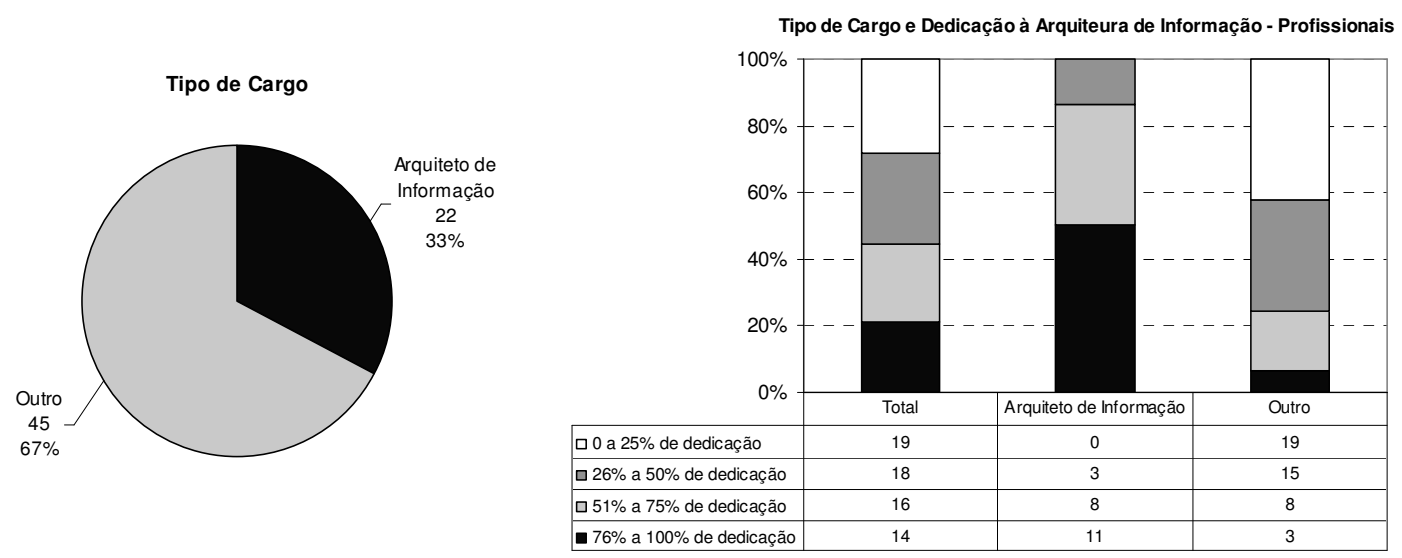

Tabela 12 - Nome dos cargos dos profissionais

\begin{tabular}{|c|c|c|c|c|c|c|}
\hline \multirow{2}{*}{$\begin{array}{l}\text { Tipo de } \\
\text { Cargo }{ }^{1}\end{array}$} & \multirow{2}{*}{ Cargo - Profissionais ${ }^{2}$} & \multicolumn{5}{|c|}{ Dedicação à Arquitetura de Informação } \\
\hline & & 0 a $25 \%$ & $26 \%$ a $50 \%$ & $51 \%$ a $75 \%$ & $76 \%$ a $100 \%$ & Total \\
\hline \multirow{16}{*}{$\begin{array}{c}\text { Arquiteto } \\
\text { de Informação }\end{array}$} & arquiteto de informacao & & & 3 & 3 & 6 \\
\hline & arquiteto de informacao e designer de interfaces & & 1 & & & 1 \\
\hline & arquiteto de informacao e designer de userinterface & & & & 1 & 1 \\
\hline & arquiteto de informacao junior & & 1 & & & 1 \\
\hline & arquiteto de informacao pleno & & & 1 & 2 & 3 \\
\hline & arquiteto de informacao pleno com enfase em planejamento & & & & 1 & 1 \\
\hline & arquiteto de informacao senior & & & & 1 & 1 \\
\hline & coordenador de arquitetura de informacao e usabilidade & & & & 1 & 1 \\
\hline & coordenadora de ai & & & & 1 & 1 \\
\hline & coordenadora de arquitetura & & & 1 & & 1 \\
\hline & estrategia \& inovacao (arquiteto de informacao e novos negocios) & & & 1 & & 1 \\
\hline & gerente da area de solucoes, inovacoes e arquitetura da informacao & & & 1 & & 1 \\
\hline & gerente de arquitetura de informacao & & & & 1 & 1 \\
\hline & gerente senior, arquitetura de informacao & & & 1 & & 1 \\
\hline & web designer / ai & & 1 & & & 1 \\
\hline & Total & & 3 & 8 & 11 & 22 \\
\hline \multirow{35}{*}{ Outro } & analista de produto & & 1 & & & 1 \\
\hline & analista de produtos pleno & & & & 1 & 1 \\
\hline & analista de sistemas & & & & 1 & 1 \\
\hline & analista web senior & & & 1 & & 1 \\
\hline & bibliotecario e gestor de conteudo & & 1 & & & 1 \\
\hline & ceo & & 1 & & & 1 \\
\hline & concept designer & 1 & & & & 1 \\
\hline & coordenador de informacao & & 1 & & & 1 \\
\hline & coordenadora de criacao & & & 1 & & 1 \\
\hline & coordenadora de projetos web & 1 & & & & 1 \\
\hline & desenvolvedor / analista de data intelligence & 1 & & & & 1 \\
\hline & designer & 5 & & & & 5 \\
\hline & designer de interacao & & & 1 & & 1 \\
\hline & designer de interface & & 2 & & & 2 \\
\hline & designer digital & & 1 & & & 1 \\
\hline & designer/socia & & 1 & & & 1 \\
\hline & diretor & & 1 & & & 1 \\
\hline & diretor de tecnologia & 1 & & & & 1 \\
\hline & diretora de projetos interativos & & & 1 & & 1 \\
\hline & diretora executiva & 1 & & & & 1 \\
\hline & docente & & 1 & & & 1 \\
\hline & editor & & 1 & 1 & & 2 \\
\hline & editor de arte - projetos especiais / webdesigner & & 1 & & & 1 \\
\hline & gerente de atendimento & & & 1 & & 1 \\
\hline & gerente de contas & 1 & & & & 1 \\
\hline & gerente de conteudo & & & 1 & & 1 \\
\hline & gerente de projetos & 2 & 1 & & & 3 \\
\hline & planejamento & 1 & & & & 1 \\
\hline & produtor executivo ii & 1 & & & & 1 \\
\hline & professor assistente iii & & 1 & & & 1 \\
\hline & programador visual web & & 1 & & & 1 \\
\hline & redator pleno & & & 1 & & 1 \\
\hline & socia & 1 & & & & 1 \\
\hline & webdesigner & 3 & & & 1 & 4 \\
\hline & Total & 19 & 15 & 8 & 3 & 45 \\
\hline Total & & 19 & 18 & 16 & 14 & 67 \\
\hline
\end{tabular}

1- A classificação dos tipos de cargos foi feita verificando se algum termo semelhante a"arquiteto de informação" aparece no nome do cargo

2- Informado em questão aberta. 


\subsubsection{Atividades executadas}

Gráfico 14 - Atividades de Arquitetura de Informação que os profissionais já fizeram

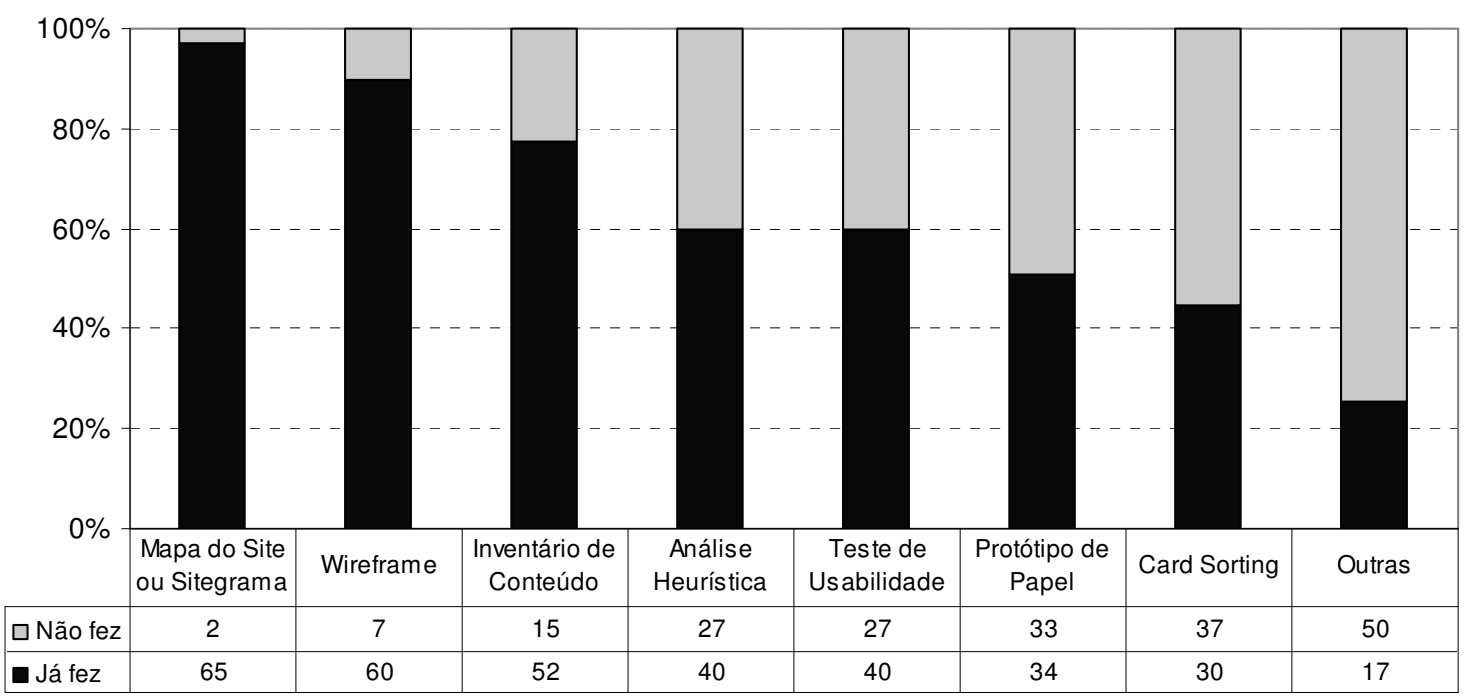

As atividades de Arquitetura de Informação mais executadas pelos profissionais são as relacionadas com a elaboração dos documentos de especificação dos websites (sitegrama e wireframe), como mostra o Gráfico 14. De fato a produção desses documentos é uma prática proposta pela maioria dos autores (REISS, 2000; SHIPLE, 2001; ROSENFELD e MORVILLE, 2002; DIJCK, 2003; WODTKE, 2003).

A maioria dos profissionais pesquisados (60\%) já fez algum tipo de avaliação de usabilidade, seja na forma analítica, por meio da a análise heurística, ou na forma empírica, utilizando os testes de usabilidade. Os testes de Card Sorting e Protótipos em Papel são pouco realizados, como mostra o Gráfico 14. Nota-se assim, que apesar da maioria dos profissionais já terem realizado avaliações de usabilidade na forma empírica, as técnicas recomendadas para os projetos de arquitetura de informação ainda são pouco difundidas.

Entre as outras atividades que os profissionais informaram na questão aberta, as mais citadas são: a formulação de estratégias ou visões macro da arquitetura de informação dos websites, a elaboração de fluxos de navegação e a construção de taxonomias e vocabulários controlados, como mostra a Tabela 13. 
Tabela 13 - Outras atividades relacionadas a Arquitetura de Informação citadas pelos profissionais

\begin{tabular}{l|c|c}
\hline \multicolumn{1}{c|}{ Outras Atividades - Quais } & Qtd de citações & $\%$ \\
\hline Estratégia e visão macro da arquitetura de informação & 5 & $10 \%$ \\
\hline Fluxo de navegação & 4 & $8 \%$ \\
\hline Taxonomia / Vocabulário controlado & 4 & $8 \%$ \\
\hline Benchmark & 3 & $6 \%$ \\
\hline Protótipos digitais / htm & 3 & $6 \%$ \\
\hline Análise de Tarefas & 2 & $4 \%$ \\
\hline Levantamento de Requisitos & 2 & $4 \%$ \\
\hline Modelo mental & 2 & $4 \%$ \\
\hline Acompanhamento da elaboração de propostas visuais & 1 & $2 \%$ \\
\hline Acompanhamento de implementação & 1 & $2 \%$ \\
\hline Análise de Resultados & 1 & $2 \%$ \\
\hline Análise técnica & 1 & $2 \%$ \\
\hline Árvore de Informação & 1 & $2 \%$ \\
\hline Avaliação cooperativa & 1 & $2 \%$ \\
\hline Classificação da informação & 1 & $2 \%$ \\
\hline Descrição técnica de telas & 1 & $2 \%$ \\
\hline Diagrama de bolas & 1 & $2 \%$ \\
\hline Entrevista com usuários & 1 & $2 \%$ \\
\hline Focus group & 1 & $2 \%$ \\
\hline Guidelines & 1 & $2 \%$ \\
\hline Levantamento de Conteúdo & 1 & $2 \%$ \\
\hline Lista de funcionalidades & 1 & $2 \%$ \\
\hline Lista de telas & 1 & $2 \%$ \\
\hline Mapeamento de padrões & 1 & $2 \%$ \\
\hline Personas & 1 & $2 \%$ \\
\hline Pesquisa qualitativa & 1 & $2 \%$ \\
\hline Posicionamento de elementos & 1 & $2 \%$ \\
\hline Protótipos Dinâmicos & 1 & $2 \%$ \\
\hline User Interaction Modeling & 1 & $2 \%$ \\
\hline Validação de sites & $\mathbf{1 8}$ & $2 \%$ \\
\hline Workflow de processos & & $2 \%$ \\
\hline Total & $100 \%$ \\
\hline 1- Informado em questão abera &
\end{tabular}

1- Informado em questão aberta.

Todas as atividades citadas na questão aberta foram classificadas nas cinco fases do quadro de referência formulado na investigação teórica: Pesquisa, Concepção, Especificação, Implementação e Avaliação. Dessa classificação nota-se que a maioria das atividades correspondem as três primeiras fases : Pesquisa (31\% das atividades citadas), Concepção (33\% das atividades citadas) e Especificação (27\% das atividades citadas). A Tabela 14 mostra a classificação dessas atividades nas fases do quadro de referência. 
Tabela 14 - Classificação das outras atividades nas fases do quadro de referência

\begin{tabular}{|c|c|c|c|}
\hline Fases da metodologia ${ }^{1}$ & Outras Atividades - Quais ${ }^{2}$ & Qtd de citações & $\%$ \\
\hline \multirow[t]{10}{*}{ Pesquisa } & Benchmark & 3 & $6 \%$ \\
\hline & Análise de Tarefas & 2 & $4 \%$ \\
\hline & Levantamento de Requisitos & 2 & $4 \%$ \\
\hline & Análise técnica & 1 & $2 \%$ \\
\hline & Avaliação cooperativa & 1 & $2 \%$ \\
\hline & Entrevista com usuários & 1 & $2 \%$ \\
\hline & Lista de funcionalidades & 1 & $2 \%$ \\
\hline & Mapeamento de padrões & 1 & $2 \%$ \\
\hline & Pesquisa qualitativa & 1 & $2 \%$ \\
\hline & Total & 15 & $31 \%$ \\
\hline \multirow[t]{7}{*}{ Concepção } & Estratégia e visão macro da arquitetura de informação & 5 & $10 \%$ \\
\hline & Diagrama de bolas & 1 & $2 \%$ \\
\hline & Personas & 1 & $2 \%$ \\
\hline & Protótipos Dinâmicos & 1 & $2 \%$ \\
\hline & User Interaction Modeling & 1 & $2 \%$ \\
\hline & Workflow de processos & 1 & $2 \%$ \\
\hline & Total & 16 & $33 \%$ \\
\hline \multirow[t]{5}{*}{ Especificação } & Fluxo de navegação & 4 & $8 \%$ \\
\hline & Taxonomia / Vocabulário controlado & 4 & $8 \%$ \\
\hline & Árvore de Informação & 1 & $2 \%$ \\
\hline & Descrição técnica de telas & 1 & $2 \%$ \\
\hline & Guidelines & 1 & $2 \%$ \\
\hline Implementação & Total & 3 & $6 \%$ \\
\hline \multirow[t]{2}{*}{ Avaliação } & Análise de Resultados & 1 & $2 \%$ \\
\hline & Total & 1 & $2 \%$ \\
\hline Total & & 48 & $100 \%$ \\
\hline
\end{tabular}

1- A classificação das outras atividades nas fases da metodologia foi feita com base no quadro de referência montado na investigação teórica.

2- Informado em questão aberta.

A classificação dessas atividades nas fases do quadro de referência corrobora com a investigação teórica, que mostrou pouca dedicação dos autores as fases de Implementação e Avaliação. Em especial, a baixa citação de atividades relacionadas à fase de Avaliação ( $2 \%$ das atividades citadas) confirma que os profissionais pesquisados não têm o hábito de analisar os resultados do seu trabalho.

\subsubsection{Existência de uma metodologia de projetos de arquitetura de informação}

Embora não seja a maioria, é alto o número de profissionais que afirmam não seguir uma metodologia em seus projetos de arquitetura de informação (45\% dos profissionais), como mostra o Gráfico 15. 
Gráfico 15 - Quantidade de profissionais que seguem uma metodologia nos projetos de arquitetura de informação

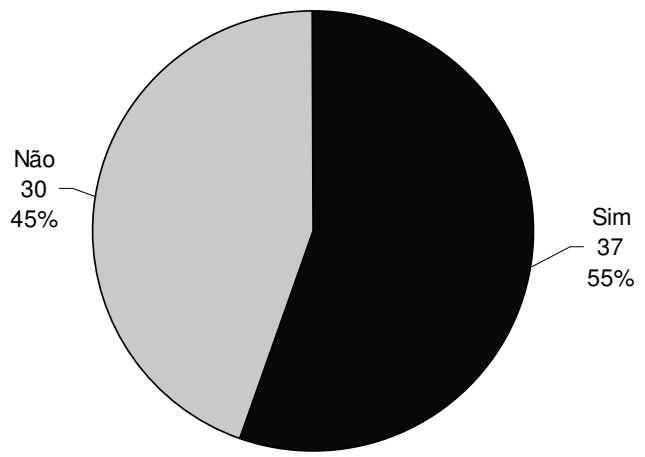

Todos os entrevistados que manifestaram seguir uma metodologia foram convidados a discriminá-las em uma questão aberta, cujas respostas foram classificadas. A contagem das citações aponta que, entre os profissionais que adotam alguma metodologia, $67 \%$ seguem uma metodologia própria, $22 \%$ seguem uma metodologia que foi possível encontrar referências na literatura e $10 \%$ segue uma metodologia que não foi possível identificar porque as respostas não mencionaram uma metodologia ou um conjunto de atividades. O Gráfico 16 apresenta a distribuição das metodologias citadas pelos profissionais.

\section{Gráfico 16 - Metodologia adotada nos projetos de arquitetura de informação}

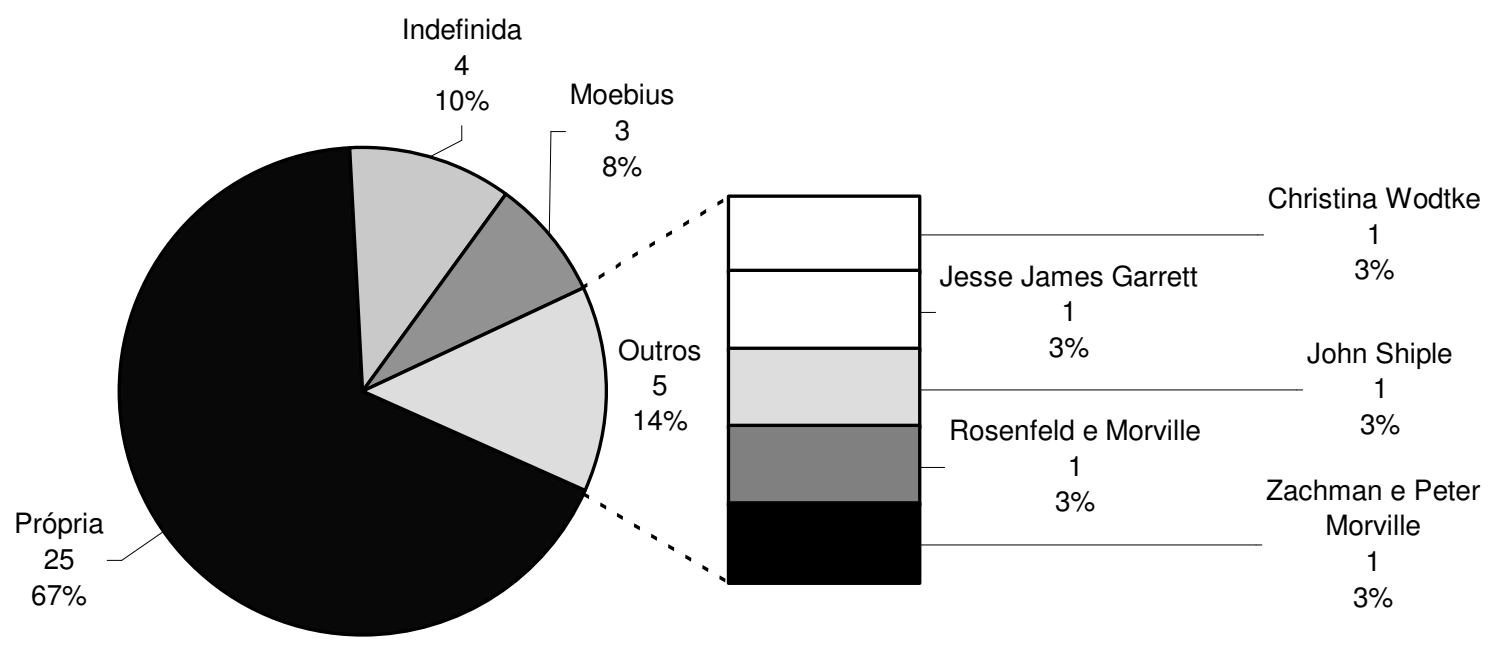

Entre as metodologias que foram possíveis encontrar referências na literatura Moebius e Jesse James Garret, não são específicas de Arquitetura de Informação. A primeira, como visto no capítulo 4 é uma metodologia para o desenvolvimento do website 
como um todo. A segunda é uma metodologia voltada para o design da experiência do usuário com o website, e se restringe às fases de Pesquisa, Concepção e Especificação.

As outras quatro, Christina Wodtke, John Shiple, Rosenfeld e Morville, Zachman e Peter Morville, se referem a metodologias de projetos de arquitetura de informação. As três primeiras foram citadas na investigação teórica e a última, Zachman e Peter Morville, se refere a um processo desenvolvido por um dos entrevistados na sua dissertação de mestrado que une o framework para o design do sistema de informação de empresas de Zachman e orientações de Peter Morville.

Intriga a baixa citação de Rosenfeld e Morville entre as metodologias de projetos de arquitetura de informação porque o livro desses autores é o que apresenta a metodologia mais completa e é o mais citado na literatura. $\mathrm{O}$ fato desse livro ainda não ter sido traduzido para a língua portuguesa pode ser um dos fatores que justifique essa baixa citação. Isso também pode indicar que a formação autodidata dos profissionais não é eficaz, uma vez que o livro mais citado na literatura está entre as metodologias menos citadas pelos entrevistados.

Com relação aos entrevistados que seguem uma metodologia própria, é possível que elas tenham sido elaboradas com base nos autores de Arquitetura de Informação vistos na investigação teórica. Mas, pela suas respostas, não houve maneira de confirmar isso.

\subsubsection{Síntese dos resultados encontrados}

A pesquisa de levantamento do perfil do arquiteto de informação das listas de discussão brasileira retrata um profissional jovem, que vive nos grandes centros metropolitanos do país e ainda está descobrindo seu campo de trabalho. É um profissional com instrução superior, formação predominante na área de humanas e que desenvolveu seus conhecimentos sobre Arquitetura de Informação de maneira autodidata.

Esse profissional tem alto vínculo empregatício nas empresas onde trabalha, mas acumula outras funções, o que não lhe permite dedicação integral a Arquitetura de Informação. 
Entre as atividades que desempenha, o profissional de Arquitetura de Informação se concentra mais naquelas classificadas nas três primeiras fases do quadro de referência visto na investigação teórica (Pesquisa, Concepção e Especificação), em especial na elaboração dos documentos de especificação da Arquitetura de Informação (sitegrama, wireframes, etc.). Poucos profissionais acompanham a implementação dos seus projetos e fazem avaliação dos seus resultados.

Quase metade dos profissionais não segue qualquer metodologia em seus projetos. Entre os que seguem, a maioria utiliza metodologias próprias desenvolvidas com base em suas experiências e estudos autodidatas.

Apesar de terem sido encontrados profissionais de várias disciplinas atuando na área de Arquitetura de Informação, esses profissionais não tem uma formação multidisciplinar. Sua formação é predominantemente na área de Humanas e que continua nos cursos de pós-graduação.

\subsection{Resultado do levantamento das dificuldades, técnicas e metodologias encontradas nos projetos de arquitetura de informação de websites}

A pesquisa de levantamento das dificuldades, técnicas e metodologias encontradas nos projetos de arquitetura de informação de websites foi realizada entre os dias 15 de agosto e 4 de setembro de 2006. Foram entrevistados 5 profissionais experientes que atuam em projetos de arquitetura de informação, selecionados entre que responderam ao questionário on-line. Os critérios de seleção desses profissionais e a metodologia empregada nessa pesquisa estão descritos na introdução desse trabalho.

Entre os participantes do levantamento do perfil do arquiteto de informação, apenas 6 atenderam a todos os critérios de seleção para essa segunda pesquisa. Todos eles foram convidados por telefone a participar da pesquisa e apenas um recusou o convite. Assim, a amostra final conteve 5 entrevistados cujas características estão descritas na Tabela 15. 
Tabela 15 - Características dos entrevistados

\begin{tabular}{|c|c|c|c|c|c|}
\hline Características & Entrevistado 1 & Entrevistado 2 & Entrevistado 3 & Entrevistado 4 & Entrevistado 5 \\
\hline Residência & São Paulo-SP & São Paulo-SP & São Paulo-SP & Rio de Janeiro-RJ & Rio de Janeiro-RJ \\
\hline $\begin{array}{l}\text { Anos que trabalha com } \\
\text { Arquitetura de } \\
\text { Informação }\end{array}$ & 6 & 5 & 6 & 6 & 7 \\
\hline $\begin{array}{l}\text { Porcentagem do tempo } \\
\text { de trabalho dedicada à } \\
\text { Arquitetura de } \\
\text { Informação }\end{array}$ & $51 \%$ a $75 \%$ & $51 \%$ a $75 \%$ & $51 \%$ a $75 \%$ & $76 \%$ a $100 \%$ & $51 \%$ a $75 \%$ \\
\hline Grau de Instrução & $\begin{array}{c}\text { Graduação } \\
\text { completo }\end{array}$ & $\begin{array}{c}\text { Graduação } \\
\text { completo }\end{array}$ & $\begin{array}{c}\text { Graduação } \\
\text { completo }\end{array}$ & $\begin{array}{c}\text { Graduação } \\
\text { completo }\end{array}$ & $\begin{array}{c}\text { Especialização } \\
\text { completo }\end{array}$ \\
\hline Formação acadêmica & - Jornalismo & - Jornalismo & $\begin{array}{l}\text { - Sistemas de } \\
\text { Informação }\end{array}$ & - Jornalismo & $\begin{array}{l}\text { - Desenho } \\
\text { industrial } \\
\text { (graduação) } \\
\text { - Ergodesign e } \\
\text { Avaliação de } \\
\text { Interfaces } \\
\text { (especialização) }\end{array}$ \\
\hline Tipo de empresa & $\begin{array}{c}\text { Agência } \\
\text { desenvolvedora } \\
\text { de websites } \\
\end{array}$ & $\begin{array}{c}\text { Agência } \\
\text { desenvolvedora } \\
\text { de websites } \\
\end{array}$ & $\begin{array}{c}\text { Desenvolvedora } \\
\text { de Software }\end{array}$ & Portal de conteúdo & $\begin{array}{c}\text { Agência } \\
\text { desenvolvedora } \\
\text { de websites } \\
\end{array}$ \\
\hline $\begin{array}{l}\text { Como desenvolveu } \\
\text { seus conhecimentos } \\
\text { sobre Arquitetura de } \\
\text { Informação } \\
\end{array}$ & - Autodidata & - Autodidata & - Autodidata & $\begin{array}{l}\text { - Aprendi na } \\
\text { empresa }\end{array}$ & $\begin{array}{l}\text { - Autodidata } \\
\text { - Curso de } \\
\text { especialização }\end{array}$ \\
\hline
\end{tabular}

As entrevistas foram realizadas individualmente com duração média de 90 minutos e foram filmadas para posterior análise. O entrevistador também fez anotações durante a entrevista.

A seguir são apresentados os resultados encontrados. Primeiro são apresentadas as metodologias adotadas pelos entrevistados, levantadas na fase I e III do roteiro de entrevista. Depois são analisadas as dificuldades enfrentadas pelos entrevistados, levantadas na fase II do roteiro.

\subsubsection{Análise da metodologia adotada pelos entrevistados}

Todos os entrevistados declararam que adotam uma metodologia de projetos de arquitetura de informação nas empresas onde trabalham, porém apenas três entrevistados têm os procedimentos de suas metodologia documentados. $\mathrm{Na}$ empresa dos outros dois entrevistados, a metodologia de projetos de arquitetura de informação está apenas no conhecimento tácito dos funcionários. Os motivos apontados para a inexistência de 
documentação da metodologia são a falta de formalismo da empresa e a falta de tempo para elaborar essa documentação.

E também todos os entrevistados declararam que concordam com a seqüência das atividades das suas metodologias. Os motivos para isso são: evoluíram a partir da experiência, a metodologia começa com visão macro vai para a visão detalhada, permite ao arquiteto desenvolver argumentos palpáveis ao longo do projeto e as atividades têm dependência uma das outras.

Metodologias que evoluíram da experiência são mais assertivas porque tiveram um tempo de maturação que permitiu ajustar e comprovar seus métodos e técnicas com a prática.

As metodologias que começam com uma visão macro e se aprofundam em uma visão detalhada permitem que o arquiteto tenha uma compreensão holística da arquitetura de informação no início do projeto e depois a esmiúce em cada componente do website. Isso se alinha com um dos princípios necessários para as metodologias de projetos de arquitetura de informação apontados na investigação teórica: ser um processo de design. Como visto, um processo de design possui uma fase de Concepção, na qual se define a visão geral e macro do produto final (no caso o website). Em seguida vem uma fase de Especificação, que detalha e documenta essa visão geral para que possa ser implementada.

Por fim, percebe-se que a concordância dos entrevistados com suas metodologias também ocorre porque elas os ajudam a desenvolver argumentos palpáveis e racionais para justificar seus projetos. Tais argumentos são importante para mitigar os problemas de política interna e facilita a negociação do arquiteto com os demais envolvidos.

As atividades que os entrevistados sentem falta nas suas metodologias são: testes de usabilidade, especialmente as técnicas mais recomendadas para projetos de arquitetura de informação (Card Sorting e protótipos em papel); estudos de cenário; análise de funções; wireframes adequados a páginas muito dinâmicas e interativas (por exemplo, as 
que utilizam tecnologia RIA $^{23}$ ); otimização para mecanismos de busca; preocupação com acessibilidade e preocupação com a ferramenta de publicação do website.

A ausência dos testes de usabilidade corrobora com os resultados do levantamento do perfil do arquiteto de informação apresentado anteriormente, no qual $40 \%$ dos entrevistados responderam que nunca executaram esse tipo de teste.

Os estudos de cenário e a análise de função são atividades características da fase de Concepção. Assim, essa ausência indica que essa fase não é executada completamente.

A falta de adequação dos wireframes a páginas mais dinâmicas e interativas mostra que esse tipo de documento ainda não evoluiu para atender a novas tecnologias de desenvolvimento de interfaces na Web.

A ausência de uma atividade de otimização das páginas do website para mecanismos de busca aponta que o design do sistema de busca tem menos importância que os outros três sistemas que compõem a arquitetura de informação (sistemas de organização, de navegação e de rotulação). Como visto no capítulo 3, esse sistema tem menor interdependência que os demais, o que permite fazer seu design separadamente.

Por fim, a preocupação do arquiteto com a publicação do website mostra que o projeto de arquitetura de informação não se limita a conhecer e definir a interface do usuário. Faz parte do projeto analisar o ambiente interno da empresa e projetar meios para que ela consiga operar adequadamente o website. Esses são os requisitos operacionais que o arquiteto de informação precisa levantar na fase de Pesquisa e atender com seu projeto, como visto na investigação teórica.

Segundo os entrevistados, a maioria dos projetos que conduzem segue todas as etapas das metodologias que apresentaram. As exceções são:

\footnotetext{
${ }^{23}$ RIA, ou Rich Internet Application, é uma forma de utilização do Macromedia Flash, uma linguagem de programação web que permite criar websites com interfaces mais interativas.
} 
- Projetos pequenos: Nesses projetos algumas atividades são fundidas ou eliminadas por não fazerem parte do escopo de trabalho.

- Projetos com solução conhecida: são projetos nos quais existem padrões já definidos para a interface do website, o que elimina parte do trabalho criativo das fases de Concepção e Especificação.

- Projetos que utilizam tecnologia Flash: Projetos com essa tecnologia normalmente não possuem sistema de busca, assim as atividades relacionadas ao design desse sistema são eliminadas.

- Restrição de prazo: nem sempre os projetos dispõem do prazo necessário para que o arquiteto execute todas as atividades que julga necessário.

- Resistência do contratante: o contratante não concorda com alguma das atividades e a elimina do projeto.

Nota-se com essas respostas que as metodologias de projetos de arquitetura de informação precisam ser flexíveis para se adaptarem a projetos com escopo pequeno, e precisam oferecer atalhos suprimindo atividades para economizar tempo. Porém suprimir uma atividade pode comprometer a qualidade do website. Dessa forma é importante que a equipe de projeto e especialmente o contratante avaliem bem os ganhos e perdas da atividade antes de decidir por suprimi-la.

A Tabela 16 detalha as respostas dos entrevistados com relação as metodologias que adotam em seus projetos de arquitetura de informação. 
Tabela 16- Adoção de metodologia nos projetos de arquitetura de informação pelos entrevistados

\begin{tabular}{|c|c|c|c|c|c|}
\hline Categorias de análise & Entrevistado 1 & Entrevistado 2 & Entrevistado 3 & Entrevistado 4 & Entrevistado 5 \\
\hline $\begin{array}{l}\text { Adoção de uma } \\
\text { metodologia nos } \\
\text { projetos de arquitetura } \\
\text { de informação }\end{array}$ & Sim & Sim & Sim & $\operatorname{Sim}$ & Sim \\
\hline $\begin{array}{l}\text { Documentação dos } \\
\text { procedimentos }\end{array}$ & Sim & Sim & Sim & Não & Não \\
\hline $\begin{array}{l}\text { Concordância com a } \\
\text { seqüência das } \\
\text { atividades da } \\
\text { metodologia }\end{array}$ & Sim & Sim & Sim & Sim & Sim \\
\hline $\begin{array}{l}\text { Atividades ausentes na } \\
\text { metodologia }\end{array}$ & $\begin{array}{l}\text { - Teste de } \\
\text { usabilidade } \\
\text { - Estudos de } \\
\text { cenário }\end{array}$ & $\begin{array}{l}\text { - Card Sorting } \\
\text { - Paper Prototype } \\
\text { - Wireframes } \\
\text { adequados para } \\
\text { tecnologia RIA }\end{array}$ & - Paper Prototype & $\begin{array}{l}\text { - Otimização para } \\
\text { mecanismo de } \\
\text { busca } \\
\text { - Preocupação com } \\
\text { Acessibilidade } \\
\text { - Preocupação com } \\
\text { a ferramenta de } \\
\text { publicação do } \\
\text { website }\end{array}$ & $\begin{array}{l}\text { - Análise das } \\
\text { funções }\end{array}$ \\
\hline $\begin{array}{l}\text { Motivos para alguns } \\
\text { projetos não seguirem } \\
\text { todas as atividades da } \\
\text { metodologia }\end{array}$ & $\begin{array}{l}\text { - Projetos } \\
\text { pequenos } \\
\text { - Projetos com } \\
\text { solução conhecida }\end{array}$ & \begin{tabular}{|l|} 
- Projetos \\
pequenos \\
- Projetos em Flash
\end{tabular} & $\begin{array}{l}\text { - Projetos } \\
\text { pequenos } \\
\text { - Projetos com } \\
\text { solução conhecida }\end{array}$ & - Projetos pequenos & $\begin{array}{l}\text { - Restrição de } \\
\text { prazo } \\
\text { - Resistência do } \\
\text { contratante }\end{array}$ \\
\hline
\end{tabular}

\subsubsection{Análise das fases do quadro de referência na metodologia dos entrevistados}

$\mathrm{Na}$ fase I da pesquisa, todos os entrevistados foram convidados a desenhar suas metodologias utilizando cartões post-it para representar as atividades e a sequiência delas. $\mathrm{Na}$ fase III, os entrevistados compararam suas metodologias com o quadro de referência proposto na investigação teórica, identificando cada atividade nas fases desse quadro.

A seguir estão apresentados os desenhos das metodologias de cada entrevistado com suas atividades identificadas nas cinco fases do quadro de referência. 
Figura 9 - Metodologia de projetos de arquitetura de informação do entrevistado 1

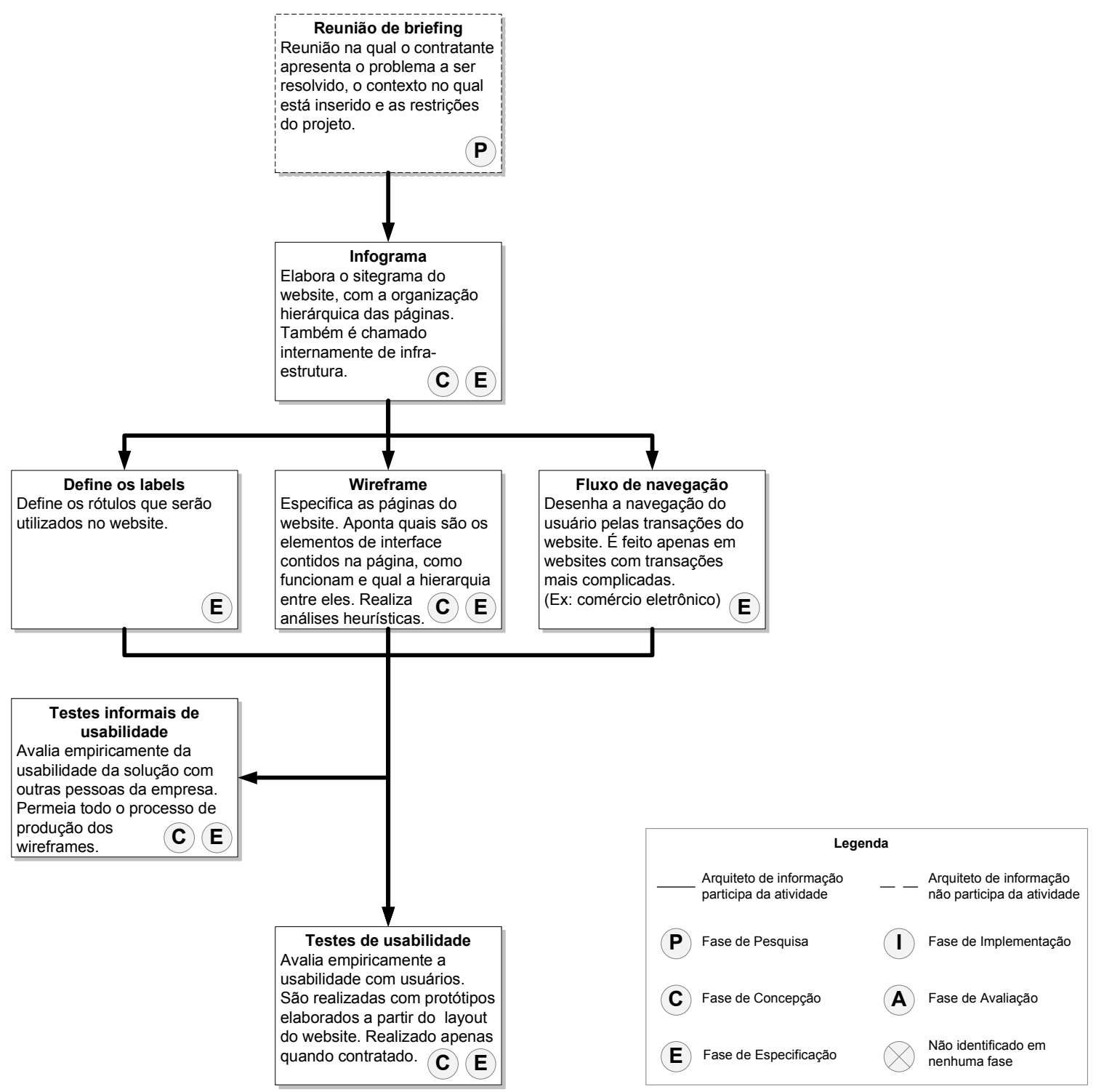


Figura 10 - Metodologia de projetos de arquitetura de informação do entrevistado 2

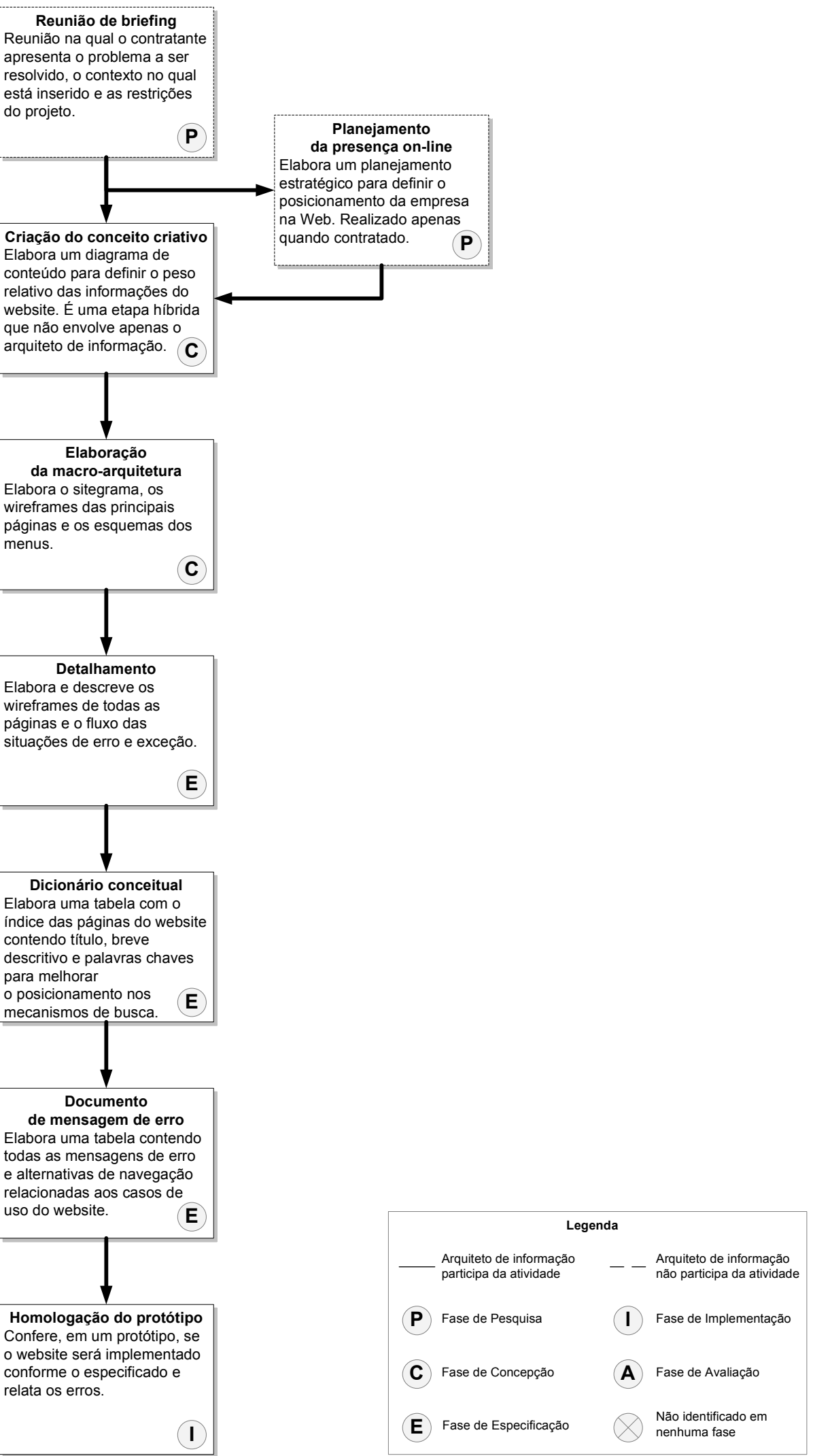


Figura 11 - Metodologia de projetos de arquitetura de informação do entrevistado 3

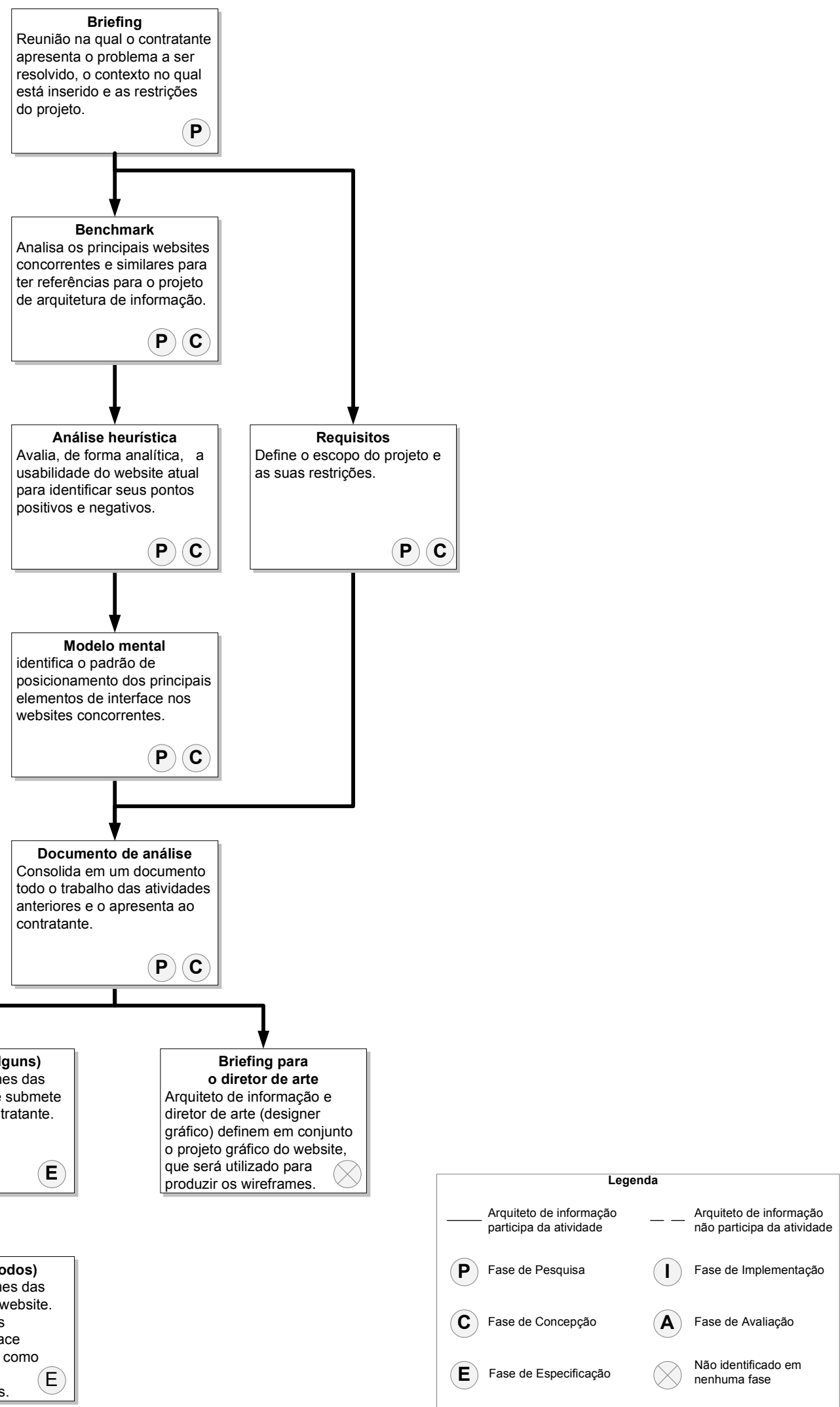


Figura 12 - Metodologia de projetos de arquitetura de informação do entrevistado 4

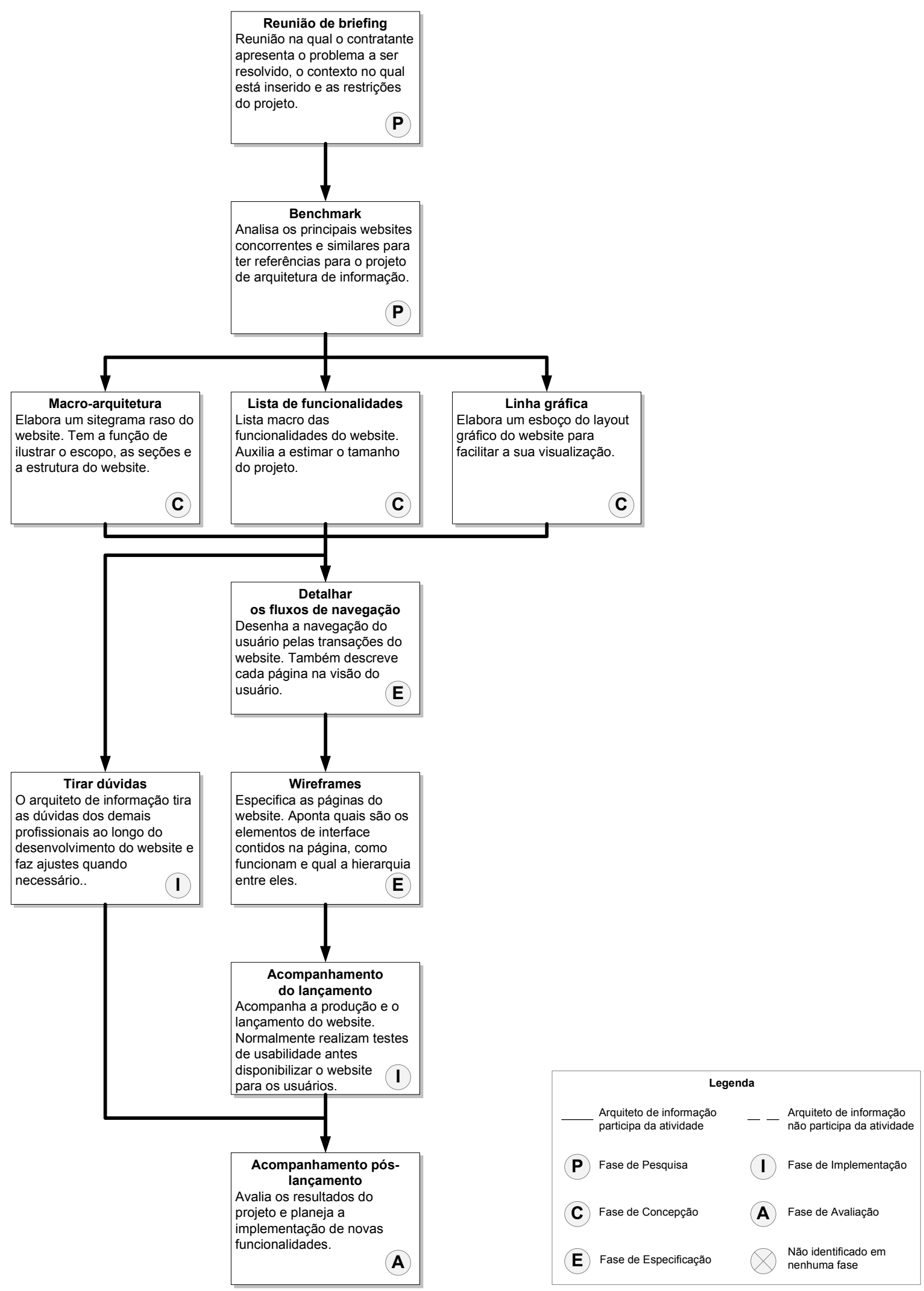


Figura 13 - Metodologia de projetos de arquitetura de informação do entrevistado 5

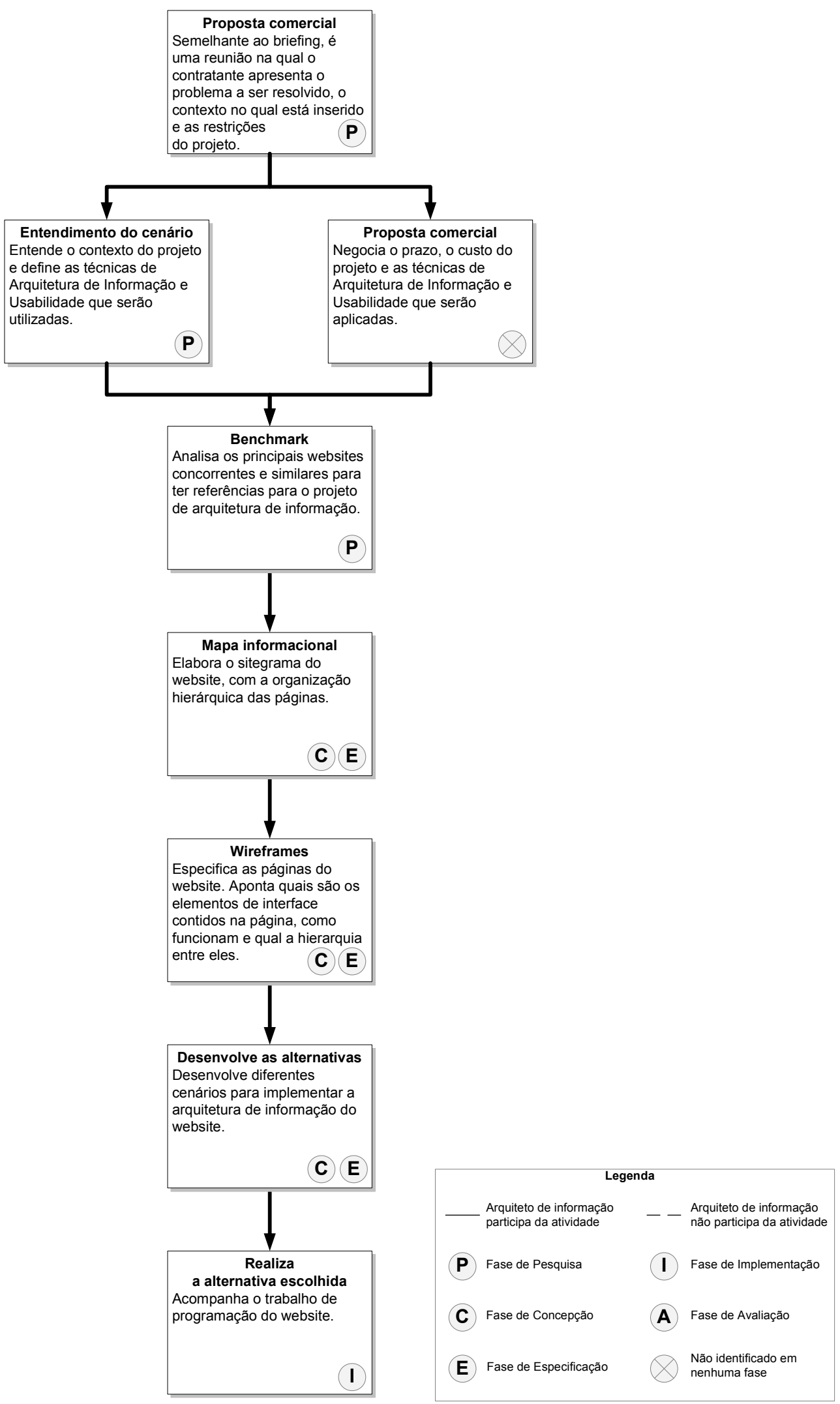


A seguir as metodologias dos entrevistados são analisadas segundo as fases do quadro de referência.

\subsection{Análise da fase de Pesquisa na metodologia dos entrevistados}

Conforme o quadro de referência, a fase de Pesquisa na metodologia de projetos de arquitetura de informação é destinada a pesquisar e compreender a empresa contratante e os usuários do website. Nessa fase é definido o escopo e os requisitos do projeto.

Todos os entrevistados declararam que possuem uma fase de Pesquisa nas suas metodologias de projeto de arquitetura de informação e identificaram atividades que correspondem a essa fase. A maioria dos entrevistados inicia a fase de Pesquisa com uma atividade chamada "Reunião de Briefing", na qual o contratante apresenta o problema a ser resolvido, o contexto no qual está inserido e as suas restrições. Após essa reunião, a maioria dos entrevistados realiza uma atividade chamada "Benchmark", que tem a função de avaliar websites concorrentes e semelhantes.

Os entrevistados citaram que normalmente participam da fase de Pesquisa nos seus projetos, que é realizada com trabalho em equipe envolvendo profissionais das áreas de atendimento, criação, tecnologia da informação, projeto gráfico e gerência de produto. Apenas o entrevistado 1 declarou que não participa dessa fase e se limita a compreender as informações que os outros profissionais levantaram na reunião de briefing com o contratante.

A principal variável pesquisada nessa fase, segundo os entrevistados, são as áreas internas da empresa e suas necessidades. As outras variáveis são as empresas concorrentes e o perfil do usuário.

Segundo os entrevistados, as técnicas de pesquisa mais utilizadas são o benchmark com websites concorrentes e similares e as reuniões exploratórias (entrevistas) com os funcionários da empresa contratante. Também foi citado o uso, nessa fase, da análise heurística para diagnosticar os problemas no website do contratante e dos concorrentes. Apenas o entrevistado 4 citou o uso de pesquisas de focus group com usuários para 
levantar o perfil deles. No caso dos demais entrevistados a pesquisa do perfil do usuário é realizada com relatórios internos e entrevistas com os funcionários da empresa contratante.

A principal fonte de informação nessa fase citada pelos entrevistados são os funcionários que representam a empresa contratante. Outras fontes de informação são: websites de empresas concorrentes ao contratante, o próprio website do contratante e os usuários do website. Apenas o entrevistado 4 respondeu que nessa fase realiza pesquisas diretas com usuários (focus group). Esse entrevistado desenvolve websites apenas para a empresa onde trabalha, não possui uma empresa contratante externa.

Por fim, três dos entrevistados declararam que as informações obtidas na fase de Pesquisa são superficiais, especialmente as que se referem aos usuários Dos dois entrevistados que declararam que a qualidade das informações obtidas é adequada, um deles, o entrevistado 4, faz pesquisas diretas com o usuário. O outro, o entrevistado 3, atua predominantemente no desenvolvimento de websites para o mercado financeiro, que é altamente competitivo e regulamentado. Por isso a pesquisa de benchmark lhe é uma técnica bastante rica em informações.

O que se observa com as respostas dos entrevistados é que a abordagem de Design Centrado no Usuário da Ciência da Informação, não são utilizadas na fase de Pesquisa, confirmando a investigação teórica. Os entrevistados se concentram na análise da empresa contratante e dos seus concorrentes, e não realizam pesquisas diretas com o usuário, indo contra os princípios dessa abordagem. Isso pode justificar a qualidade superficial das informações obtidas.

A Tabela 17 apresenta as respostas dos entrevistados sobre a fase de Pesquisa. 
Tabela 17 - Análise da fase de Pesquisa nas metodologias dos entrevistados

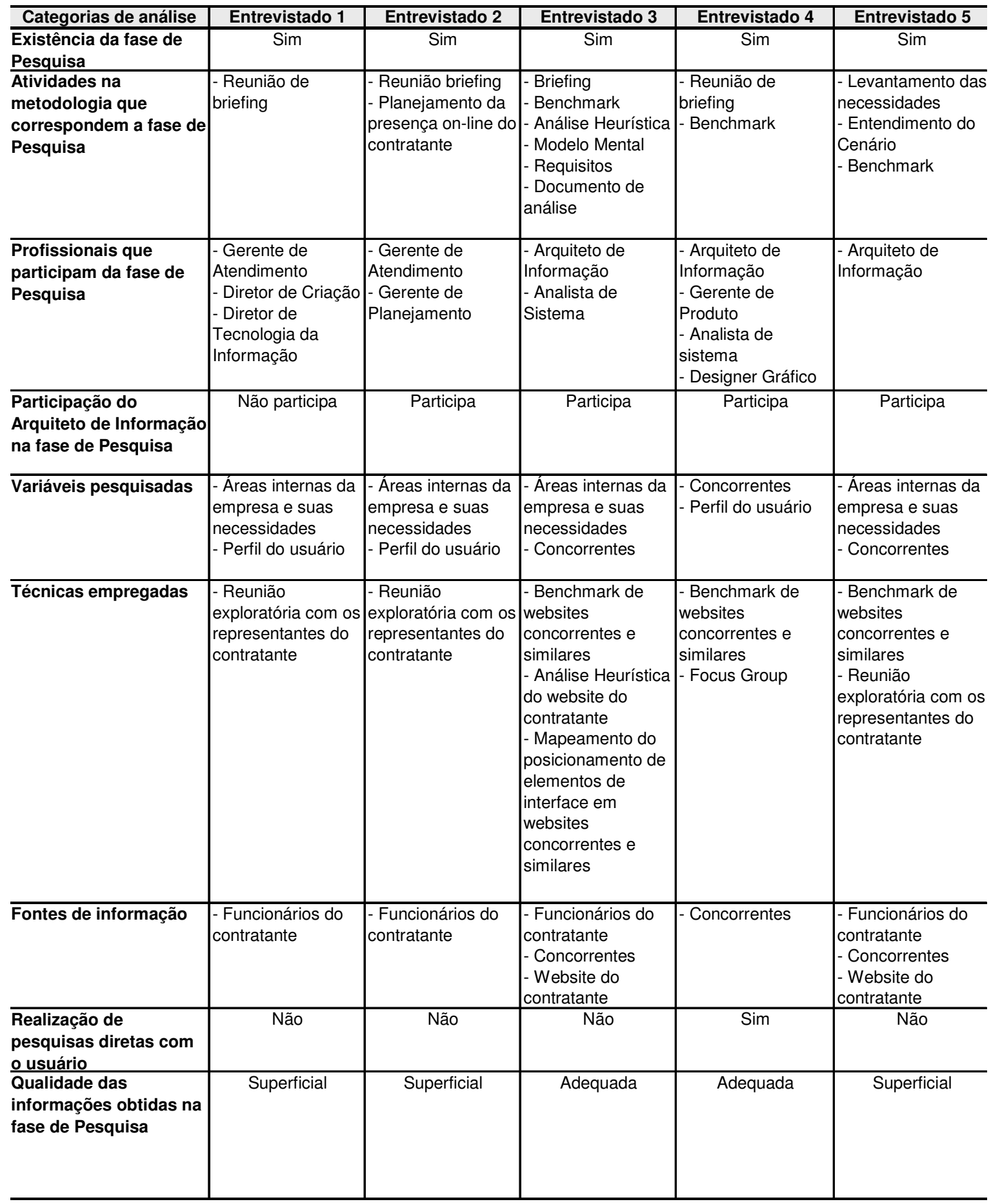




\subsection{Análise da fase de Concepção na metodologia dos entrevistados}

A fase de Concepção, como visto na investigação teórica, é a fase mais criativa da metodologia. Nela são definidas as linhas gerais da solução e as regras dos sistemas de organização, de navegação, de rotulação e de busca.

Todos os entrevistados declararam possuir uma fase de Concepção nas suas metodologias de projetos de arquitetura de informação e apontaram as atividades que a compõem. Não existe uma uniformidade nos nomes dessas atividades porque cada entrevistado adota nomes diferentes, que normalmente correspondem aos nomes dos documentos produzidos.

No caso específico do entrevistado 3, não foi possível identificar atividades exclusivas da fase de Concepção, fazendo com que essa fase se misture com a fase de Pesquisa na sua metodologia. Ao se misturar essas duas fases, o arquiteto de informação pode conceber idéias que não atendem a todos os requisitos do projeto porque as concebeu antes definir completa e detalhadamente o problema a ser resolvido. Para minimizar isso, o entrevistado 3 possui uma atividade chamada "Documento de Analise", na qual consolida todo o trabalho das atividades anteriores e ajuda a encontrar inconsistências.

Diferente da fase de Pesquisa, todos os entrevistados declararam que participam da fase de Concepção. Porém eles contam com a ajuda do profissionais das áreas de Projeto Gráfico e Tecnologia da Informação, que contribuem com sugestões para o projeto e validam se as idéias concebidas são factíveis de implementação

As técnicas utilizadas nessa fase citadas pelos entrevistados são: esboço do sitegrama, esboço de conteúdo, diagrama de conteúdo, benchmark, análise heurística, mapeamento do posicionamento de elementos de interface em websites concorrentes e similares, levantamento das funcionalidades e esboço da linha gráfica.

O benchmark, o mapeamento do posicionamento dos elementos de interface e o levantamento das funcionalidades não são técnicas destinadas à geração de idéias, objetivo da fase de Concepção. São técnicas destinadas ao levantamento de informações, 
característico da fase de Pesquisa. Isso mostra que outros entrevistados também não separam claramente essas duas fases nas suas metodologias.

Por fim, três dos cinco entrevistados declararam que documentam os conceitos desenvolvidos nessa fase. Essa documentação serve para registrar os conceitos que determinaram o modelo mental do website e as regras dos quatro sistemas que compõem a arquitetura de informação com o intuito de perpetuá-los nas manutenções futuras. BUSTAMANTE (2004) menciona a importância de documentar os conceitos definidos na fase de Concepção para melhorar a comunicação e alinhar a equipe do projeto.

A realização de testes de usabilidade ao longo do projeto é um dos princípios do Design Centrado no Usuário na abordagem da Interação Humano-Computador, como visto na investigação teórica. Dessa forma essa pesquisa procurou avaliar a frequiência com que esses testes são realizados.

Pelas respostas, são poucos os projetos onde são realizados testes de usabilidade. $\mathrm{O}$ principal motivo citado é que os entrevistados não conseguem convencer seus contratantes da importância desses testes. Os outros motivos para não realizar testes de usabilidade são: falta de estrutura em suas empresas para executá-los e projetos de porte pequeno. Apenas o entrevistado 4 declarou que possui na sua empresa uma estrutura própria para realizar testes de usabilidade, contando inclusive com um laboratório específico para isso.

A realização de testes de usabilidade aumenta o custo e o prazo do projeto de arquitetura de informação. Porém, como cita MARCUS (2002), a realização desses testes reduz os custos e o prazo de desenvolvimento do website como um todo e também reduz seus custos de manutenção e redesign. Porém os contratantes dos entrevistados ainda não conhecem essas vantagens. Citando as palavras do Entrevistado 2, "as pessoas preferem errar e consertar a testar antes de colocar no ar. É padrão oferecer os testes de usabilidade e os clientes [contratantes] recusarem."

As técnicas de testes de usabilidade mais indicadas para a Arquitetura de Informação, o Card Sorting e os testes com protótipos em papel, são pouco utilizadas. Alguns dos motivos para isso são semelhantes aos motivos para não realizar testes de usabilidade: falta de prazo nos projetos e não conseguir convencer o contratante da sua 
importância. Outros motivos são: falta de domínio das técnicas, falta de confiança na técnica de protótipos em papel e não enxergar a necessidade de aplicar a técnica.

A falta de domínio das técnicas demonstra que elas ainda não estão completamente difundidas entre os profissionais, indicando ineficiências na formação autodidata.

Já falta de confiança na técnica dos protótipos em papel, citada pelo entrevistado 4, ocorre porque ele acredita que o usuário precisa ter uma capacidade de abstração muito grande para que os testes com protótipos de papel sejam efetivos. De fato essa é uma restrição característica da técnica, mas, segundo SNYDER (2003), isso é superado ao se convocar para realizar esse teste usuários com maior fluência no uso de computadores e da Internet.

O entrevistado 3 declarou que não enxerga a necessidade de aplicar a técnica de Card Sorting porque a fase de Pesquisa já lhe proveu informação suficiente para definir o sistema de organização e de rotulação do website. Vale lembrar que esse entrevistado atua predominantemente em projetos do mercado financeiro, no qual muitos rótulos são definidos em normas regulatórias.

A Tabela 18 detalha as respostas dos entrevistados referentes à fase de Concepção. 
Tabela 18- Análise da fase de Concepção nas metodologia dos entrevistados

\begin{tabular}{|c|c|c|c|c|c|}
\hline Categorias de análise & Entrevistado 1 & Entrevistado 2 & Entrevistado 3 & Entrevistado 4 & Entrevistado 5 \\
\hline $\begin{array}{l}\text { Existência da fase de } \\
\text { Concepcão }\end{array}$ & $\operatorname{Sim}$ & $\operatorname{Sim}$ & Sim & Sim & Sim \\
\hline $\begin{array}{l}\text { Atividades na } \\
\text { metodologia que } \\
\text { correspondem a fase de } \\
\text { Concepção }\end{array}$ & $\begin{array}{l}\text { - Infograma } \\
\text { - Wireframes } \\
\text { - Testes de } \\
\text { usabilidade } \\
\text { informais } \\
\text { - Testes de } \\
\text { usabilidade }\end{array}$ & $\begin{array}{l}\text { - Criação do } \\
\text { conceito criativo } \\
\text { - Elaboração da } \\
\text { Macro-arquitetura }\end{array}$ & $\begin{array}{l}\text { Não é definida. Se } \\
\text { mistura com a fase } \\
\text { de Pesquisa }\end{array}$ & $\begin{array}{l}\text { - Macro-Arquitetura } \\
\text { - Lista de } \\
\text { Funcionalidades } \\
\text { - Linha Gráfica }\end{array}$ & $\begin{array}{l}\text { - Mapa } \\
\text { informacional } \\
\text { - Wireframe } \\
\text { - Desenvolvimento } \\
\text { de alternativas }\end{array}$ \\
\hline $\begin{array}{l}\text { Profissionais que } \\
\text { participam da fase de } \\
\text { Concepção }\end{array}$ & $\begin{array}{l}\text { - Arquiteto de } \\
\text { informação }\end{array}$ & $\begin{array}{l}\text { - Arquiteto de } \\
\text { informação } \\
\text {-Designer gráfico }\end{array}$ & $\begin{array}{l}\text { - Arquiteto de } \\
\text { Informação } \\
\text { - Analista de } \\
\text { Sistema }\end{array}$ & $\begin{array}{l}\text { - Arquiteto de } \\
\text { Informação } \\
\text { - Analista de } \\
\text { sistema } \\
\text { - Designer gráfico }\end{array}$ & $\begin{array}{l}\text { - Arquiteto de } \\
\text { Informação }\end{array}$ \\
\hline $\begin{array}{l}\text { Motivos para não } \\
\text { aplicar testes de } \\
\text { usabilidade nos } \\
\text { projetos }\end{array}$ & $\begin{array}{l}\text { - Não conseguem } \\
\text { convencer o } \\
\text { contratante da } \\
\text { importância. }\end{array}$ & $\begin{array}{l}\text { - Não conseguem } \\
\text { convencer o } \\
\text { contratante da } \\
\text { importância. }\end{array}$ & \begin{tabular}{|l|} 
- Não possui \\
estrutura para fazer \\
testes de \\
usabilidade.
\end{tabular} & $\begin{array}{l}\text { - Testes de } \\
\text { usabilidade são } \\
\text { feitos apenas para } \\
\text { projetos grandes. }\end{array}$ & $\begin{array}{l}\text { Não respondeu a } \\
\text { questão. }\end{array}$ \\
\hline $\begin{array}{l}\text { Freqüência de } \\
\text { aplicação de testes de } \\
\text { Card Sorting nos } \\
\text { projetos }\end{array}$ & Não & Não & Não & As vezes & As vezes \\
\hline $\begin{array}{l}\text { Motivos para não } \\
\text { aplicar testes de Card } \\
\text { Sorting }\end{array}$ & $\begin{array}{l}\text { - Nâo domina a } \\
\text { técnica }\end{array}$ & $\begin{array}{l}\text { - Falta prazo nos } \\
\text { projetos }\end{array}$ & $\begin{array}{l}\text { - Não enxerga a } \\
\text { necessidade de } \\
\text { aplicar a técnica } \\
\text { porque se sente } \\
\text { seguro com a } \\
\text { metodologia que } \\
\text { possui }\end{array}$ & Não cita & Não cita \\
\hline $\begin{array}{l}\text { Freqüência de } \\
\text { aplicação de testes com } \\
\text { Protótipos de Papel nos } \\
\text { projetos }\end{array}$ & Não & Não & Não & Não & Raramente \\
\hline $\begin{array}{l}\text { Motivos para não } \\
\text { aplicar testes com } \\
\text { Protótipos de Papel }\end{array}$ & $\begin{array}{l}\text { - Nâo domina a } \\
\text { técnica }\end{array}$ & $\begin{array}{l}\text { - Falta prazo nos } \\
\text { projetos } \\
\text { - Não conseguem } \\
\text { convencer o } \\
\text { contratante da } \\
\text { importância. }\end{array}$ & Não cita & $\begin{array}{l}\text { - Não confia na } \\
\text { técnica }\end{array}$ & Não cita \\
\hline
\end{tabular}




\subsection{Análise da fase de Especificação na metodologia dos entrevistados}

A fase de Especificação é o momento na metodologia no qual se detalha e se documenta como o website deve ser implementado, como visto na investigação teórica. É nessa fase que são produzidos os documentos de especificação da arquitetura de informação do website: o sitegrama, o fluxo de navegação, os wireframes e o vocabulário controlado.

A fase de Especificação também está presente na metodologia de todos os entrevistados, que apontaram atividades específicas para essa fase. Não existe muita uniformidade no nomes das atividades que compõem essa fase nas metodologias dos entrevistados, com exceção da atividade "Wireframe", citada por três entrevistados.

Observa-se, na metodologia dos entrevistados 1 e 5 que a fase de Especificação se mistura com a fase de Concepção. De fato, a fase de Especificação tem a função de detalhar e documentar os conceitos definidos na fase anterior, o que pode causar essa mistura. Porém, a fase de Especificação normalmente demanda a elaboração de um volume grande de documentos. Se os conceitos e as regras dos quatro sistemas componentes da arquitetura de informação não estiverem bem definidos antes de iniciar a fase de Especificação, as mudanças podem implicar em uma grande carga de trabalho para realizar revisões.

O principal ator na fase de Especificação é o arquiteto de informação, responsável por produzir todos os documentos. Porém, os entrevistados citam que os profissionais que participaram da fase anterior continuam a participar dessa fase com as mesmas funções.

Os tipos de documentos produzidos nessa fase citados pelos entrevistados são os mesmos tipos apontados na investigação teórica: os wireframes, o sitegrama e o fluxo de navegação. Não foi citado o vocabulário controlado. O entrevistado 2 citou que produz nessa fase um tipo de documento específico chamado dicionário conceitual que se trata de um índice de todas as páginas do website com título, breve descritivo e palavras chaves. Sua função é definir as metatags da página para os mecanismos de busca. 
Todos os entrevistados também declararam que possuem templates para todos os tipos de documentos produzidos nessa fase. Ter esses templates é esperado uma vez que a fase de Especificação é a fase que normalmente consome a maior quantidade de horas no projeto e tais templates ajudam a aumentar a produtividade.

$\mathrm{Na}$ Tabela 19 estão as respostas dos entrevistados referentes à fase de Especificação.

Tabela 19 - Análise da fase de Especificação nas metodologias dos entrevistados

\begin{tabular}{|c|c|c|c|c|c|}
\hline Categorias de análise & Entrevistado 1 & Entrevistado 2 & Entrevistado 3 & Entrevistado 4 & Entrevistado 5 \\
\hline $\begin{array}{l}\text { Existência da fase de } \\
\text { Especificação }\end{array}$ & Sim & Sim & Sim & Sim & Sim \\
\hline $\begin{array}{l}\text { Atividades na } \\
\text { metodologia que } \\
\text { correspondem a fase de } \\
\text { Especificação }\end{array}$ & \begin{tabular}{|l|} 
- Infograma \\
- Wireframe \\
- Fluxo de \\
navegação \\
- Define os labels \\
- Testes de \\
usabilidade \\
informais \\
- Testes de \\
usabilidade \\
Se mistura com a \\
fase de Concepção
\end{tabular} & $\begin{array}{l}\text { - Detalhamento } \\
\text { - Dicionário } \\
\text { Conceitual } \\
\text { - Documento de } \\
\text { mensagens de erro } \\
\end{array}$ & - Wireframes & $\begin{array}{l}\text { - Detalhar os fluxos } \\
\text { de navegação } \\
\text { - Wireframes }\end{array}$ & $\begin{array}{l}\text { Não é definida. Se } \\
\text { mistura com a fase } \\
\text { de Concepção. }\end{array}$ \\
\hline $\begin{array}{l}\text { Profissionais que } \\
\text { participam da fase de } \\
\text { Especificação }\end{array}$ & $\begin{array}{l}- \text { Arquiteto de } \\
\text { informação } \\
\text { - Analista de } \\
\text { Sistema } \\
\end{array}$ & $\begin{array}{l}\text { - Arquiteto de } \\
\text { informação } \\
\text { - Designer Gráfico }\end{array}$ & $\begin{array}{l}\text { Arquiteto de } \\
\text { informação }\end{array}$ & $\begin{array}{l}- \text { Arquiteto de } \\
\text { informação } \\
\text { - Analista de } \\
\text { Sistema } \\
\end{array}$ & $\begin{array}{l}\text { Arquiteto de } \\
\text { informação }\end{array}$ \\
\hline $\begin{array}{l}\text { Documentos } \\
\text { produzidos }\end{array}$ & \begin{tabular}{|l|} 
- Sitegrama \\
(infograma) \\
- Wireframes \\
- Fluxo de \\
navegação (apenas \\
para websites com \\
transações \\
complicadas)
\end{tabular} & \begin{tabular}{|l} 
- Sitegrama \\
- Wireframes \\
- Fluxo de \\
navegação \\
- Dicionário \\
conceitual \\
\end{tabular} & \begin{tabular}{|l} 
- Sitegrama \\
- Wireframes \\
- Fluxo de \\
navegação
\end{tabular} & $\begin{array}{l}\text { - Fluxo de } \\
\text { navegação } \\
\text { - Wireframes }\end{array}$ & $\begin{array}{l}- \text { Sitegrama } \\
\text { - Wireframes }\end{array}$ \\
\hline $\begin{array}{l}\text { Existência de templates } \\
\text { dos documentos }\end{array}$ & Sim & Sim & Sim & Sim & Sim \\
\hline
\end{tabular}

\subsection{Análise da fase de Implementação na metodologia dos entrevistados}

A fase de Implementação, conforme visto na investigação teórica, cuida do acompanhamento do trabalho das demais equipes envolvidas no projeto e responsáveis por implementar o website. Nessa fase o arquiteto acompanha o trabalho desses profissionais para apresentar seus documentos de especificação, responder a dúvidas, validar se o website foi implementado conforme sua especificação e revisar sua documentação caso necessário. 
Dos cinco profissionais entrevistados, três citaram que possuem uma fase de Implementação nas suas metodologias. Esses entrevistados identificaram as atividades que correspondem a fase, nas quais não foi observada uniformidade nos nomes. Os dois entrevistados que não identificaram atividades em suas metodologias que correspondam a fase de Implementação declararam que executam a fase de maneira informal por meio de acompanhamentos parciais e sob demanda.

Segundo os entrevistados, as áreas cujo trabalho é acompanhado pelo arquiteto de informação são as mesmas que participaram das fases anteriores: projeto gráfico e tecnologia da informação.

Nota-se, nas respostas dos entrevistados, que existe pouca preocupação com a fase de Implementação nas suas metodologias, confirmando a investigação teórica.

A Tabela 20 apresenta as respostas dos entrevistados sobre a fase de Implementação.

Tabela 20 - Análise da fase de Implementação nas metodologias dos entrevistados

\begin{tabular}{l|l|l|l|l|c}
\hline \multicolumn{1}{c|}{ Categorias de análise } & Entrevistado 1 & Entrevistado 2 & Entrevistado 3 & Entrevistado 4 & Entrevistado 5 \\
\hline $\begin{array}{l}\text { Existência da fase de } \\
\text { Implementação }\end{array}$ & Não & Sim & Não & Sim \\
\hline $\begin{array}{l}\text { Atividades na } \\
\text { metodologia que } \\
\text { correspondem a fase de } \\
\text { Implementação }\end{array}$ & --- & $\begin{array}{l}\text { - Homologação do } \\
\text { protótipo }\end{array}$ & --- & $\begin{array}{l}\text { - Tirar dúvidas } \\
\text { - Acompanhamento } \\
\text { do lançamento }\end{array}$ & $\begin{array}{l}\text { - Realternativa a } \\
\text { escolhida }\end{array}$ \\
\hline $\begin{array}{l}\text { Profissionais que } \\
\text { participam da fase de } \\
\text { Implementação }\end{array}$ & $\begin{array}{l}\text { - Arquiteto de } \\
\text { Informação } \\
- \text { Analista de } \\
\text { Sistema } \\
\text { - Designer Gráfico }\end{array}$ & $\begin{array}{l}\text { - Arquiteto de } \\
\text { Informação } \\
\text { - Analista de } \\
\text { Sistema }\end{array}$ & $\begin{array}{l}\text { - Arquiteto de } \\
\text { Informação } \\
\text { - Analista de } \\
\text { Sistema } \\
\text { - Designer Gráfico }\end{array}$ & $\begin{array}{l}\text { Informação } \\
\text { - Analista de } \\
\text { Sistema }\end{array}$ & --- \\
\hline
\end{tabular}

\subsection{Análise da fase de Avaliação na metodologia dos entrevistados}

A fase de Avaliação cuida da avaliação dos resultados do projeto, conforme o quadro de referência visto na investigação teórica. Nessa fase é avaliado se o website atingiu os objetivos planejados para que os profissionais envolvidos tenham a possibilidade de aprender com os próprios erros e melhorar sua forma de trabalho.

Essa fase é a menos citada pelos entrevistados. Quatro dos entrevistados declararam que não fazem avaliação dos resultados dos seus projetos. "Larga o filho no 
mundo quando o site vai para o ar", citou o entrevistado 1 para ilustrar a ausência dessa fase na sua metodologia. Esse resultado confirma a investigação teórica, na qual se observou que os autores dedicam pouca atenção à fase de Avaliação.

Apenas o entrevistado 4 declarou ter essa fase na sua metodologia e apontou uma única atividade que lhe corresponde. Esse entrevistado, ao contrário dos demais, trabalha em uma empresa que desenvolve seus próprios websites, o que lhe facilita o acesso a informações para avaliar os resultados dos seus projetos.

O entrevistado 3 citou que a avaliação dos projetos fica a cargo da empresa contratante e ele só têm acesso a essa avaliação caso a empresa resolva espontaneamente apresentá-la. $\mathrm{O}$ entrevistado 2 citou que a empresa onde trabalha realiza avaliações dos resultados dos projetos, mas isso é feito por outra área e apenas quando o contratante solicita esse serviço. Não foi observada nenhuma atitude pró-ativa nos entrevistados para efetuar uma avaliação dos seus projetos independente da vontade de seus contratantes.

A Tabela 21 mostra as respostas dos entrevistados referentes à fase de Avaliação.

Tabela 21 - Análise da fase de Avaliação nas metodologias dos entrevistados

\begin{tabular}{l|c|c|c|c|c}
\hline Categorias de análise & Entrevistado 1 & Entrevistado 2 & Entrevistado 3 & Entrevistado 4 & Entrevistado 5 \\
\hline $\begin{array}{l}\text { Existência da fase de } \\
\text { Avaliação }\end{array}$ & Não & Não & Não & Sim & Não \\
\hline $\begin{array}{l}\text { Atividades na } \\
\text { metodologia que } \\
\text { correspondem a fase de } \\
\text { Avaliação }\end{array}$ & --- & -- & -- & $\begin{array}{l}\text { - Acompanhamento } \\
\text { pós-lançamento }\end{array}$ & --- \\
\hline $\begin{array}{l}\text { Motivos para a não } \\
\text { existência da fase }\end{array}$ & Não cita & $\begin{array}{l}\text { - A avaliação é feita } \\
\text { por outro } \\
\text { departamento da } \\
\text { empresa e apenas } \\
\text { quando contratado. } \\
\text { avaliação. }\end{array}$ & & & Não cita \\
\hline
\end{tabular}

\subsubsection{Análise das dificuldades dos entrevistados nos projetos de arquitetura de informação}

$\mathrm{Na}$ fase II da entrevista foi solicitado a cada entrevistado que escolhesse um projeto de arquitetura de informação do qual participou e citasse as três principais dificuldades que enfrentou durante esse projeto. Nem todos os entrevistados conseguiram 
citar três dificuldades, assim, foram levantadas 13 citações, classificadas em 9 dificuldades diferentes.

A dificuldade mais citada foi integrar o website com sistemas legados. Em seguida foram mais citadas: evitar usar no website a linguagem e a organização interna da empresa contratante e fazer o contratante compreender os documentos de especificação. A Tabela 22 apresenta essas dificuldades.

Tabela 22 - Dificuldades dos entrevistados nos projetos de arquitetura de informação

\begin{tabular}{l|c}
\hline \multicolumn{1}{c|}{ Dificuldade } & Qtd citações \\
\hline $\begin{array}{l}\text { Integrar o website com sistemas legados } \\
\text { Evitar usar no website a linguagem e a organização interna da } \\
\text { empresa contratante }\end{array}$ & 2 \\
\hline $\begin{array}{l}\text { Fazer o contratante compreender os documentos de } \\
\text { especificação }\end{array}$ & 2 \\
\hline Atender vários decisores & 1 \\
\hline Atender públicos-alvos diferentes & 1 \\
\hline Definir o objetivo do site & 1 \\
\hline Gerenciar um volume grande de documentos & 1 \\
\hline Obter acesso as fontes de informação & 1 \\
\hline $\begin{array}{l}\text { Produzir um documento conciso e expor os pontos negativos } \\
\text { do website do contratante sem gerar antipatias }\end{array}$ & 1 \\
\hline Total geral & 13 \\
\hline
\end{tabular}

Foi realizada uma análise das dificuldades quanto ao foco das questões apresentadas pelos entrevistados, isto é, a identificação do núcleo central do problema segundo suas próprias óticas. Nessa análise foram identificados três focos diferentes:

- Contratante: ocorre quando o foco recai em alguma habilidade essencial, característica ou requisito do contratante do projeto. Esse foi o foco com mais citações e contém quatro dificuldades diferentes.

- Próprio ao trabalho de Arquitetura de Informação: ocorre quando o foco recai sobre alguma habilidade essencial, ferramenta necessária ou nas condições de trabalho do entrevistado. Esse foi o segundo foco com mais citações também com quatro dificuldades diferentes. 
- Contexto tecnológico: ocorre quando o foco recai nos requisitos técnicos do projeto. Esse foi o foco com menos citações e contém uma dificuldade, porém a mais citada na pesquisa.

Percebe-se nessa análise que o contratante é um forte ponto de dificuldade nos projetos de arquitetura de informação. A Tabela 23 mostra as dificuldades classificadas pelo foco das suas questões.

\begin{tabular}{l|l|c}
\multicolumn{3}{l}{ Tabela 23 - Classificação das dificuldades pelo foco das questões dos entrevistados } \\
\hline Foco da questão & \multicolumn{1}{|c}{ Dificuldade } & Qtd citações \\
\hline Contratante & $\begin{array}{l}\text { Evitar usar no website a linguagem e a organização } \\
\text { interna da empresa contratante }\end{array}$ & 2 \\
\cline { 2 - 3 } & $\begin{array}{l}\text { Fazer o contratante compreender os documentos de } \\
\text { especificação }\end{array}$ & 2 \\
\cline { 2 - 3 } & Atender vários decisores & 1 \\
\cline { 2 - 3 } & Definir o objetivo do site & 1 \\
\hline $\begin{array}{l}\text { Próprio ao trabalho } \\
\text { de Arquitetura de } \\
\text { Informação }\end{array}$ & Atender públicos-alvos diferentes & 1 \\
\cline { 2 - 3 } & Gerenciar um volume grande de documentos & 1 \\
\cline { 2 - 3 } & Obter acesso as fontes de informação & 1 \\
\cline { 2 - 3 } & $\begin{array}{l}\text { Produzir um documento conciso e expor os pontos } \\
\text { negativos do website do contratante sem gerar antipatias }\end{array}$ & 13 \\
\hline $\begin{array}{l}\text { Contexto } \\
\text { tecnológico }\end{array}$ & Integrar o website com sistemas legados & 3 \\
\hline Total geral & & 13 \\
\hline
\end{tabular}

Ao descrever suas dificuldades, os entrevistados indicaram em quais atividades das suas metodologias elas ocorreram e com isso foi possível classificá-las nas fases do quadro de referência.

A fase de Concepção é a que apresenta mais dificuldades diferentes e também a dificuldade mais citada. Polêmicas naturalmente surgem na fase de Concepção porque é nela que se decide a solução do projeto, portanto é compreensível que apareçam mais dificuldades.

A fases de Pesquisa apresentou mais dificuldades diferentes que a fase de Especificação, mas ambas apresentam a mesma quantidade de citações. Não foram citadas dificuldades nas fases de Implementação e Avaliação, o que demonstra a baixa preocupação dos entrevistados com essas fases. A Tabela 24 mostra a classificação das dificuldades nas fases do quadro de referência. 
Tabela 24 - Classificação das dificuldades nas fases do quadro de referência

\begin{tabular}{|c|c|c|}
\hline Fase & Dificuldade & Qtd citações \\
\hline \multirow[t]{3}{*}{ Pesquisa } & Definir o objetivo do site & 1 \\
\hline & Obter acesso as fontes de informação & 1 \\
\hline & $\begin{array}{l}\text { Produzir um documento conciso e expor os pontos negativos } \\
\text { do website do contratante sem gerar antipatias }\end{array}$ & 1 \\
\hline \multirow[t]{4}{*}{ Concepção } & Integrar o website com sistemas legados & 3 \\
\hline & $\begin{array}{l}\text { Evitar usar no website a linguagem e a organização interna da } \\
\text { empresa contratante }\end{array}$ & 2 \\
\hline & Atender públicos-alvos diferentes & 1 \\
\hline & Atender vários decisores & 1 \\
\hline \multirow[t]{2}{*}{ Especificação } & $\begin{array}{l}\text { Fazer o contratante compreender os documentos de } \\
\text { especificação }\end{array}$ & 2 \\
\hline & Gerenciar um volume grande de documentos & 1 \\
\hline Total geral & & 13 \\
\hline
\end{tabular}

Cruzando-se a fase em que ocorreram as dificuldades com o foco da questão percebe-se que os focos do contratante e do próprio trabalho de Arquitetura de Informação permeiam todas as fases, porém o foco do contexto tecnológico ocorre apenas na fase de Concepção. Nessa fase é definida a solução macro do projeto, por isso é nela que as restrições tecnológicas precisam ser resolvidas. A Tabela 25 mostra as dificuldades classificadas pela fase do quadro de referência e pelo foco das questões.

Tabela 25 - Classificação das dificuldades nas fases do quadro de referência e pelo foco das questões dos entrevistados

\begin{tabular}{|c|c|c|c|}
\hline Fase & Foco da questão & Dificuldade & Qtd citações \\
\hline \multirow[t]{3}{*}{ Pesquisa } & Contratante & Definir o objetivo do site & 1 \\
\hline & \multirow{2}{*}{$\begin{array}{l}\text { Próprio ao trabalho } \\
\text { de Arquitetura de } \\
\text { Informação }\end{array}$} & Obter acesso as fontes de informação & 1 \\
\hline & & $\begin{array}{l}\text { Produzir um documento conciso e expor os pontos negativos } \\
\text { do website do contratante sem gerar antipatias }\end{array}$ & 1 \\
\hline \multirow[t]{4}{*}{ Concepção } & $\begin{array}{l}\text { Contexto } \\
\text { tecnológico }\end{array}$ & Integrar o website com sistemas legados & 3 \\
\hline & \multirow[t]{2}{*}{ Concepção } & $\begin{array}{l}\text { Evitar usar no website a linguagem e a organização interna da } \\
\text { empresa contratante }\end{array}$ & 2 \\
\hline & & Atender públicos-alvos diferentes & 1 \\
\hline & $\begin{array}{l}\text { Próprio ao trabalho } \\
\text { de Arquitetura de }\end{array}$ & Atender vários decisores & 1 \\
\hline \multirow[t]{2}{*}{ Especificação } & $\begin{array}{l}\text { Contexto } \\
\text { tecnológico }\end{array}$ & $\begin{array}{l}\text { Fazer o contratante compreender os documentos de } \\
\text { especificação }\end{array}$ & 2 \\
\hline & $\begin{array}{l}\text { Próprio ao trabalho } \\
\text { de Arquitetura de }\end{array}$ & Gerenciar um volume grande de documentos & 1 \\
\hline \multicolumn{3}{|l|}{ Total geral } & 13 \\
\hline
\end{tabular}


A seguir todas as dificuldades estão analisadas conforme as fases do quadro de referência.

\subsubsection{Análise das dificuldades dos entrevistados na fase de Pesquisa}

Os entrevistados citaram três dificuldades na fase de Pesquisa e nenhuma dessas foi citada mais que uma única vez.

A primeira dificuldade apontada, definir o objetivo do website, teve como foco da questão o contratante e ocorreu justamente porque o contratante não havia realizado um planejamento estratégico para o website antes de iniciar o projeto de arquitetura de informação. Para o entrevistado 4, que citou essa dificuldade, foi importante superá-la para definir o escopo do projeto e alinhar toda a equipe confirmando a importância desse planejamento visto na investigação teórica.

O entrevistado superou essa dificuldade participando da elaboração do planejamento estratégico do website, embora não seja uma atribuição nem uma especialidade de um arquiteto de informação. Isso foi possível porque esse entrevistado, ao contrário dos demais, trabalha em uma empresa que desenvolve seus próprios websites e assim teve acesso as informações e pessoas que participaram do desenvolvimento desse planejamento estratégico.

Porém, apesar de ter conseguido superar a dificuldade, nem o entrevistado e nem o contratante ficaram totalmente satisfeitos com a solução. Para superar essa dificuldade completamente o entrevistado desejou ter mais prazo.

A segunda dificuldade, teve como foco da questão o próprio trabalho de Arquitetura de Informação e ocorreu porque o entrevistado 3 não tinha acesso as fontes de informação necessárias para realizar seu benchmark adequadamente. Essa dificuldade exemplifica os problemas existentes para se levantar as informações na fase de Pesquisa. $\mathrm{Na}$ situação citada pelo entrevistado, a dificuldade foi conseguir acesso a áreas restritas dos websites dos concorrentes, mas em outras situações essa mesma dificuldade pode ocorrer com outras fontes de informação. 
O entrevistado conseguiu superar essa dificuldade utilizando senhas de acesso de colegas de trabalho, amigos e parentes que coincidentemente eram usuários desses websites. Com isso a dificuldade foi parcialmente superada porque nem todas as partes dos websites dos concorrentes foram acessadas.

Essa estratégia mostra que criatividade e iniciativa são atributos que o arquiteto de informação precisa ter na fase de Pesquisa para levantar as informações que necessita.

Embora o contratante tenha ficado plenamente satisfeito, o entrevistado ficou parcialmente satisfeito porque sua dificuldade não foi totalmente superada. Para superá-la o entrevistado desejou ter acesso aos websites dos concorrentes e imagens de todas as telas desses websites.

Por fim, a última dificuldade também teve como foco da questão o próprio trabalho do arquiteto de informação e retrata uma habilidade importante para esse profissional: o domínio de técnicas para apresentação dos seus documentos, tanto na forma escrita quanto na forma oral, de modo que consiga expor suas idéias de forma eficiente. A causa dessa dificuldade foi o próprio entrevistado, que não gosta de escrever os relatórios de apresentação do seu trabalho.

Para conseguir redigir um relatório objetivo, o entrevistado teve paciência, determinação e contou com a ajuda da equipe de projeto, dividindo e direcionando a confecção do relatório para pessoas com habilidade de escrita. Isso demonstra a importância do trabalho em equipe nos projetos de arquitetura de informação porque permite que profissionais diferentes complementem suas habilidades produzindo um produto melhor.

Já para conseguir expor os pontos negativos do website do contratante, o entrevistado usou de razão e sensibilidade para não gerar antipatias. Pelo lado da razão ele justificou cada ponto negativo apontado. Pelo lado da sensibilidade, o entrevistado foi polido e usou de eufemismos para não aumentar a dimensão dos problemas. Ele também permitiu que o contratante explicasse a razão de um cada dos pontos negativos apontados, uma atitude que não só criou mais empatia com o contratante como também permitiu ao entrevistado conhecer mais detalhes dos problemas que enfrentaria ao longo do projeto. 
A abertura do contratante para ouvir críticas ao seu website e a paciência e determinação do entrevistado também foram fatores que contribuíram para a superação total dessa dificuldade e a satisfação total do contratante e do entrevistado. O entrevistado desejou, para superar essa dificuldade, ter mais habilidade para escrita, poder produzir duas versões do documento (completa e reduzida) e ter redatores na sua equipe de projeto.

A Tabela 26 descreve as dificuldades apontadas pelos entrevistados na fase de Pesquisa. Cada coluna dessa tabela retrata uma dificuldade, analisada conforme os componentes do triangulo do Sense-Making. Respostas que foram citadas por mais de um entrevistado têm a quantidade de citações entre parênteses. 
Tabela 26 - Análise das dificuldades dos entrevistados na fase de Pesquisa

\begin{tabular}{|c|c|c|c|c|}
\hline \multicolumn{2}{|r|}{ Categorias de análise } & \multicolumn{3}{|c|}{ Dificuldades } \\
\hline \multicolumn{2}{|c|}{$\begin{array}{l}\text { Entrevistados que } \\
\text { citaram a dificuldade }\end{array}$} & - Entrevistado 4 & - Entrevistado 3 & - Entrevistado 2 \\
\hline \multirow{2}{*}{ 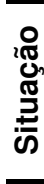 } & $\begin{array}{l}\text { Fase no quadro de } \\
\text { referência }\end{array}$ & Pesquisa & Pesquisa & Pesquisa \\
\hline & $\begin{array}{l}\text { Atividades em que } \\
\text { ocorreu a } \\
\text { dificuldade }\end{array}$ & - Reunião de briefing & - Benchmark & - Documento de análise \\
\hline \multirow{3}{*}{ 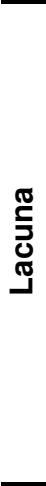 } & Dificuldade & $\begin{array}{l}\text { - Definir o objetivo do } \\
\text { site }\end{array}$ & $\begin{array}{l}\text { - Obter acesso as fontes } \\
\text { de informação }\end{array}$ & $\begin{array}{l}\text { - Produzir um } \\
\text { documento conciso e } \\
\text { expor os pontos } \\
\text { negativos do website do } \\
\text { contratante sem gerar } \\
\text { antipatias }\end{array}$ \\
\hline & $\begin{array}{l}\text { Motivos que } \\
\text { geraram a } \\
\text { dificuldade }\end{array}$ & $\begin{array}{l}\text { - Não foi realizado o } \\
\text { planejamento estratégico } \\
\text { do website antes do } \\
\text { projeto de Arquitetura de } \\
\text { Informação. }\end{array}$ & $\begin{array}{l}\text { - A área restrita do } \\
\text { website dos } \\
\text { concorrentes é paga. }\end{array}$ & $\begin{array}{l}\text { - Não gosta de escrever } \\
\text { o relatório }\end{array}$ \\
\hline & Foco da questão & - Contratante & $\begin{array}{l}\text { - Próprio ao trabalho de } \\
\text { Arquitetura de } \\
\text { Informação }\end{array}$ & $\begin{array}{l}\text { - Próprio ao trabalho de } \\
\text { Arquitetura de } \\
\text { Informação }\end{array}$ \\
\hline$\stackrel{\circ}{\mathscr{S}}$ & $\begin{array}{l}\text { Importância de } \\
\text { superar a } \\
\text { dificuldade }\end{array}$ & $\begin{array}{l}\text { - Para definir o escopo } \\
\text { do projeto } \\
\text { - Para alinhar toda a } \\
\text { equipe do projeto }\end{array}$ & $\begin{array}{l}\text { - Para fazer o } \\
\text { benchmark } \\
\text { adequadamente }\end{array}$ & $\begin{array}{l}\text { - Para conseguir } \\
\text { apresentar os problemas } \\
\text { do website } \\
\text { - Para fazer uma } \\
\text { apresentação objetiva }\end{array}$ \\
\hline \multirow{5}{*}{ 敢 } & $\begin{array}{l}\text { Estratégia utilizada } \\
\text { para superar a } \\
\text { dificuldade }\end{array}$ & $\begin{array}{l}\text { - Focus group } \\
\text { - Pesquisa de } \\
\text { referências } \\
\text { - Reuniões com a equipe } \\
\text { de projeto } \\
\text { - Envolveu o contratante } \\
\text { com o projeto }\end{array}$ & $\begin{array}{l}\text { - Encontrou colegas de } \\
\text { trabalho, amigos e } \\
\text { parentes com acesso as } \\
\text { fontes de informação. }\end{array}$ & $\begin{array}{l}\text { - Dividiu o trabalho com } \\
\text { outros profissionais com } \\
\text { habilidade de escrita } \\
\text { - Paciência } \\
\text { - Determinação } \\
\text { - Eufemismo e polidez } \\
\text { na apresentação } \\
\text { - Justificou os pontos } \\
\text { negativos } \\
\text { - Solicitou ao contratante } \\
\text { que explicasse os } \\
\text { pontos negativos }\end{array}$ \\
\hline & $\begin{array}{l}\text { Grau de superação } \\
\text { da dificuldade }\end{array}$ & - Sim, totalmente & - Sim, parcialmente & - Sim, totalmente \\
\hline & $\begin{array}{l}\text { Satisfação do } \\
\text { Entrevistado } \\
\end{array}$ & - Sim, parcialmente & - Sim, parcialmente & - Sim, totalmente \\
\hline & $\begin{array}{l}\text { Satisfação do } \\
\text { Contratante }\end{array}$ & - Sim, parcialmente & - Sim, totalmente & - Sim, totalmente \\
\hline & $\begin{array}{l}\text { Expectativa do que } \\
\text { ajudaria superar a } \\
\text { dificuldade }\end{array}$ & - Mais prazo & $\begin{array}{l}\text { - Acesso aos websites } \\
\text { dos concorrentes } \\
\text { - Ter imagens de todas } \\
\text { as telas dos websites } \\
\text { dos concorrentes }\end{array}$ & $\begin{array}{l}\text { - Habilidade para } \\
\text { escrever } \\
\text { - Produzir duas versões } \\
\text { do documento (completa } \\
\text { e reduzida) } \\
\text { - Ter redatores na } \\
\text { equipe de projeto } \\
\end{array}$ \\
\hline
\end{tabular}

Respostas citadas mais de uma vez possuem a quantidade de citações entre parenteses.

\subsubsection{Análise das dificuldades dos entrevistados na fase de Concepção}

Os entrevistados apontaram quatro dificuldades na fase de Concepção, sendo a primeira delas a mais citada nessa pesquisa. São elas: integrar o website com sistemas legados, evitar usar no website a linguagem e a organização interna da empresa contratante, atender públicos-alvos diferentes e atender vários decisores. 
A primeira dificuldade, integrar com os sistemas legados, teve como foco da questão o contexto tecnológico e ocorreu porque os sistemas computacionais com os quais o website precisava se integrar não podiam ser modificados. Essa dificuldade foi citada pelos entrevistados 1, 2 e 3 e superá-la era importante para melhorar a usabilidade e a navegação do website.

De fato a integração com sistemas legados é uma dificuldade comum nos projetos de arquitetura de informação, como visto na investigação teórica e faz parte dos requisitos técnicos que o arquiteto de informação precisa atender. Ela surge quando existe a necessidade de implementar nos websites transações que sensibilizem os sistemas computacionais existentes na empresa do contratante. Como normalmente o custo e o prazo para modificar esses sistemas são altos, o arquiteto precisa adaptar a sua solução para que a construção seja viável. O problema apontado pelos entrevistados é que a adaptação da solução sacrifica a usabilidade do website.

Para superar essa dificuldade os entrevistados utilizaram diversas ações: pesquisas de boas práticas, pesquisas de outros websites cuja arquitetura de informação pudesse ser utilizada como referência, análise heurística, envolvimento da área de tecnologia de informação responsável pelo sistema legado, envolvimento do contratante com o projeto, humildade e negociação.

Merece destaque a citação do entrevistado 3 quanto a ter uma atitude de humildade para superar essa dificuldade. Por ter visão ampla e detalhada de todo o website e por especificar o trabalho dos demais profissionais envolvidos é comum que o arquiteto de informação assuma uma posição de liderança nos projetos. Mesmo assim cabe a ele manter uma atitude de humildade e reconhecer a importância dos demais profissionais, porque são eles que irão validar e implementar suas soluções. Se o arquiteto for arrogante no trato com os demais membros da equipe de projeto terá muita dificuldade ao negociar as suas soluções.

Todos os entrevistados citaram que suas estratégias superaram parcialmente a dificuldade, uma vez que nem todas as soluções propostas puderam ser implementadas completamente. Em todos os casos os contratantes ficaram totalmente satisfeitos e a 
maioria dos entrevistados também, uma vez que as soluções que foram implementadas tiveram uma boa relação entre custo e benefício.

Os desejos dos entrevistados para superar essa dificuldade foram: ter mais referências, ter uma coleção de referências organizadas por tema, mais conhecimento e verba para a área de tecnologia de informação e até mesmo um novo sistema legado.

A segunda dificuldade apontada na fase de Concepção, citada pelos entrevistados 2 e 4, foi evitar usar no website a linguagem e a organização interna da empresa. Essa dificuldade teve como foco da questão o contratante e surgiu porque o contratante queria utilizar a sua linguagem e organização própria da sua empresa nos sistemas de organização e rotulação, um problema comum no design desses sistemas, como visto no capítulo 3. Superar essa dificuldade foi importante para se criar rótulos compreensíveis aos usuários, para melhorar a usabilidade e a navegação do website e para definir regras claras para os sistemas que compõem a arquitetura de informação.

Essa dificuldade foi superada com negociação, pesquisa de boas práticas, pesquisas de referência e uma atitude de tentar entender o problema do contratante, mas explicandolhe os problemas de usabilidade decorrentes das suas sugestões. Os entrevistados também citaram que foram favorecidos por um contratante envolvido com o projeto.

Os dois entrevistados conseguiram, com suas estratégias, superar essa dificuldade, embora apenas um deles a superou totalmente. Em ambos os casos o contratante ficou totalmente satisfeito. Quanto a satisfação dos entrevistados um ficou totalmente satisfeito e o outro ficou parcialmente. Apenas um desejo foi citado para essa dificuldade: que o contratante não esqueça dos argumentos do entrevistado para que em novos projetos não tenha que ocorrer essa mesma dificuldade.

A terceira dificuldade, apontada apenas pelo entrevistado 1, foi atender a públicosalvos diferentes. Essa dificuldade teve como foco o próprio trabalho de Arquitetura de Informação e foi motivada pelos requisitos do projeto, nos quais definiu-se que o website deveria atender a três públicos-alvos com necessidades diferentes. Essa é uma dificuldade característica do sistema de organização, como visto no capítulo 3, e superá-la foi importante para que cada público-alvo pudesse encontrar sua respectiva seção no website. 
Para superar essa dificuldade o entrevistado realizou estudo de cenários com propostas de organização e rotulação do website e depois as validou com testes de usabilidade. Ele também contou com um prazo adequado e um ambiente favorável para seguir a sua metodologia.

Como resultado a dificuldade foi totalmente superada e o contratante ficou totalmente satisfeito. $\mathrm{O}$ entrevistado ficou parcialmente satisfeito porque acredita que a solução final do projeto não foi melhor que nenhum dos cenários propostos. O contratante juntou elementos dos diversos cenários que, na opinião do entrevistado, não resultaram em uma solução melhor.

O entrevistado não citou nenhum desejo para ajudá-lo a superar essa dificuldade, apenas desejou que em projetos semelhantes possa também ter prazo adequado.

Por fim a última dificuldade da fase de Concepção, citada apenas pelo entrevistado 5, foi a de ter que atender vários decisores no seu projeto. Essa dificuldade também teve como foco da questão o contratante e foi motivada pela ausência de uma pessoa única por parte da empresa contratante que participasse de todas as discussões do projeto e tivesse poder de decisão. Segundo o entrevistado não havia no projeto uma definição clara de papéis e responsabilidades entre os profissionais da empresa contratante e com isso muitas pessoas com visões diferentes sobre o projeto participavam do processo decisório tornando-o demorado.

Essa dificuldade retrata o problema que as políticas internas da empresa podem causar nos projetos de arquitetura de informação. Como visto no capítulo 3, conflitos de interesse resultantes da disputa política interna da empresa podem afetar negativamente o design do sistema de organização.

A estratégia adotada para superar essa dificuldade por parte do entrevistado foi exigir que o contratante definisse uma pessoa para ser o ponto focal do projeto e atribuísse a ela poder para decidir que solução deveria ser implementada. $\mathrm{O}$ envolvimento do contratante com o projeto e da equipe de desenvolvimento também ajudaram o entrevistado porque criaram um ambiente favorável para implementar essa estratégia. Assim a dificuldade foi totalmente superada e tanto o entrevistado quanto seu contratante 
ficaram totalmente satisfeitos. Para superar essa dificuldade o entrevistado desejou que ele próprio tivesse discernimento para saber como proceder em situações difíceis e que o contratante fosse aberto a mudanças.

A Tabela 27 descreve as dificuldades apontadas pelos entrevistados na fase de Concepção. Cada coluna dessa tabela retrata uma dificuldade, analisada conforme os componentes do triangulo do Sense-Making. Respostas que foram citadas por mais de um entrevistado têm a quantidade de citações entre parênteses. 
Tabela 27 - Análise das dificuldades dos entrevistados na fase de Concepção

\begin{tabular}{|c|c|c|c|c|c|}
\hline \multirow{2}{*}{\multicolumn{2}{|c|}{$\begin{array}{l}\text { Categorias de análise } \\
\text { Entrevistados que } \\
\text { citaram a dificuldade }\end{array}$}} & \multicolumn{4}{|c|}{ Dificuldades } \\
\hline & & $\begin{array}{l}\text { - Entrevistado } 1 \\
\text { - Entrevistado } 2 \\
\text { - Entrevistado } 3\end{array}$ & $\begin{array}{l}\text { - Entrevistado } 2 \\
\text { - Entrevistado } 4\end{array}$ & - Entrevistado 1 & - Entrevistado 5 \\
\hline \multirow[b]{2}{*}{ 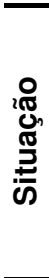 } & $\begin{array}{l}\text { Fase no quadro de } \\
\text { referência }\end{array}$ & Concepção & Concepção & Concepção & Concepção \\
\hline & $\begin{array}{l}\text { Atividades em que } \\
\text { ocorreu a } \\
\text { dificuldade }\end{array}$ & $\begin{array}{l}\text { - Wireframe e Fluxo de } \\
\text { navegação } \\
\text { - Elaboração da macro- } \\
\text { arquitetura } \\
\text { - Requisitos e } \\
\text { Documento de análise }\end{array}$ & $\begin{array}{l}\text { - Elaboração da macro- } \\
\text { arquitetura } \\
\text { - Macro-arquitetura }\end{array}$ & - Infograma & $\begin{array}{l}\text { - Mapa informacional, } \\
\text { Wireframes e Desenvolve } \\
\text { as alternativas }\end{array}$ \\
\hline \multirow{3}{*}{ 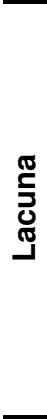 } & Dificuldade & $\begin{array}{l}\text { - Integrar o website com } \\
\text { sistemas legados (3) }\end{array}$ & $\begin{array}{l}\text { - Evitar usar no website } \\
\text { a linguagem e a } \\
\text { organização interna da } \\
\text { empresa contratante (2) }\end{array}$ & $\begin{array}{l}\text { - Atender públicos-alvos } \\
\text { diferentes }\end{array}$ & $\begin{array}{l}\text { - Atender vários } \\
\text { decisores }\end{array}$ \\
\hline & $\begin{array}{l}\text { Motivos que } \\
\text { geraram a } \\
\text { dificuldade }\end{array}$ & $\begin{array}{l}\text { - Sistemas legados que } \\
\text { não podem ser } \\
\text { modificados. (3) }\end{array}$ & $\begin{array}{l}\text { - Contratante deseja } \\
\text { utilizar no website a } \\
\text { linguagem e organização } \\
\text { da sua } \\
\text { empresa (2) }\end{array}$ & $\begin{array}{l}\text { - Haviam três públicos- } \\
\text { alvos com necessidades } \\
\text { distintas que o website } \\
\text { precisava atender }\end{array}$ & $\begin{array}{l}\text { Não havia um } \\
\text { representante único do } \\
\text { contratante para tomada } \\
\text { de decisão }\end{array}$ \\
\hline & Foco da questão & - Contexto tecnológico & - Contratante & $\begin{array}{l}\text { - Próprio ao trabalho de } \\
\text { Arquitetura de } \\
\text { Informação }\end{array}$ & - Contratante \\
\hline$\stackrel{\circ}{\supset}$ & $\begin{array}{l}\text { Importância de } \\
\text { superar a } \\
\text { dificuldade }\end{array}$ & $\begin{array}{l}\text { - Para melhorar a } \\
\text { usabilidade das } \\
\text { transações (3) } \\
\text { - Para melhorar a } \\
\text { navegação no website. }\end{array}$ & $\begin{array}{l}\text { - Para definir regras } \\
\text { claras para os sistemas } \\
\text { de organização, } \\
\text { navegação e rotulação } \\
\text { - Para melhorar a } \\
\text { usabilidade das } \\
\text { transações. } \\
\text { - Para criar rótulos } \\
\text { compreensíveis ao } \\
\text { usuário } \\
\text { Para melhorar a } \\
\text { navegação no website. }\end{array}$ & $\begin{array}{l}\text { - Para cada público-alvo } \\
\text { encontrar sua respectiva } \\
\text { seção no website }\end{array}$ & $\begin{array}{l}\text { - Para definir qual cenário } \\
\text { implementar }\end{array}$ \\
\hline \multirow{5}{*}{ 㞼 } & $\begin{array}{l}\text { Estratégia utilizada } \\
\text { para superar a } \\
\text { dificuldade }\end{array}$ & $\begin{array}{l}\text { - Pesquisa de } \\
\text { boas práticas (2) } \\
\text { - Pesquisa de } \\
\text { referências (2) } \\
\text { - Análise heurística } \\
\text { - Envolvimento de } \\
\text { Tecnologia de } \\
\text { Informação desde o } \\
\text { início do projeto } \\
\text { - Envolvimento do } \\
\text { contratante com o } \\
\text { projeto } \\
\text { - Humildade } \\
\text { - Negociação }\end{array}$ & $\begin{array}{l}\text { - Negociação (2) } \\
\text { - Atitude de tentar } \\
\text { entender a posição da } \\
\text { outra parte } \\
\text { - Envolvimento do } \\
\text { contratante com o } \\
\text { projeto } \\
\text { - Explicar os problemas } \\
\text { de usabilidade } \\
\text { decorrentes das } \\
\text { sugestões do } \\
\text { contratante } \\
\text { - Pesquisa de } \\
\text { boas práticas } \\
\text { - Pesquisa de } \\
\text { referências }\end{array}$ & $\begin{array}{l}\text { - Estudo de cenário } \\
\text { - Prazo adequado } \\
\text { - Ambiente favorável } \\
\text { para seguir a } \\
\text { metodologia de projetos } \\
\text { de arquitetura de } \\
\text { informação } \\
\text { - Teste de usabilidade }\end{array}$ & $\begin{array}{l}\text { - Envolvimento do } \\
\text { contratante com o projeto } \\
\text { - Equipe de } \\
\text { desenvolvimento } \\
\text { - Exigiu do contratante a } \\
\text { definição de um } \\
\text { representante único }\end{array}$ \\
\hline & $\begin{array}{l}\text { Grau de superação } \\
\text { da dificuldade }\end{array}$ & - Sim, parcialmente (3) & $\begin{array}{l}\text { - Sim, totalmente } \\
\text { - Sim, parcialmente }\end{array}$ & - Sim, totalmente & - Sim, totalmente \\
\hline & \begin{tabular}{|l|} 
Satisfação do \\
Entrevistado
\end{tabular} & $\begin{array}{l}\text { - Sim, totalmente (2) } \\
\text { - Sim, parcialmente }\end{array}$ & $\begin{array}{l}\text { - Sim, totalmente } \\
\text { - Sim, parcialmente }\end{array}$ & - Sim, parcialmente & - Sim, totalmente \\
\hline & $\begin{array}{l}\text { Satisfação do } \\
\text { Contratante } \\
\end{array}$ & - Sim, totalmente (3) & - Sim, totalmente (2) & - Sim, totalmente & - Sim, totalmente \\
\hline & $\begin{array}{l}\text { Expectativa do que } \\
\text { ajudaria superar a } \\
\text { dificuldade }\end{array}$ & $\begin{array}{l}\text { - Mais referências } \\
\text { - Coleção de referências } \\
\text { organizadas por tema } \\
\text { - Mais conhecimento na } \\
\text { área de Tecnologia de } \\
\text { Informação } \\
\text { - Mais verba para a área } \\
\text { de Tecnologia de } \\
\text { Informação } \\
\text { - Novo sistema legado }\end{array}$ & $\begin{array}{l}\text { - Que o contratante } \\
\text { nunca mais esqueça os } \\
\text { argumentos do arquiteto } \\
\text { de informação }\end{array}$ & $\begin{array}{l}\text { - Mais prazo (não nesse } \\
\text { projeto, mas nos } \\
\text { próximos) }\end{array}$ & $\begin{array}{l}\text { - Discernimento para } \\
\text { saber como proceder em } \\
\text { situações difíceis } \\
\text { - Contratantes abertos a } \\
\text { mudanças }\end{array}$ \\
\hline
\end{tabular}

Respostas citadas mais de uma vez possuem a quantidade de citações entre parenteses. 


\subsubsection{Análise das dificuldades dos entrevistados na fase de Especificação}

Para a fase de Especificação, os entrevistados citaram apenas duas dificuldades, ambas relacionadas com a produção dos documentos característicos dessa fase. São elas: fazer o contratante entender os documentos de especificação e gerenciar um volume grande de documentos.

A primeira dificuldade teve como foco da questão o contratante e foi motivada por dois fatores que retratam uma dicotomia presente na interpretação dos documentos de especificação da arquitetura de informação.

O primeiro fator apontado é a dificuldade das pessoas em interpretar os documentos de Arquitetura de Informação por não estarem familiarizadas com eles. Como visto no capítulo 4 por ser um campo novo é comum o arquiteto se deparar com pessoas que não conhecem o objetivo de cada tipo de documento, como são organizados e o vocabulário visual utilizado. Por isso essas pessoas precisam de treinamento para interpretar tais documentos, uma vez que não são documentos de uso comum. Assim, muitas vezes o arquiteto de informação precisa sensibilizar seu leitor.

Essa foi a estratégia adotada pelo entrevistado 5. Ele analisou o perfil do contratante e lhe explicou sua metodologia e cada tipo de documento produzido. Ele também contou com o envolvimento do contratante com o projeto e dessa forma a dificuldade foi superada, satisfazendo totalmente ele e o contratante. Esse entrevistado não desejou nada para auxiliá-lo a superar essa dificuldade. Apenas desejou que em próximos projetos possa novamente ter contratantes bastante envolvidos.

O outro fator apontado que motivou a dificuldade de compreensão dos documentos de especificação da arquitetura de informação é que o leitor pode não ter a capacidade de abstração necessária para entender os documentos de especificação. Os documentos elaborados na fase de Especificação, por serem uma modelagem do website, não são uma representação realista do produto final. Eles são focados nas características relacionadas à organização da informação e dão menos atenção as demais. Além disso, nem sempre é possível retratar no papel toda a interatividade da Web, como foi citado pelo entrevistado 2, no levantamento da sua metodologia (veja Tabela 16). 
Para compreender tais documentos é necessário que o leitor tenha uma capacidade de abstração que não é comum a pessoas sem experiência com projetos na Web. $\mathrm{O}$ arquiteto ao se deparar com pessoas desse tipo precisa ter flexibilidade para produzir seus documentos de uma forma que permita aos seus leitores compreende-los. Assim, muitas vezes o arquiteto precisa criar uma linguagem para seu leitor.

O entrevistado 2 não conseguiu fazer com que seu contratante compreendesse os documentos de arquitetura de informação com níveis mais altos de abstração (o sitegrama e o fluxo de navegação). Assim, para contornar essa dificuldade, ele adaptou para o contratante a sua forma de elaborar a documentação e acabou por fazê-la toda em wireframes, os quais possuem um nível mais baixo de abstração. Os wireframes representam o website de forma mais realista que o sitegrama e o fluxo de navegação, porém são mais demorados para serem produzidos.

A estratégia resultou em um contratante totalmente satisfeito, mas o entrevistado ficou insatisfeito com a solução porque o projeto avançou no prazo planejado e produziu uma documentação extensa e difícil de gerenciar. O seu desejo para superar essa dificuldade foram dois: fazer o contratante entender os documentos com nível mais alto de abstração ou conseguir saber, antes de iniciar um projeto, se o contratante possui capacidade de abstração para compreender esses documentos de modo que possa prever nos seus projetos mais horas para a produção de wireframes se for necessário.

A segunda dificuldade apontada na fase de Especificação, gerenciar um volume grande de wireframes, também foi citada pelo entrevistado 2 e foi decorrente da sua dificuldade anterior. Essa dificuldade teve como foco o próprio trabalho de arquitetura de informação e ocorreu porque o grande volume de wireframes produzidos tornou o trabalho de gerenciá-los muito difícil já que a cada revisão muitos documentos eram afetados.

Como visto na investigação teórica, bons documentos de especificação possuem redundância mínima justamente para facilitar o trabalho de revisão. Nos documentos de Arquitetura de Informação, a diminuição da redundância se consegue utilizando o sitegrama e o fluxo de navegação, para representar os relacionamentos e a navegação entre as páginas nas diversas situações de uso do website. Os wireframes são utilizados apenas para especificar páginas modelo. 
Como no caso citado, o entrevistado teve de fazer wireframes de todas as páginas do website, a documentação ficou muito redundante e volumosa e cada revisão exigia que diversos pontos do documento fossem alterados.

Segundo o entrevistado a dificuldade não foi superada. A utilização de um software com múltiplos templates facilitou a produção dos wireframes, mas não resolveu o problema. Também trabalharam na produção desses wireframes arquitetos com diferentes perfis (juniores, plenos e seniores), o que permitiu reduzir um pouco o custo total do projeto. $\mathrm{O}$ entrevistado ficou parcialmente satisfeito com a solução, mas seu contratante ficou totalmente satisfeito porque recebeu os wireframes de todas as páginas do site.

O desejo do entrevistado para superar essa dificuldade reflete um apontamento feito na investigação teórica: os arquitetos de informação são carentes de ferramentas CASE que automatizam o trabalho de produção dos seus documentos.

A Tabela 28 descreve as dificuldades apontadas pelos entrevistados na fase de Concepção. Cada coluna dessa tabela retrata uma dificuldade, analisada conforme os componentes do triangulo do Sense-Making. Respostas que foram citadas por mais de um entrevistado têm a quantidade de citações entre parênteses. 
Tabela 28 - Análise das dificuldades dos entrevistados na fase de Pesquisa

\begin{tabular}{|c|c|c|c|c|}
\hline \multirow{2}{*}{\multicolumn{2}{|c|}{$\begin{array}{l}\text { Categorias de análise } \\
\text { Entrevistados que } \\
\text { citaram a dificuldade }\end{array}$}} & \multicolumn{3}{|c|}{ Dificuldades } \\
\hline & & - Entrevistado 5 & - Entrevistado 2 & - Entrevistado 2 \\
\hline \multirow{2}{*}{ 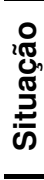 } & Fase & Especificação & Especificação & Especificação \\
\hline & $\begin{array}{l}\text { Atividades em que } \\
\text { ocorreu a } \\
\text { dificuldade }\end{array}$ & $\begin{array}{l}\text { - Mapa informacional e } \\
\text { Wireframes }\end{array}$ & - Detalhamento & - Detalhamento \\
\hline \multirow{3}{*}{ 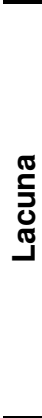 } & Dificuldade & \multicolumn{2}{|c|}{$\begin{array}{l}\text { - Fazer o contratante compreender os documentos } \\
\text { de especificação (2) }\end{array}$} & $\begin{array}{l}\text { - Gerenciar um volume } \\
\text { grande de documentos }\end{array}$ \\
\hline & $\begin{array}{l}\text { Motivos que } \\
\text { geraram a } \\
\text { dificuldade }\end{array}$ & $\begin{array}{l}\text { - Contratante não } \\
\text { conhece a metodologia } \\
\text { de Arquitetura de } \\
\text { Informação e os } \\
\text { documentos de } \\
\text { especificação }\end{array}$ & \begin{tabular}{|l|} 
- Contratante não tem \\
capacidade de abstração \\
para entender os \\
documentos de \\
especificação de alto \\
nível (sitegrama e fluxos \\
de navegação)
\end{tabular} & $\begin{array}{l}\text { - Executar as revisões } \\
\text { foi trabalhoso porque } \\
\text { muitos documentos } \\
\text { eram afetados }\end{array}$ \\
\hline & Foco da questão & - Contratante & - Contratante & $\begin{array}{l}\text { - Próprio ao trabalho de } \\
\text { Arquitetura de } \\
\text { Informação }\end{array}$ \\
\hline$\stackrel{\leftrightarrow}{\supset}$ & $\begin{array}{l}\text { Importância de } \\
\text { superar a } \\
\text { dificuldade }\end{array}$ & $\begin{array}{l}\text { - Para adquirir a } \\
\text { confiança do contratante } \\
\text { e aumentar sua } \\
\text { participação no projeto }\end{array}$ & $\begin{array}{l}\text { - Para diminuir o tempo } \\
\text { de produção e revisão } \\
\text { dos documentos }\end{array}$ & $\begin{array}{l}\text { - Para diminuir o tempo } \\
\text { de produção e revisão } \\
\text { dos documentos }\end{array}$ \\
\hline \multirow{5}{*}{ 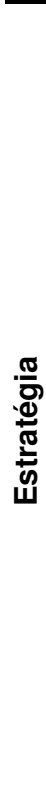 } & $\begin{array}{l}\text { Estratégia utilizada } \\
\text { para superar a } \\
\text { dificuldade }\end{array}$ & $\begin{array}{l}\text { - Análise do perfil do } \\
\text { contratante } \\
\text { - Envolver o contratante } \\
\text { com o projeto } \\
\text { - Negociação }\end{array}$ & $\begin{array}{l}\text { - Produziu os wireframes } \\
\text { de todas as telas }\end{array}$ & $\begin{array}{l}\text { - Utilizou um software } \\
\text { com múltiplos templates } \\
\text { para a produção dos } \\
\text { wireframes } \\
\text { - Ter múltiplos perfis de } \\
\text { arquitetos na equipe: } \\
\text { juniores, plenos e } \\
\text { seniores }\end{array}$ \\
\hline & $\begin{array}{l}\text { Grau de superação } \\
\text { da dificuldade }\end{array}$ & - Sim, totalmente & - Não & - Não \\
\hline & $\begin{array}{l}\text { Satisfação do } \\
\text { Entrevistado }\end{array}$ & - Sim, totalmente & - Não & - Sim, parcialmente \\
\hline & $\begin{array}{l}\text { Satisfação do } \\
\text { contratante }\end{array}$ & - Sim, totalmente & - Sim, totalmente & - Sim, totalmente \\
\hline & $\begin{array}{l}\text { Expectativa do que } \\
\text { ajudaria superar a } \\
\text { dificuldade }\end{array}$ & $\begin{array}{l}\text { - Contratantes mais } \\
\text { parceiros (não nesse } \\
\text { projeto, mas nos } \\
\text { próximos) }\end{array}$ & \begin{tabular}{|l|} 
- Contratantes que \\
entendam os \\
documentos de alto nível \\
- Saber, antes de fazer o \\
orçamento, se o \\
contratante não entende \\
os documentos de alto \\
nível para prever mais \\
horas de produção dos \\
wireframes
\end{tabular} & $\begin{array}{l}\text { - Software com } \\
\text { bibliotecas e templates } \\
\text { que automatize a } \\
\text { produção dos } \\
\text { documentos de } \\
\text { especificação }\end{array}$ \\
\hline
\end{tabular}

\subsubsection{Análise das estratégias adotadas}

As estratégias dos entrevistados foram classificadas nos focos das questões através das dificuldades em que foram adotadas. Essa análise mostra quais estratégias foram empregadas em cada foco de questão e a eficiência delas. 
As estratégias mais utilizadas nas dificuldades com foco da questão no contratante são o envolvimento dele com o projeto, negociação e outras semelhantes (análise do perfil do contratante, atitude de tentar entender a posição da outra parte, exigiu do contratante a definição de um representante único e explicou os problemas de usabilidade decorrentes das sugestões do contratante). Essas estratégias tiveram sucesso na superação da dificuldade, o que mostra a importância do arquiteto de informação ter boas habilidades de negociação, confirmando a investigação teórica.

Com relação às dificuldades com foco da questão no próprio trabalho de Arquitetura de Informação, nenhuma estratégia se destacou e de forma geral as estratégias adotadas foram eficientes. Pode-se observar nessas estratégias que os arquitetos de informação lançaram mão de diferentes habilidades para superar suas dificuldades: paciência, determinação, habilidade para apresentar seu trabalho, criatividade e iniciativa (as duas últimas utilizadas para encontrar colegas de trabalho, amigos e parentes com acesso as fontes de informação). Um ambiente favorável para seguir a metodologia de projetos e um prazo adequado também ajudaram a superar essas dificuldades.

Por fim o que se observa nas estratégias adotadas para superar as dificuldades com foco da questão no contexto tecnológico é que elas se baseiam principalmente na pesquisa de soluções (pesquisa de boas práticas e pesquisas de referência) e na negociação com a área de tecnologia de informação. Porém nenhuma estratégia adotada foi completamente eficiente. A Tabela 29 mostra as estratégias adotada pelos entrevistados classificadas pelo foco da questão. 
Tabela 29 - Classificação das estratégias pelo foco das questões dos entrevistados

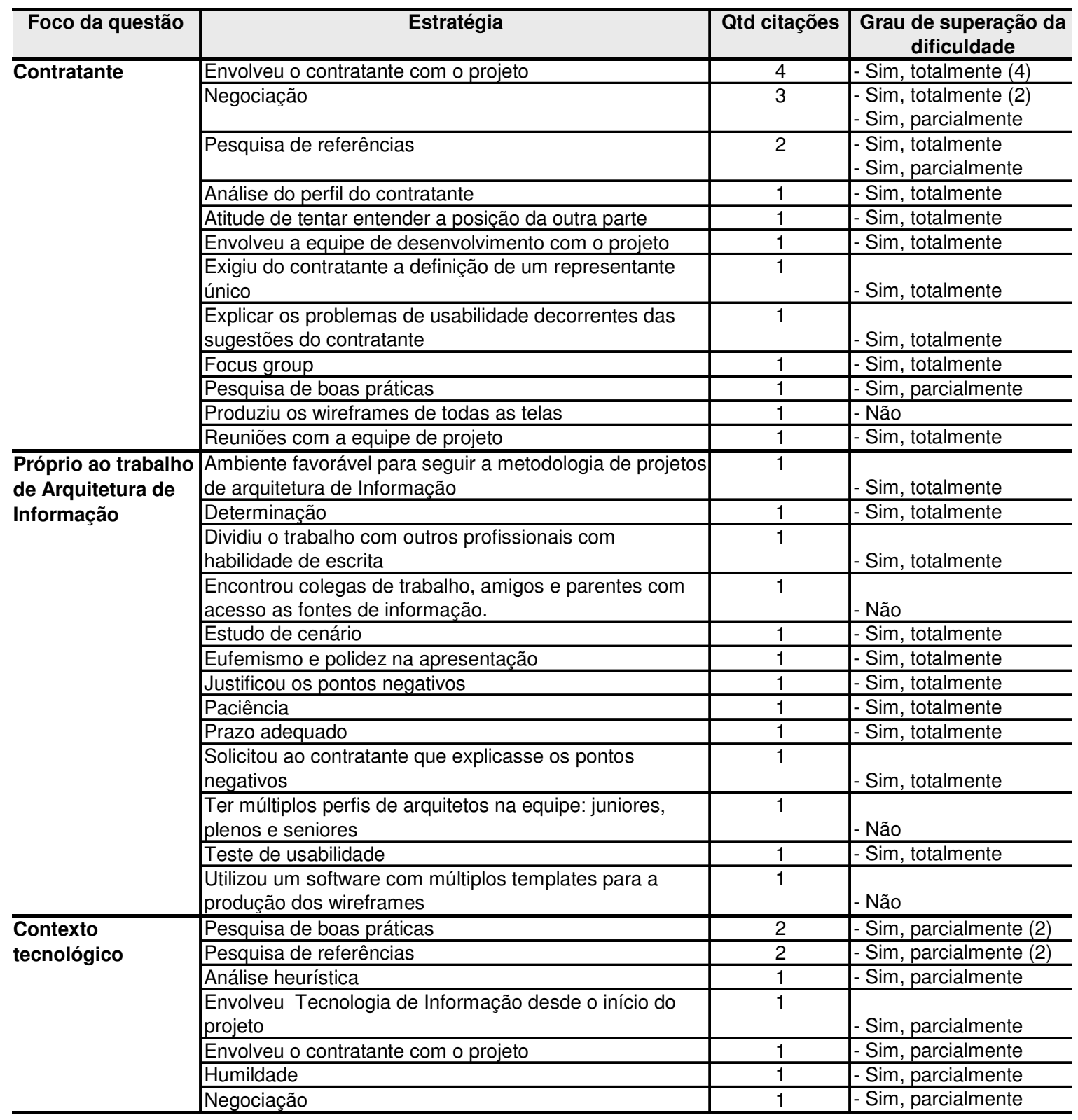

\subsubsection{Síntese dos resultados encontrados}

Essa pesquisa mostrou que os arquitetos de informação experientes adotam uma metodologia nos seus projetos de arquiteta de informação, algumas delas documentadas, outras guardadas no conhecimento tácito dos funcionários das suas empresas. E apesar das diferenças de nomenclaturas e atividades, existe muita similaridade entre elas.

Os arquitetos concordam com suas metodologias pelos seguintes motivos: a comprovaram na prática, elas caminham de uma visão macro para uma visão detalhada ao 
longo do projeto e elas os ajudam a terem argumentos palpáveis e racionais para negociar suas soluções.

Na maioria dos projetos, as metodologias são seguidas em todas as suas atividades. A exceção são projetos pequenos, projetos com solução conhecida, projetos com restrição de prazo e casos de resistência do contratante. Assim, as metodologias de projetos de arquitetura de informação precisam ser flexíveis e oferecer atalhos.

Analisando-se as metodologias segundo o quadro de referência formulado na investigação teórica foi possível encontrar atividades que correspondem a cada uma das suas fases: Pesquisa, Concepção, Especificação, Implementação e Avaliação.

A análise da fase de Pesquisa nas metodologias levantadas mostra que o design do website é mais centrado na empresa contratante e nos seus problemas internos que nos usuários. São raros os casos em que são feitas pesquisas diretas com usuários, o que demonstra que essas metodologias não seguem a abordagem de Design Centrado no Usuário da Ciência da Informação.

A fase de Concepção não apresenta uma separação muito clara da fase de Pesquisa, com a qual compartilha técnicas e atividades. $\mathrm{O}$ arquiteto lidera essa fase, mas conta com a ajuda de outros profissionais para gerar idéias e validar sua soluções.

As técnicas empregadas nessa fase são, na sua maioria, técnicas de geração de idéias utilizadas para definir os conceitos e as regras dos sistemas de organização, de navegação, de rotulação e de busca. Poucos testes de usabilidade são realizados porque não se consegue convencer os contratantes da importância e também porque não existe pleno domínio das técnicas mais adequadas à Arquitetura de Informação. Isso demonstra que as metodologias dos entrevistados seguem pouco a abordagem de Design Centrado no Usuário da Interação Humano-Computador.

Na fase de Especificação também não existe uma separação clara da fase anterior. $\mathrm{O}$ arquiteto de informação também é o principal ator dessa fase, mas continua a contar com o auxílio das áreas de projeto gráfico e tecnologia de informação. Os documentos 
produzidos nessa fase são os apontados na investigação teórica: o sitegrama, o fluxo de navegação e os wireframes.

Com relação à fase de Implementação, existe pouca preocupação com essa fase, confirmando a investigação teórica.

Também foi observada pouca preocupação com a fase de Avaliação que, quando existe, fica inteiramente a cargo da empresa contratante e raramente o arquiteto tem acesso aos relatórios de avaliação.

Com relação as dificuldades, foi observado que a maioria delas tem em comum o foco o contratante e ocorrem mais na fase de Concepção.

As principais dificuldades na fase de Pesquisa são: definir o objetivo do website, obter acesso as fontes de informação e produzir um documento conciso expondo os pontos negativos do website do contratante sem gerar antipatias. Para superá-las, o arquiteto emprega sua criatividade, iniciativa e o domínio de técnicas de apresentação. Ele também pode participar do planejamento estratégico do website, embora não seja sua atribuição e não tenha todas as habilidades necessárias.

$\mathrm{Na}$ fase de Concepção as principais dificuldades são integrar o website com sistemas legados, evitar usar no website a linguagem e a organização interna do contratante, atender a públicos-alvos diferentes e atender vários decisores. Para superá-las o arquiteto realiza pesquisa de boas práticas e referências, estudos de cenário, análises heurística, testes de usabilidade, envolve a área de tecnologia de informação e o contratante com o projeto, negocia e tem uma atitude de humildade perante os demais membros do time de projeto.

E na fase de Especificação as principais dificuldades apontadas são: fazer o contratante compreender os documentos de especificação e gerenciar um volume grande desses documentos. Para superar a primeira dificuldade, o arquiteto precisa sensibilizar o seu leitor ou criar uma linguagem para ele. Já a segunda dificuldade ainda não é totalmente superada. Falta para o arquiteto de informação ferramentas de software, especialmente ferramentas CASE, que automatizem a produção e o gerenciamento dos seus documentos. 
Com relação as estratégias temos que para as dificuldades com foco no contratante a negociação e o envolvimento do contratante são as mais adotadas com bastante sucesso.

Nas dificuldades com foco no próprio trabalho de arquitetura de informação as estratégias resultaram de diversas habilidades dos entrevistados, como paciência, determinação, habilidade em apresentar o seu trabalho, criatividade e iniciativa. Essas estratégias também apresentaram sucesso.

Já nas dificuldades com foco no contexto tecnológico, as estratégias se basearam na pesquisa de soluções e na negociação com a área de tecnologia de informação, porém não foram completamente eficientes. 


\section{Considerações finais}

O nosso mundo contemporâneo produz uma quantidade gigantesca de informação nunca antes vivenciada na história da humanidade. São bilhões de gigabytes de informação nova produzidos todos os anos, sendo a Internet o maior catalisador desse fenômeno. Esse admirável mundo novo precisa de novas formas de organizar suas informações, do contrário sucumbiremos em uma montanha de dados incompreensíveis.

A Arquitetura de Informação é uma resposta para essa necessidade, um novo campo multi-disciplinar com o objetivo de organizar a informação para satisfazer as necessidades dos usuários tornando o complexo claro.

É justamente na organização da Web que a Arquitetura de Informação tem encontrado sua maior aplicação atualmente. Ela se tornou uma das disciplinas essenciais para o projeto de websites, sendo a responsável por definir a estrutura organizacional da informação sobre a qual todas as demais partes se apoiarão.

Um projeto da arquitetura de informação de um website cria seus quatro componentes fundamentais: os sistemas de organização, de navegação, de rotulação e de busca. E por ser um problema complexo, com muitas variáveis, esses projetos precisam 
seguir uma metodologia para reduzir o caráter intuitivo dos seus métodos, organizar o trabalho e garantir a qualidade do produto final, do contrário as chances de falha aumentam.

O objetivo desse trabalho foi estudar as práticas de projetos de arquitetura de informação de websites com profissionais brasileiros que atuam na área para verificar o grau de aderência com as propostas teóricas de metodologias de projetos dessa natureza.

Dado que o objetivo da Arquitetura de Informação é construir espaços informacionais que satisfaçam às necessidades dos usuários, esse trabalho teve como foco para sua análise as abordagens de Design Centrado no Usuário da Interação HumanoComputador e da Ciência da Informação.

A abordagem de Design Centrado no Usuário da Interação Humano-Computador surgiu com a popularização dos computadores, quando pessoas sem conhecimento em informática passaram a utilizar essas máquinas e por isso necessitavam de interfaces mais fáceis de usar. Um conceito chave na Interação Humano-Computador é a Usabilidade, definida como a medida na qual um produto pode ser usado por usuários específicos para alcançar objetivos específicos com efetividade, eficiência e satisfação num contexto específico de uso. A abordagem de Design Centrado no Usuário da Interação HumanoComputador tem por características: focalizar no usuário e nas tarefas que realizada, utilizar medidas empíricas da usabilidade do produto observando a interação do usuário com ele e empregar um processo de design iterativo e interativo com refinamentos sucessivos.

De forma complementar temos a abordagem de Design Centrado no Usuário na visão da Ciência da Informação, a qual nasceu de uma mudança de paradigma que essa disciplina vivenciou a partir da década de 70 , quando pesquisadores começaram a se preocupar em compreender os aspectos cognitivos e comportamentais dos usuários quando estão buscando informações. Essa mudança de paradigma questionou as abordagens tradicionais dos estudos de usuários e necessidades de informação existentes na época, cujo foco era centrado no sistema. Surgiu a abordagem alternativa dos estudos de usuários e necessidades de informação, que centra seu foco no usuário. Essa nova abordagem é caracterizada por observar o usuário de um sistema de informação como um cliente, 
estudar suas necessidades e a maneira como ele interage com o mundo para satisfazê-las, ter uma visão holística dele e empregar técnicas de pesquisa qualitativa.

Ambas as abordagens de Design Centrado no Usuário trazem contribuições importantes para a Arquitetura de Informação. A abordagem da Interação HumanoComputador tem uma visão mais operacional, focada em compreender como o usuário executa suas tarefas ao interagir com interfaces computacionais. Já a abordagem da Ciência da Informação tem uma visão holística do usuário e preocupa-se em compreender suas necessidades, a situação em que se encontra e o seu comportamento ao buscar informação.

A revisão da literatura feita nesse trabalho apontou que as principais dificuldades para organizar informação na Web estão relacionadas ao design de três dos quatro componentes fundamentais da Arquitetura de Informação, que apresentam maior independência: os sistemas de organização, de navegação e de rotulação. As principais dificuldades do design desses três são ambigüidade, heterogeneidade, diferenças de perspectiva, políticas internas, estética, localizar o usuário no website, ausência de padrões, falar na linguagem do usuário, superar a ausência de feedback e manter a consistência.

A investigação teórica das metodologias de projetos de arquitetura de informação de websites formulou um quadro de referência para analisá-las com os seguintes princípios:

- As metodologias devem possuir cinco fases distintas:

- Pesquisa: na qual são pesquisadas e analisadas as informações sobre os usuários, suas necessidades e o seu ambiente para definir o escopo e os requisitos do projeto.

○ Concepção: uma fase eminentemente criativa, na qual se concebe a visão macro da solução.

○ Especificação: na qual a visão macro da solução é detalhada em documentos e diagramas que explicam como construir o website. 
○ Implementação: na qual website é construído conforme especificado e disponibilizado para uso.

○ Avaliação: na qual o resultado do projeto é avaliado em função dos seus objetivos iniciais para se registrar os acertos e erros.

- Aplicar na fase de Pesquisa os fundamentos e técnicas das abordagens de Design Centrado no Usuário da Ciência da Informação de forma a buscar uma visão holística do usuário e uma compreensão global de suas situações particulares de uso de informação, incluindo o antes e o depois de suas interações com o website.

- Aplicar na fase de Concepção os fundamentos e técnicas do Design Centrado no Usuário da Interação Humano-Computador de forma a focalizar no usuário e nas suas tarefas desde o início do projeto a ter um processo de design com um ciclo iterativo e interativo de definição, validação e refinamento da solução utilizando avaliações de usabilidade.

Foram encontradas na literatura apenas três metodologias de projeto de arquitetura de informação descritas com detalhamento suficiente que permitiu que fossem analisadas segundo o quadro de referência

Em todas essas metodologias, a maior atenção dos autores é para com as três primeiras fases do quadro de referência: Pesquisa, Concepção e Especificação. Para essas fases são descritas várias técnicas e atividades.

Para a fase de Implementação os autores dedicam poucos comentários. A ausência dessa fase pode fazer com que o website não seja implementado conforme foi especificado pelo arquiteto de informação, inutilizando parte do seu trabalho.

A fase de Avaliação é outro ponto carente nas metodologias analisadas. Em algumas propostas são sugeridas técnicas oriundas da Usabilidade para mensurar os resultados dos projetos, mas os autores não detalham quais técnicas e como empregá-las. Ainda não existe uma adaptação dessas técnicas para mensurar atributos próprios da Arquitetura de Informação. 
Um ponto forte visto nessas metodologias é a influência da abordagem do Design Centrado no Usuário da Interação Humano-Computador. O ciclo interativo e iterativo sugerido nessa abordagem está presente em todas elas assim como o emprego de técnicas de avaliação de usabilidade. Com certeza a influência dessa abordagem melhora a qualidade dos projetos de arquitetura de informação produzindo websites mais fáceis de usar.

Porém a abordagem de Design Centrado no Usuário da Ciência da Informação têm pouca influência nessas metodologias. A ausência desse tipo de abordagem leva a um conhecimento superficial das necessidades de informação dos usuários e, consequentemente, a websites que não as atendam completamente.

$\mathrm{Na}$ investigação empírica foram feitas duas pesquisas de campo. A primeira levantou o perfil do arquiteto de informação das listas de discussão brasileiras e retratou um profissional jovem, que vive nos grandes centros metropolitanos do país e que ainda está descobrindo seu campo de trabalho. É um profissional com alto grau de instrução, formação predominante na área de humanas e que desenvolveu seus conhecimentos sobre Arquitetura de Informação de maneira autodidata.

Entre as atividades que desempenha, esse profissional se concentra mais naquelas relacionadas às fases de Pesquisa, Concepção e Especificação. Pouca atenção é dedicada a fase de Implementação e Avaliação, confirmando a investigação teórica.

Quase metade deles não segue qualquer metodologia em seus projetos. Entre os que seguem, a maioria utiliza metodologias próprias desenvolvidas com base em suas experiências e estudos autodidatas.

$\mathrm{O}$ arquiteto de informação brasileiro carece de uma formação mais multidisciplinar que equilibre as áreas de Exatas e Humanas, de cursos de formação sobre Arquitetura de Informação e de uma metodologia de projetos para orientar o seu trabalho.

Segundo LATHAM (2002) são necessários três componentes para se legitimar uma profissão: estabelecer uma metodologia, desenvolver um corpo teórico que suporte essa metodologia e desenvolver um sistema de educação para formar futuros profissionais. 
Assim, a falta de cursos e o alto número de profissionais que não seguem uma metodologia compromete a legitimação da profissão de arquiteto de informação no Brasil.

A segunda pesquisa levantou as dificuldades que os profissionais de arquitetura de informação enfrentam nos seus projetos e quais técnicas e metodologias utilizam para superá-las. Nela foi observado que os arquitetos de informação experientes adotam uma metodologia nos seus projetos e, apesar das diferenças de nomenclaturas e atividades, existe muita similaridade entre elas. Essa pesquisa também validou na prática o quadro de referência formulado na investigação teórica.

$\mathrm{Na}$ análise dessas metodologias pelo quadro de referência foi possível encontrar atividades que correspondem a cada uma das suas fases: Pesquisa, Concepção, Especificação, Implementação e Avaliação.

A análise da fase de Pesquisa nas metodologias pesquisadas na prática mostrou que raramente são feitas pesquisas diretas com os usuários tornando os projetos mais centrado na empresa contratante, o que demonstra que essas metodologias não seguem a abordagem de Design Centrado no Usuário da Ciência da Informação, confirmando a investigação teórica.

$\mathrm{Na}$ fase de Concepção não foi observada uma separação clara da fase anterior. O arquiteto lidera essa fase, mas conta com a ajuda de outros profissionais para gerar idéias e validar sua soluções. A maioria das técnicas empregadas nessa fase são para geração de idéias e utilizadas para definir os conceitos e as regras dos quatro sistemas que compõem a arquitetura de informação do website. Poucos testes de usabilidade são realizados dado que não se consegue convencer os contratantes da importância desses testes e também por não haver pleno domínio das técnicas mais adequadas à Arquitetura de Informação. Isso demonstra que as metodologias vistas na prática seguem pouco a abordagem de Design Centrado no Usuário da Interação Humano-Computador.

Também não existe uma separação clara da fase de Especificação daquela que a antecede. Nessa fase o arquiteto de informação continua a ser o principal ator, mas conta com o auxílio das áreas de projeto gráfico e tecnologia de informação. Foi observado que 
na prática são produzidos os mesmos documentos vistos na investigação teórica: o sitegrama, o fluxo de navegação e os wireframes.

Existe pouca preocupação com a fase de Implementação, como ocorre com as metodologias analisadas na investigação teórica. Isso pode ocasionar websites que são implementados sem seguirem corretamente as especificações do arquiteto de informação.

Também existe pouca preocupação com a fase de Avaliação, confirmando a investigação teórica. Quando existe essa fase, ela fica inteiramente a cargo da empresa contratante e raramente o arquiteto tem acesso aos relatórios de avaliação. Falta uma posição pró-ativa dos arquitetos de informação em solicitar avaliações aos seus contratantes.

Com relação às dificuldades levantadas na segunda pesquisa de campo, foi observado que a maioria delas tem em comum o foco o contratante e ocorrem mais na fase de Concepção.

$\mathrm{Na}$ fase de Pesquisa três dificuldades foram apontadas: definir o objetivo do website, obter acesso as fontes de informação e produzir um documento conciso expondo os pontos negativos do website do contratante sem gerar antipatias. Para superá-las, o arquiteto emprega sua criatividade, iniciativa e o domínio de técnicas de apresentação. Ele também pode participar do planejamento estratégico do website, embora não seja sua atribuição e não tenha todas as habilidades necessárias.

Já na fase de Concepção foram apontadas quatro dificuldades distintas: integrar o website com sistemas legados, evitar usar no website a linguagem e a organização interna do contratante, atender a públicos-alvos diferentes e atender vários decisores. Para superálas o arquiteto realiza pesquisa de boas práticas e referências, estudos de cenário, análises heurística, testes de usabilidade, envolve a área de tecnologia de informação e o contratante com o projeto, negocia e tem uma atitude de humildade perante os demais membros do time de projeto.

Por fim na fase de Especificação apenas duas dificuldades foram apontadas: fazer o contratante compreender os documentos de especificação e gerenciar um volume grande 
desses documentos. Para superar a primeira dificuldade, o arquiteto precisa sensibilizar o seu leitor ou criar uma linguagem para ele. Já a segunda dificuldade ainda não é totalmente superada. Falta para o arquiteto de informação ferramentas de software, especialmente ferramentas CASE, que automatizem a produção e o gerenciamento dos seus documentos.

Com relação as estratégias temos que para as dificuldades com foco no contratante a negociação e o envolvimento do contratante são as mais adotadas com bastante sucesso. Nas dificuldades com foco no próprio trabalho de arquitetura de informação as estratégias evidenciaram diversas habilidades necessárias aos arquitetos de informação: paciência, determinação, habilidade em apresentar o seu trabalho, criatividade e iniciativa. Por fim nas dificuldades com foco no contexto tecnológico, as estratégias se basearam na pesquisa de soluções e na negociação com a área de tecnologia de informação, porém não foram completamente eficientes.

De forma geral, ainda não existe por parte dos contratante uma compreensão da metodologia de projetos de arquitetura de informação e da importância de cada atividade. Com isso atividades essenciais são suprimidas ou não é dado o prazo adequado para executá-las. Os testes de usabilidade são as atividades mais sacrificadas. Resta aos arquitetos de informação usar sua criatividade, iniciativa e habilidade de negociação para conseguir produzir websites de qualidade.

As metodologias de projetos de Arquitetura de Informação precisam evoluir e realmente adotar abordagens de Design Centrado no Usuário para alcançarem o objetivo a que se propõem: satisfazer às necessidades de informação dos usuários. Na adoção da abordagem da Interação Humano-Computador é preciso melhorar o domínio das técnicas mais adequadas à Arquitetura de Informação e conscientizar os contratantes da importância de utilizá-las. Já para adotar a abordagem da Ciência da Informação é preciso pesquisar formas de aplicar seus fundamentos e métodos na fase de Pesquisa, porque nesse ponto a literatura se mostrou carente.

Também é preciso pesquisar técnicas de avaliação dos resultados dos projetos próprias da Arquitetura da Informação para que os arquitetos possam avaliar se seus projetos realmente conseguiram satisfazer às necessidades dos usuários. 
E para legitimar a Arquitetura de Informação enquanto profissão é preciso que aumente o interesse das instituições de ensino sobre o tema, de modo a que criem cursos para formar arquitetos de informação. A formação autodidata que esses profissionais têm adotado, devido a falta de alternativas, não tem se mostrado eficiente.

Crê-se que a importância desse trabalho não está apenas em consolidar e unificar as metodologias de projeto de arquitetura de informação de modo que essas possam evoluir e auxiliar na legitimação de uma nova profissão. A sua importância está em auxiliar na busca de uma forma de trabalho que permita aos arquitetos de informação realmente criarem websites centrados no usuário. 


\section{Referências}

As referências desse trabalho estão resumidas e disponíveis para consulta no website www.guilhermo.com.

ABDALLA, E. A seleção da metodologia da pesquisa por mestrandos em

Biblioteconomia e Ciência da Informação. São Paulo, 2003. Dissertação (Mestrado) Escola de Comunicações e Arte, Universidade de São Paulo.

ALMEIDA, R. ; OLIVEIRA, M. Mirando Resultados. São Paulo: Novatec, 2002.

ALONSO, J. ; MARTÍNEZ, L. Medios Interactivos: Caracterización y contenidos, In: NOCI, J. ; ALIAGA, R. Manual de Radacion Ciperperiodista. Barcelona: Ariel, 2003, cap. 6, p. 261-305.

ANTUNES, L. O texto tridimensional. São Paulo, Dissertação (Mestrado), Escola de Comunicações e Artes, Universidade de São Paulo, 1998.

BARDIN, L. Análise de Conteúdo. Lisboa: Edições 70, 2000. p. 27-46, 93-150. 
BELTON, K. A Design Foundation for Information Architecture. In: MORROGH, E. Information Architecture: An Emerging 21st Century Profession. New Jersey: Prentice Hall, 2003, cap. 22, p. 143-153.

BRINCK, T.; GERGLE, D. ; WOOD, S. Usability for the Web: Designing web sites that work. San Francisco: Morgan Kaufmann, 2002.

BUSTAMANTE, A. Arquitectura de Información y usabilidad: nociones básicas para los professionales de la información, 2004. Disponível em: http://www.bvs.sld.cu/revistas/aci/vol12_6_04/aci04604.htm. Acesso em: 14 out 2005. CAMPO,M.; GOMES, H. ; MOTTA, D., Elaboração de Tesauro Documentário. Biti, 2004. Disponível em: http://www.conexaorio.com/biti/tesauro/. Acesso em: 4 jan 2005.

CASTELLS, M. Internet e sociedade em rede. In: MORAES, D. (Org.). Por uma outra comunicação. Rio de Janeiro: Record, 2003, p. 255-288.

CHEUK, B. ; DERVIN, B. A Qualitative Sense-Making Study of the information seeking situations faced by professionals in three workplace contexts. EJC/REC, v. 9, n. 2,3,4, 1999. Disponível em: http://communication.sbs.ohio-state.edu/sensemaking/art/artabscheukdervin99ejoc.html. Acesso em: 11 out 2005.

CHIOU, F. We are all connected: The path from Architecture to Information Architecture. Boxes and arrows, 2003. Disponível em: http://www.boxesandarrows.com/archives/we_are_all_connected_the_path_from_architec ture_to_information_architecture.php. Acesso em: 25 out 2005.

CNPQ. Diretório dos Grupos de Pesquisa no Brasil , 2006. Disponível em: http://dgp.cnpq.br/buscaoperacional/. Acesso em: 15 out 2006.

COPPER, A. About Face: The Essencials of User Interface Design. Foster City:IDG Books, 1995. 
COOPER, A. ; REIMANN, R. About Face 2.0: The Essencials of User Interface Design. Indianapolis:WILEY, 2003.

DEL NERO, H. O Sítio da Mente. São Paulo:Collegium Cognitio, 1997.

DERVIN, B. An overview of Sense-Making research: concepts, methods and results to date. In: International Communications Association Annual Meeting. Dallas, 1983.

DERVIN, B. From the Mind's Eye of the User: The Sense-Making QualitativeQuantitative Methodology. In: GLAZIER, J. ; POWELL, R. Qualitative Research in Information Management. Englewood: Libraries Unlimited, 1992. cap. 6, p. 61-84. Disponível em: http://communication.sbs.ohio-state.edu/sensemaking/art/artabsdervin92powell.html. Acesso em: 11 out 2005.

DERVIN, B. Chaos, Order, and Sense-Making: A proposed theory for information design. In JACOBSON, R. ed. Information Design. Cambridge: MIT Press, 1997. Disponível em: http://alexia.lis.uiuc.edu/gslis/allerton/95/dervin.draft.html. Acesso em: 22 out 2005.

DERVIN, B. ; NILAN, M. Information needs and uses. Annual Review of Information Science and Technology (ARIST). vol. 21, pp 3-33, New York: Knowledge Industry Publications, 1986.

DIJCK, P. Information Architecture for Designers. Hove:RotoVision, 2003.

DUBOIS, J. et al. Dicionário de Lingüística. Cultrix, 1993.

EDWARDS, D. ; HARDMAN, L. Lost in Hyperspace: cognitive mapping and navigation in a hypertext enviroment in Hypertext: theory into practice, Oxford:Intellect, 1993.

EWING, C.; MAGNUSON, E. ; SCHANG, S. Information Architecture Proposed Curriculum. www.gslis.utexas.edu, 2002. Disponível em: http://www.gslis.utexas.edu/ iag/resources/ia-curriculum-final.PDF. Acesso em: 18 jul 2005. 
FAST, K.; LEISE, F. ; STECKEL, M. Creating a Controlled Vocabulary. Boxes and Arrows, 2003. Disponível em:

http://www.boxesandarrows.com/archives/creating_a_controlled_vocabulary.php. Acesso em: 25 out 2005.

FELDMAN, S. ; SHERMAN, C. The high cost of not finding information. IDC, 2001. Disponível em:

http://www.kmworld.com/publications/magazine/index.cfm?action=readarticle\&Article_I $\mathrm{D}=1725 \&$ Publication_ID=108. Acesso em: 22 out 2005.

FERREIRA, S. Redes eletrônicas e necessidades de informação: Abordagem do Sense-Making para estudo de comportamento de usuários do Instituto de Física da USP. São Paulo, Tese (Doutorado), Escola de Comunicações e Artes, Universidade de São Paulo, 1995.

FERREIRA, S. Estudos de Necessidades de Informação: dos paradigmas tradicionais à abordagem Sense-Making, ABEBD, 1997. Disponível em:

http://www.eca.usp.br/nucleos/sense/textos/sumar.htm. Acesso em: 11 out 2005.

FLEMING, J. Web Navigation: Designing the User Experience. Sebastopol:O'Reilly, 1998.

FRASER, J. Taking a content inventory. New Architect, 2001. Disponível em: http://www.webtechniques.com/archives/2001/10/fraser/. Acesso em: 01 out 2004.

FRIEDMAN, K. Creating design knowledge: from research into practice. IDATER, 2000. Disponível em:

http://www.lboro.ac.uk/departments/cd/docs_dandt/idater/downloads00/Friedman2000.pdf. Acesso em: 13 out 2005.

FRIEDMAN, K. Theory construction in design research: criteria, approaches, and methods. Design Studies, v.24, p.507-522, 2003. Disponível em: http://w3.msi.vxu.se/ per/DVM752/Friedman.pdf. Acesso em: 13 out 2005. 
FUVEST (2006) Manual do Candidato FUVEST 2007 , 2006. Disponível em: http://www.fuvest.br/vest2007/manual/manual.stm. Acesso em: 17 dez 2007

GARCÍA, L. Interação Ser Humano-Computador: Marco Teórico e Implicações no Design de Interfaces-Usuários, 2003. Material didático.

GARCÍA, X. Retórica del Hipertexto Periodístico, In: Noci, J. ; Aliaga, R. Manual de Radacion Ciperperiodista. Barcelona: Ariel, 2003, cap. 9, p. 385-422.

GARRETT, J. A visual vocabulary for describing information architecture and interaction design. JJG.NET, 2002. Disponível em: http://www.jjg.net/ia/visvocab/ Acesso em: 25 out 2005

GARRETT, J. (b) The Psycology of Navigation. 2002. Disponível em: http://www.digital-web.com/articles/the_psychology_of_navigation/. Acesso em: 4 jan 2005.

GARRETT, J. Um vocabulário visual para AI e Design de Interação. Afifa, 2004. Disponível em: http://aifia.org/pt/translations/000332.html. Acesso em: 24 fev 2005.

GIL, A. Métodos e técnicas de pesquisa social. 5 ed. São Paulo: Atlas, 1999.

HAVERTY, M. Information Architecture without internal theory: An inductive design process. Journal of the American Society for Information Science and technology, v. 53 n. 10, p. $839-845,2002$.

HOOLEY, G. ; SAUNDERS, J. Posicionamento Competitivo, São Paulo:Makron, 1996.

HORTON, W. O Livro do Ícone. São Paulo:Berkeley, 1994.

IMMACOLATA, M. Pesquisa em comunicação. Loyola, 2003.

INFORMATION ARCHITECTURE INSTITUTE About Us. 2005. Disponível em: http://iainstitute.org/pg/about_us.php. Acesso em: 10 out 2005. 
INSTONE, K. Navigation Stress Test, 2003. Disponível em: http://userexperience.org/uefiles/navstress/. Acesso em: 4 jan 2005.

INSTONE, K. Location, Path \& Attribute Breadcrumbs. User-experience.org, 2004. Disponível em: http://user-experience.org/uefiles/breadcrumbs/. Acesso em: 26 abr 2005.

JACOB, E. ; SHAW, D. Sociocognitive Perspectives on Representation. Annual Review of Information Science and Technology (ARIST). v. 33, p. 131-185, New York: Knowledge Industry Publications, 1988.

KOTLER, P. Administração de Marketing. 5ed. São Paulo: Atlas, 1998.

LAKOFF, G. Women, Fire, and Dangerous Things. University Of Chicago Press, 1990.

LARA FILHO, D. O fio de Ariadne e a arquitetura da informação na WWW. DataGrama Zero, 2003, v.4, n.6, dez/03. Disponível em: http://www.dgzero.org/dez03/Art_02.htm. Acesso em: 4 jan 2005.

LARIÚ, N. Dicionário de Baianês. 2ed, São Paulo:Inovação, 1992.

LATHAM, D. Information Architecture: Notes toward a new curriculum. Journal of the American Society for Information Science and Technology, v. 53, n. 10, p. 824-830, 2002.

LIMA, G. Interfaces entre a ciência da informação e a ciência cognitiva. Ciência da Informação, v. 32, n. 1, p. 77-87, 2003.

LINE, M. Draft definitions: information and library needs, wants, demands and uses. ASLIB Proceedings, v.26, n.2, 1974.

MARCOS, J. El periodismo ante la tecnología hipertextual, In: Noci, J. ; Aliaga, R. Manual de Radacion Ciperperiodista. Barcelona: Ariel, 2003, cap. 5, p. 231-259. 


\section{MARCUS, A. Return on Investment for Usable User - Interface Design: Examples} and Statistics. AM+A, 2002. Disponível em:

http://www.amanda.com/resources/ROI/AMA_ROIWhitePaper_28Feb02.pdf. Acesso em: 13 jul 2005.

MARQUES, S. Interfaces Homem-Máquina: Interação ou Integração?. São Paulo, Monografia (Mestrado), Faculdade de Filosofia, Letras e Ciências Humanas, Universidade de São Paulo, 1995.

MARTINEZ, M. Um método de web design baseado em usabilidade. Tese (Doutorado), Escola Politécnica da Universidade de São Paulo, 2002.

MAURER, D. ; WARFEL, T. Card sorting: a definitive guide. Boxes and Arrows, 2004. Disponível em: http://www.boxesandarrows.com/archives/card_sorting_a_definitive_guide.php. Acesso em: 27 abr 2005.

McDOWELL, S. Visio Replacement? You Be the Judge. Boxesandarrows, 2006.

Disponível em: http://www. boxesandarrows. com/ view/ visio_replaceme. Acesso em: 16 jan 2007.

McKNIGHT, C; DILLON, A. ; RICHARDSON, J. Hypertext in Context. Cambridge University Press, 1991.

MELLY, M Como Projetar, 2003. Material didático. Disponível em: http://www.eca.usp.br/prof/mylene/grad/disciplinas/metodologia/metodologia.htm. Acesso em: 25 jan 2007.

MELLY, M.; FERREIRA, S.; GARCIA, M. ; REIS, G. Ciencias de la información y de la computación: uma visión integrada del diseño de sistemas virtuales de búsqueda directa de información centrados em el usuario. In: IV Coloquio Internacional de Ciencias de la Documentación y VI Congresso del Capítulo Español de ISKO, 2003.

MOLINARI, L. Testes de Software. São Paulo: Érica, 2003. 
MORGAD, L. Estilos de navegação no hipertexto: aspectos da construção do número na criança em Jean Piaget, 1994. Disponível em:

http://www.niee.ufrgs.br/ribie98/CONG_1994/VOLUME_II/C35/II_48_65.HTML.

Acesso em: 25 out 2005.

MORROGH, E. Information Architecture: An Emerging 21st Century Profession.

New Jersey: Prentice Hall, 2003.

MORVILLE, P. Bottoms Up, 2002. Disponível em:

http://www.newarchitectmag.com/documents/s=7733/na1202b/index.html. Acesso em: 12 nov 2004.

MORVILLE, P. Information Architecture Conference. Paris:Information Today, 2004. (palestra) Disponível em: http://www.infotoday.com/iaparis/programme.shtml. Acesso em: 18 mai 2005.

MORVILLE, P. O uso estratégico da Arquitetura de Informação, São Paulo:

TerraForum, 2005. (palestra). Disponível em:

http://www.semanticstudios.com/events/brazilia.ppt. Acesso em: 29 jan 2006.

NETCRAFT. Web Server Survey, 2005. Disponível em:

http://news.netcraft.com/archives/web_server_survey.html. Acesso em: 13 out 2005.

NIELSEN, J. Projetando Websites. Rio de Janeiro: Campus, 2000.

NIELSEN, J.; et al. E-Commerce User Experience. Fremont: Nielsen Norman Group, 2001.

NOCI, J. ; SALAVERRÍA, R. Hipertexto Periodístico: Teoría y Modelos, In: Noci, J. ; Aliaga, R. Manual de Radacion Ciperperiodista. Barcelona: Ariel, 2003, cap 2, p. 81139.

NORMAN, D. Cognitive Engineering In: User-Centered System Design: new perspectives on Human-Computer Interaction. Lawrence Erlbawn, 1986. 
NORMAN, D. Emotional Design: Why We Love (Or Hate) Everyday Things . New York: Basic Books, 2003.

OJAKAAR, E. ; SPOOL, J. Getting Them to What They Want. UIE, 2001. Disponível em: http://www.uie.com/reports/what_they_want/. Acesso em: 25 out 2005.

PORTER, M. Estratégia Competitiva. 18ed. Rio de Janeiro:Campus, 1986.

PRESSMAN, R. Engenharia de Software. São Paulo:MAKRON Books, 1995.

PROJECT MANAGEMENT INSTITUTE, Um guia do conjunto de conhecimentos em gerenciamento de projetos (Guia PMBOK). 2004.

REISS, E. Pratical Information Architecture. Addison-Wesley Professional, 2000.

ROSENFELD, L. More Diagrams from Jess and Me. LouisRosenfeld.com, 2001. Disponível em: http://louisrosenfeld.com/home/bloug_archive/000045.html. Acesso em: 17 jul 2005.

ROSENFELD, L. User Experience Education. LouisRosenfeld.com, 2005. Disponível em: http://louisrosenfeld.com/home/bloug_archive/000341.html. Acesso em: 17 jul 2005.

ROSENFELD, L. ; MORVILLE, P. Information Architecture for the Word Wide Web. 2ed. Sebastopol: O'Reilly, 2002.

ROSENFELD, L. ; MORVILLE, P. Information Architecture for the Word Wide Web. 3ed. Sebastopol: O'Reilly, 2006.

ROSENFELD, L. ; MORVILlE, P. (b) Polar Bear Book, Third Edition, Survey 3: Software for IA. Information Architecture Institute, 2006. Disponível em: http://iainstitute.org/documents/research/results/polar_bear_survey_3.html. Acesso em: 22 jan 2007. 
SATO, F. ; HASHIMOTO, M. Excesso de Informação. Informação, Comunicação e a Sociedade do Conhecimento, 2004. Disponível em:

http://conhecimento.incubadora.fapesp.br/portal/trabalhos/2004/ExcessoDeInformacao. Acesso em: 08 jan 2007.

SAUSSURE, F. Curso de lingüística geral. Cultrix, cap. 1 e 2, 1995.

SEYBOLD, P. Clientes.com. Makron, 2000.

SHIPLE, J. Information Architecture Tutorial. Webmonkey, 2000. Disponível em: http://webmonkey.wired.com/webmonkey/design/tutorials/tutorial1.html. Acesso em: 29 jan 2005.

SILVA, J.; FERREIRA, M. ; BORGES, M. Análise metodológica dos estudos de necessidades de informação sobre setores industriais brasileiros: proposições. Ci. Inf. Brasília, v. 31, n. 2, p. 129-41, maio/agosto, 2002. Disponível em: http://www.ibict.br/cienciadainformacao/include/getdoc.php?id=489\&article=201\&mode= pdf. Acesso em: 11 out 2005.

SNYDER, C. Paper Prototyping: The fast and easy way to design and refine user interfaces. Morgan Kaufmann, 2003.

SOUZA, R. Get ROI from Design. FORRESTER, 2001. Disponível em: http://www.forrester.com/ER/Research/Report/Summary/0,1338,11180,00.html. Acesso em: 13 out 2005.

TAYLOR, A. The Organization of information. Englewood: Libraries Unlimited, 1999.

TOUB, S. Evaluating Information Architecture: A practical guide to assessing web site organization. ACIA, 2000. Disponível em: http://argusacia.com/white_papers/evaluating_ia.pdf. Acesso em: 4 jan 2005. 
UNIVERSITY OF CALIFORNIA AT BERKELEY, How Much Information ? 2003. 2003. Disponível em: http://www.sims.berkeley.edu/research/projects/how-much-info2003/index.htm. Acesso em: 16 jan 2005.

USABILITY NET International standards for HCI and usability, 2003. Disponível em: http://www.hostserver150.com/usabilit/tools/r_international.htm. Acesso em: 11 out 2005.

VIVINDECE RESEARCH, A Tangled Web. E-Tailer's Digest, 2001. Disponível em: http://www.etailersdigest.com/resources/Specials/Tangled_Web.htm. Acesso em: 16 jan 2005.

WEST, A. The Art of Information Architecture. iBoost, 1999. Disponível em: http://www.iboost.com/build/backend/arch/644.htm. Acesso em: 29 jan 2005.

WILSON, T. Recent trends in user studies: action research and qualitative methods, Information Research, v. 5, n. 3, abril, 2000. Disponível em: http://informationr.net/ir/53/paper76.html. Acesso em: 11 out 2005.

WITHROW, J. Cognitive Psycology \& IA: From Theory to Practice. Boxes and Arrows, 2003. Disponível em:

http://www.boxesandarrows.com/archives/cognitive_psychology_ia_from_theory_to_prac tice.php Acesso em: 25 out 2005.

WURMAN, R. Ansiedade de Informação. São Paulo: Cultura, 1991.

WURMAN, R. Information Architects. New York: Graphis, 1997.

WODTKE, C. Information Architecture: Blueprints for the web. Indianapolis: New Riders, 2003.

YOURDON, E. Análise Estruturada Moderna. Campus, 1990. 


\section{Anexo I Questionário da pesquisa on-line}

A seguir estão apresentados a carta convite, enviada por e-mail e o questionário on-line utilizado na pesquisa de levantamento do perfil do arquiteto de informação das listas de discussão brasileiras.

\section{- Carta convite}

Prezado(a) Sr.(a)

Venho convidá-lo(a) a participar da pesquisa acadêmica que estou desenvolvendo como parte do meu mestrado em Ciência da Informação na ECA/USP, sob orientação da Profa. Dra. Sueli Mara S. P. Ferreira, e que tem como objetivo conhecer o perfil e as experiências vividas pelos profissionais brasileiros que trabalham com Arquitetura de Informação.

Para tanto elaborei um questionário eletrônico, com tempo estimado de preenchimento de 10 minutos. Para participar, basta clicar acessar o endereço www.guilhermo.com/questionario

As respostas serão mantidas em anonimato e utilizadas apenas para a pesquisa em foco.

Os participantes serão comunicados quando os resultados forem divulgados e receberão acesso a uma versão eletrônica do mesmo

Desde já agradeço a sua participação.

Abraços, 


\section{- Questionário}

Esse questionário foi disponibilizado na URL www.guilhermo.com/questionario. Ao acessar essa URL, era apresentada ao usuário uma página com as instruções de preenchimento e duas páginas com as perguntas. Na primeira página estavam as perguntas destinadas a todos os entrevistados e na segunda página estavam as perguntas exclusivas aos profissionais. Essas páginas estão apresentadas a seguir juntamente com os comentários das perguntas.

Figura 14 - Questionário on-line - Instruções para o preenchimento

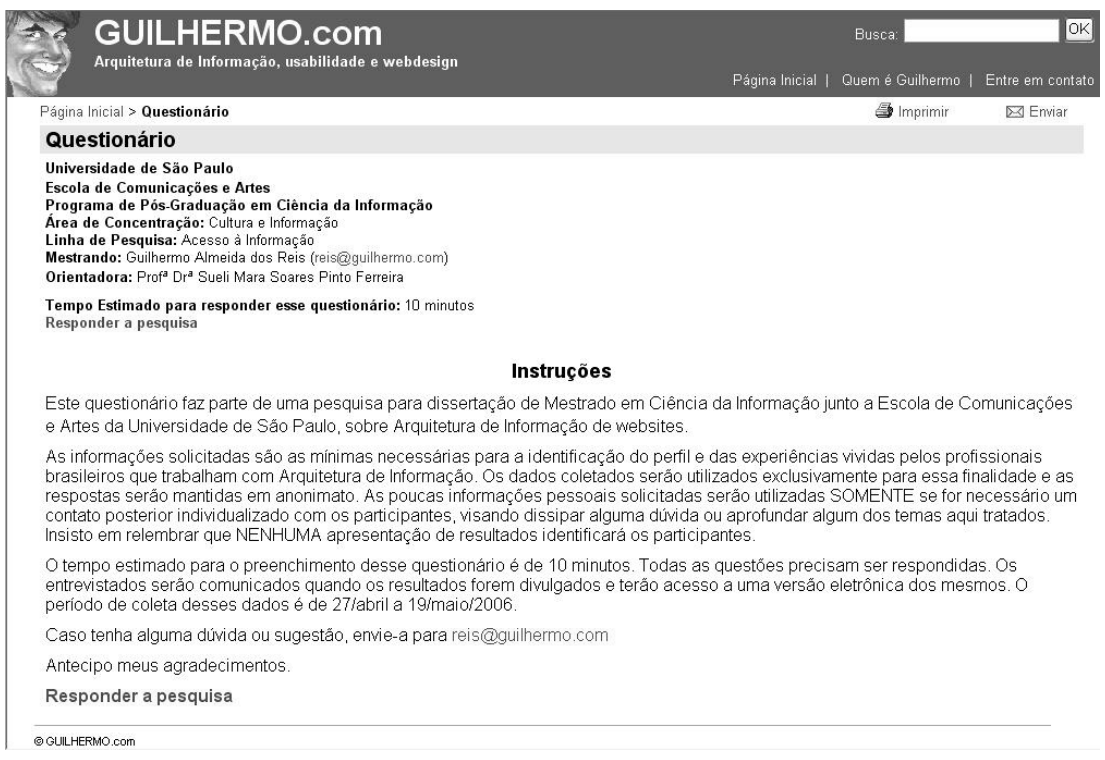

Figura 15 - Questionário on-line - Perguntas comuns a todos os entrevistados

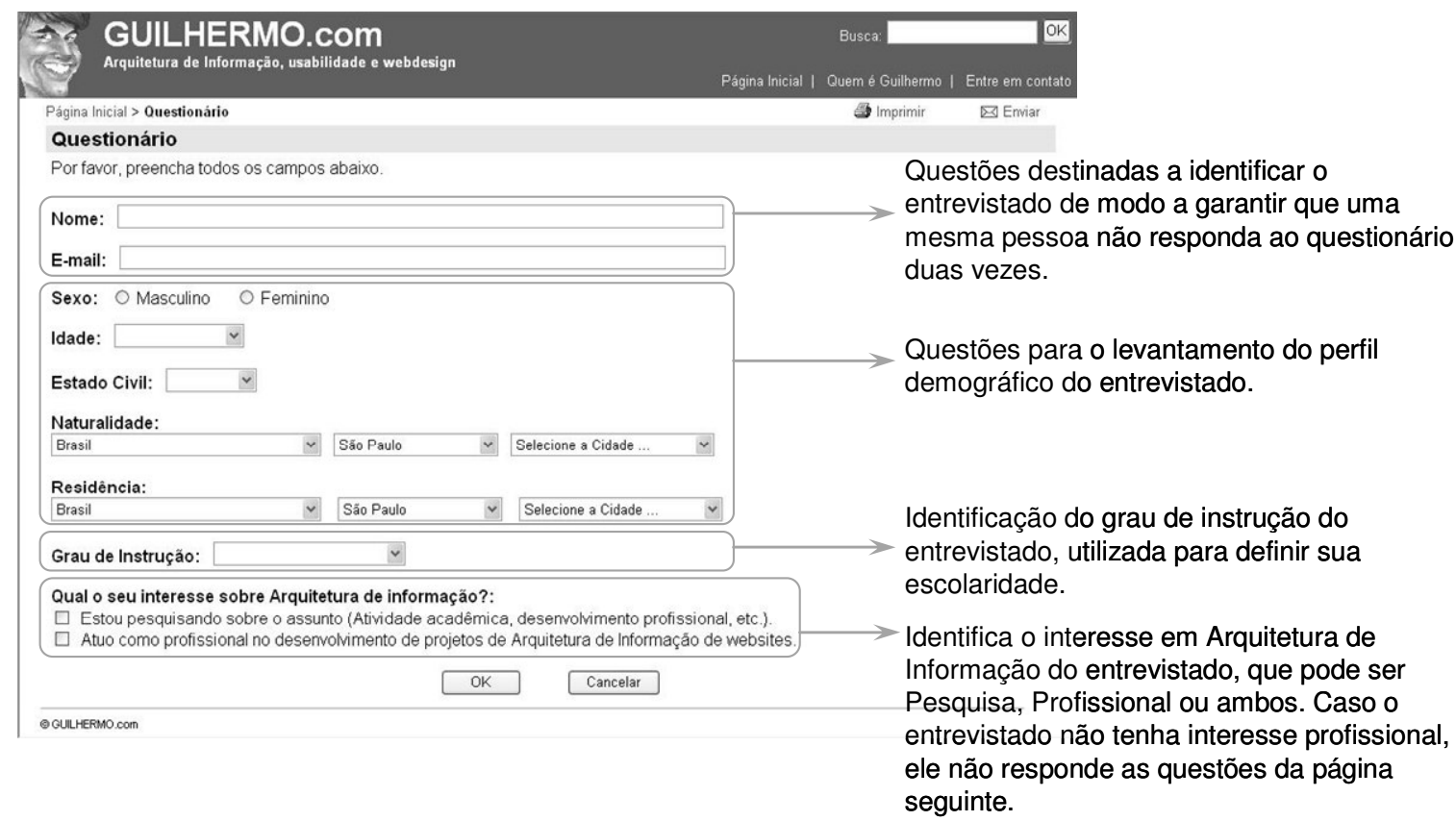


Figura 16 - Questionário on-line - Perguntas exclusivas aos profissionais

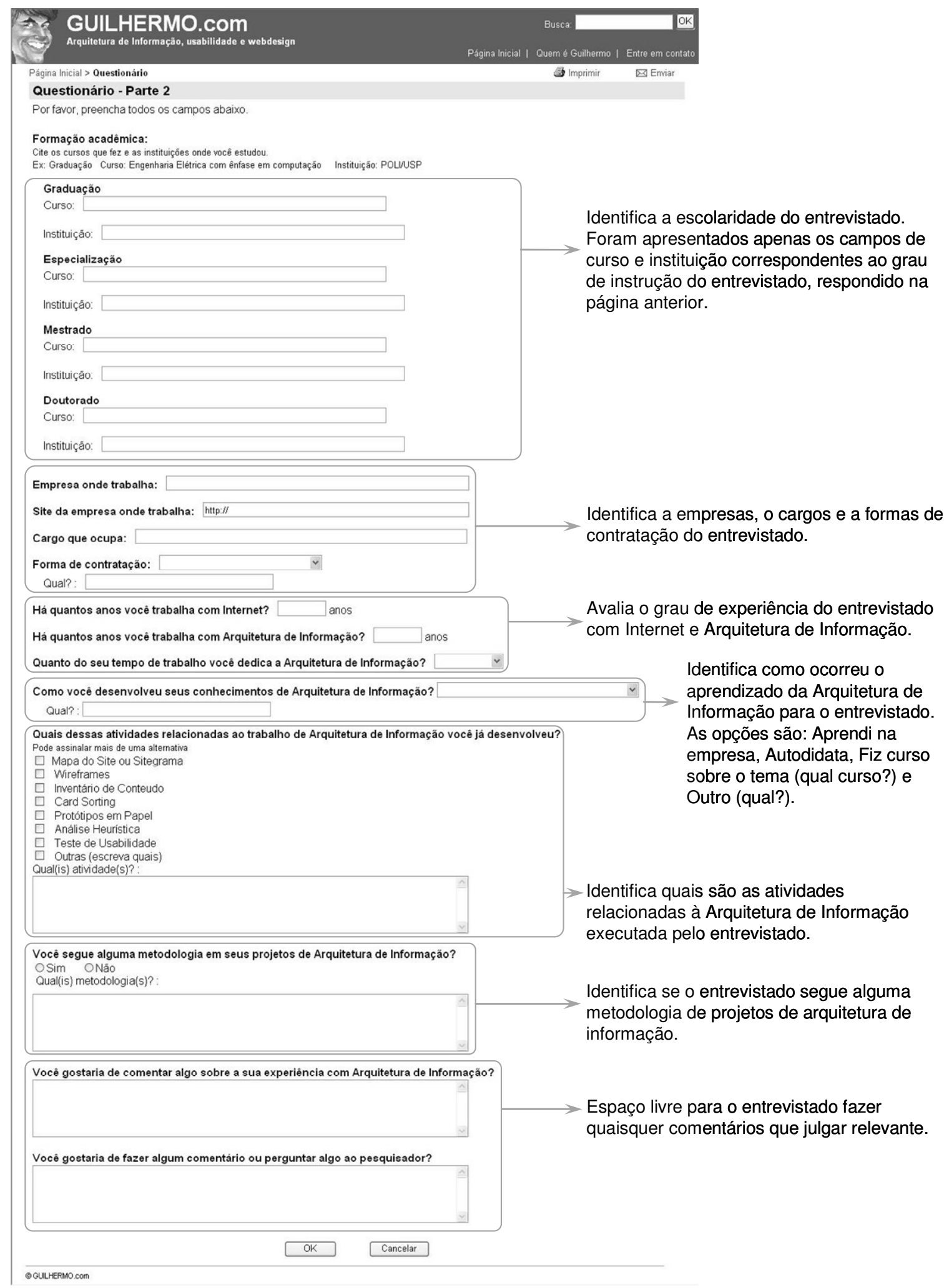




\section{Anexo II Roteiro da entrevista individual}

Para a pesquisa de levantamento das dificuldades, técnica e metodologias encontradas em projetos de arquitetura de informação de websites foi elaborado o roteiro de entrevista apresentado abaixo.

\section{Instruções}

Primeiro gostaria de agradecê-lo(a) por participar dessa pesquisa e dedicar o seu tempo. Como eu lhe disse no convite, eu estou fazendo uma pesquisa sobre a forma de trabalho dos arquitetos de informação no Brasil. Para isso vou entrevistar alguns profissionais com o intuito de detalhar como vocês trabalham.

Tudo que você disser vai ser usado apenas para essa pesquisa. Nos relatórios finais você não vai ser identificado, nem qualquer projeto ou pessoa que você citar. Por isso, quero que você se sinta bem à vontade para comentar tudo que quiser.

Eu estou filmando apenas para facilitar as minhas anotações. Essa fita e a sua imagem não serão divulgadas sem a sua autorização.

Vamos começar. 


\section{Identificação do entrevistado}

1. Nome:

2. Empresa onde trabalha:

3. Cargo:

4. Grau de Instrução:

5. Há quantos anos você trabalha com Arquitetura de Informação. Como foi que você começou a trabalhar nessa área? Conte resumidamente a sua história.

6. Como você aprendeu Arquitetura de Informação?

\section{Fase I - Levantamento da metodologia}

7. O que você faz exatamente na sua empresa? Quais são as suas responsabilidades?

8. Quais são as atividades que compõem um projeto de arquitetura de informação na sua empresa?

9. Eu escrevi cada uma dessas atividades em um cartão. Por favor, coloque-as na seqüência que vocês costumam executá-la em um projeto de arquitetura de informação na sua empresa.

10. [Se a quantidade de atividades for grande (maior que 15)] Agora, por favor, agrupe essas atividades em etapas. Você consegue dividir todas essas atividades nas etapas de um projeto?

11. Qual é o nome de cada uma dessas etapas?

12. Essa divisão em etapas existe na sua empresa? 
( ) Sim ( ) Não

13. Você concorda com essa seqüência de atividades e etapas? Por quê?

( ) Sim ( ) Não

14. Existe na sua empresa alguma documentação dessas atividades e etapas? Algum manual de processos e procedimentos?

( ) Sim ( ) Não

15. Existe alguma atividade relativa à Arquitetura de Informação que vocês não fazem na sua empresa e você acha que deveriam fazer?

\section{Fase II - Análise das dificuldades de um projeto}

16. Quantos projetos na sua empresa seguem todas essas etapas?

17. Por que alguns projetos não seguem todas essas etapas?

18. Você tem um projeto em que você participou e que seguiu todas essas etapas? Qual era esse projeto? Comente um pouco o que foi esse projeto.

19. Quais foram as grandes dificuldades desse projeto em cada uma dessas etapas?

20. De todas essas dificuldades, quais foram as 3 dificuldades mais impactantes para o sucesso do projeto?

\section{[Para cada dificuldade]}

21. Descreva essa dificuldade na forma de uma pergunta. Qual era pergunta que você tinha que responder por causa dessa dificuldade? Qual era a pergunta que essa dificuldade gerava? 
22. Por que você teve essa dificuldade?

23. Por que superar essa dificuldade era importante no projeto?

24. Você conseguiu superar essa dificuldade?

( ) Totalmente ( ) Parcialmente ( ) Não conseguiu

25. Por que essa resposta?

26. [Se superou a dificuldade totalmente] Como você superou essa dificuldade? [Se não superou a dificuldade] Mas você conseguiu superar essa dificuldade de alguma forma? Conseguiu contornar o problema?

27. [Se superou a dificuldade totalmente ou parcialmente] Como vocês conseguiram chegar nessa solução?

28. [Se superou a dificuldade parcialmente] Por que você não conseguiu superar a dificuldade totalmente?

29. Você ficou satisfeito com a solução?

( ) Totalmente satisfeito ( ) Parcialmente satisfeito ( ) Insatisfeito

30. Por que essa resposta?

31. E o cliente do projeto, ele ficou satisfeito com a solução?

( ) Totalmente satisfeito ( ) Parcialmente satisfeito ( ) Insatisfeito

32. Por que essa resposta?

33. O que te ajudou a superar essa dificuldade? 
34. Se você pudesse fazer um pedido a um gênio da lâmpada de Aladim, que pedido você faria superar essa dificuldade?

\section{Levantamento das facilidades}

35. Quais foram as facilidades que você teve nesse projeto?

36. Como essas facilidades te ajudaram?

\section{Fase III - Comparação da metodologia do entrevistado com o modelo teórico proposto (perguntas estimuladas)}

37. Na sua empresa vocês tem uma etapa de Análise/Pesquisa nos projetos de arquitetura de informação? Existe uma etapa onde vocês pesquisam os usuários, suas necessidades, a empresa e definem o escopo e requisitos do projeto.

( ) $\operatorname{Sim}($ ) Não

Qual é essa etapa?

38. Na sua empresa vocês não tem uma etapa de Concepção nos projetos de arquitetura de informação? Existe uma etapa onde vocês definem as linhas gerais da solução, onde vocês definem as regras dos sistemas de organização, de navegação, de rotulação e de busca. Qual é essa etapa?

( ) Sim ( ) Não

Qual é essa etapa?

39. Na sua empresa vocês tem uma etapa de Especificação nos projetos de arquitetura de informação? Existe uma etapa onde vocês detalham e documentam como o site deve ser implementado, onde vocês geram os documentos de Arquitetura de Informação?

( ) Sim ( ) Não 
Qual é essa etapa?

40. Na sua empresa vocês tem uma etapa de Implementação nos projetos de arquitetura de informação? Existe uma etapa onde vocês acompanham o trabalho de implementação do site feito por outras áreas?

( ) $\operatorname{Sim}($ ) Não

Qual é essa etapa?

41. Na sua empresa vocês tem uma etapa de Avaliação nos projetos de arquitetura de informação? Existe uma etapa onde vocês avaliam os resultados do projeto?

( ) $\operatorname{Sim}($ ) Não

Qual é essa etapa?

42. Vocês fazem pesquisas com usuários?

Quais?

Por que a resposta?

\section{Considerações finais}

Você tem mais algum comentário que gostaria de fazer? 